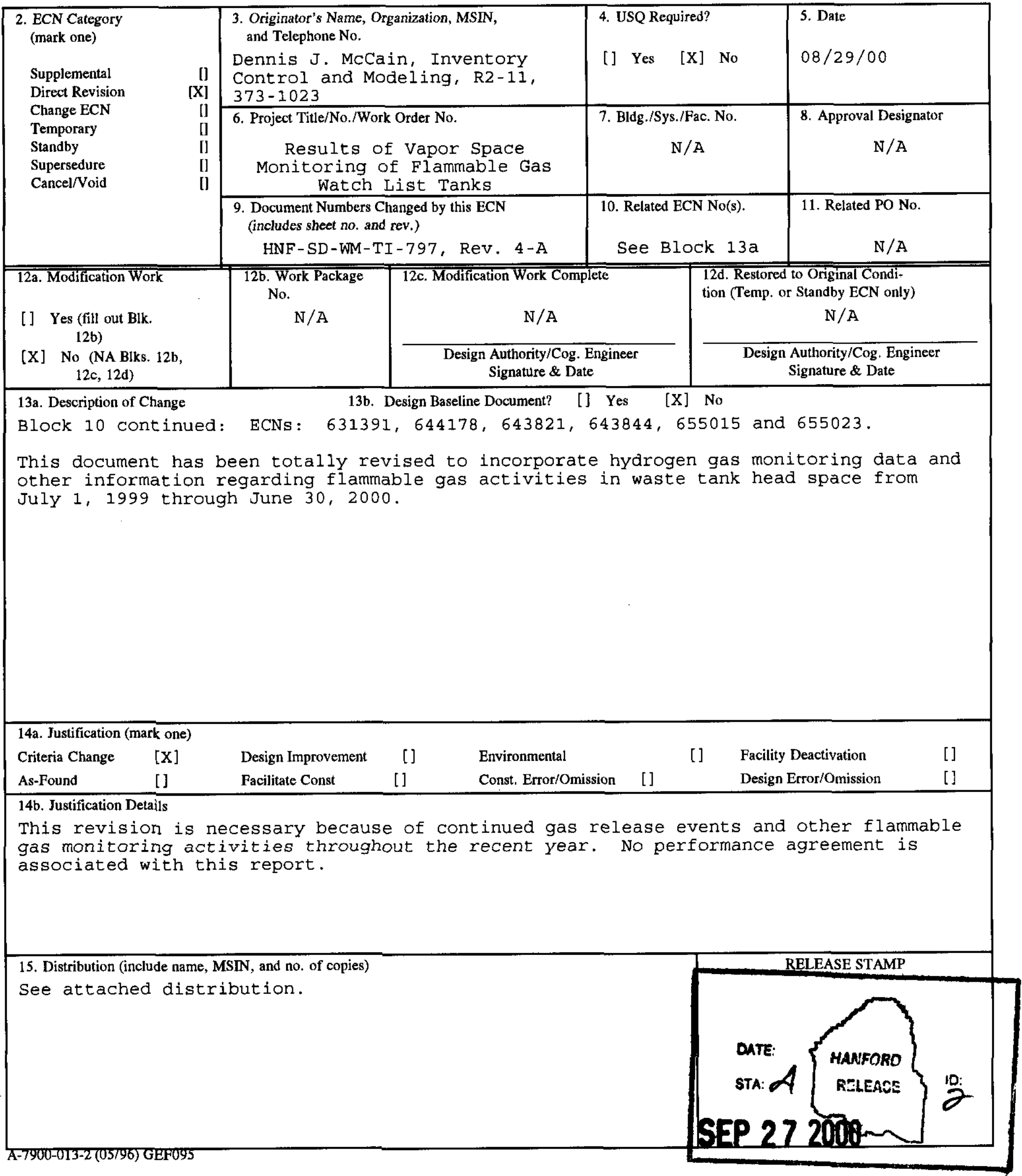




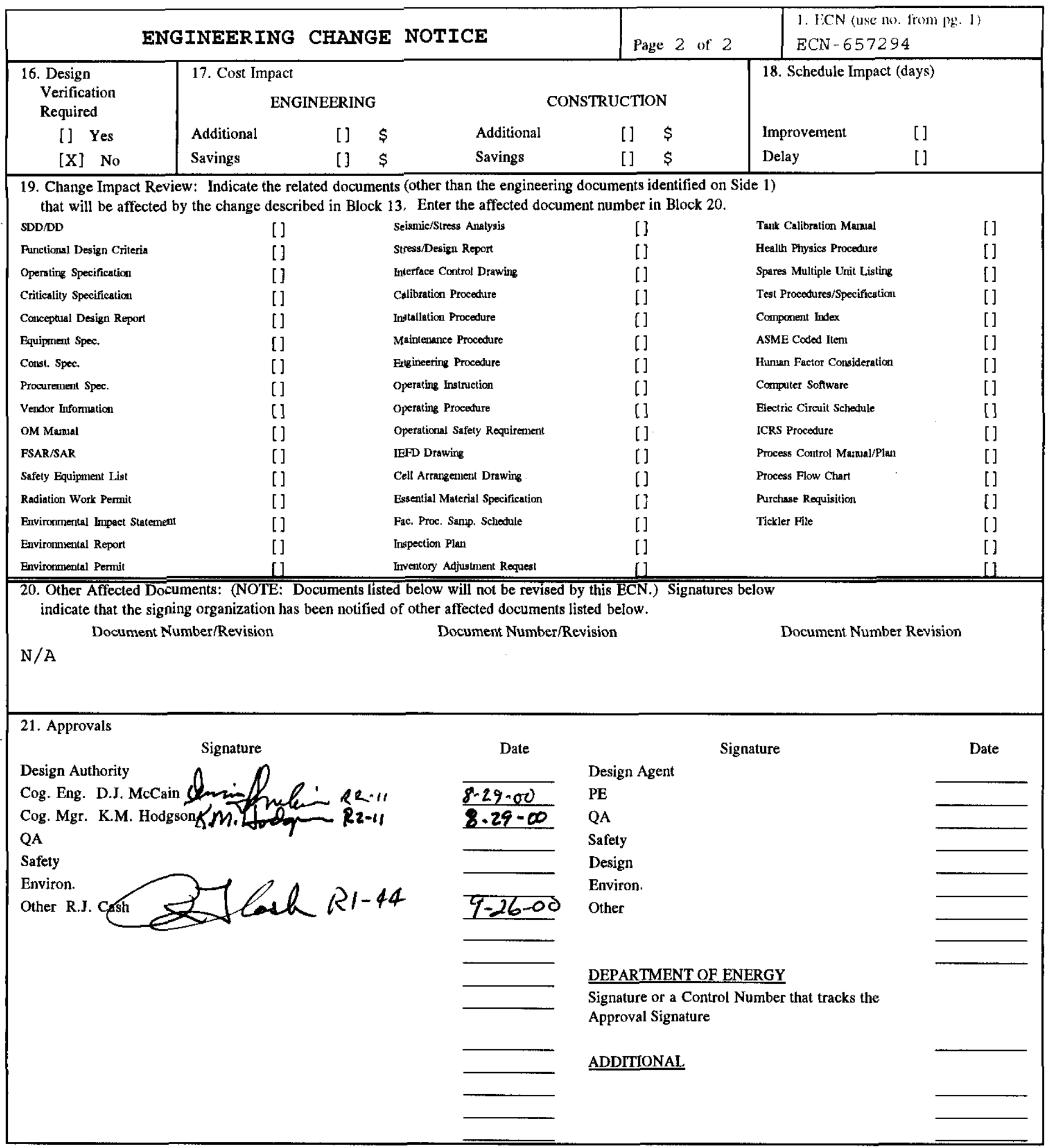




\section{DISTRIBUTION SHEET}

\begin{tabular}{|c|c|c|c|c|c|}
\hline \multirow[b]{2}{*}{ D1str: } & \multirow{2}{*}{\multicolumn{3}{|c|}{ From }} & \multicolumn{2}{|l|}{ Page 1 of 1} \\
\hline & & & & Date & $08 / 29 / 00$ \\
\hline \multicolumn{4}{|c|}{ Project Title/Work Order } & \multicolumn{2}{|c|}{ EDT No. N/A } \\
\hline \multicolumn{4}{|c|}{$\begin{array}{l}\text { HNF-SD-WM-TI-797, Rev. 5, "Results of Vapor Space Monitoring of } \\
\text { Flammable Gas Watch List Tanks" }\end{array}$} & \multicolumn{2}{|c|}{ ECN No. ECN-657294 } \\
\hline Name & MSIN & $\begin{array}{c}\text { Text } \\
\text { With } \\
\text { All } \\
\text { Attach. }\end{array}$ & Text only & $\begin{array}{l}\text { Attach./ } \\
\text { Appendix } \\
\text { Only }\end{array}$ & $\begin{array}{l}\text { EDT/ECN } \\
\text { Only }\end{array}$ \\
\hline
\end{tabular}

ON SITE

CH2M HILL Hanford Group

D. I. Allen

D. G. Balde

S. A. Barker

R. J. Cash

M. F. Erhart

K. D. Fowler

M. D. Hasty

K. M. Hodgson

T. A. Hu

G. D. Johnson

C. E. Leach

D. J. McCain

J. G. Propson

R. L. Schlosser

J. J. Zach

T.C.S.R.C.

\begin{tabular}{|c|}
\hline $\begin{array}{l}R 2-50 \\
S 5-05 \\
R 1-44 \\
S 7-73 \\
S 7-70 \\
R 2-11 \\
S 7-01 \\
R 2-11 \\
R 2-11 \\
\text { H4 - } 02 \\
R 1-44 \\
R 2-11 \\
R 1-43 \\
R 3-47 \\
R 1-49 \\
R 1-10\end{array}$ \\
\hline
\end{tabular}

Lockheed Martin Services, Inc.

Central Files

B1-07

$\mathbf{x}$

MACTEC

M. A. Kufahl

R2-11 $X$

Office of River Protection

C. A. Groendyke

H6- 60

J. S. Shuen

H6-60 $x$

Paciflc Northwest National Laboratory

J. W. Brothers

J. M. Cuta

J. L. Huckaby

I. A. Mahoney

P. A. Meyer

C. W. Stewart

K9-20 $\quad \mathrm{x}$

K7 -15

K7-15

K7-15

K7-15

K7-15 


\title{
Results of Vapor Space Monitoring of Flammable Gas Watch List Tanks
}

\author{
Dennis J. McCa1n \\ CH2M Hill Hanford Group, InC., Richland, WA 99352 \\ U.S. Department of Energy Contract 8023764-9-K001 \\ $\begin{array}{lll}\text { EDT } / E C N: & \text { ECN }-657294 & \text { UC: } 2070 \\ \text { Org Code: } & 74 \mathrm{~B} 40 & \text { CACN/COA: 101899/BA10 } \\ \text { B\&R Code: } & \text { EW } 3120074 & \text { Total Pages: /73 }\end{array}$
}

Key Words: Gas Release Event, Standard Hydrogen Monitoring System, Gas Characterization System, Vapor Grab Samples, Flammable. Gas Composition, Single-Shell Tank Ventilation Rates

Abstract: This report documents the measurement of headspace gas concentrations and monitoring results from the Hanford tanks that have continuous flammable gas monitoring. The systems used to monitor the tanks are standard Hydrogen Monitoring Systems. Further characterization of the tank off-gases was done with Gas Characterization systems and vapor grab samples. The background concentrations of all tanks are below the action level of $6250 \mathrm{ppm}$. Other information which can be derived from the measurements (such as generation rate, released rate, and ventilation ratel is also discussed.

SUMMA is a trademark of Molectrics, InC.

Whittaker is a trademark of Whittaker Corporation

TRADEMARK DISCLAIMER. Reference herein to any specific commercial product, process, or service by trade name, trademark, manufacturer, or otherwise, does not necessarily constitute or imply its endorsement, recommendation, or favoring by the United States Government or any agency thereof or its contractors or subcontractors.

Printed in the United States of America. To obtain copies of this document, contact: WHC/BCS Document Control Services, P.O. Box 1970, Mailstop H6-08, Richland WA 99352, Phone (509) 372-2420; Fax (509) 376-4989.
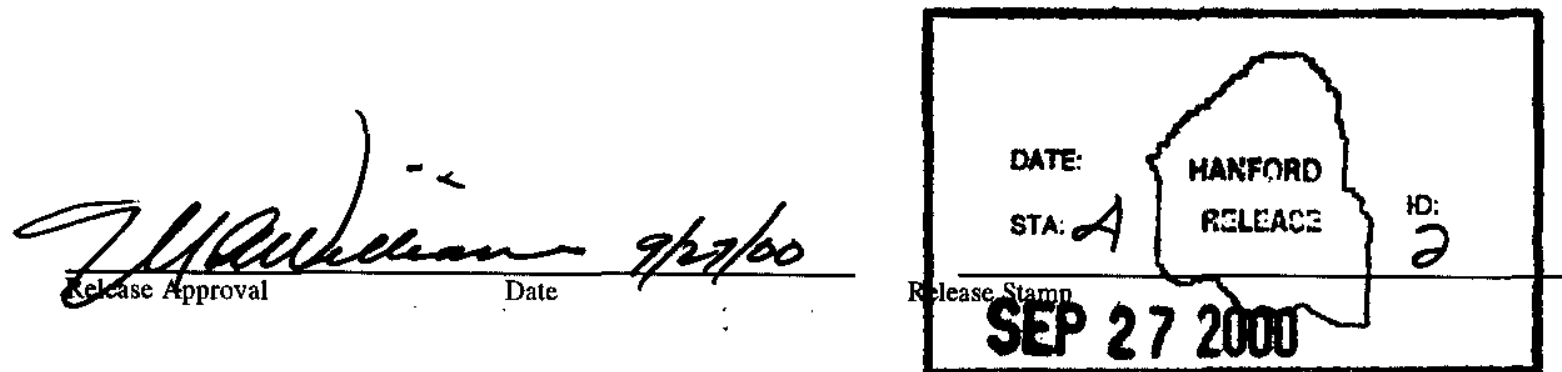

Approved for Public Release 


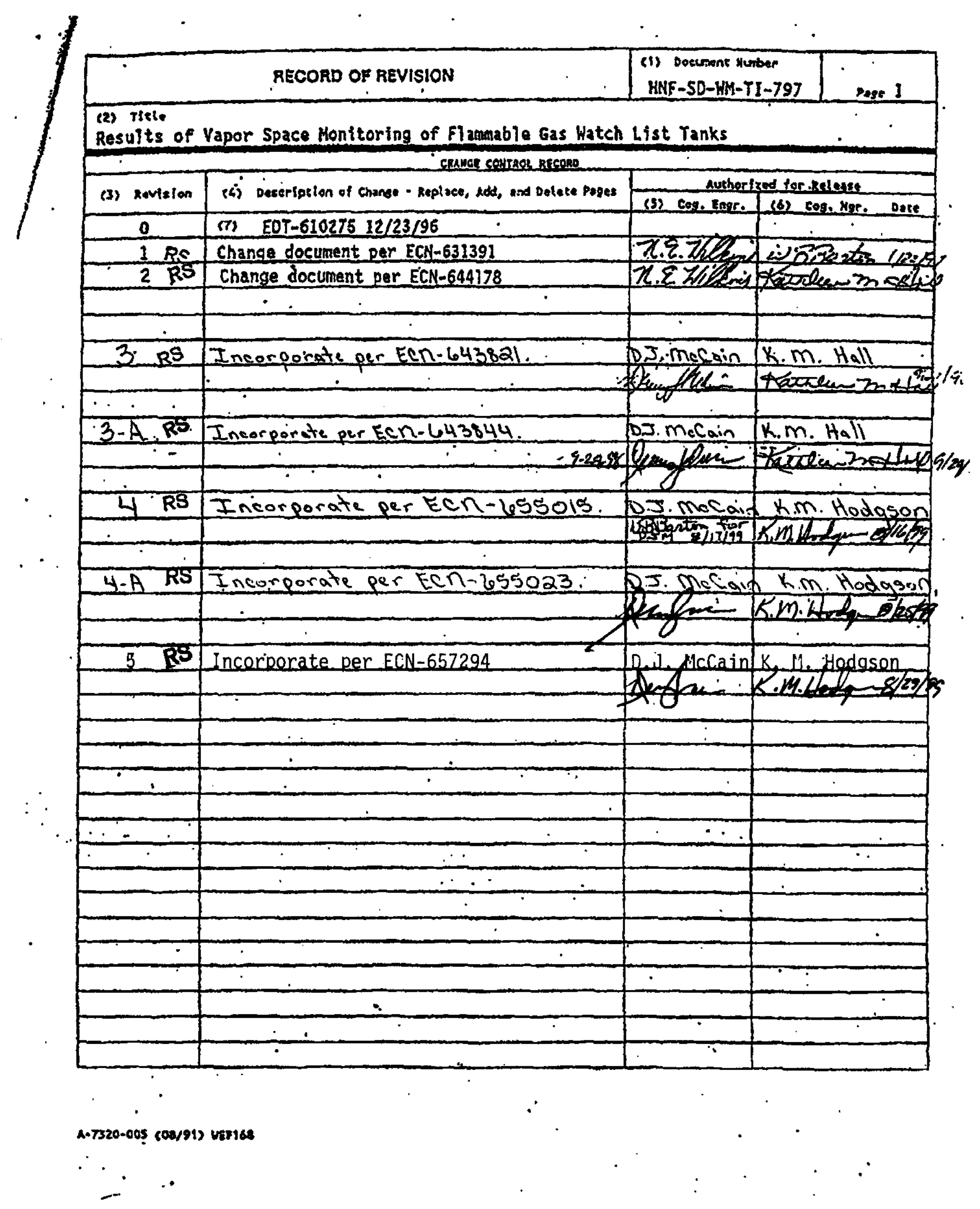




\section{Results of Vapor Space Monitoring of Flammable Gas Watch List Tanks}

Prepared for the U.S. Department of Energy

Assistant Secretary for Environmental Management

\section{CH2MHILL}

Hanford Group, Inc.

Richland, Washington

Contractor for the U.S. Department of Energy

Office of River Protection under Contract DE-AC06-99RL14047

Approved for Public Release; Further Dissemination Unlimited 


\section{Results of Vapor Space Monitoring of Flammable Gas Watch List Tanks}

D. J. McCain

CH2M HILL Hanford Group, Inc.

Date Published

September 2000

Prepared for the U.S. Department of Energy

Assistant Secretary for Environmental Management

\section{CH2MHILL \\ Hanford Group, Inc.}

P. O. Box 1500

Richland, Washington

Contractor for the U.S. Department of Energy

Office of River Protection under Contract DE-AC06-99RL14047

Approved for Public Release; Further Dissemination Unlimited 
LEGAL DISCLAIMER

This report was prepared as an account of work sponsored by an agency of the United States Government. Neither the United States Government nor any agency thereof, nor any of their employees, nor any of their contractors, subcontractors or their employees, makes any warranty, express or implied, or assumes any legal liability or responsibility for the accuracy, completeness, or any third party's use or the results of such use of any information, apparatus, product, or process disclosed, or represents that its use would not infringe privately owned rights. Reference herein to any specific commercial product, process, or service by trade name, trademark, manufacturer, or otherwise, does not necessarily constitute or imply its endorsement, recommendation, or favoring by the United States Government or any agency thereof or its contractors or subcontractors. The views and opinions of authors expressed herein do not necessarily state or reflect those of the United States Government or any agency thereof.

This report has been reproduced from the best available copy.

Available in paper copy and microfiche.

Available electronically at http://www.doe.gov/bridge. Available for a processing fee to the U.S. Department of Energy and its contractors, in paper, from:

U.S. Department of Energy

Office of Scientific and Technical Information P.O. Box 62

Oak Ridge, TN 37831-0062

phone: 865-576-8401

fax: 865-576-5728

email: reports@adonis.osti.gov(423) 576-8401

Available for sale to the public, in paper, from:

U.S. Department of Commerce

National Technical Information Service

5285 Port Royal Road

Springfield, VA 22161

Phone: 800-553-6847

fax: 703-605-6900

email: orders@ntis.fedworld.gov

online ordering:

http://www.ntis.gov/ordering.htm 


\section{CONTENTS}

1.0 INTRODUCTION.

1.1 PUBLIC LAW 101-510, SECTION 3137, AND THE FLAMMABLE GAS TANK WATCH LIST.

2.0 DESCRIPTION OF THE FLAMMABLE GAS MONITORING SYSTEMS ...............2-1

2.1 STANDARD HYDROGEN MONITORING SYSTEMS ....................................2-2

2.2 OTHER MONITORING SYSTEMS ................................................................2-3

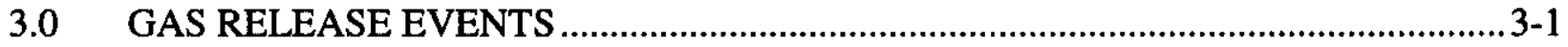

2.1 241-SY-101 GAS RELEASE EVENTS ...................................................

3.2 GAS RELEASE EVENTS FROM OTHER DOUBLE-SHELL TANKS ............3-3

3.3 GAS RELEASE EVENTS FROM SINGLE-SHELL TANKS ...........................3-8

3.4 SALTWELL PUMPING EFFECTS ON HYDROGEN CONCENTRATION.3-20 3.4.1 Hydrogen Gas Behavior in Response to Saltwell Pumping Activity.....3-20

3.4.2 Pump Pit Monitor Redundancy to SHMS Instrumentation.....................3-20

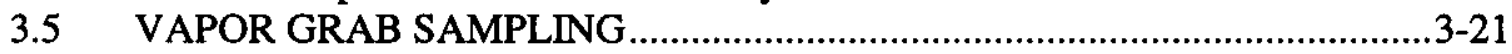

3.6 SUMMARY OF SHMS MONITORING ………........................................... 3-21

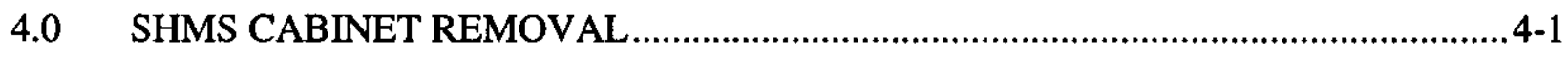

5.0 SUMMARY OF MONITORING BY OTHER SYSTEMS …………….....................5-1

5.1 GAS MONITORING SYSTEM-2 ………................................................

5.2 GAS CHARACTERIZATION SYSTEM ................................................. $5-1$

5.3 GAS CHROMATOGRAPH RESULTS …....................................................

5.4 AMMONIA MONITORING OF TANK FARM EXHAUST VENTS AND INDIVIDUAL TANKS ............................................................................ 5-4

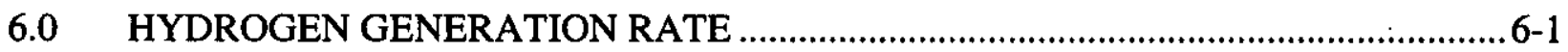

7.0 FLAMMABLE GAS ACTION LEVELS FOR HANFORD WASTE TANKS .............7-1

7.1 DESCRIPTION OF ACTION LEVEL …….........................................................

7.2 ACTION-LEVEL RESPONSE.................................................................. 7-1

7.3 SUMMARY OF GAS RELEASE EVENTS EXCEEDING THE ACTION LEVEL

8.0 MAINTENANCE ISSUES AND ACTIONS PLANS FOR CONTINUED MONITORING

8.1 RELIABILITY OF SHMS INSTRUMENTATION …......................................

8.2 CURRENT SYSTEM ISSUES AND CORRECTIVE ACTIONS .....................8-4

8.2.1 Description of System Issues ........................................................... 8-4

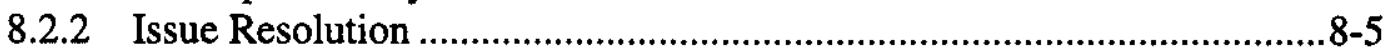


9.0 CONCLUSIONS

10.0 REFERENCES. $10-1$

\section{APPENDICES}

A FLAMMABLE GAS CONCENTRATIONS FOR SHMS TANKS

JULY 1999 THROUGH JUNE 2000.

B VAPOR GRAB SAMPLE RESULTS (BOTH SINGLE- AND DOUBLE-SHELL TANKS)

C FLAMMABLE GAS SCREENING FOR THE LOWER FLAMMABILITY LIMIT. 


\section{LIST OF TABLES}

Table 1-1. Flammable Gas Watch List Tanks.......................................................................1-1

Table 1-2. Non-Watch List Tanks with SHMS...................................................................

Table 2-1. Gas Monitoring Instruments.....................................................................................

Table 3-1. Summary of Gas Release Events for Tank 241-SY-101, Before Mixer Pump Mitigation................................................................................................................3-2

Table 3-2. Summary of Gas Release Events for Tank 241-SY-103. ..............................................3-4

Table 3-3. Summary of Gas Release Events in Tank 241-AW-101.........................................3-5

Table 3-4. Summary of Gas Release Events for Tanks 241-AN-103 and 241-AN-104..............3-6

Table 3-5. Summary of Gas Release Events for Tanks 241-AN-105 and 241-AN-107.............3-7

Table 3-6. Summary of Gas Release Events for Tanks 241-AY-102 and 241-AZ-102 .............3-8

Table 3-7. Amount of Gas Released from GREs in Single-Shell Tanks. (10 sheets) ...............3-10

Table 3-8. Comparison of Monitoring Results with Pump Pit Vapor Samples........................3-21

Table 3-9. Maximum SHMS Readings. (2 sheets)................................................................... 3-22

Table 4-1. SHMS Removal/Standby Status as of June 30, 2000 ...............................................4-2

Table 5-1. Tank 241-SY-101 Gas Monitoring..........................................................................5-2

Table 5-2. GCS Results during GREs (ppm) .........................................................................5-3

Table 8-1. SHMS Data System Reliability. (4 sheets) ..................................................................8-1

Table 8-2. Summary of SHMS Data System Reliability .............................................................8-4 


\section{HNF-SD-WM-TI-797 Rev. 5}

\section{TERMS}

$\mathrm{cfm}$

DACS

DST

FGWL

FTIR

GC

GCS

GMS

GRE

IR

LFL

ppm

SACS

SHMS

SST

TBD

TMACS

VFR cubic feet per minute

Data Acquisition and Control System

double-shell tank

Flammable Gas Watch List

Fourier transform infrared spectrometer

gas chromatograph

Gas Characterization System

Gas Monitoring System

gas release event

infrared

lower flammability limit

parts per million

Surveillance Analysis Computer System

Standard Hydrogen Monitoring System

single-shell tank

to be determined

Tank Monitoring and Control System

vent flow rate 


\subsection{INTRODUCTION}

This report documents measurements of headspace gas concentrations and monitoring results obtained using the sampling systems described in Section 2 of this report. This report has been updated annually since September 1997. This revision includes data collected from July 1999 through June 2000 . The purpose of this report is to present the data, not to interpret how the data represent the safety condition of the tanks.

This report describes the methods used for monitoring or measuring tank headspace gas concentrations, summarizes the measurement results, describes actions to be taken if concentrations reach action levels, and outlines the plans for system improvements and future monitoring.

This information will be useful in developing and validating the models used to predict tank performance, supporting resolution of the Flammable Gas Safety Issue, and assisting with information needed to comply with Hanford Federal Facility Agreement and Consent Order (Tri-Party Agreement) (Ecology et al. 1994) Milestone M-40-00, established to mitigate or resolve tank safety issues for high-priority watch list tanks.

Continuous gas monitors have been installed on the Flammable Gas Watch List (FGWL) tanks as listed in Table 1-1. Several of these monitors were placed in a standby mode or disconnected this year after extensive review of the data collected to date. This activity has been determined to be a "field optimization" and is discussed in Section 4.0. This revision (Rev. 5) continues to address the requirement for continued monitoring plus monitoring results of other tanks of concern.

Table 1-1. Flammable Gas Watch List Tanks.

\begin{tabular}{|l|l|}
\hline \multicolumn{1}{|c|}{ Double-Shell Tanks } & \multicolumn{1}{|c|}{ Single-Shell Tanks } \\
\hline $241-\mathrm{AN}-103,104,105$ & $241-\mathrm{A}-101$ \\
\hline $241-\mathrm{AW}-101$ & $241-\mathrm{AX}-101,103$ \\
\hline $241-\mathrm{SY}-101,103$ & $241-\mathrm{S}-102,111,112$ \\
\hline & $241-\mathrm{SX}-101,102,103,104,105,106,109$ \\
\hline & $241-\mathrm{T}-110$ \\
\hline & $241-\mathrm{U}-103,105,107,108,109$ \\
\hline
\end{tabular}

\subsection{PUBLIC LAW 101-510, SECTION 3137, AND THE FLAMMABLE GAS TANK WATCH LIST}

In November 1990, the National Defense Authorization Act for Fiscal Year 1991, Public Law 101-510, Section 3137, "Safety Measures for Waste Tanks at the Hanford Nuclear Reservation," [the Wyden Amendment] was passed. It required the Secretary of Energy to identify within 90 days high-level nuclear waste tanks that could have a "serious potential for 
release of high-level waste caused by uncontrolled increases in temperature or pressure." The identified tanks contained flammable gas, ferrocyanide, organic chemicals, and high levels of radioactive decay heat.

In January 1991, Westinghouse Hanford Company formally submitted a watch list of tanks subject to the law (Harmon 1991a). In February 1991, Westinghouse Hanford Company submitted a method for selecting flammable gas tanks (Harmon 1991b). The 1991 FGWL identified 23 tanks. In 1992 and 1993, two additional tanks were added bringing the total to 25 . These 6 double-shell tanks (DST) and 19 single-shell tanks (SST) are listed in Table 1-1. All the Watch List tanks have had a Standard Hydrogen Monitoring System (SHMS) installed for gas monitoring. Section 4.0 discusses those monitoring systems that have been disconnected or placed in a standby mode.

\section{$1.2 \quad$ NON-WATCH LIST TANKS}

Other tanks also have operating SHMS. These tanks either show evidence of gas retention or have planned activities that require flammable gas monitoring. Two of the tank farms have SHMS on a common exhaust stack. These tanks and exhaust stacks are listed in Table 1-2. The tank 241-B-111 SHMS was placed into service on May 30, 2000. Several of these SHMS have been disconnected or placed in standby mode. Refer to Section 4.0 for a discussion of SHMS removal.

Table 1-2. Non-Watch List Tanks with SHMS.

\begin{tabular}{|l|l|}
\hline \multicolumn{1}{|c|}{ Double-Shell Tanks } & \multicolumn{1}{c|}{ Single-Shell Tanks } \\
\hline $241-\mathrm{AN}-101, \mathrm{AN}-107$ & $241-\mathrm{B}-111$ \\
\hline $241-\mathrm{AY}-102$ & $241-\mathrm{BY}-103,105,106,109$ \\
\hline $241-\mathrm{AZ}-101,102$ & $241-\mathrm{C}-106$ \\
\hline $241-\mathrm{SY}-102$ & $241-\mathrm{S}-101, \mathrm{~S}-106, \mathrm{~S}-107, \mathrm{~S}-109$ \\
\hline AN FARM (Exhaust Stack) & $241-\mathrm{U}-102$ \\
\hline AW FARM (Exhaust Stack) & \\
\hline
\end{tabular}




\subsection{DESCRIPTION OF THE FLAMMABLE GAS MONITORING SYSTEMS}

The tanks are monitored for hydrogen and other flammable gases to ensure that the tank headspace is safe and to increase the understanding of the mechanisms for gas release and dispersion. A number of different systems are in use. Depending on the information desired from a tank, different monitoring instruments are combined into a tank-specific system. These instruments, along with their measurement accuracy and ranges, are listed in Table 2-1. The following sections describe how the instruments are applied in different monitoring systems.

Table 2-1. Gas Monitoring Instruments.

\begin{tabular}{|c|c|c|c|}
\hline Instrument & Gases Monitored & Range & Accuracy \\
\hline $\begin{array}{l}\text { Whittaker }{ }^{\mathrm{TM}} \text { electro- } \\
\text { chemical cell and } \\
\text { transmitter ( } 2 \text { units) }\end{array}$ & Hydrogen specific & $\begin{array}{l}0 \text { to } 1 \% \text { and } 0 \text { to } 10 \% \mathrm{H}_{2} \text { by } \\
\text { volume }\end{array}$ & $\begin{array}{l} \pm 0.2 \% \text { by volume } \\
\text { absolute (resolution of } \\
50 \text { ppm) }\end{array}$ \\
\hline $\begin{array}{l}\text { Gas chromatograph } \\
\text { reduction gas analyzer } \\
\text { (GC-RGA) }\end{array}$ & Hydrogen specific & $\begin{array}{l}\text { Low range } \\
0 \text { to } 500 \mathrm{ppm} \mathrm{H}_{2} \\
\text { High range } \\
500-30,000 \mathrm{ppm} \mathrm{H}_{2}\end{array}$ & $\begin{array}{l}\text { Low range } \\
\pm 4 \text { ppm }<100 \text { ppm and } \\
\pm 10 \% \text { of reading } \\
>100 \text { ppm } \\
\text { High range } \\
\pm 10 \% \text { of reading }\end{array}$ \\
\hline $\begin{array}{l}\text { Gas chromatograph } \\
\text { thermal conductivity } \\
\text { detector (GC-TCD) }\end{array}$ & $\begin{array}{l}\text { Hydrogen }\left(\mathrm{H}_{2}\right) \\
\text { Nitrous oxide }\left(\mathrm{N}_{2} \mathrm{O}\right) \\
\text { Methane }\left(\mathrm{CH}_{4}\right)\end{array}$ & $\begin{array}{l}\mathrm{H}_{2}: 3 \text { to } 3,000 \mathrm{ppm} \\
\mathrm{N}_{2} \mathrm{O}: 10 \text { to } 20,000 \mathrm{ppm} \\
\mathrm{CH}_{4}: 10 \text { to } 4,000 \mathrm{ppm}\end{array}$ & $\begin{array}{l}\mathrm{H}_{2}, \mathrm{~N}_{2} \mathrm{O}, \text { and } \mathrm{CH}_{4} \\
\pm 3 \mathrm{ppm}<30 \mathrm{ppm} \text { and } \\
\pm 10 \% \text { of reading } \\
>30 \mathrm{ppm}\end{array}$ \\
\hline $\begin{array}{l}\text { Fourier transform infrared } \\
\text { spectrometer (FIIR) }\end{array}$ & $\begin{array}{l}\text { Ammonia }\left(\mathrm{NH}_{3}\right) \\
\text { Nitrous oxide }\left(\mathrm{N}_{2} \mathrm{O}\right) \\
\text { IR spectra for other } \\
\text { species }\end{array}$ & $\begin{array}{l}\mathrm{NH}_{3}: 10 \text { to } 30,000 \mathrm{ppm} \\
\mathrm{N}_{2} \mathrm{O}: 10 \text { to } 30,000 \mathrm{ppm} \\
\text { Other species TBD }\end{array}$ & $\begin{array}{l}\mathrm{N}_{2} \mathrm{O} \& \mathrm{NH}_{3} \\
\pm 5 \mathrm{ppm}<100 \mathrm{ppm} \\
\pm 10 \% \text { of reading } \\
>100 \mathrm{ppm}\end{array}$ \\
\hline $\begin{array}{l}\text { Infrared photo acoustic } \\
\text { multi-gas monitor }\end{array}$ & $\begin{array}{l}\text { Ammonia }\left(\mathrm{NH}_{3}\right) \\
\text { Selected filters for other } \\
\text { species }\end{array}$ & $\begin{array}{l}\mathrm{NH}_{3}: 10 \text { to } 10,000 \mathrm{ppm} \\
\text { Other species TBD }\end{array}$ & $\begin{array}{l}\mathrm{NH}_{3} \\
\pm 10 \mathrm{ppm}<100 \mathrm{ppm} \\
\pm 10 \% \text { of reading } \\
>100 \mathrm{ppm}\end{array}$ \\
\hline $\begin{array}{l}\text { Grab samples - mass } \\
\text { spectrometer }\end{array}$ & $\begin{array}{l}\text { Hydrogen }\left(\mathrm{H}_{2}\right) \\
\text { Nitrous oxide }\left(\mathrm{N}_{2} \mathrm{O}\right) \\
\text { Methane }\left(\mathrm{CH}_{4}\right) \\
\text { Argon }(\mathrm{Ar}) \\
\text { Nitrogen }\left(\mathrm{N}_{2}\right) \\
\text { Oxygen }\left(\mathrm{O}_{2}\right)\end{array}$ & 0 to $100 \%$ by volume & $\pm 10 \mathrm{ppm}$ \\
\hline
\end{tabular}

Whittaker ${ }^{T M}$ is a trademark of Whittaker Safety Systems, Simi Valley, California. 


\subsection{STANDARD HYDROGEN MONITORING SYSTEMS}

The basic SHMS monitors hydrogen continuously. Gas is vacuum pumped from the tank into a temperature-controlled cabinet that contains the monitoring instrument. For FGWL DSTs, the sample is obtained from the tank ventilation exhaust duct; for SSTs and the non-Watch List DSTs, a sample is obtained from a probe inserted deep into the tank headspace. The monitoring instrument is a hydrogen-specific Whittaker ${ }^{T M}$ electrochemical cell. The cell generates an electrical signal proportional to the volume percent hydrogen concentration. The signal is processed by an analog to digital transmitter. The 4 to $20 \mathrm{~mA}$ output from the transmitter is sent to a digital data readout and to the data recorder. The recording channel of the data recorder is programmed to activate an alarm relay if a preset hydrogen concentration (currently 6,250 ppm) is reached. The alarm relay opens a normally closed contact that serves as the input to a programmable logic controller that controls the annunciation of a high-hydrogen alarm and initiates an automatic vapor grab sample. Data for most of the SHMS are recorded by a connection to the Tank Monitoring and Control System (TMACS); other SHMS units have an on-board chart recorder or an on-board data logger.

Each SHMS also has a grab sample station that allows two $75 \mathrm{cc}$ vapor samples to be taken simultaneously from the gas stream. These "grab samples" are then isolated and transported to a laboratory for analysis. Hydrogen and other gas concentrations can be measured using these samples.

These systems are calibrated quarterly. A mixture of $100 \mathrm{ppm}$ hydrogen in air is used to adjust the low end of the hydrogen sensor and a mixture of 5.0 percent hydrogen mixed with nitrogen is used to balance the high end of the sensor. A mid-range standard gas of 1,000 ppm hydrogen is used as an on-line calibration check during system operation (Schneider 1996).

The first basic SHMS unit was developed for use in continuously monitoring hydrogen concentrations in tank 241-SY-101. Three of the basic units currently are installed and operating on this tank. One system monitors the vent header concentration; the other two monitor locations within the headspace. Based on the success of these instruments, the system was upgraded for other tanks by adding the capability to automatically obtain a grab sample if a highhydrogen reading is detected. The WhittakerTM cells were configured so that one covers a high range ( 0 to 10 percent by volume) and another covers a low range ( 0 to 1 percent by volume). This modified version is called the SHMS-B.

The SHMS-B is the most widely used SHMS instrument. It is installed on all FGWL tanks other than 241-SY-101 and 24l-AN-104. Data are recorded by connection to the TMACS and by the on-board chart recorder. As specific needs have arisen, the SHMS-B has been modified to provide additional capabilities. This has resulted in several variations, including models $\mathrm{C}, \mathrm{D}, \mathrm{E}$, and E+. Table 3-9 lists the tanks and the type of SHMS currently installed in each.

The SHMS-C is a SHMS-B modified to accommodate a data column gas chromatograph (GC) with thermal conductivity detectors. Data for the Whittaker ${ }^{\mathrm{TM}}$ cells are recorded by connection to the TMACS and/or by the on-board chart recorder. The data from the $\mathrm{GC}$ are recorded by a resident computer and stored on a floppy disk for off-line analysis. The SHMS-C is designed to 
accurately record baseline hydrogen concentrations that are well below the range of the Whittaker ${ }^{\mathrm{TM}}$ cells.

The SHMS-D is a SHMS-B modified to accommodate an infrared (IR) photo-acoustic multi-gas monitor for measuring ammonia. Data from the Whittaker ${ }^{\mathrm{MM}}$ cells are recorded by connection to TMACS and/or by the on-board chart recorder. The data from the IR photo-acoustic multi-gas monitor are recorded by a resident computer and stored on a floppy disk for off-line analysis. The SHMS-D was developed for use in monitoring ammonia concentrations in the ventilation exhaust of DSTs.

The SHMS-E is an updated version of the SHMS-B and accommodates a dual-column GC with a thermal conductivity detector and an IR photo-acoustic multi-gas monitor. However, the detector and monitor are not installed. Data are recorded by an on-board digital data logger with data stored on a floppy disk. The upgrade in the design from the SHMS-B is in the data recording (the strip-chart is eliminated) and the programmable logic controller. The SHMS-E is intended for use in the same applications as a SHMS-B. The SHMS-E has the advantage of easily being upgraded to an E+.

The SHMS-E+ is a SHMS-E with a GC and IR monitor installed. The GC monitors hydrogen, nitrous oxide, and methane, and the IR monitor detects ammonia. An on-board digital data logger records data on a floppy disk or by connection to a host computer through the Hanford Local Area Network. The SHMS-E+ is intended for applications similar to those with the Gas Characterization System (GCS) described in Section 2.2. The SHMS-E+ provides nearly the same measurement capability as a GCS but at a significantly lower cost.

\subsection{OTHER MONITORING SYSTEMS}

The Gas Monitoring System-1 (GMS-1) monitors hydrogen and tank headspace pressure in tank 241-SY-101. The environmentally controlled enclosure contains one Whittaker ${ }^{\mathrm{TM}}$ electrochemical cell and a grab sample station. It also has a pressure transmitter. It initially had a mass spectrometer for multi-specie analysis that has been removed. Data from GMS-1 are recorded by the 241-SY-101 Mixer Pump Data Acquisition and Control System (DACS).

The Gas Monitoring System-2 (GMS-2) is an environmentally controlled enclosure containing a Fourier transform infrared spectrometer (FTIR), two hydrogen-specific GCs and one IR photoacoustic monitor. GMS-2 monitors the headspace of tank 241-SY-101. The FTIR measures ammonia and nitrous oxide. One $\mathrm{GC}$ has a single column and monitors low concentrations of hydrogen; the other GC has a dual-column arrangement and monitors both low and high concentrations of hydrogen. The IR monitor samples the ventilation exhaust stack of the SY farm (combined exhaust from tanks 241-SY-101, -102, and -103) for ammonia. The data are recorded by the 241-SY-101 DACS. GMS-1 and GMS-2 provide the detailed concentration history necessary to support the mixer pump operation. The data from these systems have significantly contributed to the understanding of this tank.

The GCS is an environmentally controlled enclosure with an FTIR, two dual-column thermal conductivity GCs, and a grab sample station. The GCS is an upgraded version of the GMS-2. The FTIR monitors ammonia, one GC monitors hydrogen, and the other GC measures nitrous 
HNF-SD-WM-TI-797 Rev. 5

oxide and methane. The data are recorded by the resident computer system and can be remotely accessed over the Hanford Local Area Network. The GCS is used to provide the detailed history of gas concentration over a wide range to support the decision of whether additional means are needed to mitigate the safety issue of a tank. These systems are currently installed on tanks 241-AN-105 and 241-AW-101. 


\subsection{GAS RELEASE EVENTS}

In this document, a gas release event (GRE) is defined as an abrupt increase in tank headspace hydrogen concentration from the steady-state level, followed by a decrease back to the steady-state concentration. The hydrogen increase from steady-state to a peak concentration can take minutes or hours in a DST and days in an SST. The gas release may be accompanied by a drop in waste level, indicating the waste volume has decreased because of the release of gas. However, the tanks do not consistently show a level drop with each release. If a release occurs in one small area of the tank, the level may drop in that small area but not affect the waste near the level measurement device. The level drop also may be too small to be detected with the level instrument installed in the tank. Also, some gas may be trapped in the waste crust, causing a temporary increase in waste level. The tables in this section illustrate the wide range of variability in the change in levels.

Gas releases have several causes. Gas trapped in the waste can build up until the waste becomes buoyant. As the waste floats up, gas is released and, after the waste returns to less than neutral buoyancy, the waste resettles. Such waste movement can be monitored with thermocouples installed at different elevations in the waste. Temperatures change by several degrees within hours when warm waste rises and is replaced by the cooler supernatant liquid. This type of gas release is called "buoyant displacement" and occurs in several DSTs (Stcwart et al. 1996a). Buoyant displacements (historically called "rollovers") are not believed to occur in SSTs (Stewart et al. 1996b).

Gas releases in the SSTs have been observed to usually be associated with changes in barometric pressure. These releases have been very small compared to those seen in the DSTs. Low barometric pressure is believed to decrease the pressure on the trapped gas and allow the gas to expand and percolate to the surface of the waste.

Small gas releases also have occurred in a few cases when the waste was disturbed during work activities. Recent intrusive activities to ameliorate the crust rise in tank 241-SY-101 showed a release every time the waste was disturbed. A hydrogen concentration "spike" was evident in both tanks 241-SY-101 and 241-SY-102 during a transfer from the former to the latter in December 1999 (subsequent transfers did not result in such dramatic hydrogen responses - see Appendix A, Figure 46). Currently, hydrogen gas concentration levels are rising in correlation with saltwell pumping activity in several SSTs, particularly in the U farm. Similar increases in hydrogen gas concentrations were observed coincidental with mixer pump and airlift circulator tests in tank 241-AZ-101. Since these releases are not generated spontaneously, they are not evaluated in the same manner as GREs (Section 3.4).

\subsection{1-SY-101 GAS RELEASE EVENTS}

Table 3-1 lists the GREs that have been detected in tank 24l-SY-101 between 1990 and July 1993, before mitigation with a mixer pump. During 9 of the 11 gas releases before July 1993, hydrogen concentrations in the headspace were above 25 percent of the lower flammability limit (LFL) for hydrogen. The LFL for hydrogen in air is about 4 percent or $40,000 \mathrm{ppm}$. Three releases increased the headspace hydrogen concentration beyond the LFL. Level drops ranging 
from 12.7 to $33.5 \mathrm{~cm}$ accompanied the gas releases in this tank. The time between gas releases averaged 116 days \pm 25 . The gas releases were somewhat predictable based on the number of days between releases.

The peak hydrogen concentrations listed for GREs that occurred during 1990 were measured with a thermal conductivity analyzer, which is no longer used. The February 1991 GRE was very slow and barely registered above background levels for hydrogen on the monitoring instruments. The peak concentration listed was measured with an on-line mass spectrometer, which is no longer used. GMS-1 was installed in April 1991, and its Whittaker ${ }^{\mathrm{TM}}$ cell measured the peak concentrations listed for the May, August, and December 1991 GREs. Two SHMS and GMS-2 were installed during 1992. Further details on tank 241-SY-101 gas instrumentation before 1992 are available in Babad et al. (1992).

Table 3-1. Summary of Gas Release Events for Tank 241-SY-101, Before Mixer Pump Mitigation.

\begin{tabular}{|c|c|c|c|}
\hline $\begin{array}{c}\text { Date } \\
04 / 19 / 90\end{array}$ & $\begin{array}{c}\text { Concentration }^{1} \\
\text { (ppm) }\end{array}$ & $\begin{array}{c}\text { Level Drop }^{\mathbf{2 3}} \\
\text { (cm) }\end{array}$ & $\begin{array}{c}\text { Days Since } \\
\text { Previous GRE }\end{array}$ \\
\hline $08 / 05 / 90$ & 35,000 & 23.6 & \\
\hline $10 / 24 / 90$ & 12,000 & 13.2 & 108 \\
\hline $02 / 16 / 91$ & 47,000 & 25.4 & 80 \\
\hline $05 / 16 / 91$ & 400 & 12.7 & 115 \\
\hline $08 / 27 / 91$ & 28,000 & 18.3 & 89 \\
\hline $12 / 04 / 91$ & 3800 & 15.2 & 103 \\
\hline $04 / 20 / 92$ & 53,000 & 33.0 & 99 \\
\hline $09 / 03 / 92$ & 14,800 & 18.3 & 138 \\
\hline $02 / 02 / 93$ & 51,200 & 33.5 & 136 \\
\hline $06 / 26 / 93$ & 27,400 & 21.6 & 144 \\
\hline Average number of days between GREs $=116$ & 24.8 & \\
\hline Standard deviation (days) $=25$ & & \\
\hline
\end{tabular}

Notes:

'SHMS data

${ }^{2} \mathrm{SACS}$ (Surveillance Analysis Computer System) data

${ }^{3}$ Level drop is measured from the pre-GRE level to the minimum level following the GRE. The waste level may not stabilize until a few days after the GRE. 
Vapor data specific to tank 24l-SY-101 are reported quarterly. These quarterly reports provide greater detail regarding changes in tank waste level, temperature, gas releases, and mixer pump parameters. They discuss any core or grab sampling activities for the tank and summarize waste behavior. The three reports that coincide with the time frame for this report are Conner and Koreski (1999), Conner and Koreski (2000a), and Conner and Koreski (2000b).

\subsection{GAS RELEASE EVENTS FROM OTHER DOUBLE-SHELL TANKS}

Tables 3-2 through 3-6 list the gas releases detected with gas monitoring in the other DSTs. Only two other DSTs, tanks 241-AW-101 and 241-AN-105, have had gas releases that have exceeded 25 percent of the LFL. None of these releases exceeded the LFL. Level drops in these tanks following gas releases are generally less than $2.5 \mathrm{~cm}$. These measurements show that the GREs in these tanks are much smaller than those seen in tank 241-SY-101 before mitigation. The average number of days between gas releases is less than 100 in tanks $241-\mathrm{AW}-101$ and 241-SY-103. However, the standard deviations of these averages are almost as large as the averages. Using the time period to predict future gas releases for these tanks does not appear feasible from existing data. A gas release in a tank on one day does not guarantee another gas release will not happen the next day. During October 1995, three separate hydrogen increases occurred in tank 241-AN-104 during a 9-day period. However, the hydrogen concentration in the headspace remained low. The only tank with consistent hydrogen increases historically above 25 percent of the LFL is tank 241-AN-105. Tank 241-AN-105 had two fairly significant hydrogen releases in July and August 1999. These were the highest peak concentrations of any tanks monitored and, at 7,100 and 7,620 ppmv, respectively, the concentration appeared to exceed 25 percent of the LFL. However, using measurements of hydrogen, methane, and ammonia (available by gas chromatography), the actual flammable gas releases were determined to be 18.0 and 19.2 percent of the LFL. Based on the size of the releases seen in these tanks, events in these tanks appear to be localized and not involve the entire tank contents. The AN farm stack monitor detected several gas releases, particularly the July and August 1999 releases in tank 241-AN-105. 
Table 3-2. Summary of Gas Release Events for Tank 241-SY-103.

\begin{tabular}{|c|c|c|c|}
\hline Date & $\begin{array}{c}\text { Maximum } \\
\mathrm{H}_{2} \text { Concentration' } \\
(\mathbf{p p m})\end{array}$ & $\begin{array}{c}\text { Level Drop }{ }^{2,3} \\
(\mathrm{~cm})\end{array}$ & $\begin{array}{c}\text { Days Since } \\
\text { Previous GRE }\end{array}$ \\
\hline $01 / 22 / 95$ & 1,090 & 1.5 & \\
\hline $03 / 01 / 95$ & 2,230 & 3.0 & 38 \\
\hline $05 / 02 / 95$ & 2,940 & 2.2 & 62 \\
\hline $08 / 23 / 95$ & 1,260 & 0.9 & 113 \\
\hline $09 / 06 / 95$ & 1,890 & 2.5 & 14 \\
\hline $12 / 03 / 95$ & 740 & 0.7 & 88 \\
\hline $06 / 06 / 96$ & 1,090 & 1.0 & 186 \\
\hline $07 / 14 / 96$ & 2,170 & 1.8 & 38 \\
\hline $12 / 20 / 96$ & 5,110 & 6.1 & 159 \\
\hline $11 / 27 / 97$ & 2,660 & 5.9 & 130 \\
\hline $12 / 07 / 97$ & 2,060 & 4.7 & 140 \\
\hline $08 / 15 / 98$ & 1,660 & 2.3 & 251 \\
\hline $10 / 23 / 98$ & 1,140 & 1.9 & 69 \\
\hline $12 / 25 / 98$ & 3,160 & 4.8 & 63 \\
\hline $01 / 10 / 99$ & 690 & 0.36 & 16 \\
\hline $03 / 09 / 99$ & 570 & 0.99 & 58 \\
\hline $05 / 30 / 99$ & 950 & 4.8 & 82 \\
\hline $10 / 26 / 99$ & 1,020 & 1.40 & 149 \\
\hline $11 / 26 / 99$ & 608 & 0.33 & 31 \\
\hline $12 / 03 / 99$ & 570 & 0.51 & 7 \\
\hline $01 / 16 / 00$ & 1,100 & 0.91 & 44 \\
\hline $02 / 12 / 00$ & 390 & 1.12 & 27 \\
\hline $03 / 13 / 00$ & 1,240 & 1.14 & 30 \\
\hline \multicolumn{4}{|c|}{ Average number of days between GREs $=82$} \\
\hline \multicolumn{4}{|c|}{ Standard deviation $=64$} \\
\hline
\end{tabular}

Notes:

'SHMS data

${ }^{2}$ SACS (Surveillance Analysis Computer System) data

${ }^{3}$ Level drop is measured from the pre-GRE level to the minimum level following the GRE. The waste level may not stabilize until a few days after the GRE. 
HNF-SD-WM-TI-797 Rev. 5

Table 3-3. Summary of Gas Release Events in Tank 241-AW-101.

\begin{tabular}{|c|c|c|c|}
\hline Date & $\begin{array}{c}\text { Maximum } \\
\mathrm{H}_{2} \text { Concentration } \\
\text { (ppm) }\end{array}$ & $\begin{array}{c}\text { Level Drop } \\
\text { (cm) }\end{array}$ & $\begin{array}{c}\text { Days Since } \\
\text { Previous GRE }\end{array}$ \\
\hline $10 / 01 / 94$ & 5,500 & 1.9 & \\
\hline $10 / 04 / 94$ & 8,800 & Not detected & 3 \\
\hline $10 / 21 / 94$ & 2,980 & 0 & 17 \\
\hline $11 / 27 / 94$ & 5,000 & 0 & 37 \\
\hline $02 / 22 / 95$ & 5,800 & 0 & 87 \\
\hline $05 / 08 / 95$ & 1,800 & 0 & 75 \\
\hline $05 / 17 / 95$ & 1,000 & 0.9 & 9 \\
\hline $07 / 08 / 95$ & 2,000 & 0 & 52 \\
\hline $07 / 12 / 95$ & 900 & 0 & 4 \\
\hline $08 / 02 / 95$ & 3,300 & 0 & 21 \\
\hline $09 / 15 / 95$ & 1,900 & +0.2 & 44 \\
\hline $09 / 22 / 95$ & 4,660 & +2.0 & 7 \\
\hline $10 / 16 / 95$ & 1,750 & 0.3 & 24 \\
\hline $12 / 12 / 95$ & 2,110 & 0.3 & 57 \\
\hline $12 / 29 / 95$ & 6,000 & +0.7 & 17 \\
\hline $01 / 13 / 96$ & 1,170 & Not detected & 15 \\
\hline $01 / 25 / 96$ & 1,830 & Not detected & 12 \\
\hline $02 / 05 / 96$ & 3,200 & +0.5 & 11 \\
\hline $02 / 14 / 96$ & 940 & Not detected & 9 \\
\hline $05 / 14 / 96$ & 1,455 & 0.2 & 90 \\
\hline $06 / 05 / 96$ & 2,500 & 0.2 & 22 \\
\hline $04 / 21 / 98$ & 398 & 0.6 & 685 \\
\hline $06 / 24 / 98$ & 450 & 0.2 & 64 \\
\hline $07 / 04 / 98$ & 480 & 0.5 & 10 \\
\hline $01 / 16 / 00$ & 210 & 0.6 & 561 \\
\hline $04 / 22 / 00$ & 2,092 & 0.7 & 97 \\
\hline \multicolumn{4}{|c|}{ Average number of days between GREs $=81$} \\
\hline \multicolumn{4}{|c|}{ Standard deviation $=167$} \\
\hline
\end{tabular}

Notes:

${ }^{1}$ SHMS data

${ }^{2}$ SACS (Surveillance Analysis Computer System) data

${ }^{3}$ Level drop is measured from the pre-GRE level to the minimum level following the GRE. The waste level may not stabilize until a few days after the GRE. 
Table 3-4. Summary of Gas Release Events for Tanks 241-AN-103 and 241-AN-104.

\begin{tabular}{|c|c|c|c|c|}
\hline Tank & Date & $\begin{array}{c}\text { Maximum } \\
\mathrm{H}_{2} \text { Concentration } \\
(\mathbf{p p m})\end{array}$ & $\begin{array}{l}\text { Level Drop } \\
\text { (cm) }\end{array}$ & $\begin{array}{c}\text { Days Since } \\
\text { Previous GRE }\end{array}$ \\
\hline \multirow[t]{5}{*}{$241-\mathrm{AN}-103$} & $08 / 22 / 95$ & 3,000 & 0.6 & \\
\hline & $04 / 11 / 98$ & 960 & 0 & 963 \\
\hline & $02 / 01 / 99$ & 900 & 1.0 & 296 \\
\hline & 09/04/99 & 1,560 & 0.6 & 215 \\
\hline & $12 / 30 / 99$ & 530 & None & 117 \\
\hline \multirow[t]{18}{*}{ 241-AN-104 } & $11 / 06 / 94$ & 3,000 & 5.3 & \\
\hline & $02 / 16 / 95$ & 2,088 & 0.2 & 102 \\
\hline & $08 / 03 / 95$ & 480 & 0 & 168 \\
\hline & $10 / 02 / 95$ & 3,200 & +0.8 & 60 \\
\hline & $10 / 05 / 95$ & 1,000 & 0 & 3 \\
\hline & $10 / 08 / 95$ & 5,000 & 0.7 & 3 \\
\hline & $05 / 03 / 96$ & 6,109 & 1.4 & 208 \\
\hline & $05 / 01 / 97$ & 2,183 & 0.4 & 363 \\
\hline & $08 / 25 / 98$ & 310 & None & 481 \\
\hline & $09 / 26 / 98$ & 310 & 0.3 & 32 \\
\hline & $12 / 02 / 98$ & 550 & 0.4 & 67 \\
\hline & $04 / 26 / 99$ & 135 & None & 145 \\
\hline & $06 / 01 / 99$ & 151 & None & 36 \\
\hline & $07 / 02 / 99$ & 249 & 0.48 & 31 \\
\hline & $08 / 01 / 99$ & 181 & 0.10 & 30 \\
\hline & 09/04/99 & 155 & None & 34 \\
\hline & $05 / 03 / 00$ & 267 & None & 242 \\
\hline & $06 / 02 / 00$ & 264 & 0.18 & 30 \\
\hline \multirow[t]{2}{*}{$241-\mathrm{AN}-103$} & \multicolumn{4}{|c|}{ Average number of days between GREs $=398$} \\
\hline & \multicolumn{4}{|c|}{ Standard deviation $=384$} \\
\hline \multirow[t]{2}{*}{$241-\mathrm{AN}-104$} & \multicolumn{4}{|c|}{ Average number of days between GREs $=120$} \\
\hline & \multicolumn{4}{|c|}{ Standard deviation $=136$} \\
\hline
\end{tabular}

Notes:

${ }^{1}$ SHMS data

${ }^{2}$ SACS (Surveillance Analysis Computer System) data

${ }^{3}$ Level drop is measured from the pre-GRE level to the minimum level following the GRE. The waste level may not stabilize until a few days after the GRE. 
HNF-SD-WM-TI-797 Rev. 5

Table 3-5. Summary of Gas Release Events for Tanks 241-AN-105 and 241-AN-107.

\begin{tabular}{|c|c|c|c|c|}
\hline Tank & Date & $\begin{array}{c}\text { Maximum } \\
\mathbf{H}_{2} \text { Concentration } \\
\text { (ppm) }\end{array}$ & $\begin{array}{c}\text { Level Drop } \\
\text { (cm) }\end{array}$ & $\begin{array}{c}\text { Days Since } \\
\text { Previous GRE }\end{array}$ \\
\hline \multirow[t]{13}{*}{ 241-AN-105 } & $08 / 21 / 95$ & 17,000 & 3.8 & \\
\hline & $05 / 30 / 96$ & 14,500 & 2.5 & 283 \\
\hline & $04 / 05 / 97$ & 6,980 & 0.8 & 310 \\
\hline & $09 / 25 / 97$ & 950 & None & 173 \\
\hline & $11 / 22 / 97$ & 1,030 & None & 58 \\
\hline & $12 / 31 / 97$ & 3,940 & None & 39 \\
\hline & $09 / 01 / 98$ & 2,280 & 0.4 & 244 \\
\hline & $03 / 07 / 99$ & 760 & None & 187 \\
\hline & $05 / 02 / 99$ & 182 & None & 56 \\
\hline & $07 / 28 / 99$ & 7,100 & 1.45 & 87 \\
\hline & $08 / 02 / 99$ & 7,620 & 1.37 & 5 \\
\hline & $10 / 27 / 99$ & 180 & None & 86 \\
\hline & $01 / 01 / 00$ & 186 & None & 66 \\
\hline 241-AN-107 & $04 / 30 / 00$ & 290 & None & \\
\hline 241-AN-105 & \multicolumn{4}{|c|}{ Average number of days between GREs $=133$} \\
\hline & \multicolumn{4}{|c|}{ Standard Deviation $=103$} \\
\hline
\end{tabular}

Notes:

'SHMS data

${ }^{2}$ SACS (Surveillance Analysis Computer System) data

${ }^{3}$ Level drop is measured from the pre-GRE level to the minimum level following the GRE. The waste level may not stabilize until a few days after the GRE. 
Table 3-6. Summary of Gas Release Events for Tanks 241-AY-102 and 241-AZ-102.

\begin{tabular}{|c|c|c|c|c|}
\hline Tank & $\begin{array}{r}\text { Maximum } \\
\text { Date }\end{array}$ & $\begin{array}{r}\mathbf{H}_{\mathbf{2}} \begin{array}{c}\text { Concentration } \\
\text { (ppm) }\end{array} \\
\text { Level Drop }\end{array}$ & $\begin{array}{c}\text { Days Since } \\
\text { (cm) }\end{array}$ & Previous GRE \\
\hline $241-\mathrm{AY}-102$ & $01 / 05 / 00$ & 260 & 0.51 & \\
\hline $241-\mathrm{AZ}-102$ & $09 / 27 / 99$ & 450 & None & \\
\hline & $01 / 16 / 00$ & 700 & None & 111 \\
\hline & $02 / 09 / 00$ & 440 & None & 24 \\
\hline $241-\mathrm{AZ}-102$ & \multicolumn{3}{|l|}{ Average number of days between GREs $=68$} \\
\hline
\end{tabular}

Notes:

${ }^{1}$ SHMS data

${ }^{2}$ SACS (Surveillance Analysis Computer System) data

${ }^{3}$ Level drop is measured from the pre-GRE level to the minimum level following the GRE. The waste level may not stabilize until a few days after the GRE.

\subsection{GAS RELEASE EVENTS FROM SINGLE-SHELL TANKS}

SSTs appear to have small, localized GREs that are most likely caused by changes in barometric pressure. No surface level drops have been associated with these events and the hydrogen concentrations following the events all have been below 1,500 ppm.

The hydrogen signature of a gas release shows a fairly sharp rise from a steady-state concentration followed by a steady decrease back to the steady-state concentration. A two-step process calculates the volume of gas released.

First, the vent flow rate (VFR) during the GRE is determined by

$$
\mathrm{VFR}=(\mathrm{Vd}) /(\mathrm{tp}-\mathrm{ts}) \times[\ln (\mathrm{Hp})-\ln (\mathrm{Hs})]
$$

where

$$
\begin{aligned}
& H_{p}=\text { peak hydrogen concentration } \\
& H_{s}=\text { steady-state concentration (post release) } \\
& t_{p}=\text { time of peak concentration } \\
& t_{s}=\text { time when release returns to steady-state concentration } \\
& V_{d}=\text { headspace volume of the tank. }
\end{aligned}
$$

Then, the actual release is calculated by integrating the area beneath the curve that describes the release event (in terms of time versus concentration), from event initiation through return to steady-state. The units for this integrated value are adjusted with the appropriate conversion 
factors to allow multiplication by the derived vent flow rate. The result is the total volume of gas released in the GRE.

The dates of gas releases as well as their duration, peak concentrations, and amount of gas released are listed in Table 3-7. Only 10 SSTs had gas releases this measurement period. Each of these 10 tanks has had a previous gas release. None of the 19 remaining SST monitors detected GREs.

The results of hydrogen release volume calculations, seen in Table 3-7, indicate what can be expected from these tanks. The estimation of hydrogen gas release volumes is sensitive to the selected starting point of the release, the SHMS baseline offset and calibration, the magnitude of the SHMS concentration peak, and any drift that may occur in the SHMS data over the period of several months. This results in uncertainties of 2 to 3 times the calculated value in Table 3-7. Nevertheless, these releases are relatively small and are spread over long periods of time. Longer term shifts in hydrogen concentration, as were found with the saltwell pumping of tank 241-U-105, are not considered the same as a GRE, although a sharp increase in hydrogen concentration occurred followed by a sustained higher steady-state concentration. Steady-stateto-peak differences of less than or equal to $100 \mathrm{ppm}$ were not recorded on Table 3-7. 


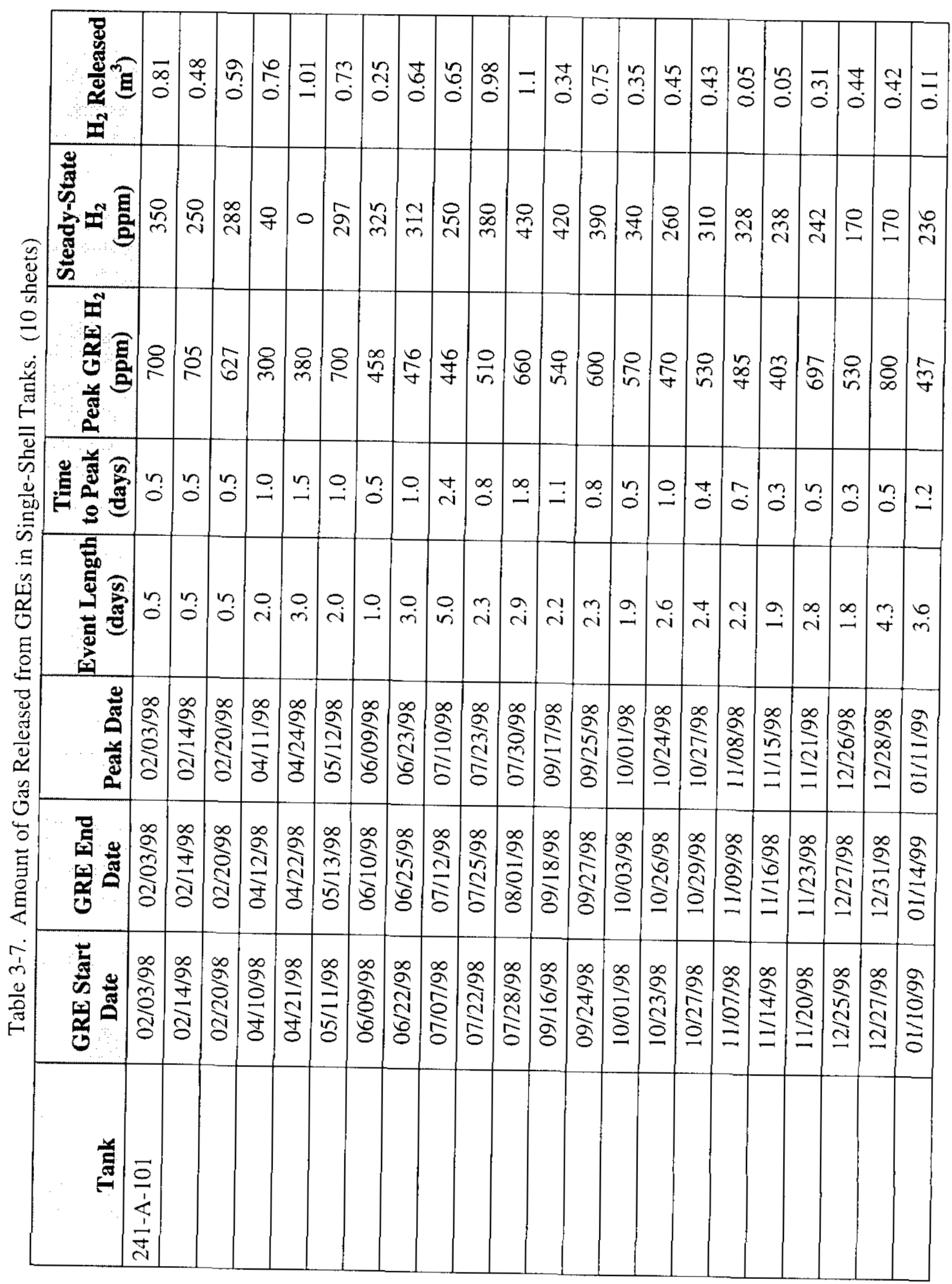




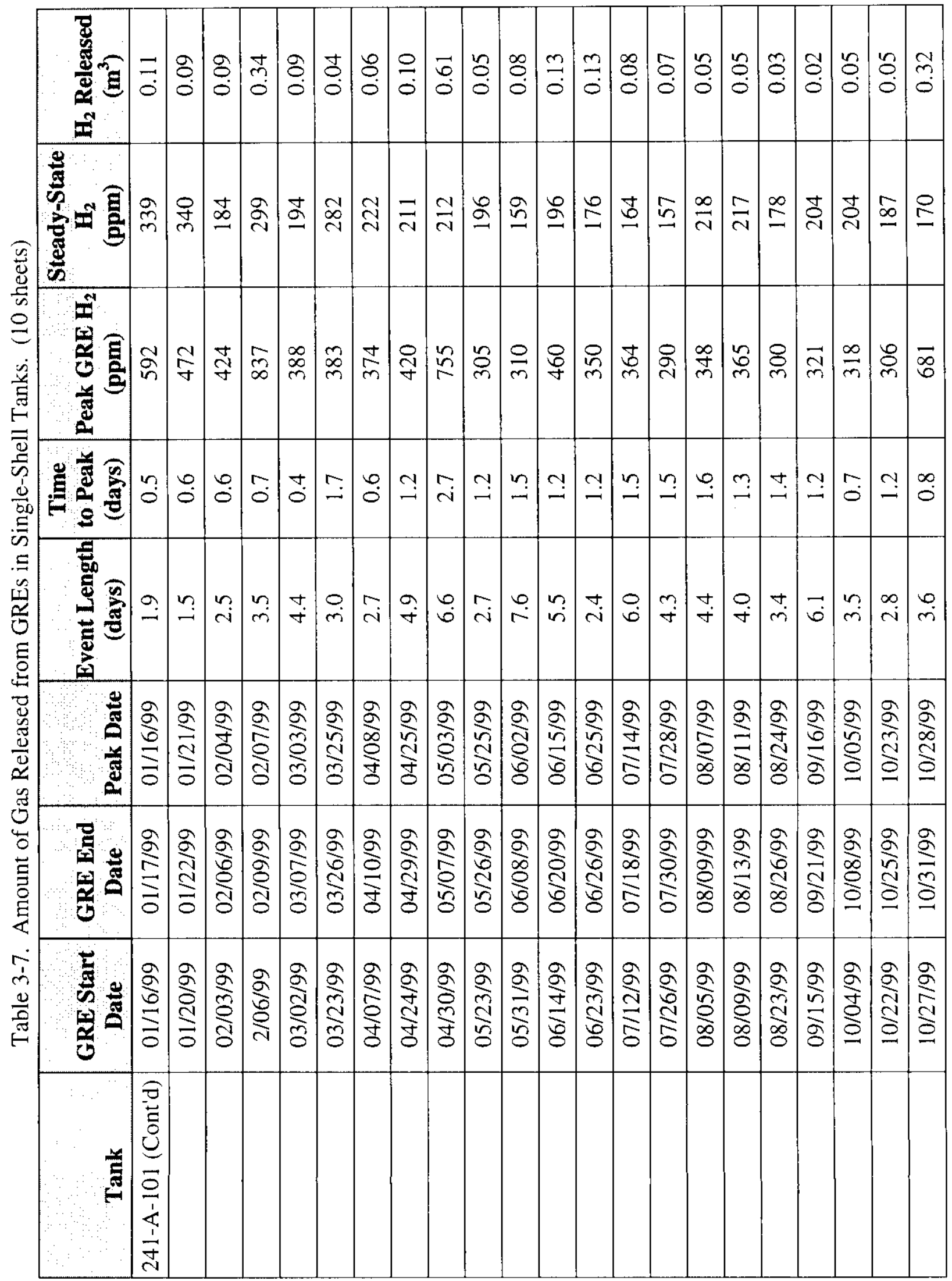




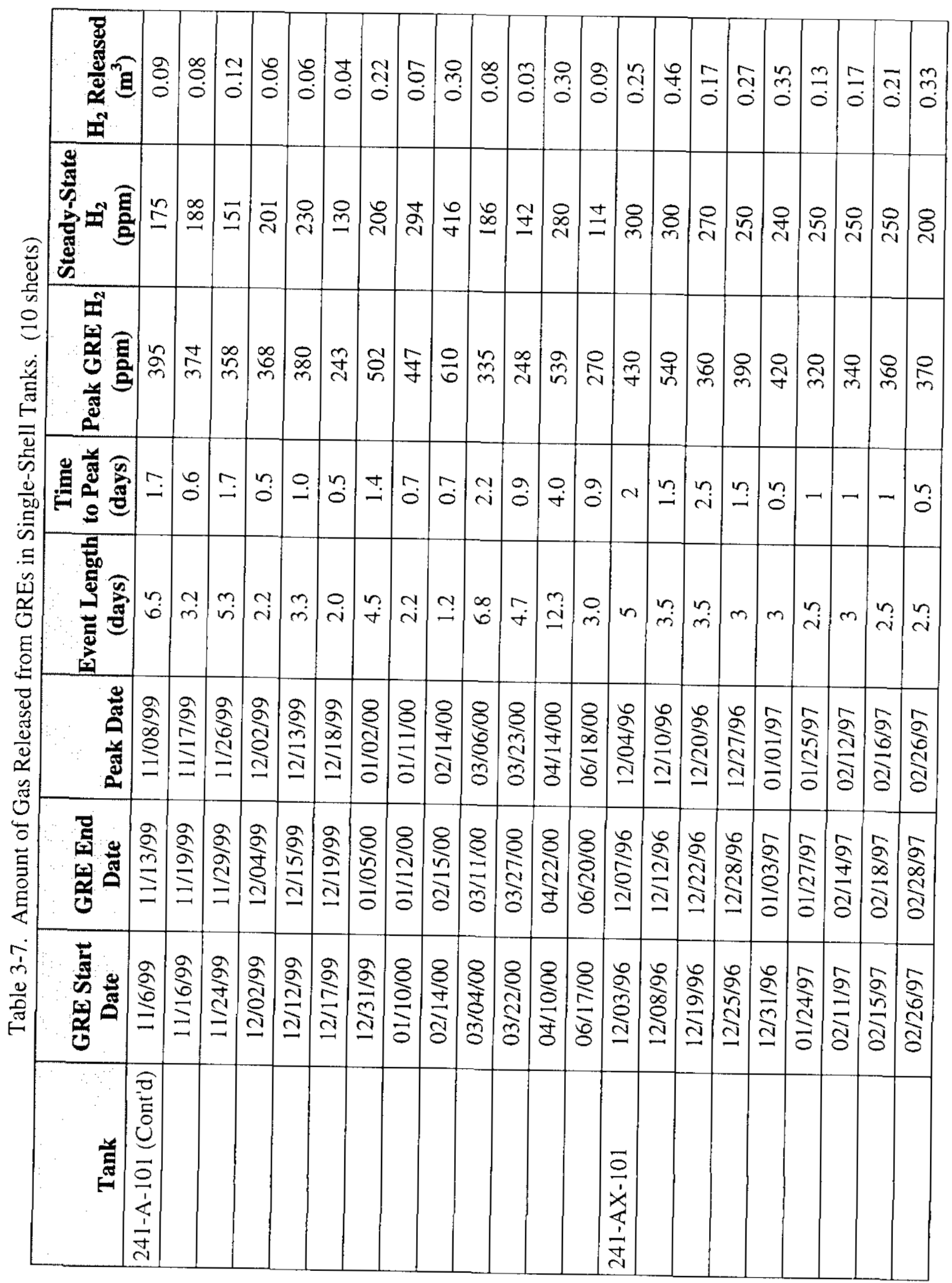




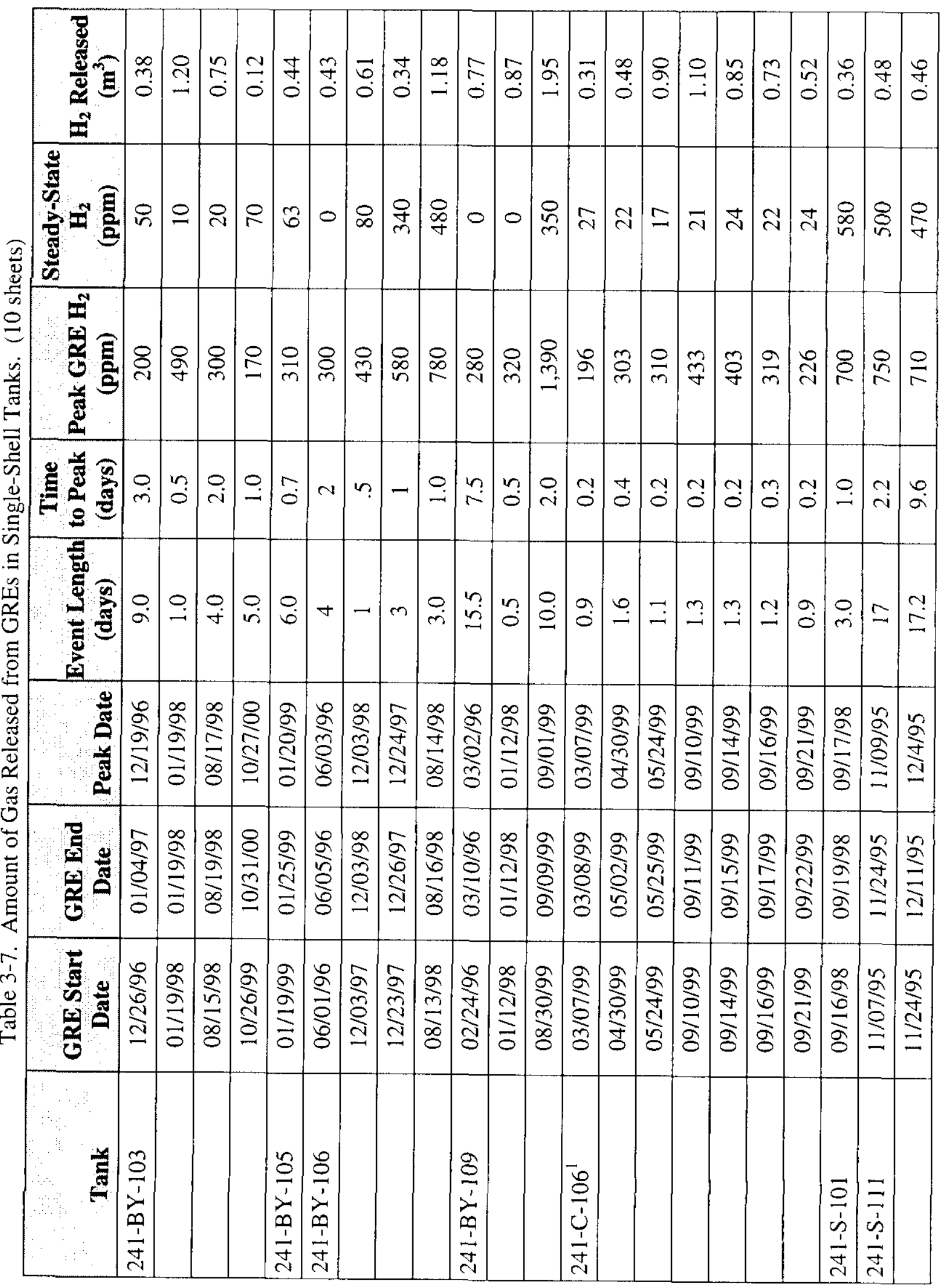




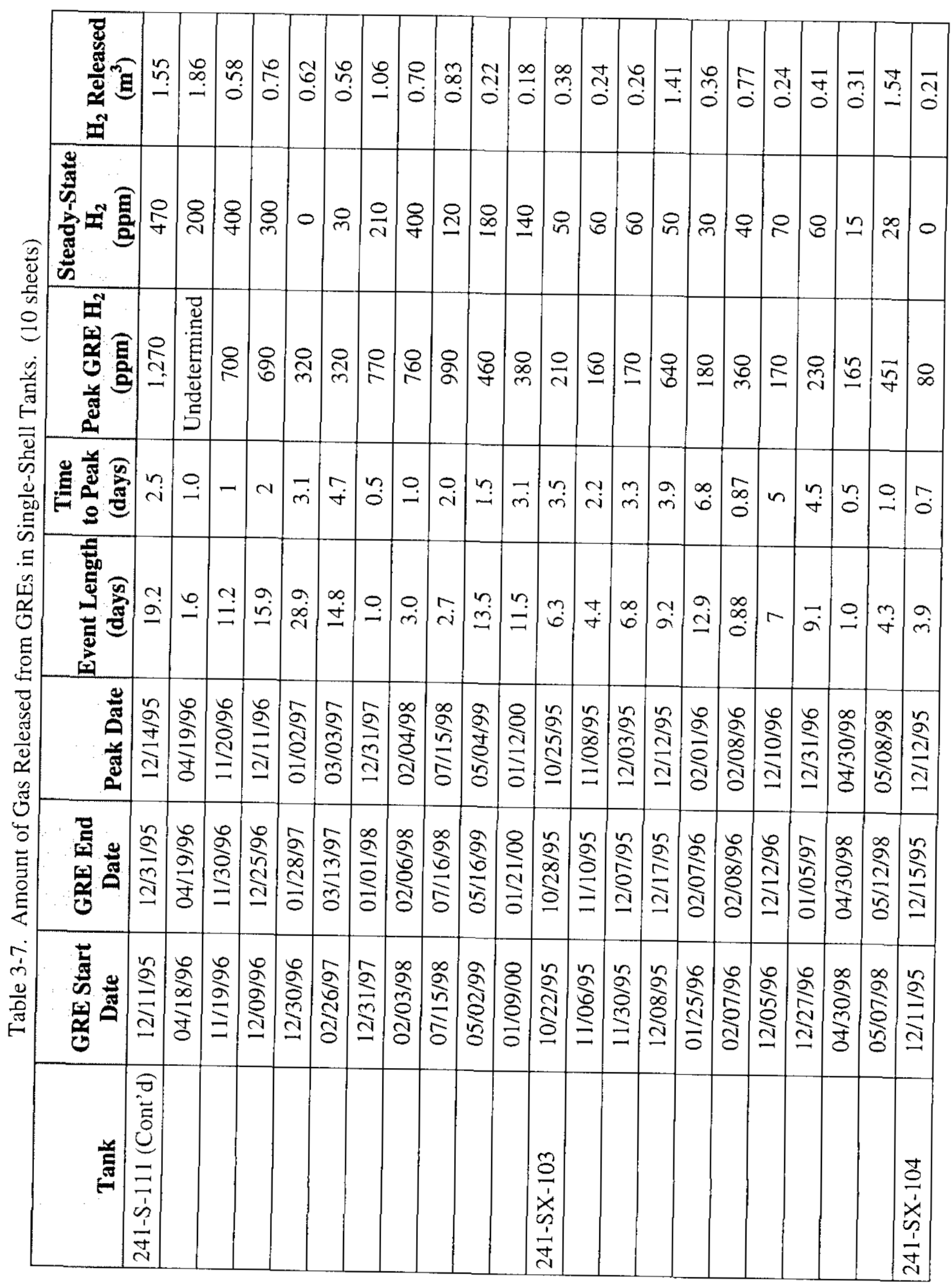




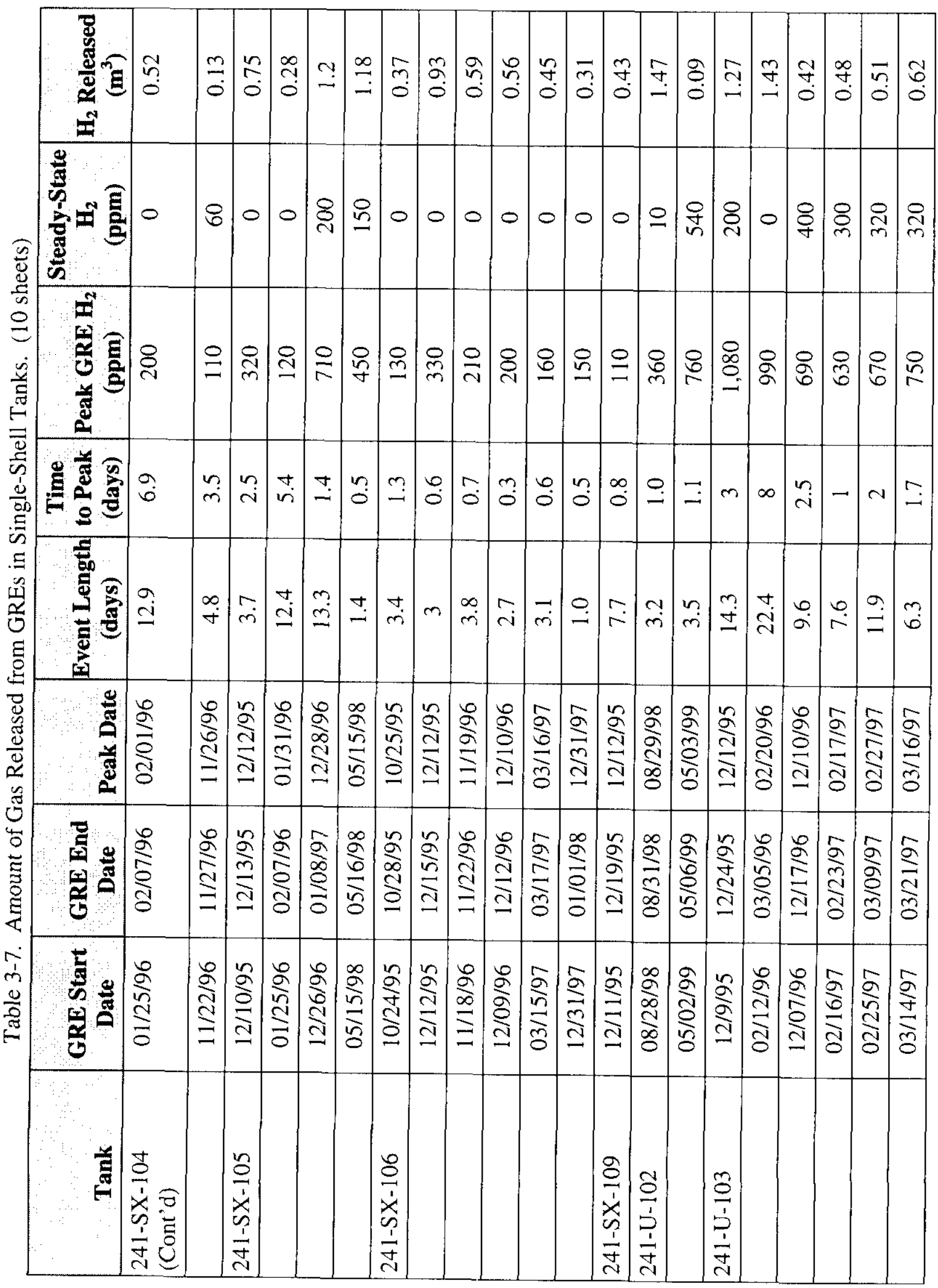


HNF-SD-WM-TI-797 Rev. 5

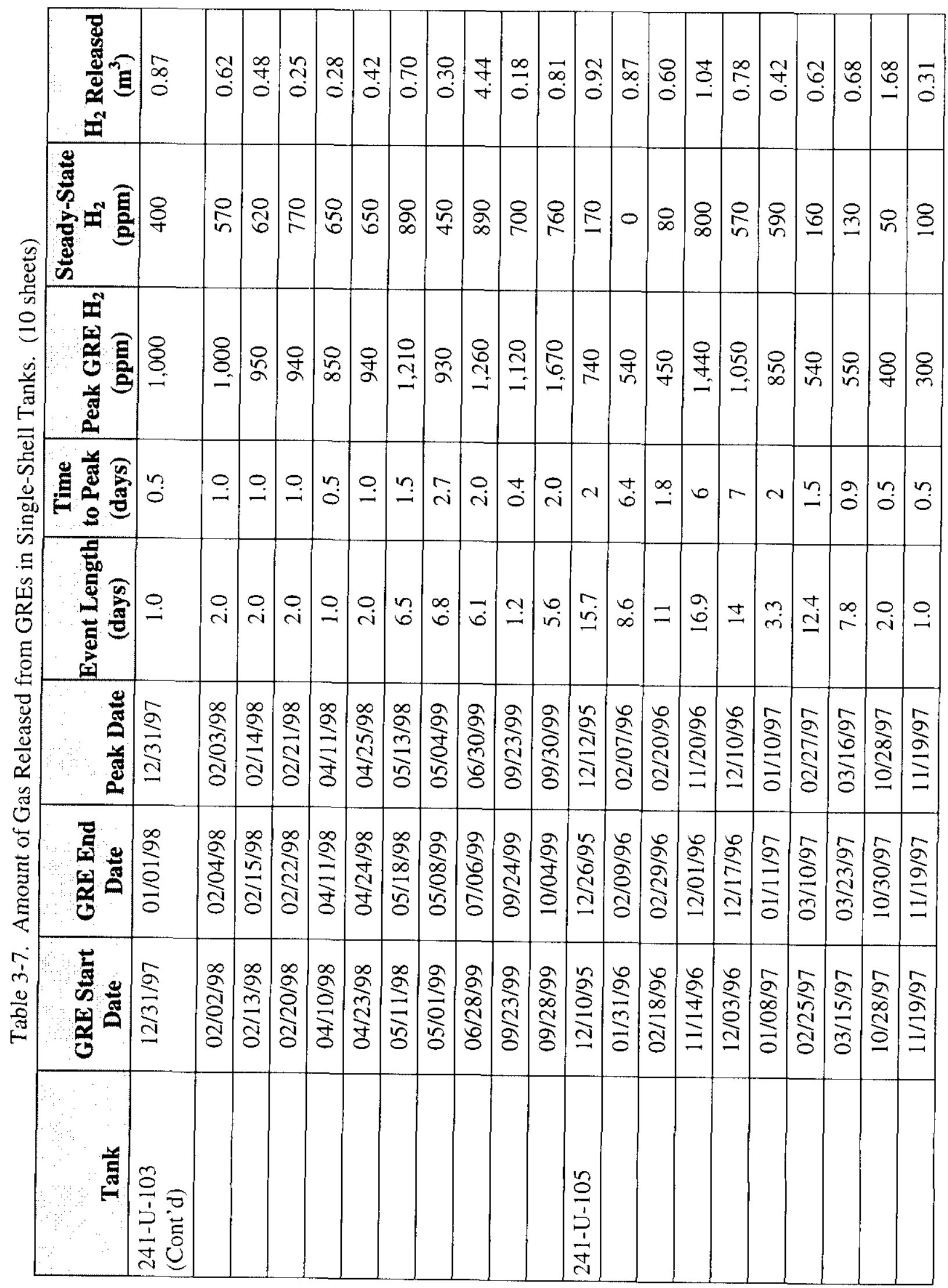


HNF-SD-WM-TI-797 Rev. 5

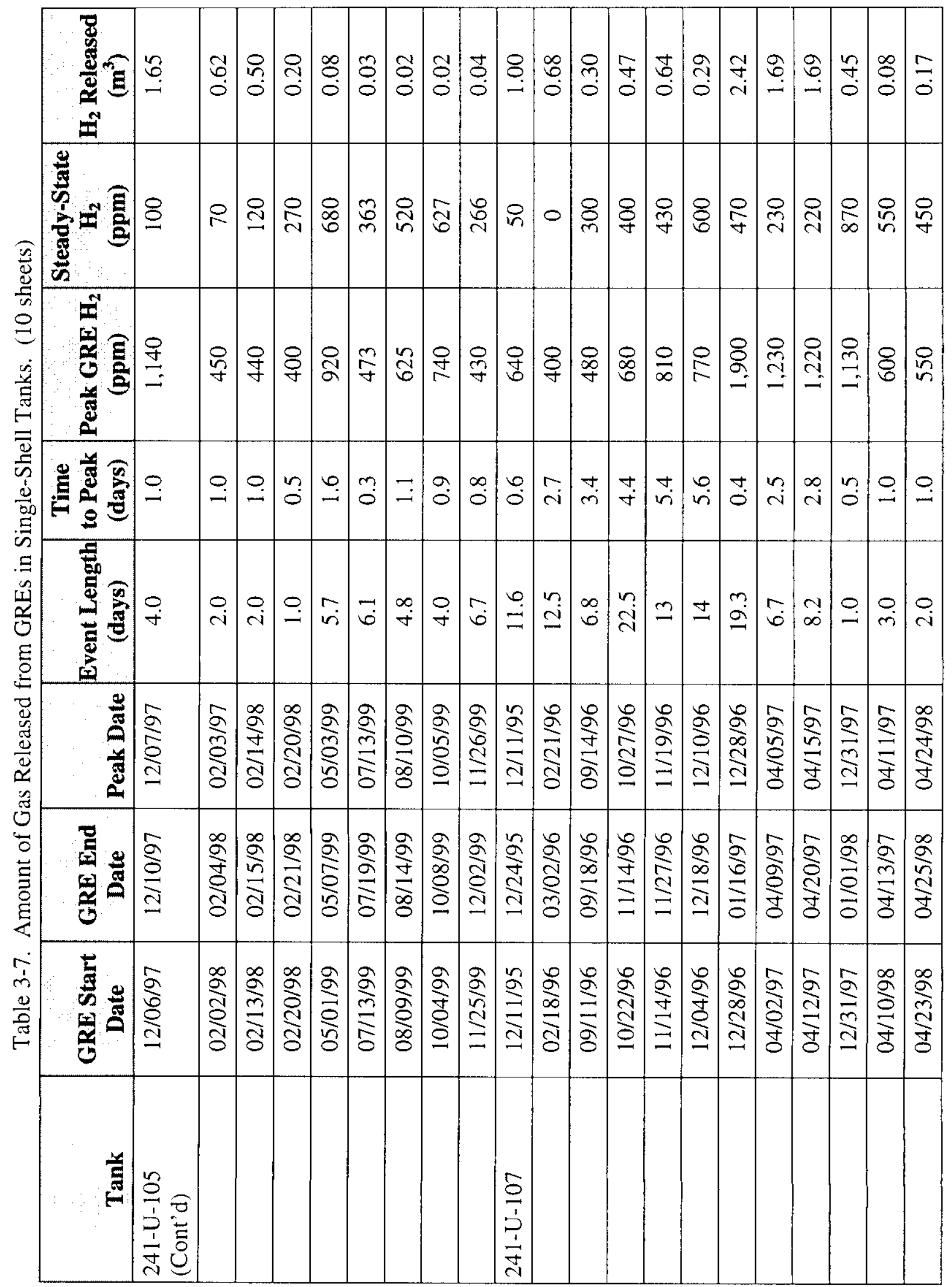




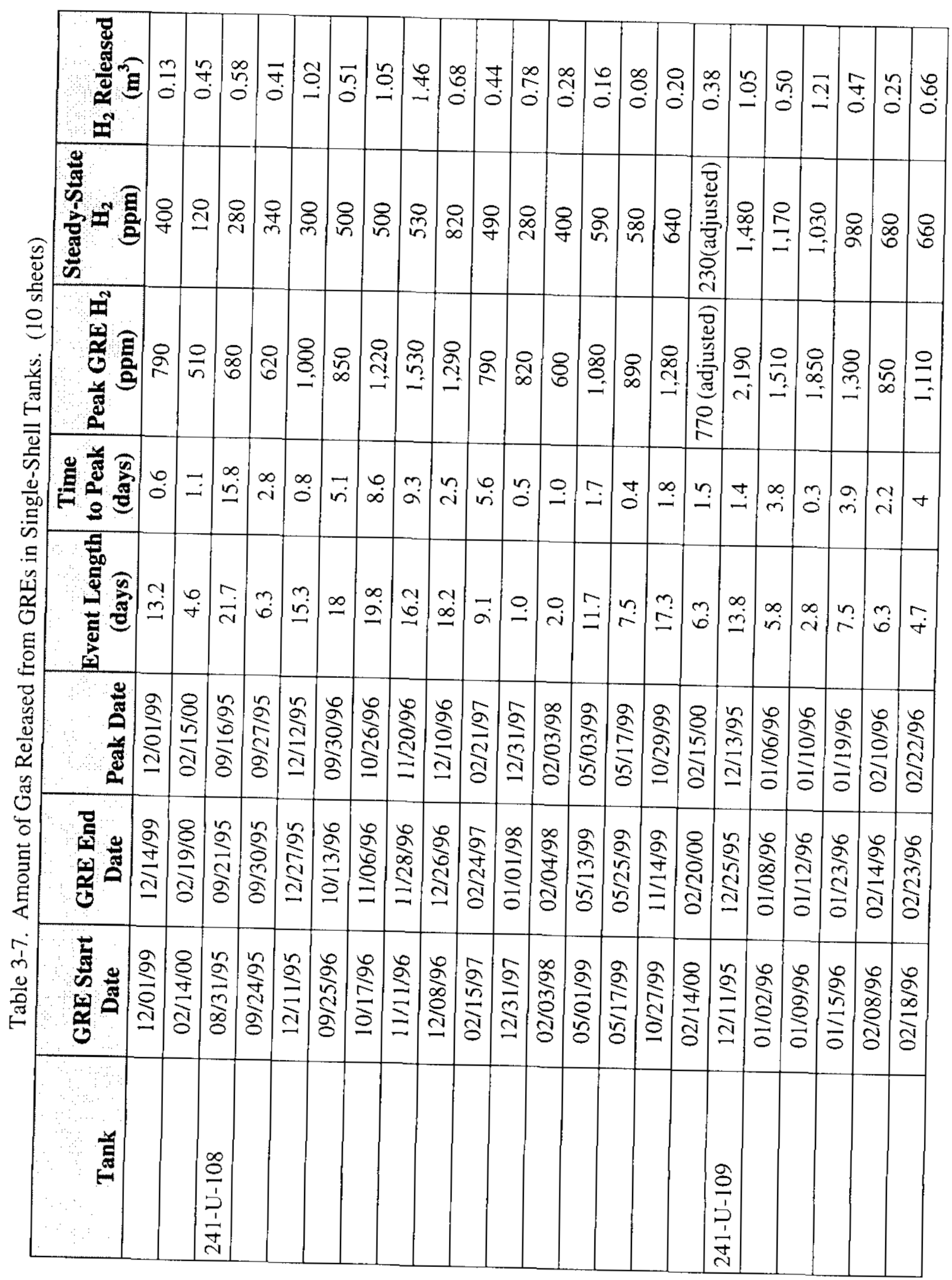


HNF-SD-WM-TI-797 Rev. 5

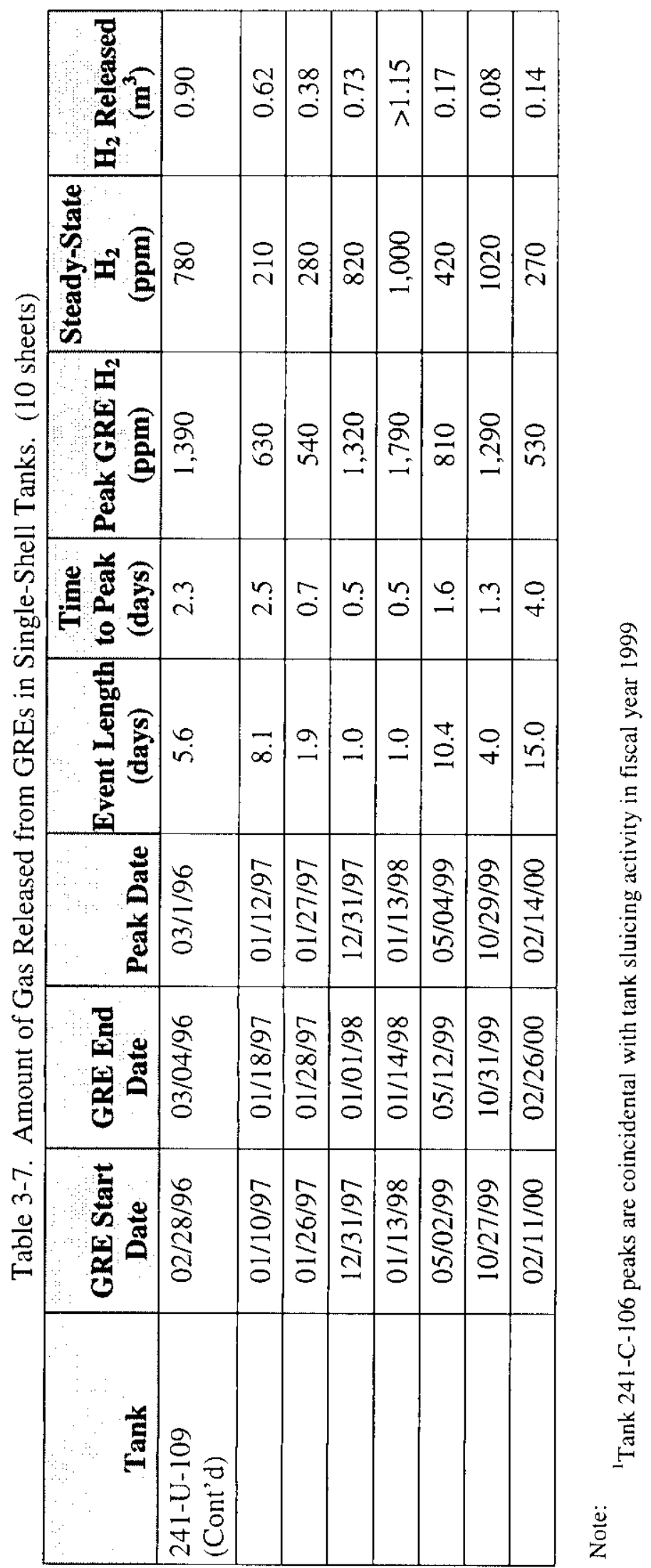




\subsection{SALTWELL PUMPING EFFECTS ON HYDROGEN CONCENTRATION}

Last year's report (McCain 1999a) described a "phenomenon" involving hydrogen concentration increases associated with saltwell pumping activities. First noted in tank 241-S-106, it was apparent that the dynamics of liquid removal from several SSTs resulted in an elevation of gas concentrations in rough synchrony with the pumping efficiency. Similar behavior has now been observed in tanks 241-S-102, 241-S-106, 241-SX-104, 241-U-102, 241-U-103, 241-U-105, and 241-U-109. A study was conducted (McCain 2000) to evaluate this behavior as it might relate to simplifying regulations affecting saltwell pumping. Sections 3.4 .1 and 3.4.2 describe the results of this study.

\subsubsection{Hydrogen Gas Behavior in Response to Saltwell Pumping Activity}

Saltwell pump running times were reviewed in correlation to hydrogen gas concentrations for the last two years. Thirty-two identifiable pumping termination events in eight SSTs were used as reference points for hydrogen concentration increases or decreases. Of the 32 events, the hydrogen concentration decreased 27 times and increased only five times. These observations support the hypothesis that rising hydrogen concentrations can be controlled merely by stopping pumping operations. A study of the five events that produced increased hydrogen concentrations determined that the maximum observed rate of concentration increase was 0.07 volume percent per day with a maximum observed duration of 17 days. These data suggest that a tank's hydrogen concentration might climb by 1.2 volume percent even after pumping is terminated. This rise in flammable gas concentration, added to the steady-state concentration observed in SSTs, is still well below the control point of 25 percent of the LFL.

\subsubsection{Pump Pit Monitor Redundancy to SHMS Instrumentation}

Section 1 of this document states that one of the principal reasons SHMS instrumentation is installed on a tank is to monitor flammable gas behavior during waste movement. Interim stabilization activities involve moving pumpable waste liquids. Tanks that have been identified as having significant quantities of pumpable waste generally are equipped with SHMS. Supplemental monitoring equipment has been used to measure the flammable gas concentration in the space directly over the tank (the pump pit). These pits house the pumping mechanism and are interconnected with the dome headspace. McCain (2000) compared the data from the two measurement systems and found that they tend to produce readings congruent with each other; i.e., the concentrations rise and fall in the same time intervals. Vapor grab samples were taken from the pump pits of tanks 241-U-102, 241-U-103, and 241-U-105 during pumping operations and analyzed through mass spectrometry. The results (see Table 3-8) demonstrate that the SHMS are quite accurate in determining hydrogen concentration in the pump pits, even though the sample heads are extended down into the dome space of the tank. Identifying this redundancy is a potential cost saving discovery. 
Table 3-8. Comparison of Monitoring Results with Pump Pit Vapor Samples.

\begin{tabular}{|l|c|c|}
\hline \multicolumn{1}{|c|}{ TANK } & $\begin{array}{c}\text { Pump Pit Hydrogen from } \\
\text { Grab Sample (ppm) }\end{array}$ & $\begin{array}{c}\text { Dome Space Hydrogen from } \\
\text { SHMS (ppm) }\end{array}$ \\
\hline $241-\mathrm{U}-102$ & 2,880 & 3,060 \\
\hline $241-\mathrm{U}-103$ & 3,000 & 2,940 \\
\hline $241-\mathrm{U}-105$ & 1,600 & 1,411 \\
\hline
\end{tabular}

\subsection{VAPOR GRAB SAMPLING}

In previous years, vapor grab samples were taken periodically to confirm SHMS hydrogen readings and to obtain additional information about other gases in the tanks. This year's engineering task plan (McCain 1999b) has no such sampling requirement. Five years of grab sampling have verified that SHMS instrumentation accurately determines flammable gas concentrations. The three grab samples detailed in Table 3-8 were similar to those taken in previous years. They were taken to determine flammable gas concentrations in the pump pit of three tanks being saltwell pumped. All grab sample results since 1994 are detailed in Appendix B. Except for tanks 241-AX-103 and 241-C-106, all tanks with SHMS were vapor grab sampled since July 1, 1998. Tank 241-U-105 had the highest percentage of the LFL at 3.8 percent. The next highest was tank $241-\mathrm{U}-107$ at 1.7 percent of the LFL. Previous measurements of all passively ventilated tanks showed flammable gas concentrations above 1 percent of the LFL for 27 tanks.

\subsection{SUMMARY OF SHMS MONITORING}

As discussed previously, continuous monitoring of a tank's hydrogen concentration is performed using SHMS. Most of the tanks being continuously monitored have a SHMS-B, which has two Whittaker ${ }^{\mathrm{TM}}$ electrochemical cells. Tank 241-AN-104 has a SHMS-C, which adds a GC.

Tanks 241-C-106 and 241-AY-102 also have SHMS-C cabinets with GCs. A SHMS-D has been installed on the exhaust vents of AN and AW tank farms. Note that tanks 241-BY-106 and 241-BY-109 have SHMS-D cabinets but lack ammonia monitors. The SHMS-D can measure both hydrogen and ammonia. The ammonia results are shown in Appendix D. The various monitoring systems are described fully in Section 2.0. Table 3-9 lists the tank, the type of SHMS, the date the original SHMS was installed, and the maximum hydrogen reading the SHMS has measured. When a SHMS type has been modified, the installation date for the latest configuration is listed in the second column. Most of the maximum readings occurred during GREs. Tanks 241-SX-101, 241-SX-102, and 241-T-1 10 have not exhibited any GRE behavior to date, and the maximums listed are maximum steady-state readings. Appendix A contains plots of data from the SHMS. 
HNF-SD-WM-TI-797 Rev. 5

Table 3-9. Maximum SHMS Readings. (2 sheets)

\begin{tabular}{|c|c|c|c|c|}
\hline Tank & SHMS Type & $\begin{array}{l}\text { Date Original } \\
\text { SHMS Installed }\end{array}$ & $\begin{array}{c}\text { Maximum } \mathbf{H}_{2} \\
\text { Reading } \\
\text { (ppm) }\end{array}$ & $\begin{array}{l}\text { Date of } \\
\text { Maximum } \\
\text { Reading }\end{array}$ \\
\hline $241-A-101$ & SHMS-E+ (1 1/97) & March 1995 & 837 & $02 / 07 / 99$ \\
\hline $241-\mathrm{AN}-101$ & SHMS-E+ & June 1997 & 330 & $05 / 11 / 98$ \\
\hline 241-AN-103 & SHMS-B & October 1994 & 3,000 & $08 / 22 / 95$ \\
\hline $241-\mathrm{AN}-104$ & SHMS-C & October 1994 & 5,900 & $05 / 03 / 96$ \\
\hline $241-\mathrm{AN}-105^{1}$ & SHMS-B & October 1994 & 17,000 & $08 / 21 / 95$ \\
\hline $241-\mathrm{AN}-107$ & SHMS-B & February 1998 & 290 & $04 / 30 / 00$ \\
\hline AN Farm Stack & SHMS-D & June 1996 & 1,040 & $07 / 28 / 99$ \\
\hline $241-A W-101^{1}$ & SHMS-B & September 1994 & 8,800 & $10 / 04 / 94$ \\
\hline AW Farm Stack & SHMS-D & June 1996 & 490 & $07 / 20 / 99$ \\
\hline $241-\mathrm{AX}-101$ & SHMS-B & March 1995 & 540 & $12 / 10 / 96$ \\
\hline $241-\mathrm{AX}-103$ & SHMS-B & March 1995 & 380 & $11 / 22 / 96$ \\
\hline $241-\mathrm{AY}-102$ & SHMS-C & March 1997 & 320 & $06 / 27 / 98$ \\
\hline $241-A Z-101$ & SHMS-E $^{1}$ & February 1998 & 750 & $04 / 18 / 98$ \\
\hline $241-A Z-102$ & SHMS-E ${ }^{1}$ & February 1998 & 1,500 & $12 / 09 / 99$ \\
\hline $241-B-111$ & SHMS-E+ & May 2000 & 150 & $06 / 21 / 00$ \\
\hline $241-B Y-103$ & SHMS-B & July 1995 & 770 & $11 / 27 / 96$ \\
\hline 241-BY-105 & SHMS-E+ & March 1998 & 310 & $01 / 20 / 99$ \\
\hline $241-\mathrm{BY}-106$ & $\begin{array}{l}\text { SHMS-D (w/o } \\
\text { ammonia monitor) }\end{array}$ & July 1995 & 880 & $01 / 05 / 96$ \\
\hline $241-B Y-109$ & $\begin{array}{l}\text { SHMS-D (w/o } \\
\text { ammonia monitor) }\end{array}$ & July 1995 & 1,770 & $02 / 03 / 00$ \\
\hline $241-C-106$ & SHMS-C & March 1997 & 756 & $05 / 16 / 97$ \\
\hline $241-S-101$ & SHMS-E & March 1998 & 1,120 & $07 / 23 / 99$ \\
\hline $241-\mathrm{S}-102$ & SHMS-B & March 1995 & 3,780 & $05 / 20 / 96$ \\
\hline $241-S-106$ & SHMS-E+ & March 1998 & 2,585 & $05 / 20 / 99$ \\
\hline $241-S-107$ & SHMS-B & March 1998 & 370 & $11 / 22 / 98$ \\
\hline $241-S-109$ & SHMS-E+ & March 1998 & 185 & $06 / 13 / 98$ \\
\hline $241-S-111$ & SHMS-B & March 1995 & 1,270 & $12 / 14 / 95$ \\
\hline $241-S-112$ & SHMS-B & March 1995 & 490 & $08 / 22 / 95$ \\
\hline $241-S X-101$ & SHMS-B & March 1995 & 400 & $08 / 22 / 95$ \\
\hline $241-\mathrm{SX}-102$ & SHMS-B & March 1995 & 740 & $11 / 12 / 96$ \\
\hline $241-S X-103$ & SHMS-E+ (3/98) & March 1995 & 640 & $02 / 12 / 95$ \\
\hline
\end{tabular}


HNF-SD-WM-TI-797 Rev. 5

Table 3-9. Maximum SHMS Readings. (2 sheets)

\begin{tabular}{|c|c|c|c|c|}
\hline Tank & SHMS Type & $\begin{array}{l}\text { Date Original } \\
\text { SHMS Installed }\end{array}$ & $\begin{array}{c}\text { Maximum } \mathbf{H}_{2} \\
\text { Reading } \\
\text { (ppm) }\end{array}$ & $\begin{array}{c}\text { Date of } \\
\text { Maximum } \\
\text { Reading }\end{array}$ \\
\hline 241-SX-104 & SHMS-B & March 1995 & 580 & $08 / 22 / 95$ \\
\hline $241-\mathrm{SX}-105$ & SHMS-B & March 1995 & 710 & $12 / 28 / 96$ \\
\hline $241-S X-106$ & SHMS-B & March 1995 & 560 & $08 / 17 / 97$ \\
\hline 241-SX-109 & SHMS-B & March 1995 & 890 & $12 / 15 / 99$ \\
\hline $241-S Y-101^{2}$ & SHMS (3 units) & March 1992 & 50,000 & $09 / 03 / 92$ \\
\hline 241-SY-102 & SHMS-E+ & March 1998 & 238 & $12 / 18 / 99$ \\
\hline 241-SY-103 & SHMS-B & May 1992 & 5,720 & $05 / 08 / 98$ \\
\hline $241-\mathrm{T}-110$ & SHMS-B & March 1995 & 500 & $08 / 31 / 99$ \\
\hline $24 \mathrm{I}-\mathrm{U}-102$ & SHMS-B & May 1998 & 3,280 & $02 / 24 / 00$ \\
\hline $241-\mathrm{U}-103$ & SHMS-B & March 1995 & 4,870 & $11 / 02 / 99$ \\
\hline $241-\mathrm{U}-105$ & SHMS-E+ (5/98) & March 1995 & 3,680 & $10 / 24 / 96$ \\
\hline $241-U-107$ & SHMS-B & March 1995 & 1,900 & $12 / 28 / 96$ \\
\hline $241-U-108$ & SHMS-B & March 1995 & 3,280 & $02 / 25 / 96$ \\
\hline 241-U-109 & SHMS-B & March 1995 & 4,930 & $03 / 23 / 00$ \\
\hline
\end{tabular}

Notes:

'GCS installed (April 1996)

${ }^{2}$ GMS-1 and GMS-2 also installed (November 1992) 
HNF-SD-WM-TI-797 Rev. 5

This page intentionally left blank. 
HNF-SD-WM-TI-797 Rev. 5

\subsection{SHMS CABINET REMOVAL}

The Tri-Party Agreement (Ecology et al. 1994) Milestone M-40-00 required design, procurement, and fabrication of SHMS for all FGWL tanks. The current number of FGWL tanks is 25. Subsequent studies provided justification for installing SHMS on non-FGWL tanks. These include the following:

- Tanks with the calculated potential to exceed 100 percent of the LFL in the head space caused by gas retention and an episodic release

- Tanks scheduled for saltwell pumping

- DSTs that receive supernatant from saltwell pumping with the potential for gas retention and episodic release

- Project tanks (e.g., W-320) with the potential for gas retention and episodic release

- Aging waste tanks with high radiolytic gas generation rates.

Starting with tank 241-SY-101 in May 1992, SHMS were installed on 41 tanks and on exhauster vents for the $\mathrm{AN}$ and $\mathrm{AW}$ tank farms. Improvements and enhancements in data retrieval and management were implemented, resulting in an extensive network providing hundreds of thousands of recorded data points available for review every month. Continual monitoring combined with monthly, quarterly, and annual reports provides flammable gas concentration information formatted to allow data trending and comparisons.

Two documents were developed to deal with the operation of the SHMS. First, a technical basis report (Estey 1998) was issued that provides the basis for the alarm limit of 6,250 ppm for 25 percent of the LFL as a conservative monitoring value for hydrogen; this paper also discusses the role of other species on the LFL. The Engineering Test Plan (McCain 1999b) gives the guidelines for organizational responsibilities for the operation and maintenance of the SHMS. Although the technical basis document provides guidelines for removing a SHMS from a tank, the collection of data and operational history since the document was issued provided an opportunity to reevaluate the need to monitor selected tanks.

The reevaluation of SHMS needs was presented to the U.S. Department of Energy, Office of River Protection in December 1999 (LMHC 1999) as an implementation of field optimization. The proposal was to place 10 SHMS in a standby mode and remove 11 other SHMS completely. The standby mode option was selected for those tanks that may require flammable gas monitoring in the future because of waste movement activities such as transfers and saltwell pumping. The Office of River Protection responded in January 2000 with Performance Initiative ORP3.2.3 (DOE 2000). This initiative directed that SHMS on seven tanks be placed in a standby mode: 241-AZ-102, 241-S-101, 241-S-107, 241-S-109, 241-S-111, 241-S-112 and 241-SX-102. Seven additional units are to be removed from the following tanks: 241-AX-103, 241-BY-109, 241-C-106, 241-SX-104, 241-SX-109, 241-T-110, and the AW stack monitor SHMS. The SHMS unit on tank 241-SX-106 was to remain in service until interim stabilization is declared. Table 4-1 shows the status of the SHMS equipment for these tanks, along with the date the last 
hydrogen data was available. The charts in Appendix A also indicate the date each SHMS cabinet was isolated.

Table 4-1. SHMS Removal/Standby Status as of June 30, 2000.

\begin{tabular}{|l|l|c|}
\hline \multicolumn{1}{|c|}{ Tank } & \multicolumn{1}{|c|}{ SHMS Disposition } & Last Data Date \\
\hline $241-\mathrm{AX}-103$ & Removed & $08 / 01 / 97$ \\
\hline AW Stack Monitor & Removed & $02 / 14 / 00$ \\
\hline $241-\mathrm{AZ}-102$ & Standby & $02 / 13 / 00$ \\
\hline $241-\mathrm{BY}-109$ & Removed & $02 / 14 / 00$ \\
\hline $241-\mathrm{C}-106$ & Removed & $06 / 30 / 00$ \\
\hline $241-\mathrm{S}-101$ & Standby & $02 / 14 / 00$ \\
\hline $241-\mathrm{S}-107$ & Standby & $02 / 14 / 00$ \\
\hline $241-\mathrm{S}-109$ & Standby & $02 / 15 / 00$ \\
\hline $241-\mathrm{S}-111$ & Standby & $02 / 16 / 00$ \\
\hline $241-\mathrm{S}-112$ & Standby & $02 / 16 / 00$ \\
\hline $241-\mathrm{SX}-102$ & Standby & $02 / 16 / 00$ \\
\hline $241-\mathrm{SX}-104$ & Removed & $06 / 08 / 00$ \\
\hline $241-\mathrm{SX}-106$ & Removed & $06 / 06 / 00$ \\
\hline $241-\mathrm{SX}-109$ & Removed & $02 / 16 / 00$ \\
\hline $241-\mathrm{T}-110$ & Removed & $02 / 13 / 00$ \\
\hline
\end{tabular}




\subsection{SUMMARY OF MONITORING BY OTHER SYSTEMS}

Some tanks are monitored using other systems in addition to the Whittaker ${ }^{\mathrm{TM}}$ cells in the SHMS.

\subsection{GAS MONITORING SYSTEM-2}

The GMS-2 has been sampling from the vent header (riser 7A) of tank 241-SY-101 since November 1992. This system is a combination of an FTIR, two hydrogen-specific reduction gas analysis GCs, and one photoacoustic IR analyzer. The FTIR measures $\mathrm{NH}_{3}$ and $\mathrm{N}_{2} \mathrm{O}$, one GC measures low concentrations of hydrogen, the other $\mathrm{GC}$ has a dual column and can measure both low and high concentrations of hydrogen, and the IR analyzer monitors the SY farm exhaust stack for ammonia. The GCs, FTIR, and IR analyzer are used to support mixer pump administrative controls. The data are sent to the tank 241-SY-101 DACS.

Steady-state concentrations before mixer pump operation were measured using this system (Wilkins 1993). Table 5-1 lists monthly averages leading up to the last major GRE and the peak concentrations during the last major GRE in this tank. Mixer pump operations began in July 1993. Gas concentration monthly averages during selected months after July 1993 also are listed in Table 5-1. Significant quantities of waste were transferred out of tank 241-SY-101 in December 1999 and in January and February 2000. The volumes transferred out in these months were $84 \mathrm{kgal}, 241 \mathrm{kgal}$, and $154 \mathrm{kgal}$, respectively. The bottom two rows of Table $5-1$ show pretransfer and post-transfer gas concentrations for these mitigation activities. The complete database of tank 241-SY-101 gas data is archived regularly. A quarterly report is issued containing much more detail than this document provides. Please refer to Conner and Koreski 1999, 2000a, and 2000b.

\subsection{GAS CHARACTERIZATION SYSTEM}

GCSs are installed and operating on tanks 241-AW-101 and 241-AN-105 in addition to SHMSs. The headspaces of these tanks have had hydrogen concentrations greater than $6,250 \mathrm{ppm}$, the action level for hydrogen grab sampling. These high hydrogen concentrations occurred during GREs. To learn more about the gases emitted from these tanks, GCSs were installed; they began recording data in April 1996. A GCS has a GC to measure hydrogen, another GC to measure nitrous oxide and methane, and an FTIR to measure ammonia. Appendix A has charts that depict the steady-state gas measurements from the system. The GCS readings are consistent with the results from the grab samples. The difference between continuous hydrogen measurements measured with a SHMS and the GCS is usually less than $150 \mathrm{ppm}$. Table 5-2 lists the peak concentrations measured with the GCS during the GREs that have occurred since the systems were installed on the tanks. Hydrogen, nitrous oxide, and methane tend to peak together, but ammonia tends to peak about 3 hours later. 
HNF-SD-WM-TI-797 Rev. 5

Table 5-1. Tank 241-SY-101 Gas Monitoring.

\begin{tabular}{|c|c|c|c|c|}
\hline Tank Condition & Date & $\begin{array}{c}\mathbf{H}_{2} \\
(\mathbf{p p m})\end{array}$ & $\begin{array}{c}\mathrm{N}_{2} \mathrm{O} \\
(\mathrm{ppm})\end{array}$ & $\begin{array}{c}\mathrm{NH}_{3} \\
(\mathrm{ppm})\end{array}$ \\
\hline Steady-state & $2 / 93$ & 26 & 28 & 34 \\
\hline Steady-state & $3 / 93$ & 16 & 15 & 34 \\
\hline Steady-state & $4 / 93$ & 20 & 22 & 36 \\
\hline Steady-state & $5 / 93$ & 21 & 24 & 49 \\
\hline Steady-state & $6 / 93$ & 16 & 17 & 64 \\
\hline GRE & $6 / 26 / 93$ & 31,200 & 32,500 & 13,000 \\
\hline Steady-state & $7 / 93$ & 24 & 27 & 68 \\
\hline Steady-state & $1 / 94$ & 30 & 31 & 38 \\
\hline Steady-state & $1 / 95$ & 36 & 52 & 32 \\
\hline Steady-state & $1 / 96$ & 35 & 46 & 28 \\
\hline Steady-state & $9 / 96$ & 40 & 49 & 39 \\
\hline Steady-state & $1 / 97$ & 34 & 44 & 28 \\
\hline Steady-state & $5 / 97$ & 42 & 38 & 30 \\
\hline Steady-state & $11 / 10 / 97$ & 21 & 35 & 31 \\
\hline Steady-state & $3 / 29 / 98$ & 11 & 12 & 29 \\
\hline Steady-state & $12 / 9 / 98$ & 20 & 17 & 44 \\
\hline Steady-state & $6 / 22 / 99$ & 18 & 15 & 66 \\
\hline Steady-state & $12 / 1 / 99$ & 38 & 20 & 54 \\
\hline Steady-state & $3 / 15 / 00$ & 261 & 161 & 72 \\
\hline
\end{tabular}


HNF-SD-WM-TI-797 Rev. 5

Table 5-2. GCS Results during GREs (ppm)

\begin{tabular}{|c|c|c|c|c|c|}
\hline Tank & $\begin{array}{l}\text { GRE } \\
\text { Date }\end{array}$ & $\begin{array}{c}\text { Peak } \\
\text { Hydrogen } \\
\text { (ppm) }\end{array}$ & $\begin{array}{c}\text { Peak } \\
\text { Nitrous Oxide } \\
(\text { ppm })\end{array}$ & $\begin{array}{c}\text { Peak } \\
\text { Methane } \\
\text { (ppm) }\end{array}$ & $\begin{array}{c}\text { Peak } \\
\text { Ammonia } \\
(\text { ppm })\end{array}$ \\
\hline \multirow[t]{12}{*}{$241-\mathrm{AN}-105$} & $05 / 30 / 96$ & 14,500 & 2,850 & 150 & 610 \\
\hline & $04 / 05 / 97$ & 6,980 & 1,496 & 0 & 119 \\
\hline & $09 / 25 / 97$ & 950 & 124 & 11 & 27 \\
\hline & $11 / 22 / 97$ & 1,030 & 170 & 12 & 78 \\
\hline & $12 / 31 / 97$ & 3,940 & 763 & 53 & 113 \\
\hline & $09 / 01 / 98$ & 1,870 & 564 & 37 & 481 \\
\hline & $03 / 07 / 99$ & 760 & Not available & Not available & 565 \\
\hline & $05 / 02 / 99$ & 182 & 51 & 0 & 579 \\
\hline & $07 / 28 / 99$ & 7,100 & 1,958 & 94 & 69 \\
\hline & $08 / 02 / 99$ & 7,620 & 977 & 64 & 60 \\
\hline & $10 / 27 / 99$ & 180 & 63 & 20 & 65 \\
\hline & $01 / 01 / 00$ & 186 & 52 & 21 & 29 \\
\hline \multirow[t]{7}{*}{ 241-AW-101 } & $05 / 14 / 96$ & 1,455 & 33 & 0 & 15 \\
\hline & $05 / 06 / 96$ & 2,500 & 86 & 2 & 19 \\
\hline & $04 / 21 / 98$ & 398 & 58 & 10 & 260 \\
\hline & $06 / 24 / 98$ & 450 & 145 & 5 & 330 \\
\hline & $07 / 04 / 98$ & \multicolumn{4}{|c|}{ Non-GCS system used to announce peak. Not confirmed by GCS. } \\
\hline & $01 / 16 / 00$ & 210 & 18 & 0 & 15 \\
\hline & $04 / 22 / 00$ & 2,092 & 19 & 0 & 8 \\
\hline
\end{tabular}

\subsection{GAS CHROMATOGRAPH RESULTS}

The following tanks have gas chromatographs installed in conjunction with the SHMS cabinets: 241-A-101, 241-AN-101, 241-AN-104, 241-AY-102, 241-B-111, 241-BY-105, 241-C-106, 241-S-106, 241-S-109, 241-SX-103, 241-SY-102, and 241-U-105. The GC has a much higher sensitivity and accuracy than the SHMS at low hydrogen concentrations. The system has been very reliable. Consequently, the GC data are used to provide GRE data for this report. Data for all these tanks are found in Appendix A. 


\subsection{AMMONIA MONITORING OF TANK FARM EXHAUST VENTS AND INDIVIDUAL TANKS}

Ammonia and hydrogen are monitored at the exhaust vents of the AW and AN tank farms, while ammonia is monitored with photoacoustic IR multi-gas monitors on tanks 241-A-101, 241-AN-101, 241-BY-105, 241-S-106, 241-S-109, 241-SX-103, 241-SY-102, and 241-U-105. The data for these tanks are found in Appendix A. The highest ammonia concentration in 2000 was detected in tank 241-SY-102 on March 1, with a concentration of 7,390 ppm, well below the flammable concentration of about $150,000 \mathrm{ppm}$. This concentration was associated with a transfer of waste from tank 241-SY-101 to tank 241-SY-102. When the transfer stopped, the ammonia level immediately decreased. 


\subsection{HYDROGEN GENERATION RATE}

Previous revisions of this document contained a lengthy section on hydrogen generation. A recently released document $(\mathrm{Hu} 2000)$ presents the empirical rate equation model and rate calculations of hydrogen generation. The empirical rate equations were derived to estimate hydrogen generation based on chemical reaction, radiolysis of water and organic compounds, and corrosion processes.

Key components of the model include the discovery that both the thermal and radiolysis rates of hydrogen generation are temperature dependent and follow Arrhenius behavior. The thermal rate also is proportional to the total organic carbon and aluminate concentrations. The radiolysis rate is the product of the radiation dose rate and the hydrogen "G-value." This G-value divides the radiolysis contribution to hydrogen generation into water and organic radiolyses, which are affected by waste with a high nitrate or nitrite concentration or total organic carbon concentration, respectively. The G-value also is a function of temperature. The contribution of liner corrosion is a product of the liner corrosion rate and the wetted area inside the tank.

The final test of the model compared the hydrogen generation rate with field observed data for 28 tanks, both single- and double-shelled. For most of these tanks, the calculated generation rate is within a factor of three. 
HNF-SD-WM-TI-797 Rev. 5

This page intentionally left blank. 


\subsection{FLAMMABLE GAS ACTION LEVELS FOR HANFORD WASTE TANKS}

The following sections define the flammable gas action level for Hanford Site waste tanks, the planned response if the action level is exceeded, and a summary of the occurrences in which the action level has been exceeded.

\subsection{DESCRIPTION OF ACTION LEVEL}

Tank Farm Operations is required by DOE Order 5480.4, Environmental Protection, Safety, and Health Protection Standards, to follow the guidelines provided within NFPA 69, Explosion Prevention Systems. This guideline requires systems that contain flammable gas and have the potential for an ignition source to be maintained at concentrations below 25 percent of the LFL of the gas or gas mixture. The exception to this limit is when automatic instrumentation with safety interlocks is provided, the combustible concentration shall be permitted to be maintained at or below 60 percent of the LFL.

Each Hanford Site tank generates a different composition of flammable gas. The fuel gases produced by the tanks are composed primarily of hydrogen, but they also can contain significant quantities of ammonia and methane. In addition to the fuel gases, the tanks also can produce nitrous oxide, which under certain conditions can enhance the flammability of the mixture. Monitoring for all the gases that can contribute to the flammable gas issue is cumbersome and expensive. For this reason, hydrogen - by far the dominant flammable gas of concern - was selected as the gas species to be monitored as the indicator when additional action is required.

To account for the effect of the other gases that may be present, the hydrogen concentration at which action is taken is adjusted (Estey 1998). The action level is set at 6,250 ppm of hydrogen. This concentration of hydrogen is equivalent to 25 percent of the LFL for the expected worst case gas mixture from a Hanford Site tank. This is the level at which additional characterization of the headspace gas and other mitigation measures would be considered. A recent study of flammability of Hanford Site waste gases (Mahoney et al. 2000) is currently being evaluated with the intention of raising this conservative action level closer to the actual 25 percent of LFL value (10,000 ppm).

\subsection{ACTION-LEVEL RESPONSE}

If a hydrogen vapor reading in a tank headspace exceeds $6,250 \mathrm{ppm}$, an engineering evaluation is to be performed (Estey 1998). The purpose of this evaluation is to determine whether the tank presents a serious safety issue and if mitigating the tank condition is necessary. This approach in deciding the need for mitigation is used because implementing the mitigation methods, such as installing and operating a mixer pump, is expensive and installing this type of equipment presents a substantial safety risk to the tank farm workers. 
A typical example of the recommendations resulting from the engineering evaluation of a gas release event is found in WHC-SD-WM-ER-524, Waste Tank 241-AN-105 Gas Release Response Recommendation (Minteer 1996). Note that this action plan is for an actively ventilated DST and portions of this plan would likely be different for a passively ventilated SST:

1. Improve tank monitoring and characterization capabilities to obtain the data necessary to lower uncertainties in the gas composition, gas release volume, and waste gas inventory determinations.

- Install a GCS

- Install a hydrogen/ammonia monitor in the ventilation system

- Obtain characterization data from void fraction meter, viscometer, and retained gas sampler tests

- Install an air flow meter

- Increase frequency of tank waste level measurements.

2. Optimize tank ventilation flows to ensure that dilution air flow is adequate to minimize the time required to reduce the flammable gas concentration following a release.

- Determine optimum tank air flow balance, considering any necessary dilution at the existing fan

- Provide air flow control capability for every tank in the farm and set flow rates to the optimum values

- For the interim, ensure FGWL tank air flows are maintained at or above $2.8 \mathrm{~m}^{3} / \mathrm{min}$ $\left(100 \mathrm{ft}^{3} / \mathrm{min}\right)$ (based on engineering judgement).

3. Ensure a low risk of igniting a flammable gas mixture to prevent ignition of the released gas if the LFL is exceeded.

- Evaluate need to deenergize or replace ventilation system heaters, and other options

- Evaluate need to replace ventilation fan with "sparkless" model, and other options

- Evaluate need to deenergize or replace any other potential ignition sources.

4. Determine the need for additional actions after subsequent gas release event data are obtained and evaluated. 


\subsection{SUMMARY OF GAS RELEASE EVENTS EXCEEDING THE ACTION LEVEL}

Other than the major gas release events recorded in tank 241-SY-101, three events in which the tank headspace flammable gas concentration exceeded the action level have been observed since the installation of SHMS units. Two events were observed in tank 241-AN-105 (both exceeded $14,000 \mathrm{ppm}$ hydrogen) and one in tank 241-AW-101 (approximately 8,800 ppm hydrogen). The flammable gas headspace concentration has not exceeded the action level in tank 241-SY-101 since installation of the mixer pump in July 1993.

Tanks 241-AN-105 and 241-AW-101 have undergone additional characterization as a result of these events. This characterization includes installing a GCS, sampling with the retained gas sampler, and taking measurements with the void fraction instrument and ball rheometer. 
HNF-SD-WM-TI-797 Rev. 5

This page intentionally left blank. 


\subsection{MAINTENANCE ISSUES AND ACTIONS PLANS FOR CONTINUED MONITORING}

Continued monitoring of the Watch List tanks and other tanks with a serious potential to exceed 25 percent of the LFL in the headspace will be accomplished using either the currently installed SHMS units, the GCSs, or portable systems that can be installed temporarily. Improvements to the existing systems are planned to correct operational problems encountered to date. The basis for tank monitoring and the duration of monitoring required is addressed in Estey (1998) and was still in effect for fiscal year 2000 .

\subsection{RELIABILITY OF SHMS INSTRUMENTATION}

Table 8-1 displays the accessibility of SHMS data from the various instrument systems from July 1, 1999, through June 30, 2000. To ensure the accuracy of the chart, the following steps were taken. For Whittaker ${ }^{\mathrm{TM}}$ Cell reliability, the operator round sheets were consulted for each week. If a reading was in either the high or low range cells, and the airflow was within the required ranges, the cell was considered operational for the day. The Whittaker ${ }^{\mathrm{TM}}$ Cell entries are defined as "SHMS" with a designation of the specific SHMS configuration (e.g., E+). All GCs or other measurement systems were evaluated in terms of days where data were available. Sometimes data may be missing for some days because the measurement system was shut down for calibration. This may appear to not be an accurate statement of reliability. However, when such a calibration activity precludes collection and availability of gas concentration data, the results are the same. Table $8-2$ provides a summary for each instrument type.

Table 8-1. SHMS Data System Reliability. (3 sheets)

\begin{tabular}{|l|c|c|c|}
\hline \multicolumn{1}{|c|}{ Tank System } & Days Available* & Days Unavailable & Percent Available \\
\hline A-101 SHMS-E & 356 & 10 & 97.3 \\
\hline GC & 330 & 36 & 90.2 \\
\hline PHOTO & 132 & 234 & 36.1 \\
\hline AN-101 SHMS-E+ & 366 & 0 & 100.0 \\
\hline GC & 286 & 80 & 78.1 \\
\hline PHOTO & 157 & 209 & 42.9 \\
\hline AN-103 SHMS-B & 366 & 0 & 100.0 \\
\hline AN-104 SHMS-C & 366 & 0 & 100.0 \\
\hline GC & 356 & 10 & 97.3 \\
\hline
\end{tabular}


HNF-SD-WM-TI-797 Rev. 5

Table 8-1. SHMS Data System Reliability. (3 sheets)

\begin{tabular}{|c|c|c|c|}
\hline Tank System & Days Available* & Days Unavailable & Percent Available \\
\hline AN-105 SHMS-B & 366 & 0 & 100.0 \\
\hline $\mathrm{GCS} 1 / \mathrm{GC}-1$ & 355 & 11 & 97.0 \\
\hline $\mathrm{GCS} 1 / \mathrm{GC}-2$ & 343 & 23 & 93.7 \\
\hline FTIR & 337 & 29 & 92.1 \\
\hline AN-107 SHMS-B & 212 & 154 & 57.9 \\
\hline AN Stck SHMS-D & 363 & 3 & 99.2 \\
\hline AW-101 SHMS-B & 359 & 7 & 98.1 \\
\hline GCS2/ GC-1 & 327 & 39 & 89.3 \\
\hline $\mathrm{GCS} 2 / \mathrm{GC}-2$ & 338 & 28 & 92.3 \\
\hline GCS2 / FTIR & 354 & 12 & 96.7 \\
\hline AW Stck SHMS-D & 229 & 0 & 100.0 \\
\hline AX-101 SHMS-B & 365 & 1 & 99.7 \\
\hline AX-103 SHMS-B & 0 & 229 & 0.0 \\
\hline AY-102 SHMS-C & 349 & 17 & 95.4 \\
\hline $\mathrm{GC}$ & 322 & 44 & 88.0 \\
\hline AZ-101 SHMS-E & 274 & 92 & 74.9 \\
\hline AZ-102 SHMS-E & 207 & 21 & 90.8 \\
\hline BY-103 SHMS-B & 366 & 0 & 100.0 \\
\hline BY-105 SHMS-E+ & 366 & 0 & 100.0 \\
\hline $\mathrm{GC}$ & 346 & 20 & 94.5 \\
\hline PHOTO & 213 & 153 & 58.2 \\
\hline BY-106 SHMS-B & 366 & 0 & 100.0 \\
\hline BY-109 SHMS-B & 229 & 0 & 100.0 \\
\hline C-106 SHMS-C & 319 & 47 & 87.2 \\
\hline $\mathrm{GC}$ & 284 & 82 & 77.6 \\
\hline S-101 SHMS-E & 177 & 52 & 77.3 \\
\hline S-102 SHMS-B & 280 & 86 & 76.5 \\
\hline S-106 SHMS-E+ & 358 & 8 & 97.8 \\
\hline $\mathrm{GC}$ & 335 & 31 & 91.5 \\
\hline PHOTO & 243 & 123 & 66.4 \\
\hline S-107 SHMS-B & 150 & 79 & 65.5 \\
\hline
\end{tabular}


Table 8-1. SHMS Data System Reliability. (3 sheets)

\begin{tabular}{|c|c|c|c|}
\hline Tank System & Days Available* & Days Unavailable & Percent Available \\
\hline S-109 SHMS-E+ & 229 & 0 & 100.0 \\
\hline $\mathrm{GC}$ & 215 & 14 & 94.3 \\
\hline PHOTO & 139 & 90 & 60.7 \\
\hline S-111 SHMS-B & 229 & 0 & 100.0 \\
\hline S-112 SHMS-B & 229 & 0 & 100.0 \\
\hline SX-101 SHMS-B & 175 & 191 & 47.8 \\
\hline SX-102 SHMS-B & 139 & 90 & 60.7 \\
\hline SX-103 SHMS-E+ & 366 & 0 & 100.0 \\
\hline GC & 341 & 25 & 93.2 \\
\hline PHOTO & 169 & 197 & 46.2 \\
\hline SX-104 SHMS-B & 332 & 12 & 96.5 \\
\hline SX-105 SHMS-B & 366 & 0 & 100.0 \\
\hline SX-106 SHMS-B & 342 & 0 & 100.0 \\
\hline SX-109 SHMS-B & 229 & 0 & 100.0 \\
\hline SY-101 SHMS & 360 & 6 & 98.4 \\
\hline SY241 SHMS & 362 & 4 & 98.9 \\
\hline SY01A-SHMS & 354 & 12 & 96.7 \\
\hline SY-102 SHMS-E+ & 340 & $26^{\circ}$ & 92.9 \\
\hline $\mathrm{GC}$ & 330 & 36 & 90.2 \\
\hline PHOTO & 277 & 89 & 75.7 \\
\hline SY-103 SHMS-B & 352 & 14 & 96.2 \\
\hline T-110 SHMS-B & 227 & 2 & 99.1 \\
\hline U-102 SHMS-B & 326 & 40 & 89.1 \\
\hline U-103 SHMS-B & 365 & 1 & 99.7 \\
\hline U-105 SHMS-E+ & 344 & 22 & 94.0 \\
\hline GC & 331 & 35 & 90.4 \\
\hline PHOTO & 280 & 86 & 76.5 \\
\hline U-107 SHMS-B & 366 & 0 & 100.0 \\
\hline U-108 SHMS-B & 282 & 84 & 77.0 \\
\hline U-109 SHMS-B & 366 & 0 & 100.0 \\
\hline
\end{tabular}

*Because of isolation of several SHMS cabinets this year, not all units were available for 366 days (see Table 4-1). 
Table 8-2. Summary of SHMS Data System Reliability

\begin{tabular}{|l|c|c|c|}
\hline \multicolumn{1}{|c|}{ Tank System } & Days Available & Days Unavailable & Percent Available \\
\hline PHOTO & 1,610 & 1,181 & 57.7 \\
\hline GC & 3,476 & 412 & 89.4 \\
\hline GCS & 1,363 & 101 & 93.1 \\
\hline FTIR & 691 & 41 & 94.4 \\
\hline Whittaker ${ }^{\text {TM }}$ Cells & 13,782 & 1,592 & 89.6 \\
\hline
\end{tabular}

\subsection{CURRENT SYSTEM ISSUES AND CORRECTIVE ACTIONS}

Several issues affecting the operations of the SHMS units and the quality of the data obtained have been encountered during the years of operation. The major issues include plugging of the sample line filter with condensed water, failure of the system to record data, and plugging of the sample line with ammonium nitrate. The efficiency of operations during the time period July I, 1999, through June 30,2000, has been generally excellent, but a few issues required resolution this year.

\subsubsection{Description of System Issues}

Plugging of Sample Line Filter with Condensed Water - The waste tank headspace temperature is typically warmer than the ambient temperature. Because one of the major components of the waste is water, the moisture content in the headspace is expected to be above the saturation level for the ambient conditions. The SHMS design includes provisions to minimize the effects of moisture by heat tracing the sample lines and controlling the temperature of the instrumentation cabinet. This is intended to prevent moisture from condensing in the sample piping. Moisture becomes an issue in the system when the volume of collected water becomes so great that the sample line filter becomes plugged. Last year, this issue accounted for 36 percent of the down time. This year the issue became critical only in the SHMS operations on tank 241-SY-102. This tank has received significant new waste from tank 241-SY-101 and the U farm salt-well pumped tanks. How this change in tank chemistry led to increased moisture in the sample lines, resulting in filling the condensate bowl and subsequent shutdown of the SHMS is still uncertain.

Plugging of Sample Lines with Ammonium Nitrate - This problem has been encountered only with the system installed on tank 241-AX-103. The loss of this one SHMS unit accounts for 23 percent of the lost data days this year. In this case the sample line does not plug with water but with a substance composed of ammonium nitrate contaminated with plutonium-uranium extraction solvent and solvent degradation products. This material is known to have plugged Hanford Site waste tank ventilation systems on other occasions (Borsheim and Kirch 1991). 
Proper precautions must be taken when working on the portions of the system that may contain this material. The SHMS cabinet on this tank has been removed from service.

Extended "Down Time" for Photoacoustic Ammonia Monitors - Table 8-2 clearly shows that the Bruel and Kjaer ammonia monitors are not providing data in an efficient manner. Physical failure of the measurement systems occurs in four major areas: chopper belt failure, carousel belt failure, infrared source filament burnout, and sample pump failure. This instrument requires offsite vendor repair for all but the chopper belt replacement. In previous years, the vendor repair shop was located in Prosser, Washington - a fairly easily accessible site. This year, the nearest shop for this instrument service is in California. Service procurement, shipping, receiving inspection, and other issues associated with offsite support have contributed to the significant delays in system operation.

\subsubsection{Issue Resolution}

Plugging of Sample Line Filters with Condensed Water - For SHMS on tanks with a history or potential of high headspace moisture, gas sample conditioners have been installed. These systems consist of a condenser coil and a chilled annulus that separates moisture from the sample stream. These systems are intended to prevent moisture from clogging the SHMS sample lines and filters. These systems have been installed on tanks 241-A-101, 241-AX-101, 241-AY-102, 241-C-106, 241-S-102, 241-SX-102. A similar system is being requested for tank 241-SY-102.

Extended "Down Time" for Photoacoustic Ammonia Monitors - Replacement parts for the chopper belt have been kept available, and maintenance notification systems have been expedited, but the transportation and specialized shop issues are still unresolved. 
HNF-SD-WM-TI-797 Rev. 5

This page intentionally left blank. 


\subsection{CONCLUSIONS}

SHMS units were designed, procured, fabricated, and installed on all 25 FGWL tanks.

Additional SHMS units were installed on high priority tanks. The headspaces of the tanks have been observed for long enough to demonstrate that steady-state release of gas into the tank headspace of passively and actively ventilated tanks does not result in gas concentrations exceeding the action level. As a result, SHMS units were removed from eight tanks and placed in a standby mode on seven other tanks. The standby mode allows a SHMS cabinet to be available for future gas monitoring during transfer/pumping activities without having to maintain high maintenance and engineering costs until that activity occurs.

Monitoring to date has shown the following:

1. SSTs do not appear to be subject to large, rapid gas releases. The peak hydrogen concentrations during GREs in the SSTs have been below 25 percent of the LFL. GREs in the SSTs require days to increase from steady-state concentrations to peak concentrations. Interim stabilization activities and other waste-disturbing activities like mixer pump tests and transfers appear to have an effect on the steady-state hydrogen concentration of most tanks monitored during the last year.

2. SHMS reliably detect GREs. Redundant systems (e.g., GCS) have been placed on the systems that generate the most flammable gases; these systems have verified Whittaker ${ }^{\mathrm{TM}}$ Cell data.

3. Grab samples taken in the pump pit area immediately above the tanks demonstrate that the SHMS samplers in the dome space can accurately measure pump pit flammable gas concentrations. 
HNF-SD-WM-TI-797 Rev. 5

This page intentionally left blank. 


\subsection{REFERENCES}

Babad, H., G. D. Johnson, J. A. Lechelt, and D. A. Reynolds, 1992, Evaluation of the Generation and Release of Flammable Gases in Tank 241-SY-101, WHC-EP-0517, Rev. 0, Westinghouse Hanford Company, Richland, Washington.

Borsheim, G. L., and N. W. Kirch, 1991 (Supplemented May 1992 and January 1993), Summary of Single Shell Tank Waste Stability, WHC-EP-0347, Rev. 0, Westinghouse Hanford Company, Richland, Washington.

Conner, J. M., and G. M. Koreski, 1999, Quarterly Review of 241-SY-101 Mixer Pump Data: July - September, 1999, HNF-5265, Rev. 0, Lockheed Martin Hanford Corp., Richland, Washington.

Conner, J. M., and G. M. Koreski, 2000a, Quarterly Review of 241-SY-101 Mixer Pump Data: October-December, 1999, RPP-5869, Rev. 0, CH2M HILL Hanford Group, Inc., Richland, Washington.

Conner, J. M., and G. M. Koreski, 2000b, Quarterly Review of 24I-SY-10I Mixer Pump Data: January - March, 2000, RPP-6332-4511, Rev. 0, CH2M HILL Hanford Group, Inc., Richland, Washington.

DOE, 2000, Contract No. DE-AC06-99RL14047-Implementation of Field Optimizations Performance Incentive ORP 3.2.3 (letter 00-TSD-001 from J. D. Voice to M. P. DeLozier, CH2M HILL Hanford Group, Inc., dated January 6, 2000), U.S. Department of Energy, Richland Operations Office, Richland, Washington.

DOE Order 5480.4, 1984, Environmental Protection, Safety, and Health Protection Standards, U.S. Department of Energy, Washington, D.C.

Ecology, EPA, and DOE, 1994, Hanford Federal Facility Agreement and Consent Order, as amended, Washington State Department of Ecology, U.S. Environmental Protection Agency, and U.S. Department of Energy, Olympia, Washington.

Estey, S. D., 1998, Flammable Gas Tank Safety Program: Technical Basis for Gas Sampling and Monitoring, HNF-SD-WM-ES-346, Rev. 1, Lockheed Martin Hanford Corporation, Richland, Washington.

Harmon, H. D., 1991a, Safety Measures for Waste Tanks at the Hanford Site, Richland, Washington, (letter 9059124 to R. E. Gerton, U.S. Department of Energy, Richland Operations Office, January 8, 1991), Westinghouse Hanford Company, Richland, Washington.

Harmon, H. D., 1991b, Watch List for Tanks Which May Have Hydrogen Buildup, (letter 9001478B RI to R. E. Gerton, U.S. Department of Energy, Richland Operations Office, February 8, 1991), Westinghouse Hanford Company, Richland, Washington. 
Hu, T. A., 2000, Empirical Rate Equation Model and Rate Calculations of Hydrogen Generation for Hanford Tank Waste, HNF-3851, Rev. 0A, CH2M HILL Hanford Group, Inc., Richland, Washington.

LHMC, 1999, Implementation of Field Optimizations - Performance Incentive ORP 3.2 .3 (letter LMHC-9958931 from M. P. Delozier to R. T. French, Office of River Protection, dated December 20, 1999), Lockheed Martin Hanford Corporation, Richland, Washington.

Mahoney, L.A., J. L. Huckaby, S. A. Bryan, and G. D. Johnson, 2000, Overview of the Flammability of Gases Generated in Hanford Waste Tanks, PNNL-13269, Rev. 0, Pacific Northwest National Laboratory, Richland, Washington.

McCain, D. J., 1999a, Results of Vapor Space Monitoring of Flammable Gas Watch List Tanks, HNF-SD-WM-TI-797, Rev. 4, Lockheed Martin Hanford Corporation, Richland, Washington.

McCain, D. J., 1999b, Engineering Task Plan for Standard Hydrogen Monitoring System Operation, HNF-SD-WM-ETP-227, Rev. 2, Lockheed Martin Hanford Corp., Richland, Washington.

McCain, D. J., 2000, An Analysis of Tank and Pump Pit Flammable Gas Data in Support of Saltwell Pumping Safety Basis Simplification, RPP-6334, Rev. 0-A, CH2M HILL Hanford Group, Inc., Richland, Washington.

Minteer, D. J., 1996, Waste Tank 241-AN-105 Gas Release Response Recommendation, WHC-SD-WM-ER-524, Rev. 0, Westinghouse Hanford Company, Richland, Washington.

NFPA 69, 1992, Explosion Prevention Systems, National Fire Protection Association, Quincy, Massachusetts.

Schneider, T. C., 1996, Standard-D Hydrogen Monitoring System, System Design Description, WHC-SD-WM-SDD-059, Rev. 0, Westinghouse Hanford Company, Richland, Washington.

Stewart, C. W., J. M. Alzheimer, and M. E. Brewster, 1996a, In Situ Rheology and Gas Volume In Hanford Double-Shell Waste Tanks, PNNL-11296, Pacific Northwest National Laboratory, Richland, Washington.

Stewart, C. W., M. E. Brewster, and P. A. Gauglitz, 1996b, Gas Retention and Release Behavior in Hanford Single-Shell Waste Tanks, PNNL-11391, Pacific Northwest National Laboratory, Richland, Washington.

Wilkins, N. E., 1993, Summary of Vapor Analysis from Flammable Gas Watch List Tanks, WHC-SD-WM-TI-548, Rev. 0, Westinghouse Hanford Company, Richland, Washington. 


\section{HNF-SD-WM-TI-797 Rev. 5}

Wyden Amendment, "Safety Measures for Waste Tanks at Hanford Nuclear Reservation,"

Section 3137 of the National Defense Authorization Act for Fiscal Year 1991, Public Law 101-510, November 5, 1990. 
HNF-SD-WM-TI-797 Rev. 5

This page intentionally left blank. 


\section{APPENDIX A \\ FLAMMABLE GAS CONCENTRATIONS FOR SHMS TANKS JULY 1999 THROUGH JUNE 2000}

Note: In those cases where two analytical systems measure the same analyte in the same tank, the most accurate system data are posted in this appendix. In some cases, the less accurate system is used to fill in the "data gap" created by down time on the more accurate system. 
HNF-SD-WM-TI-797 REV 5

This page intentionally left blank.

A-ii 
HNF-SD-WM-TI-797 REV 5

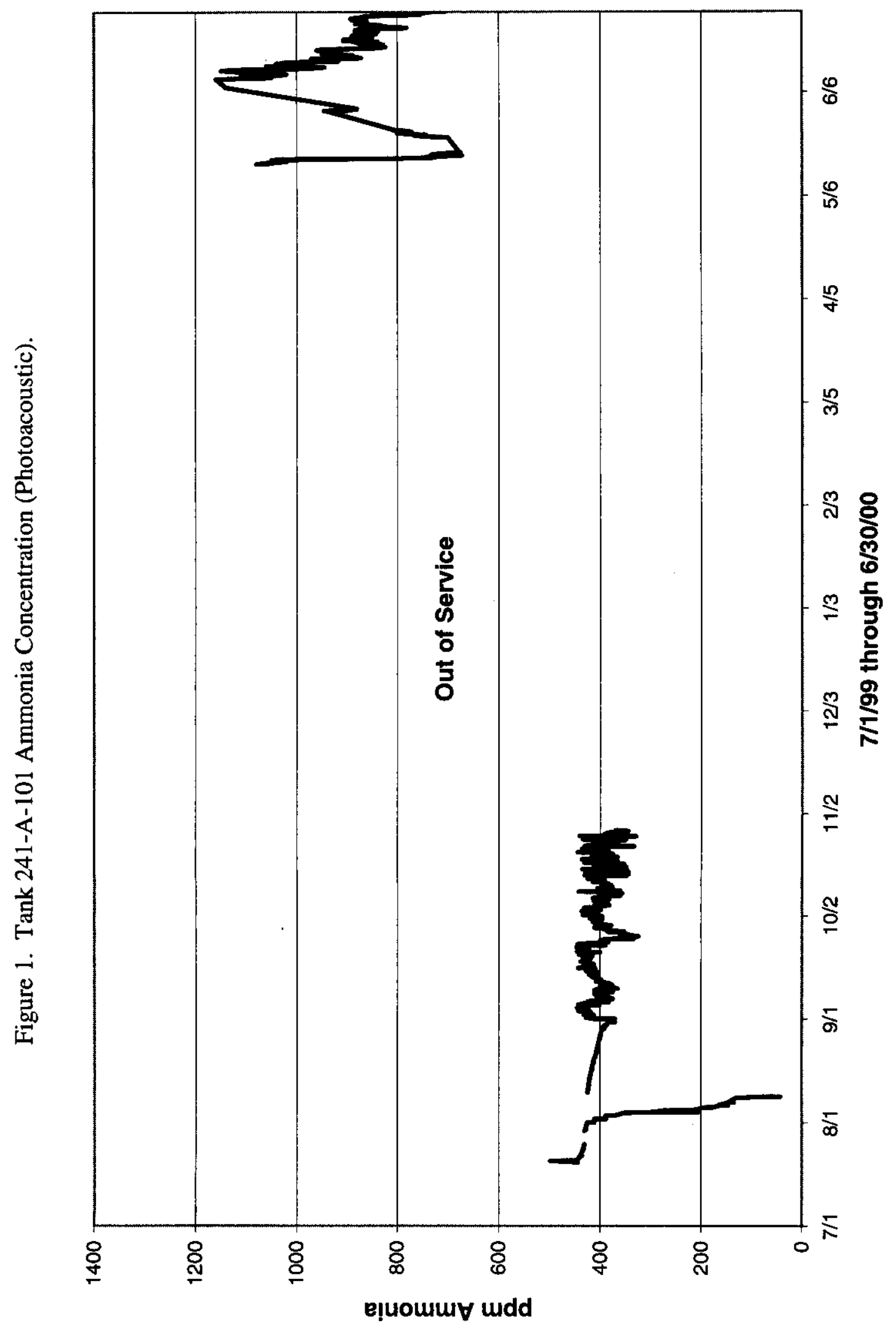

A-1 


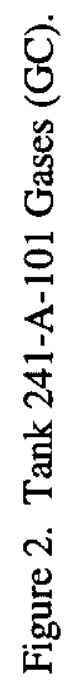

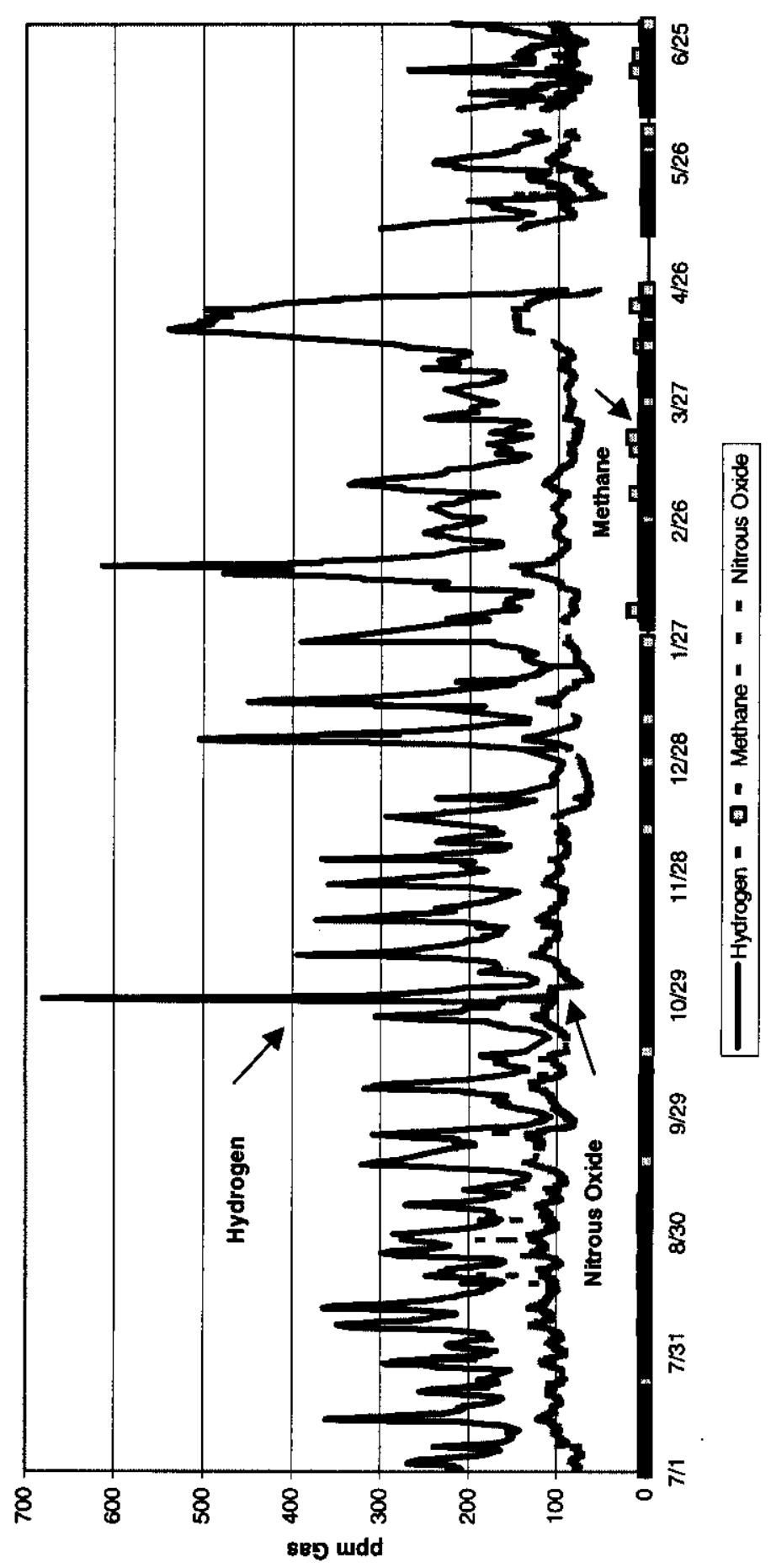


HNF-SD-WM-TI-797 REV 5

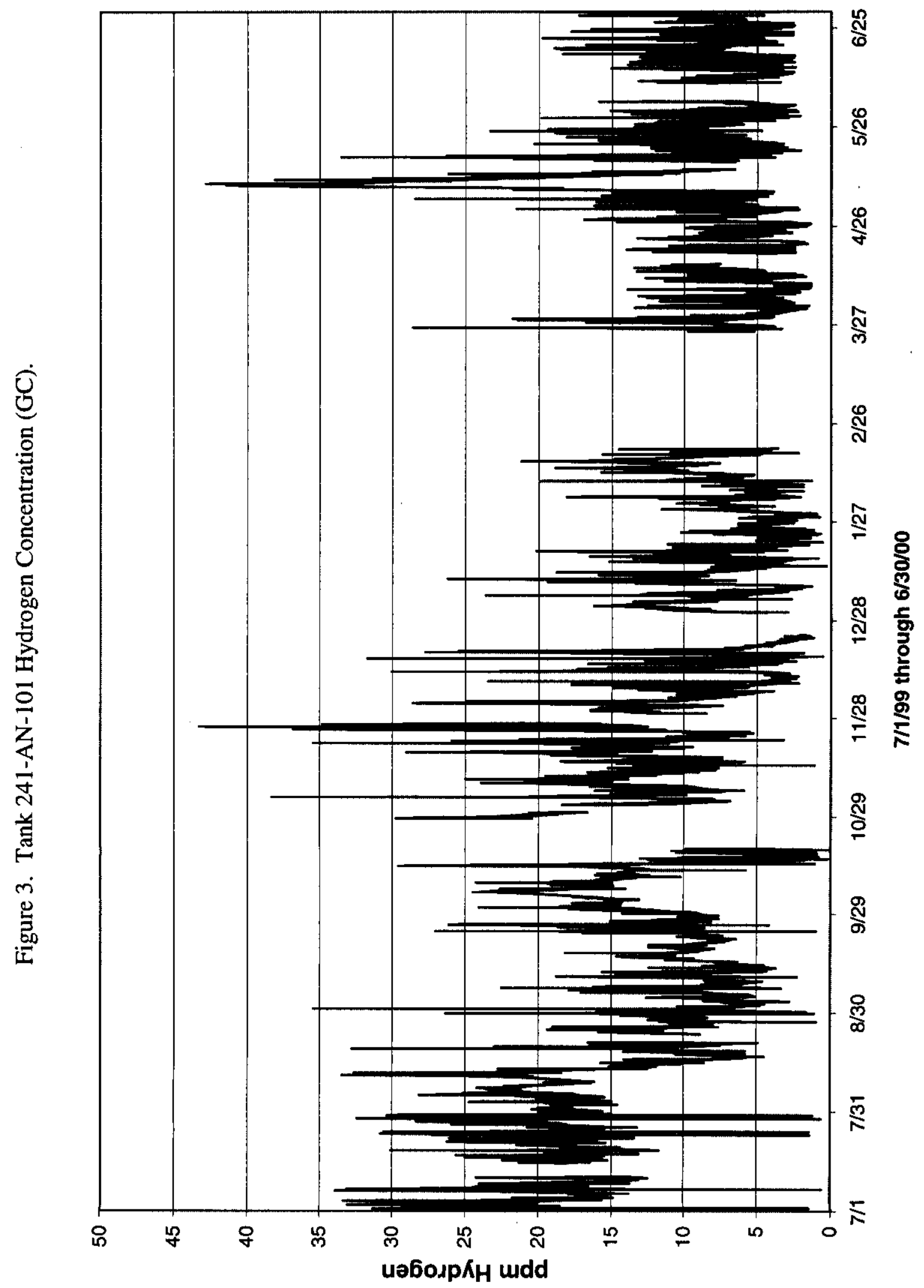


HNF-SD-WM-TI-797 REV 5

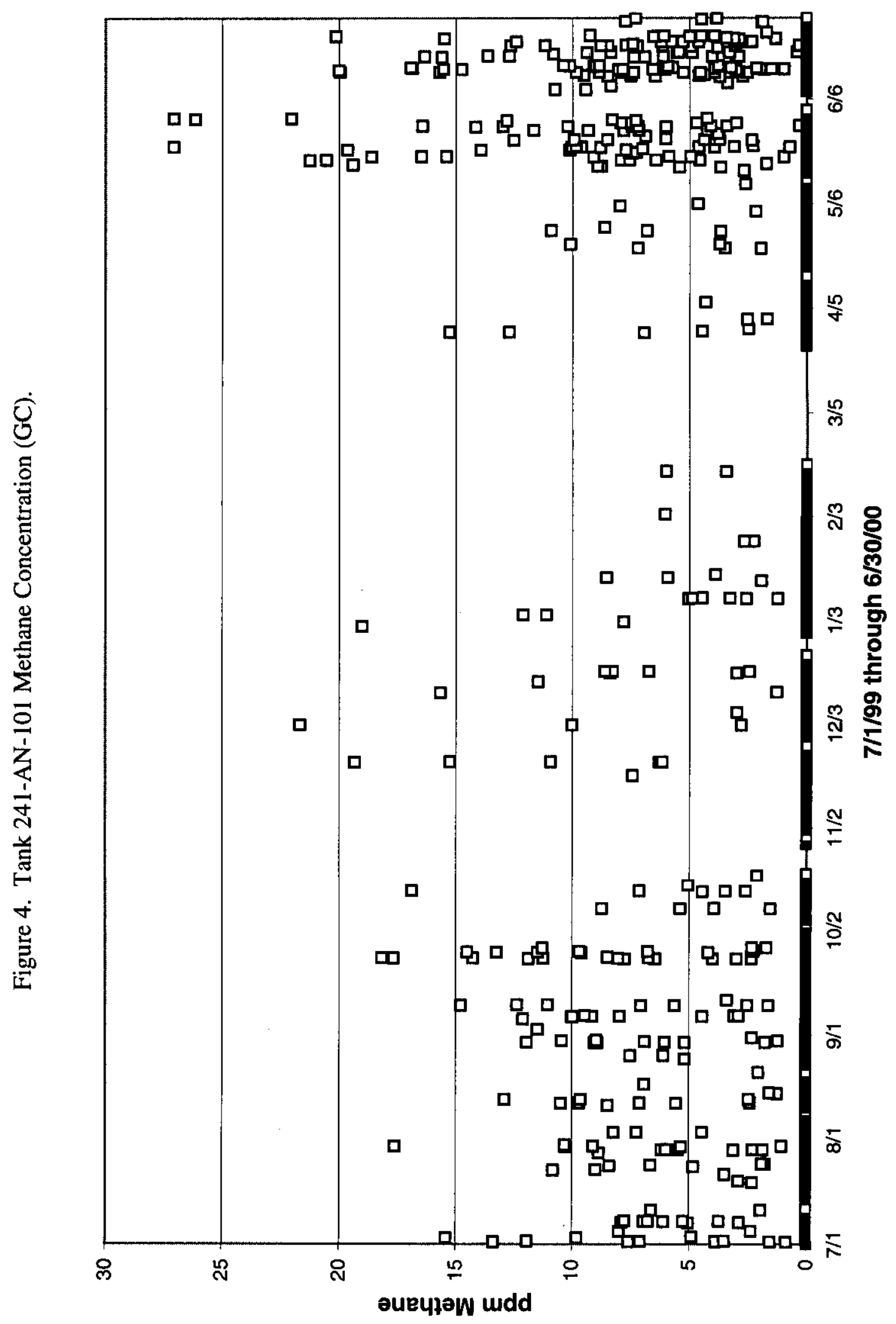




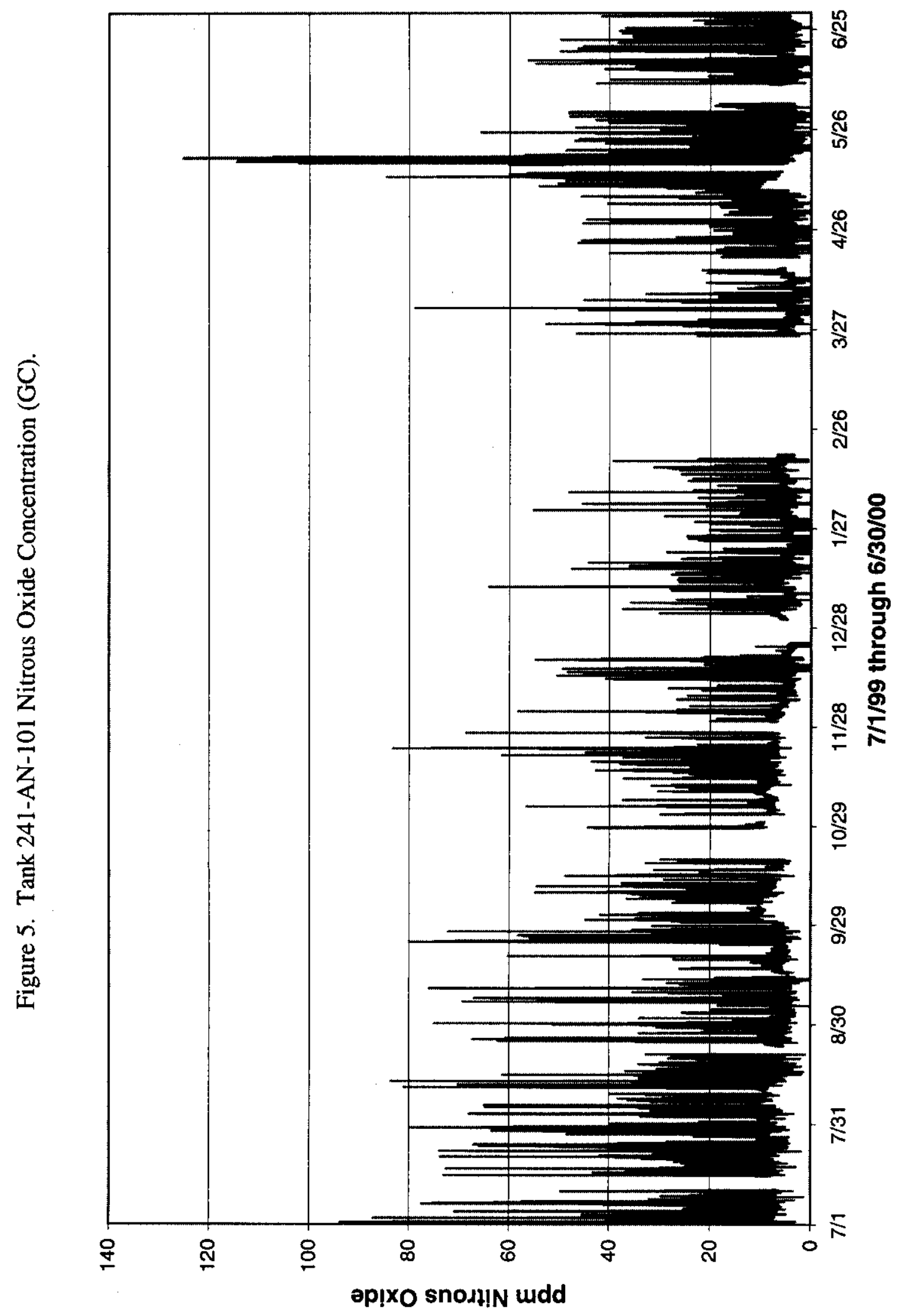




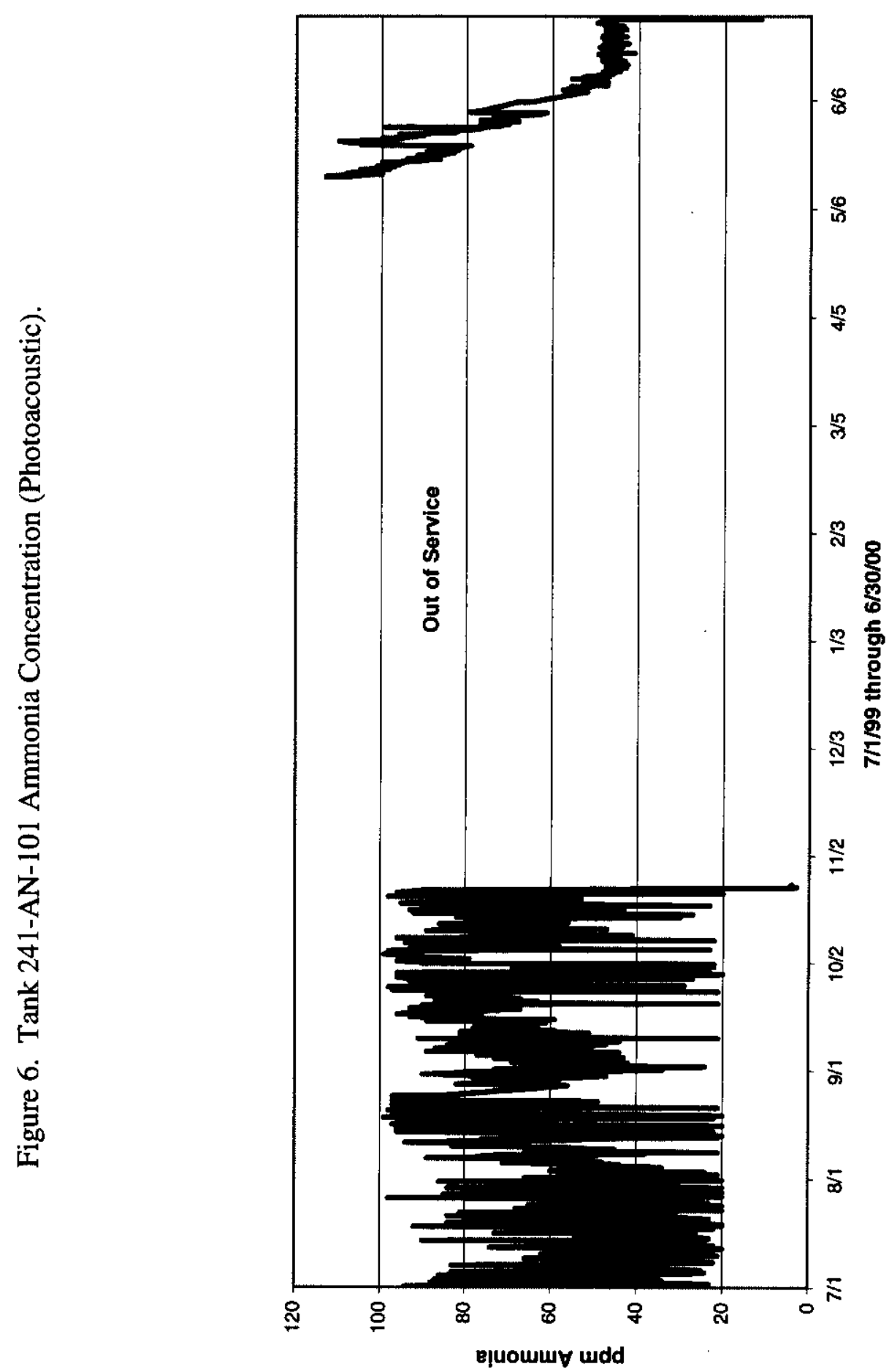


HNF-SD-WM-TI-797 REV 5

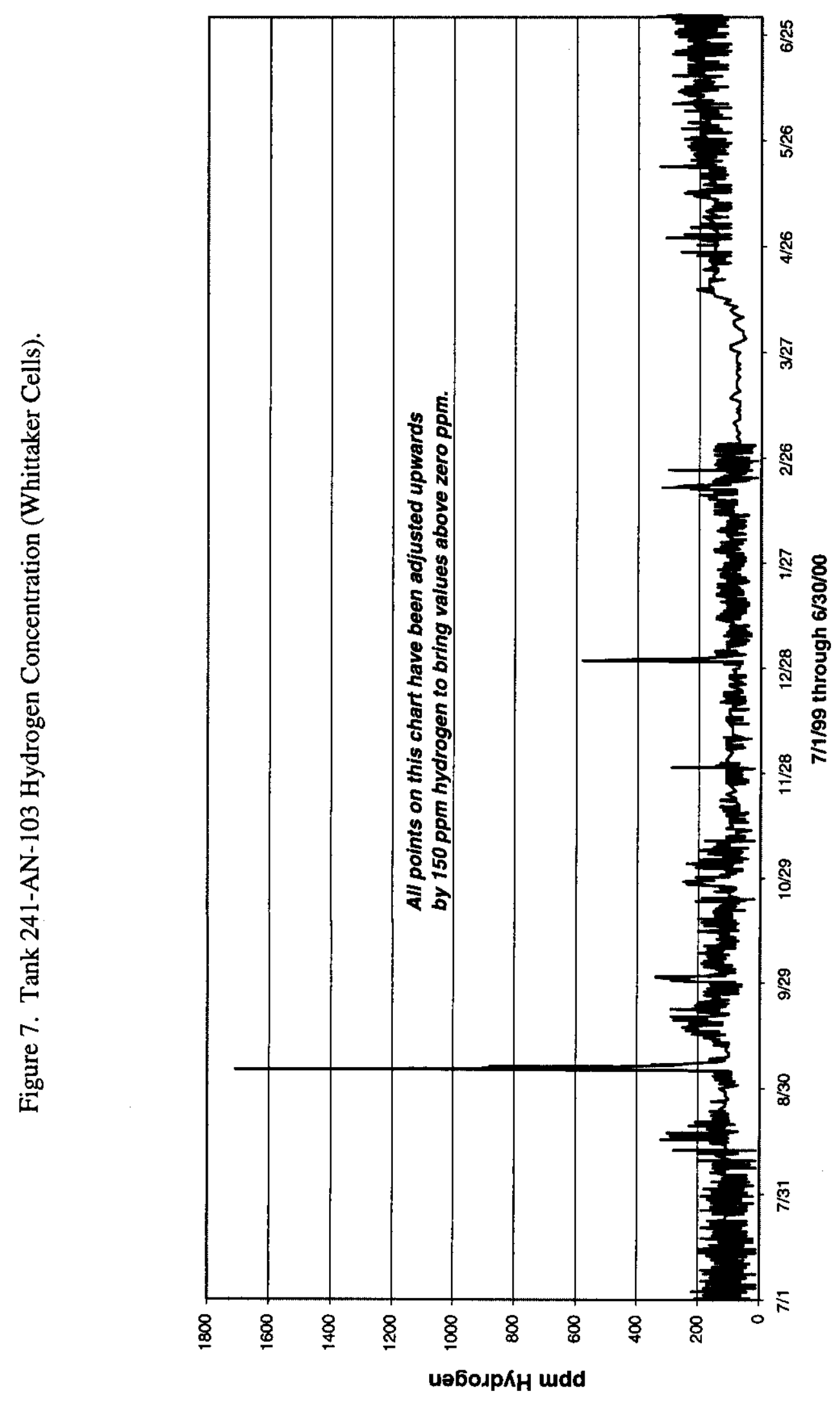

A-7 


\section{HNF-SD-WM-TI-797 REV 5}

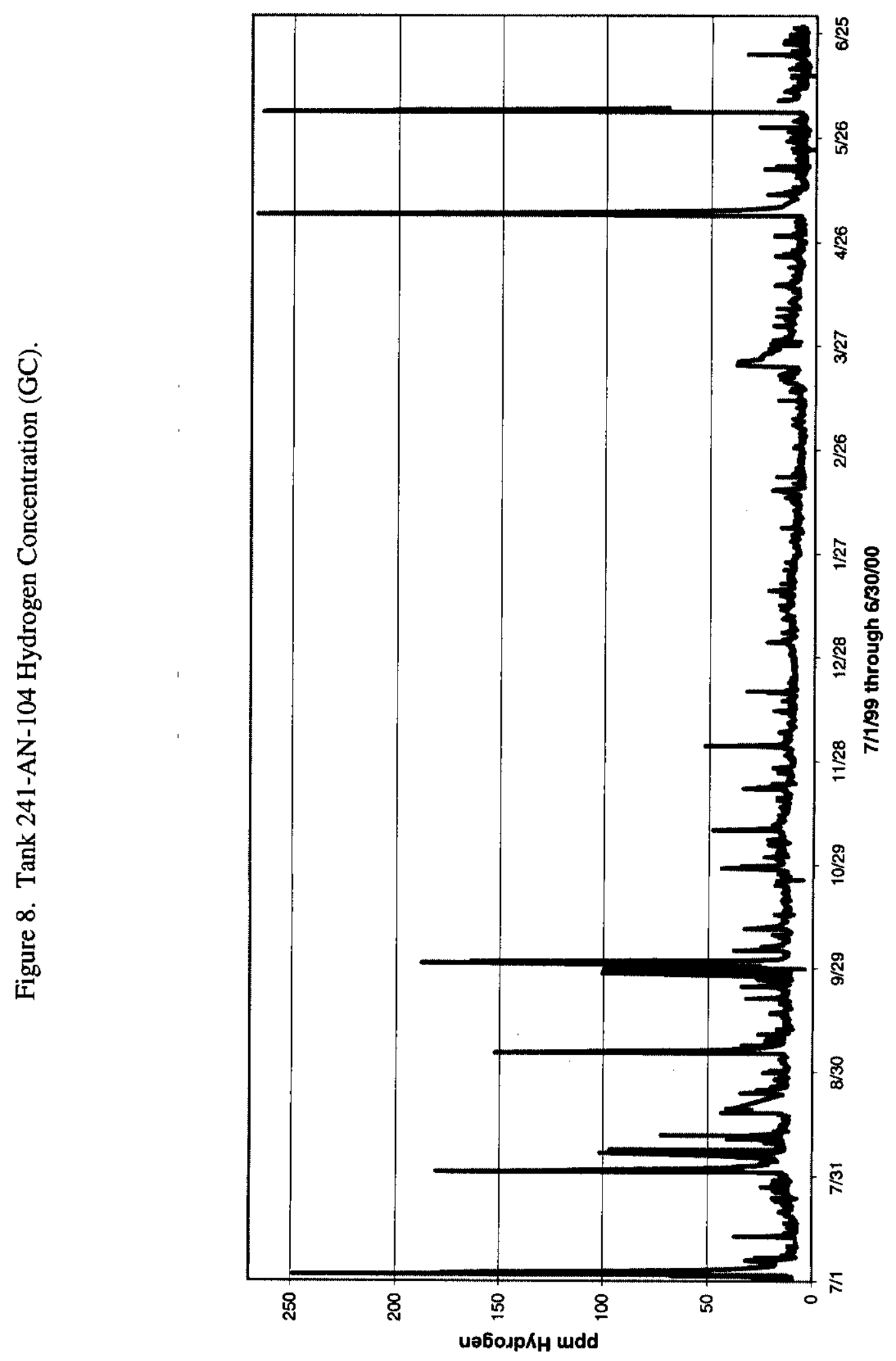




$$
1]
$$


HNF-SD-WM-TI-797 REV 5

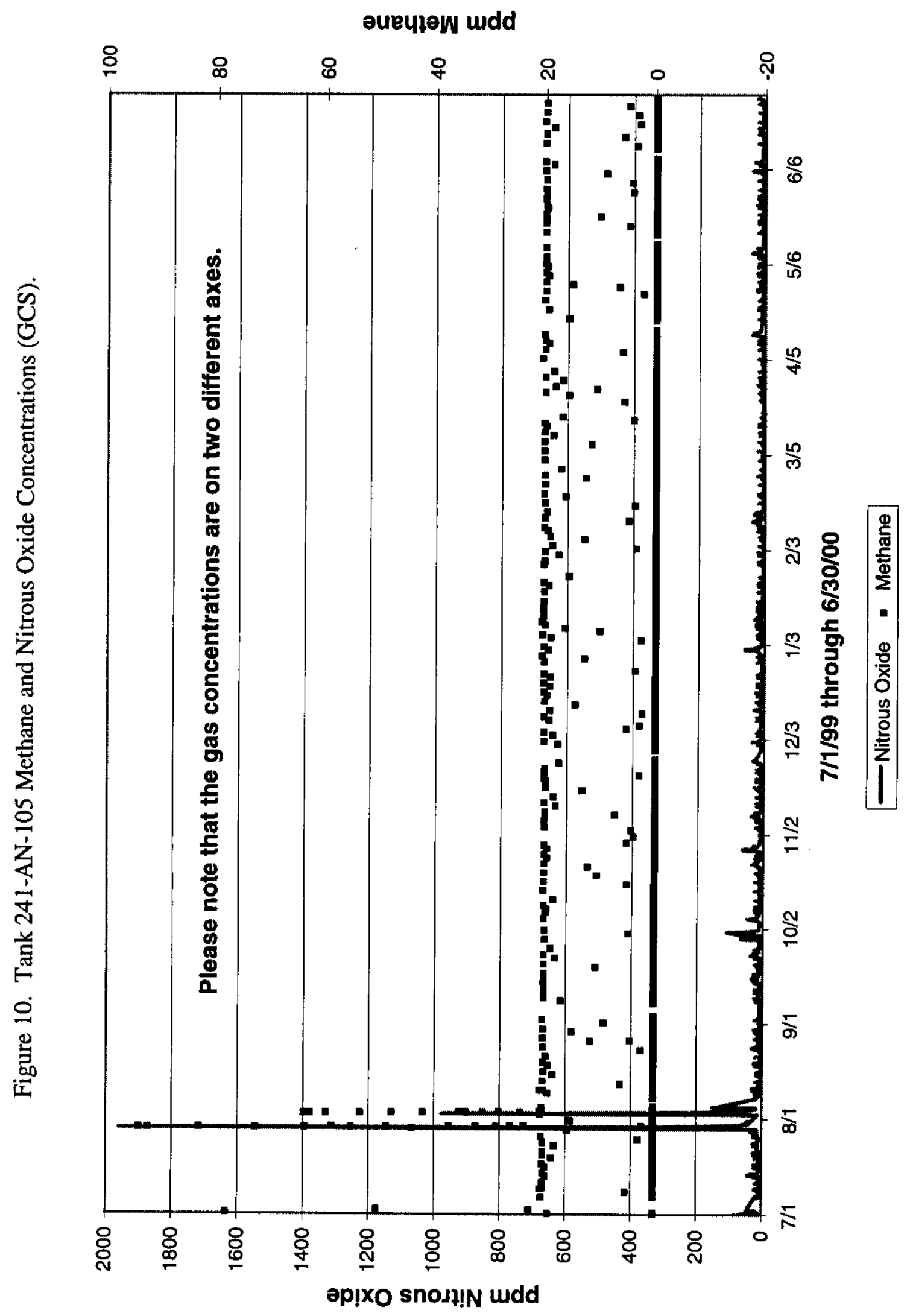


HNF-SD-WM-TI-797 REV 5

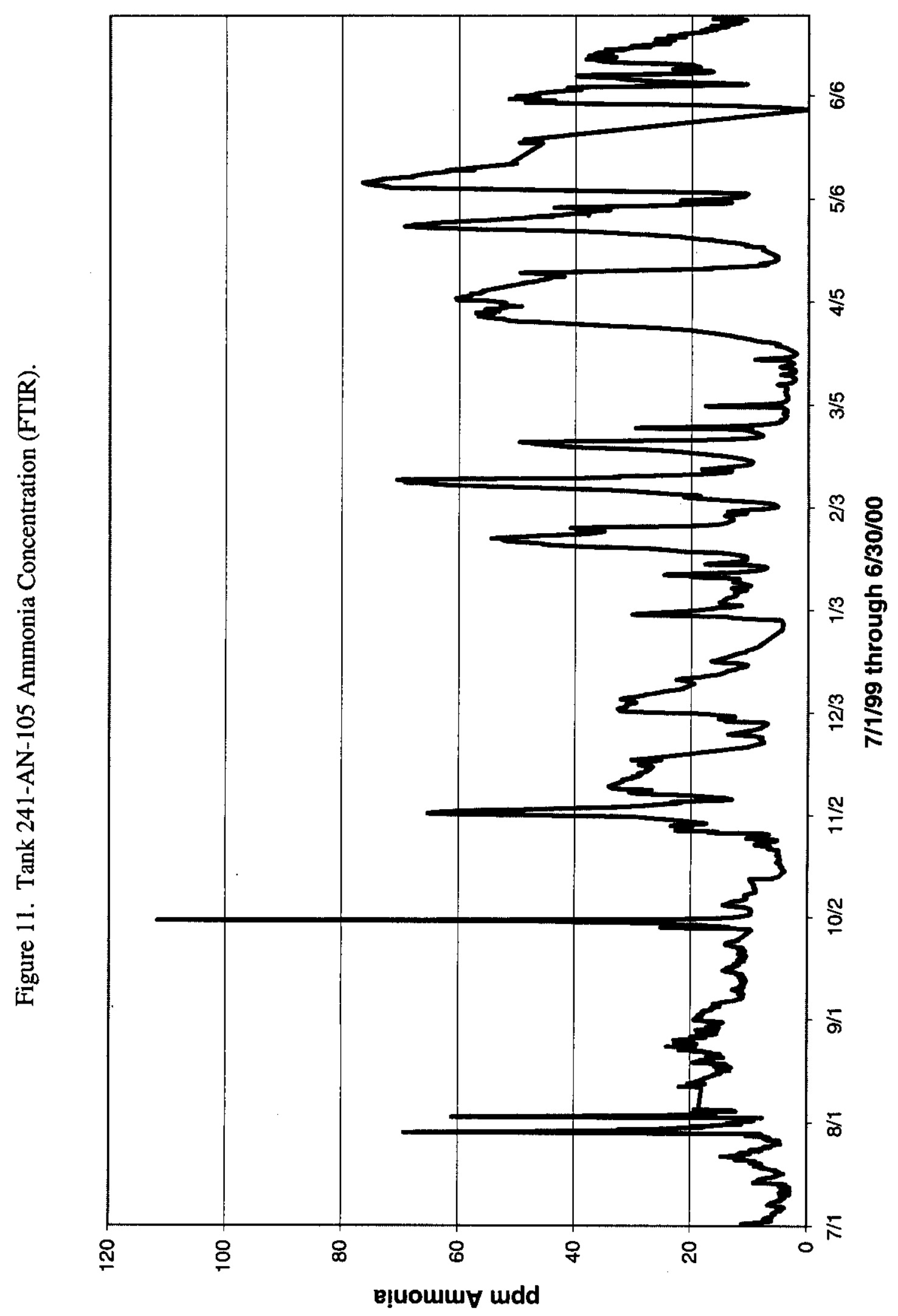




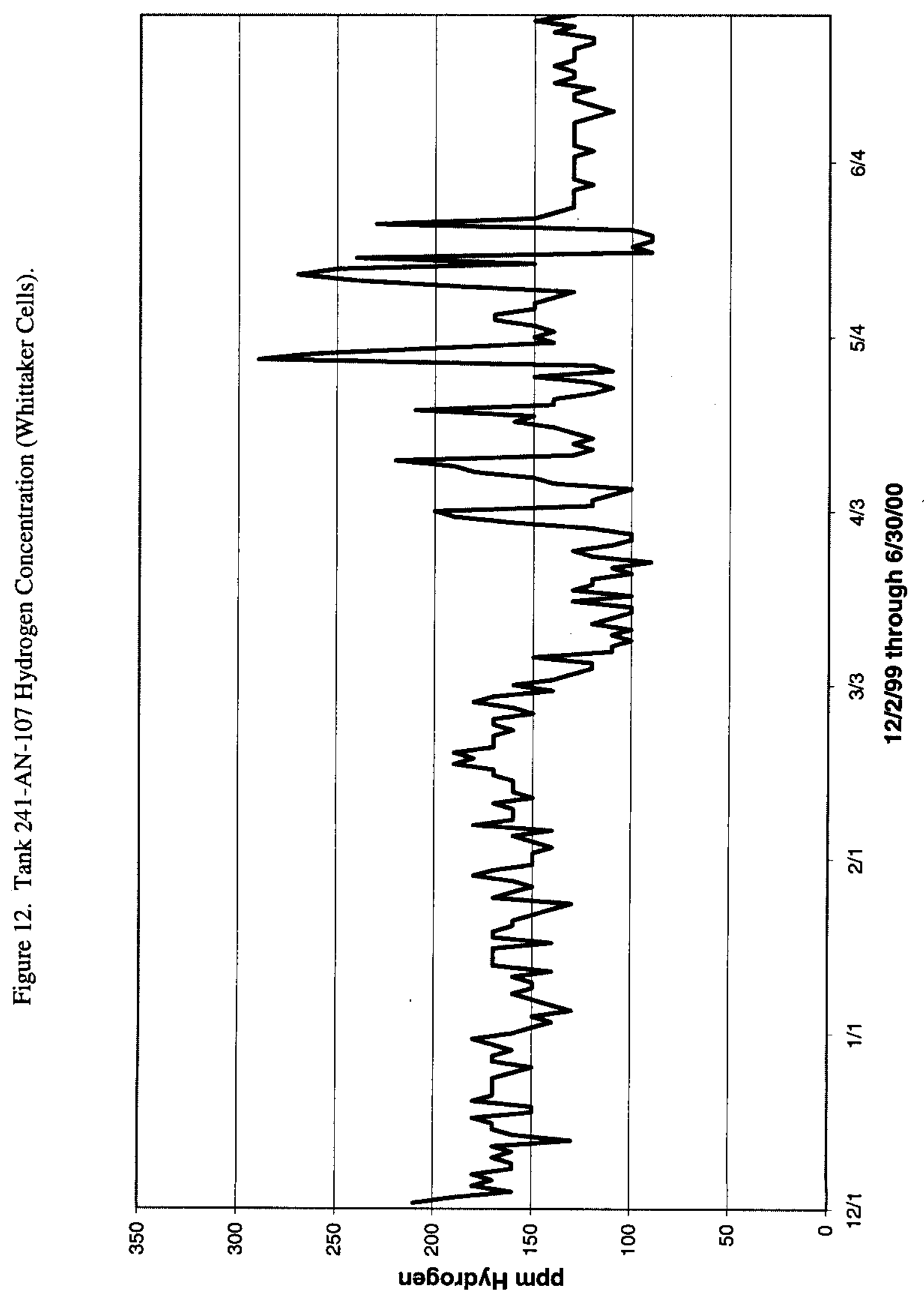

A-12 
HNF-SD-WM-TI-797 REV 5

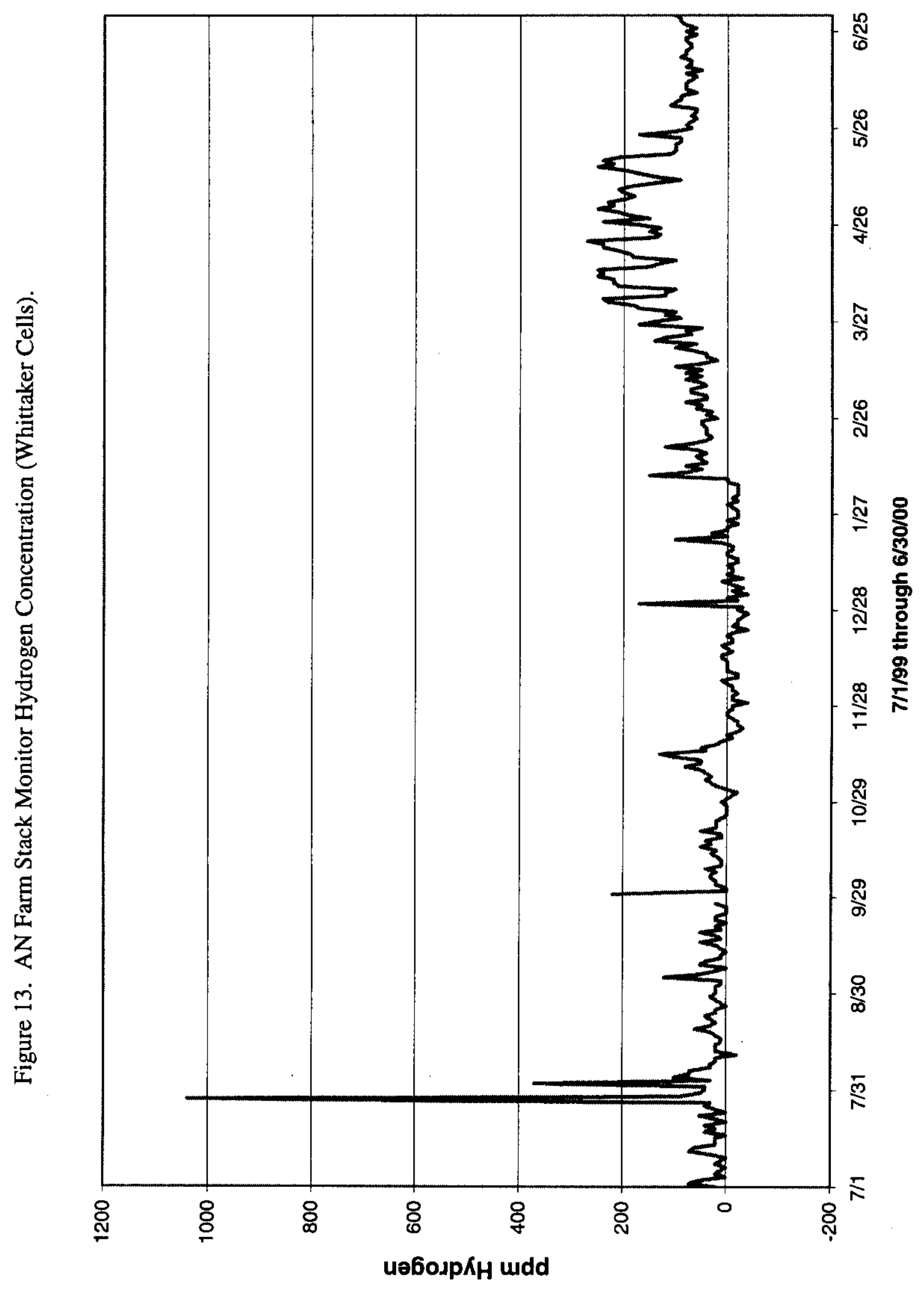


HNF-SD-WM-TI-797 REV 5

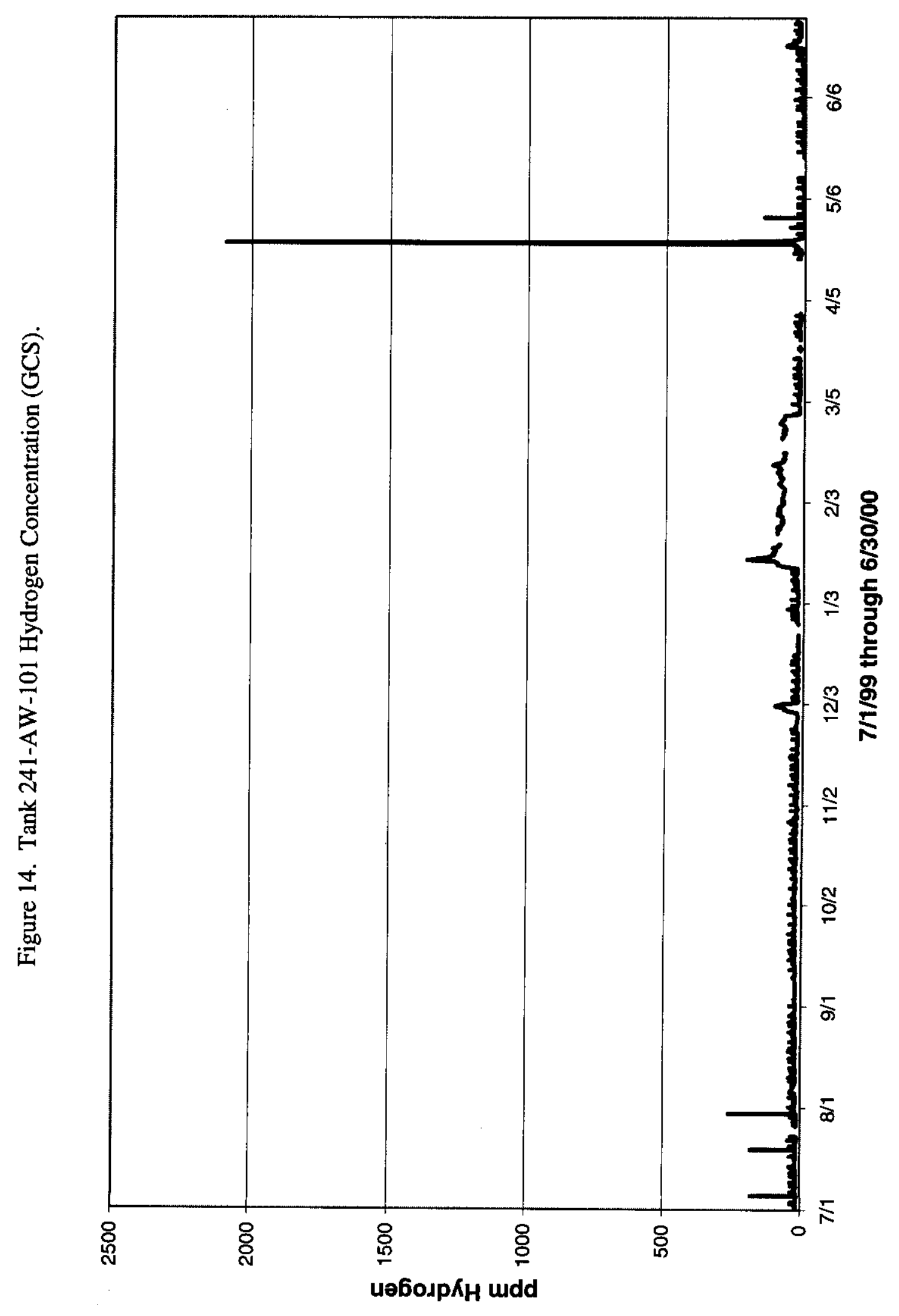

A-14 


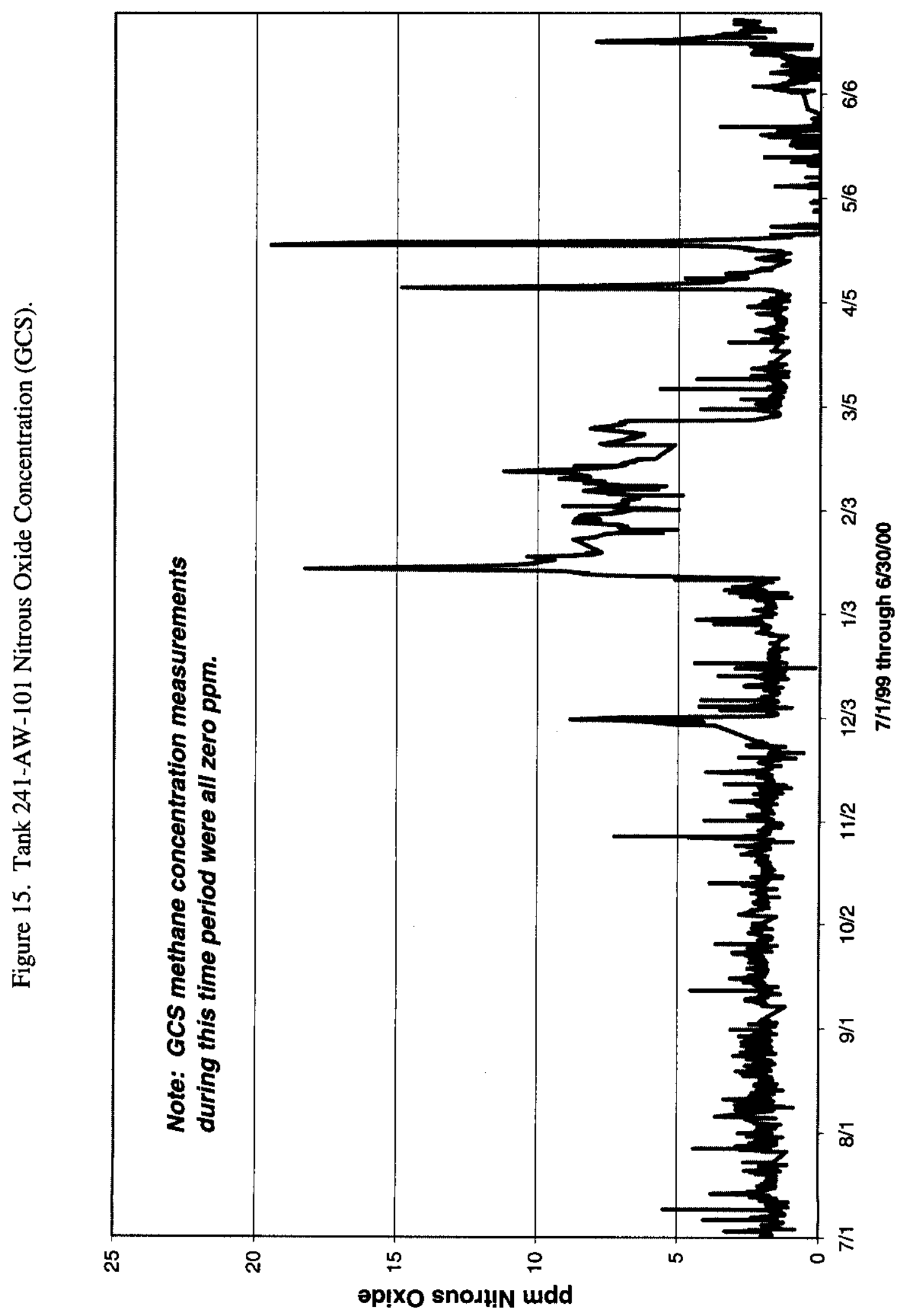




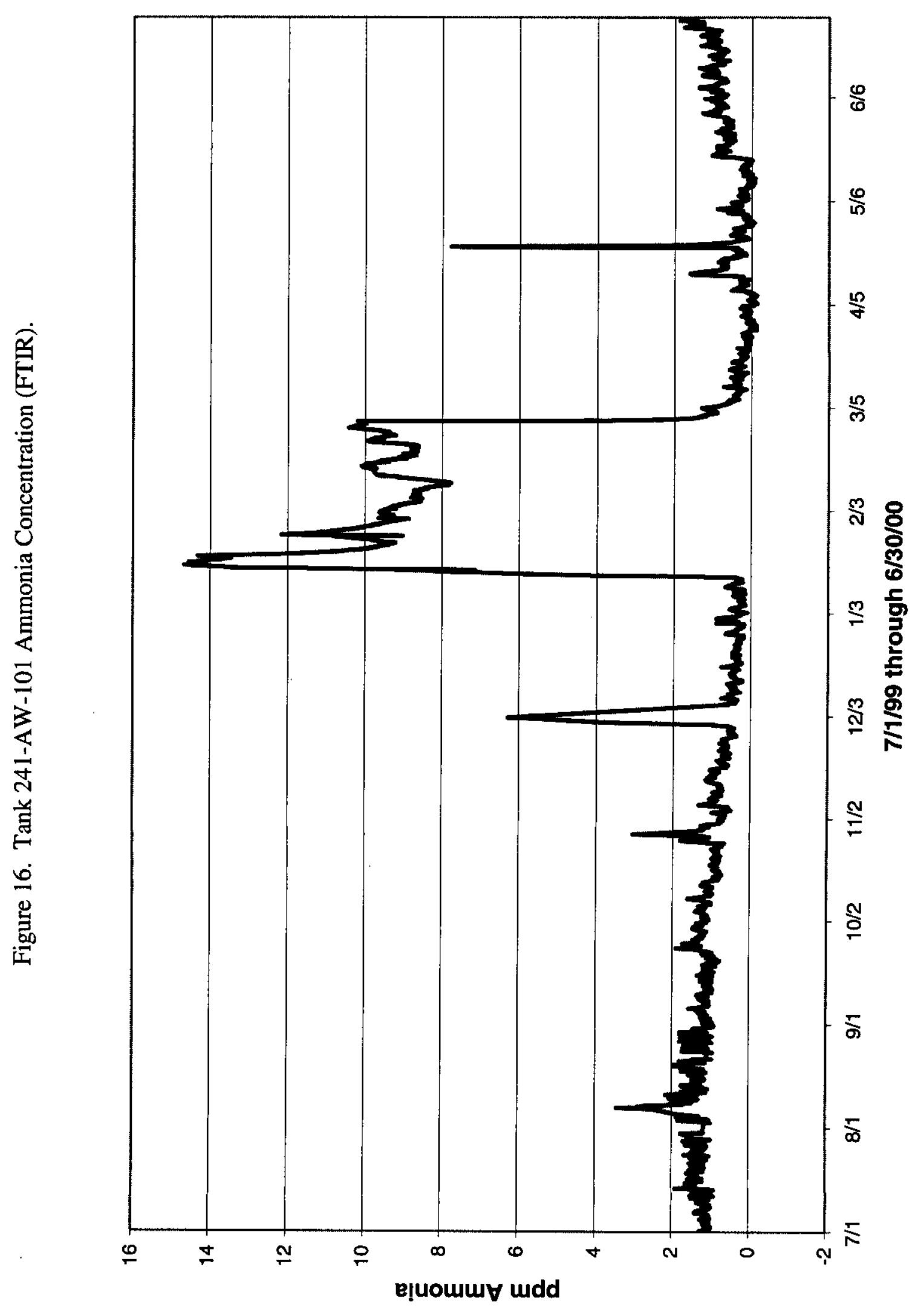


HNF-SD-WM-TI-797 REV 5

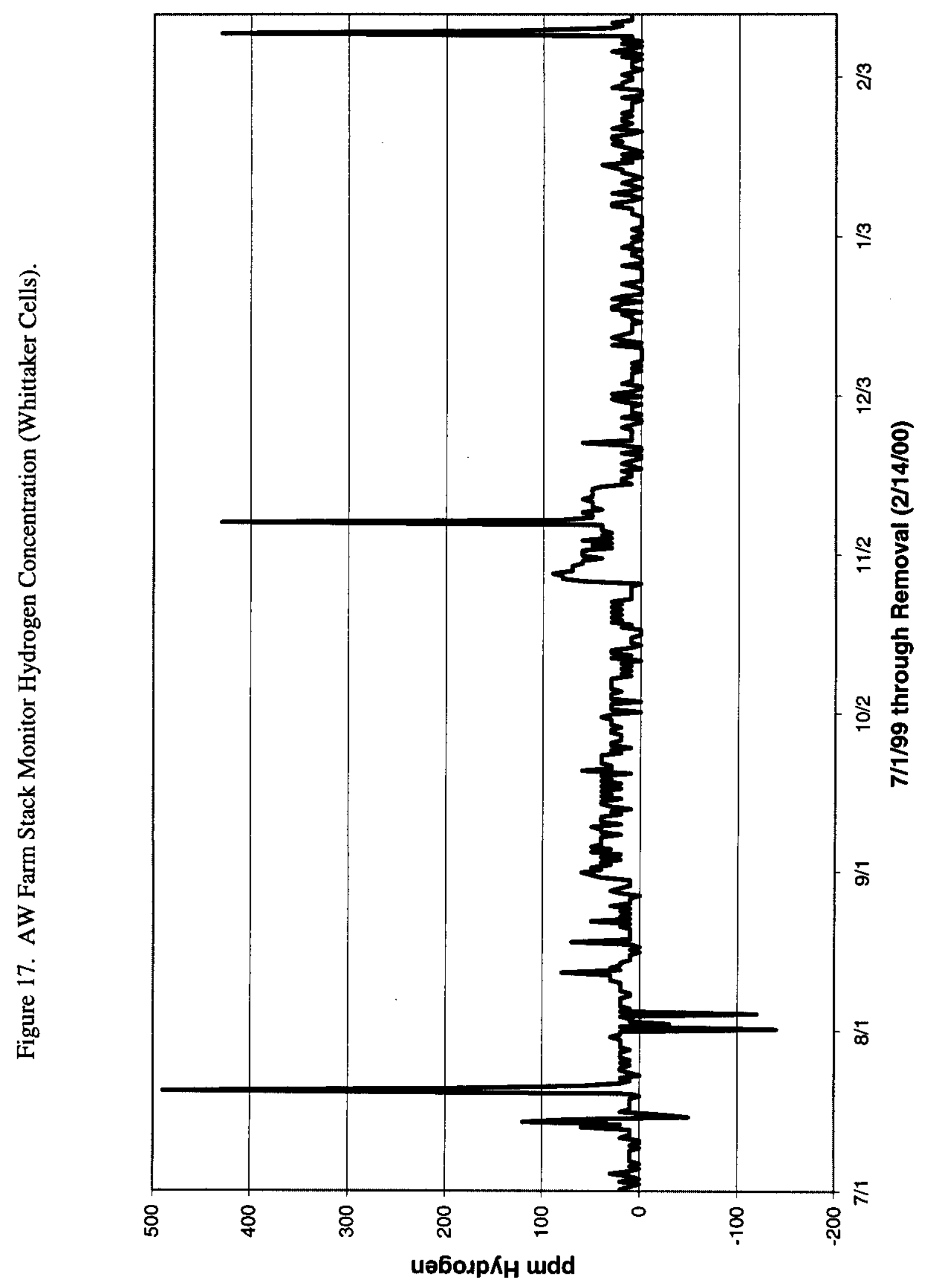




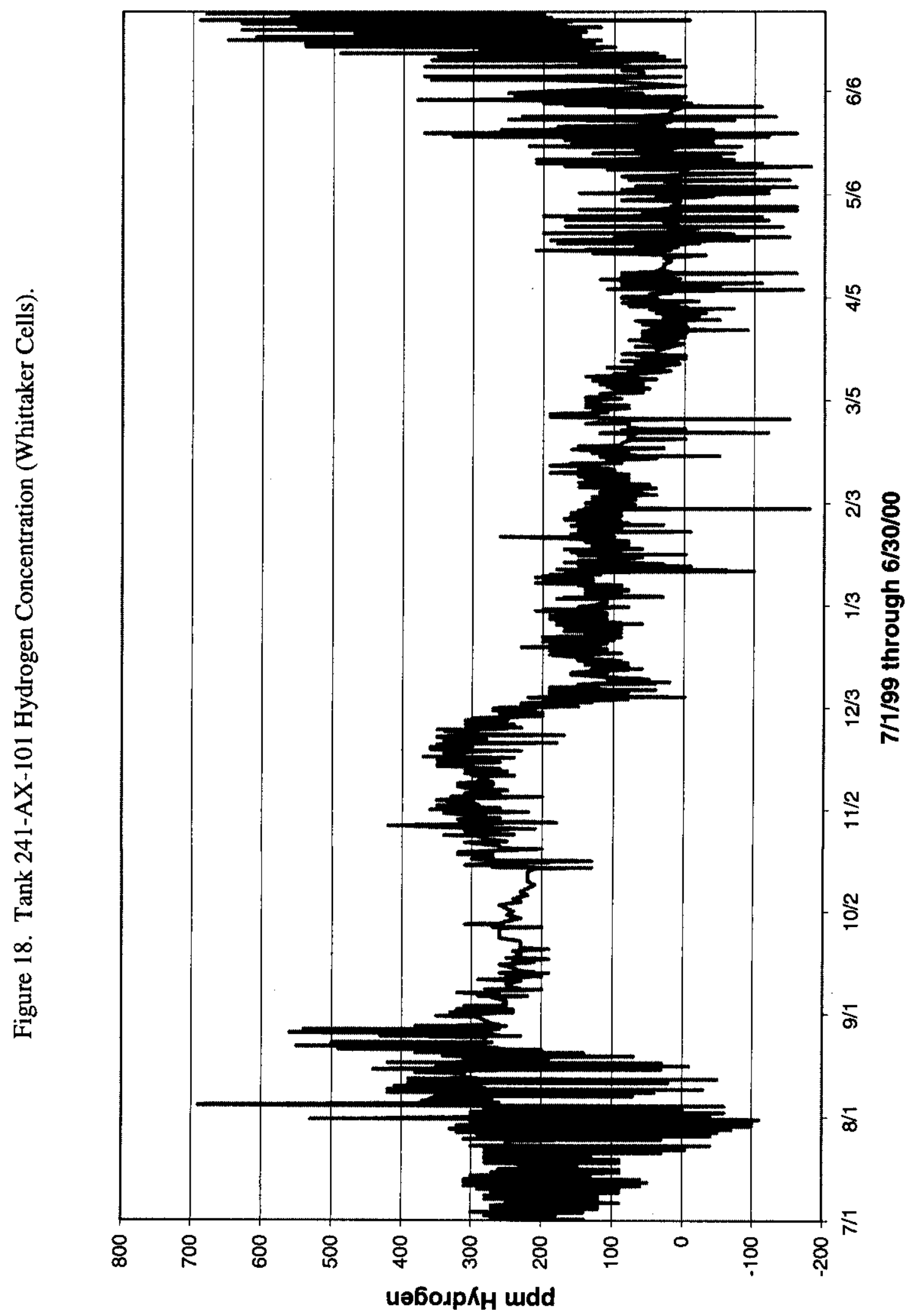




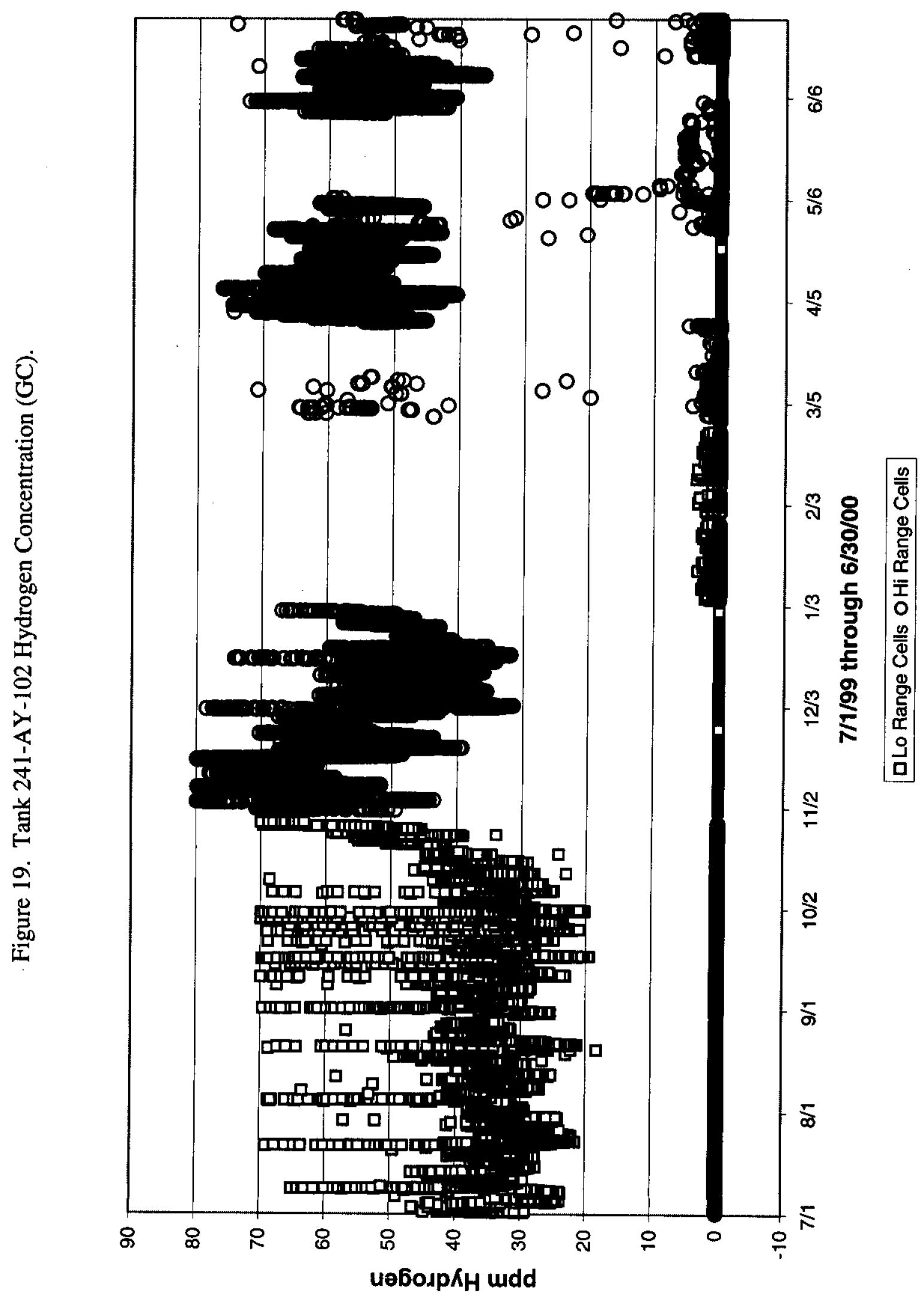


HNF-SD-WM-TI-797 REV 5

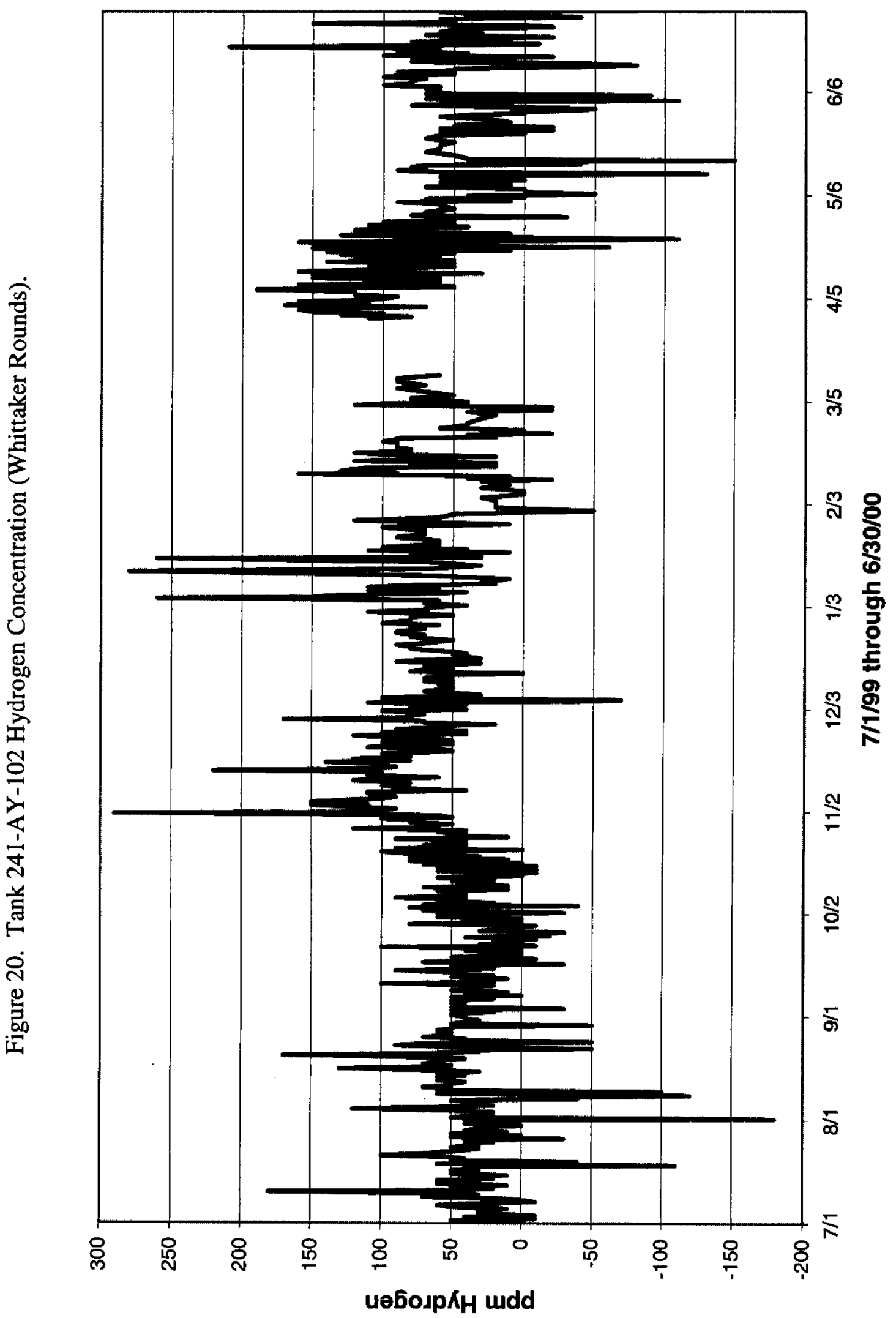


HNF-SD-WM-TI-797 REV 5

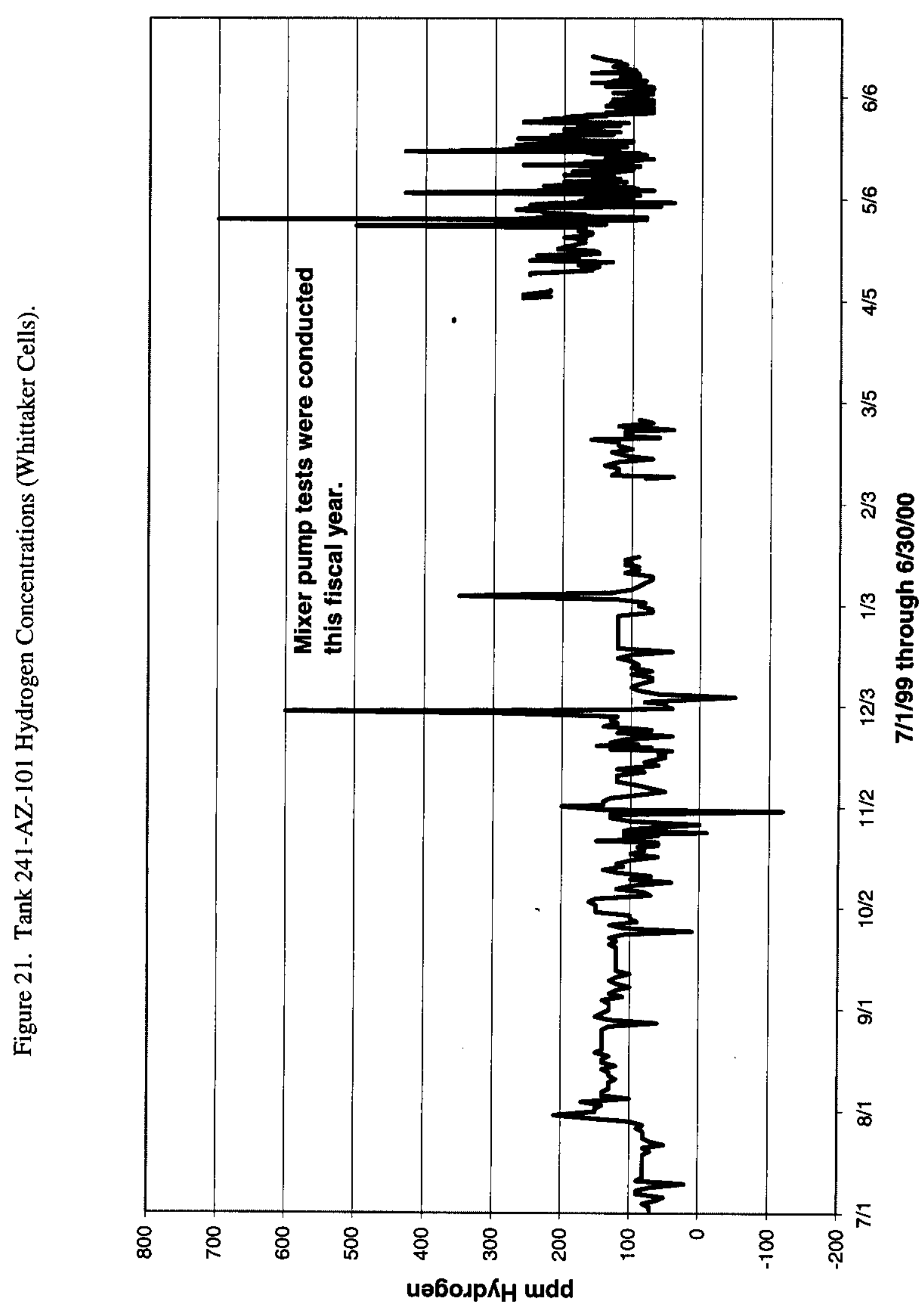


HNF-SD-WM-TI-797 REV 5

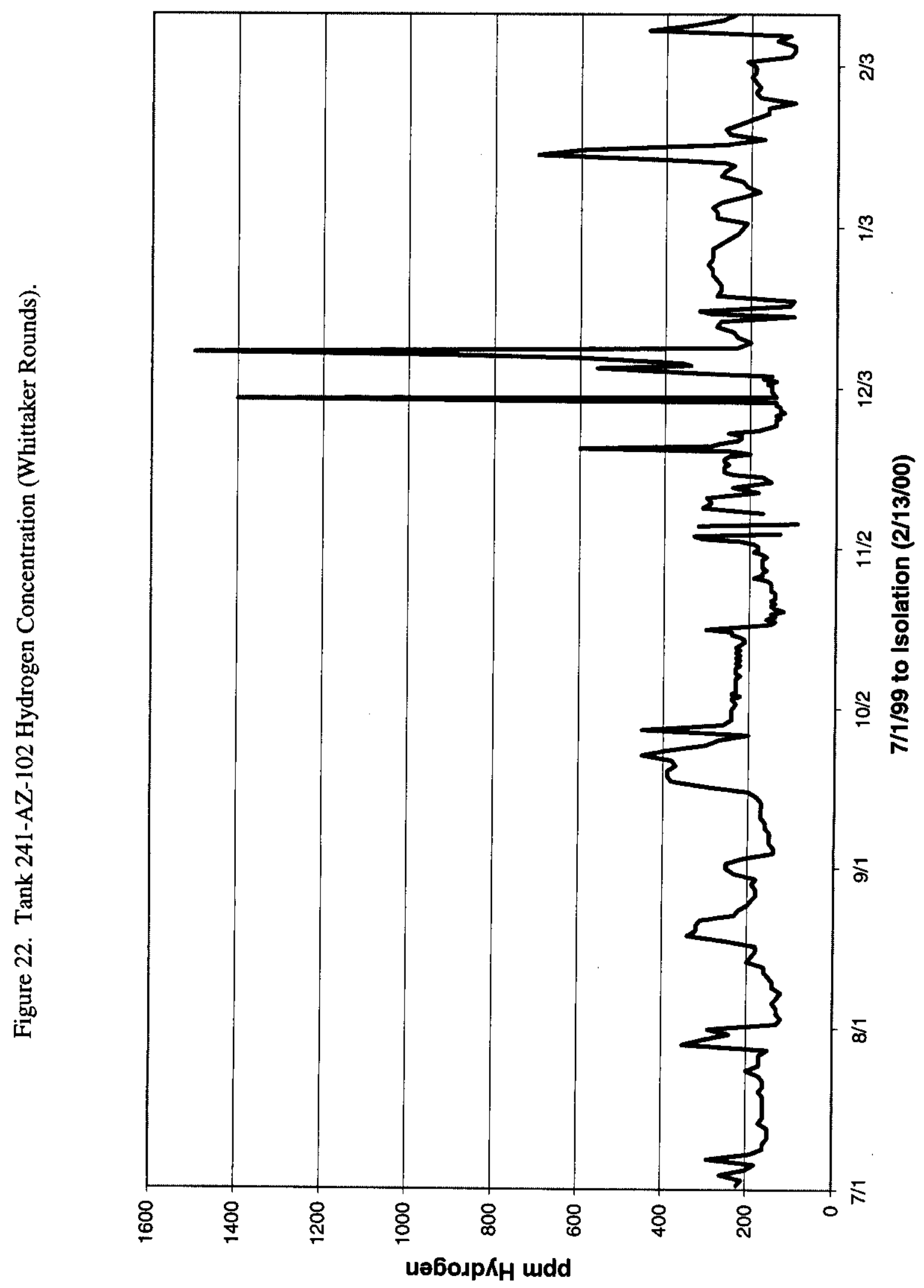


HNF-SD-WM-TI-797 REV 5

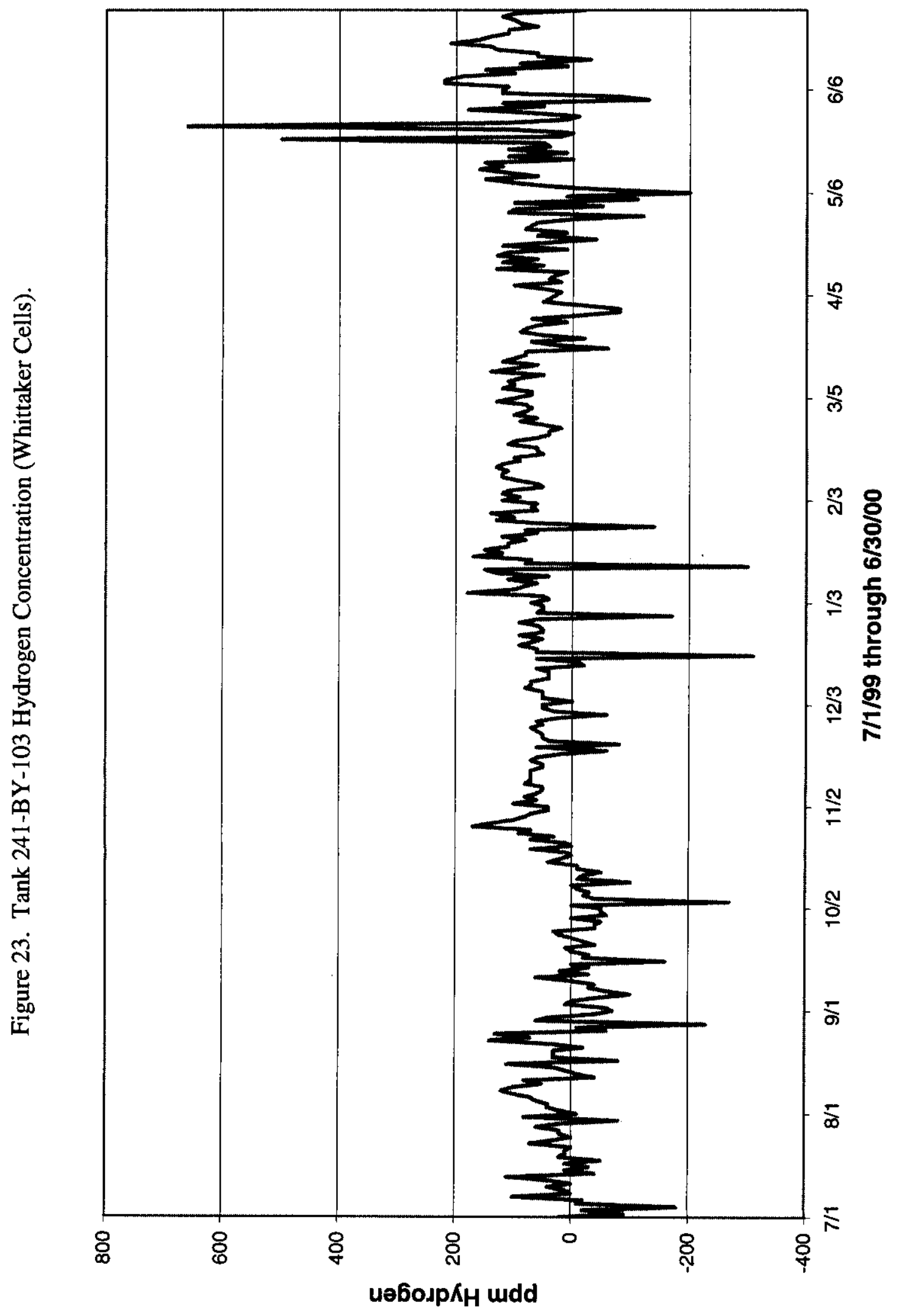


HNF-SD-WM-TI-797 REV 5

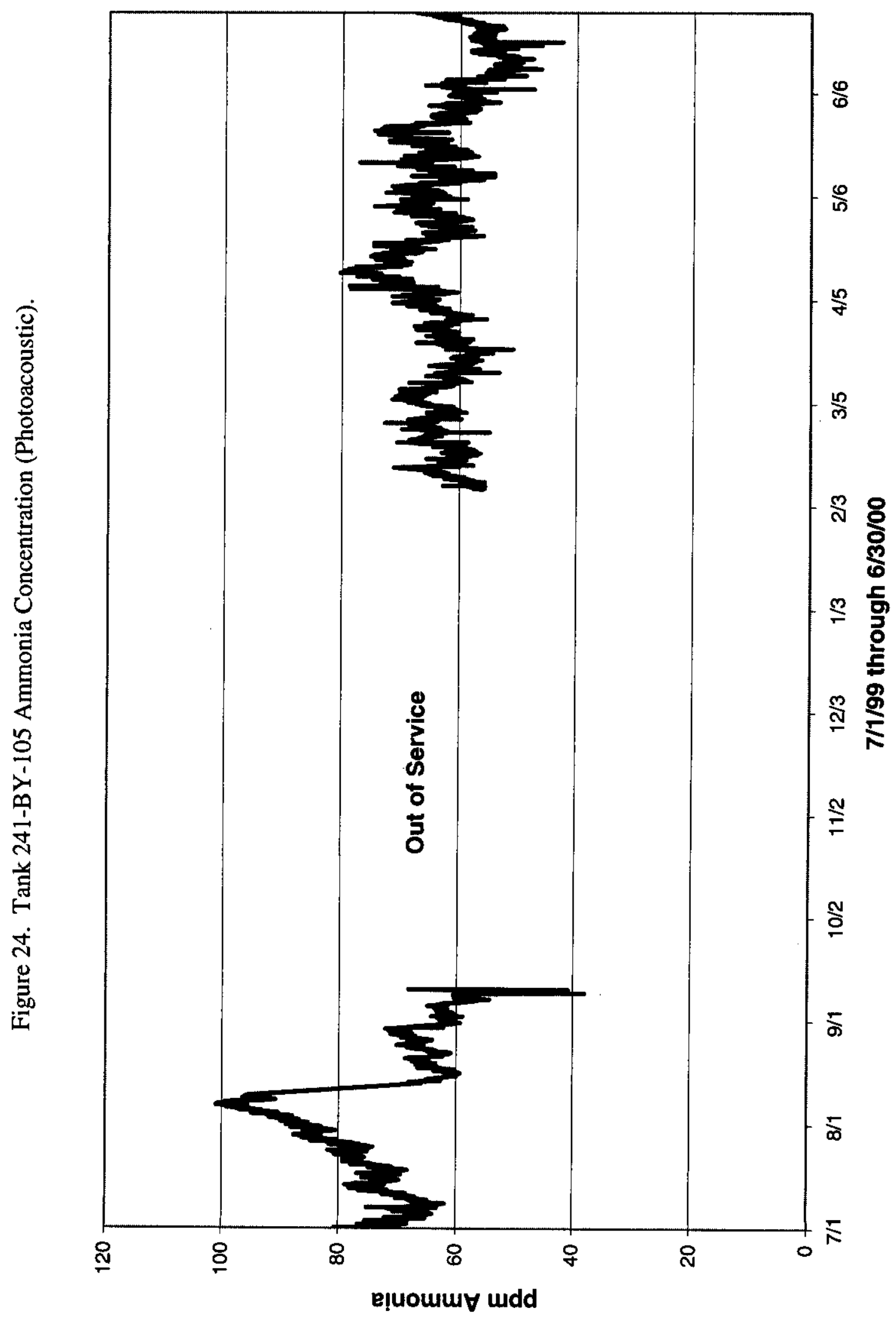




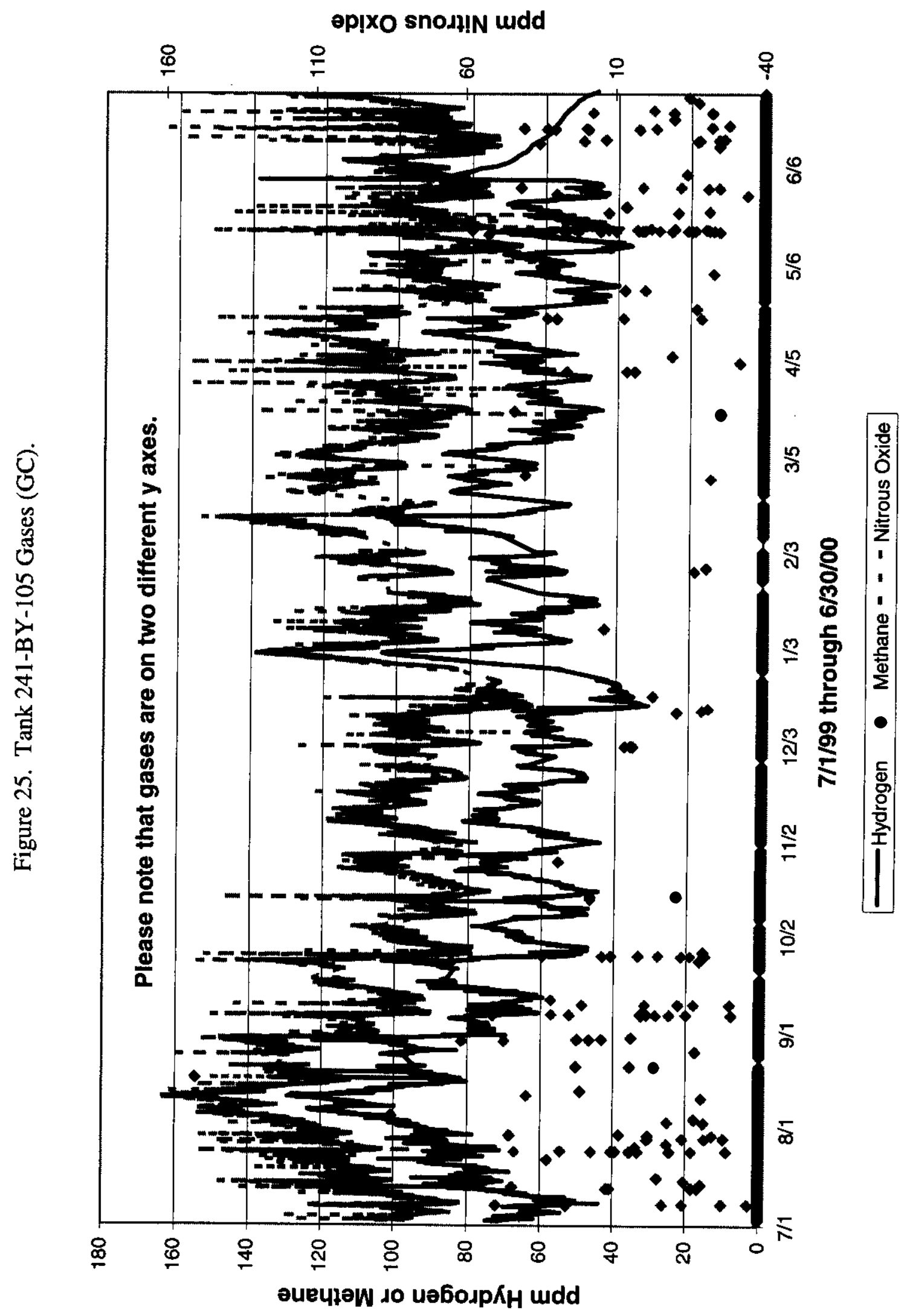


HNF-SD-WM-TI-797 REV 5

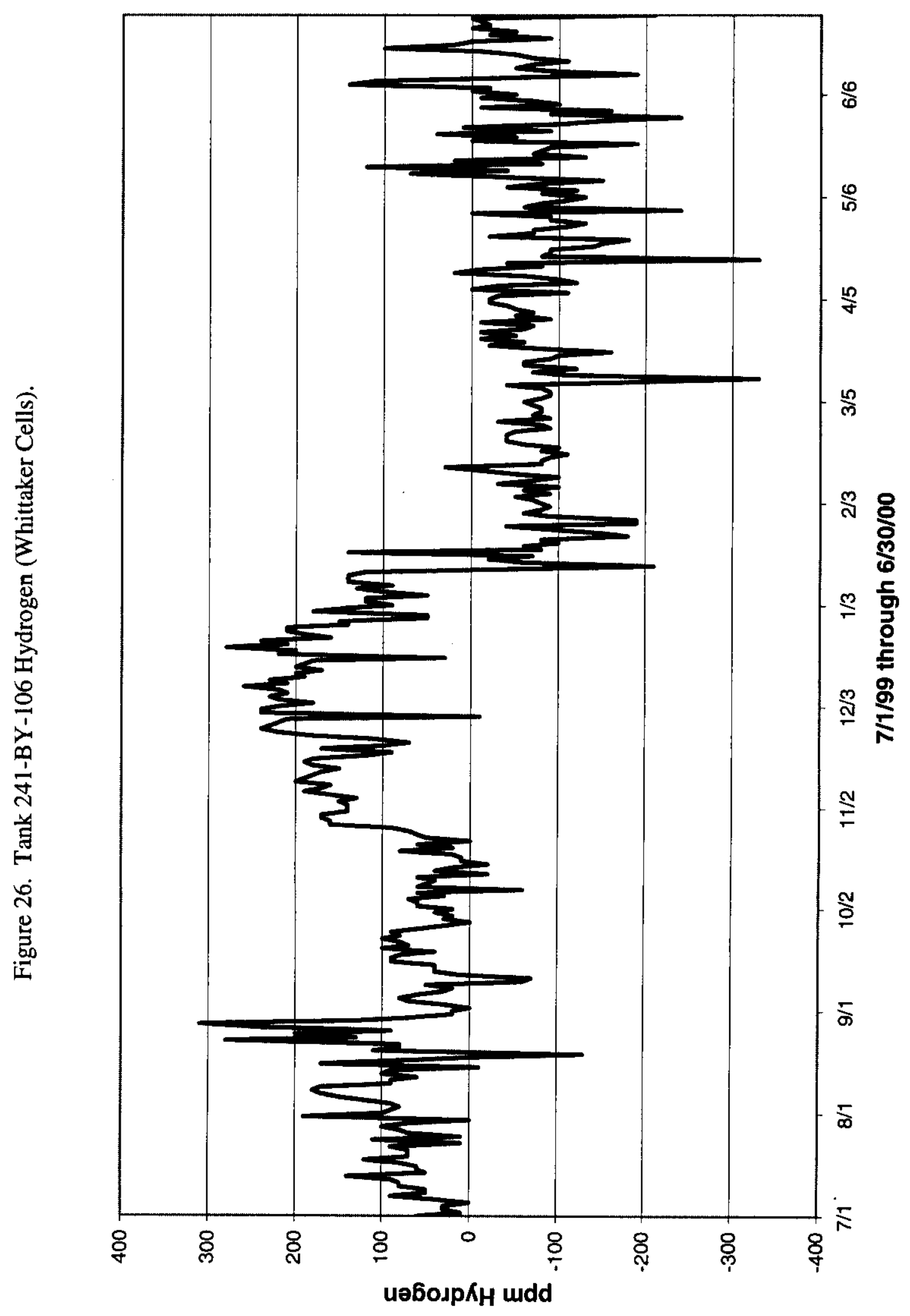


HNF-SD-WM-TI-797 REV 5

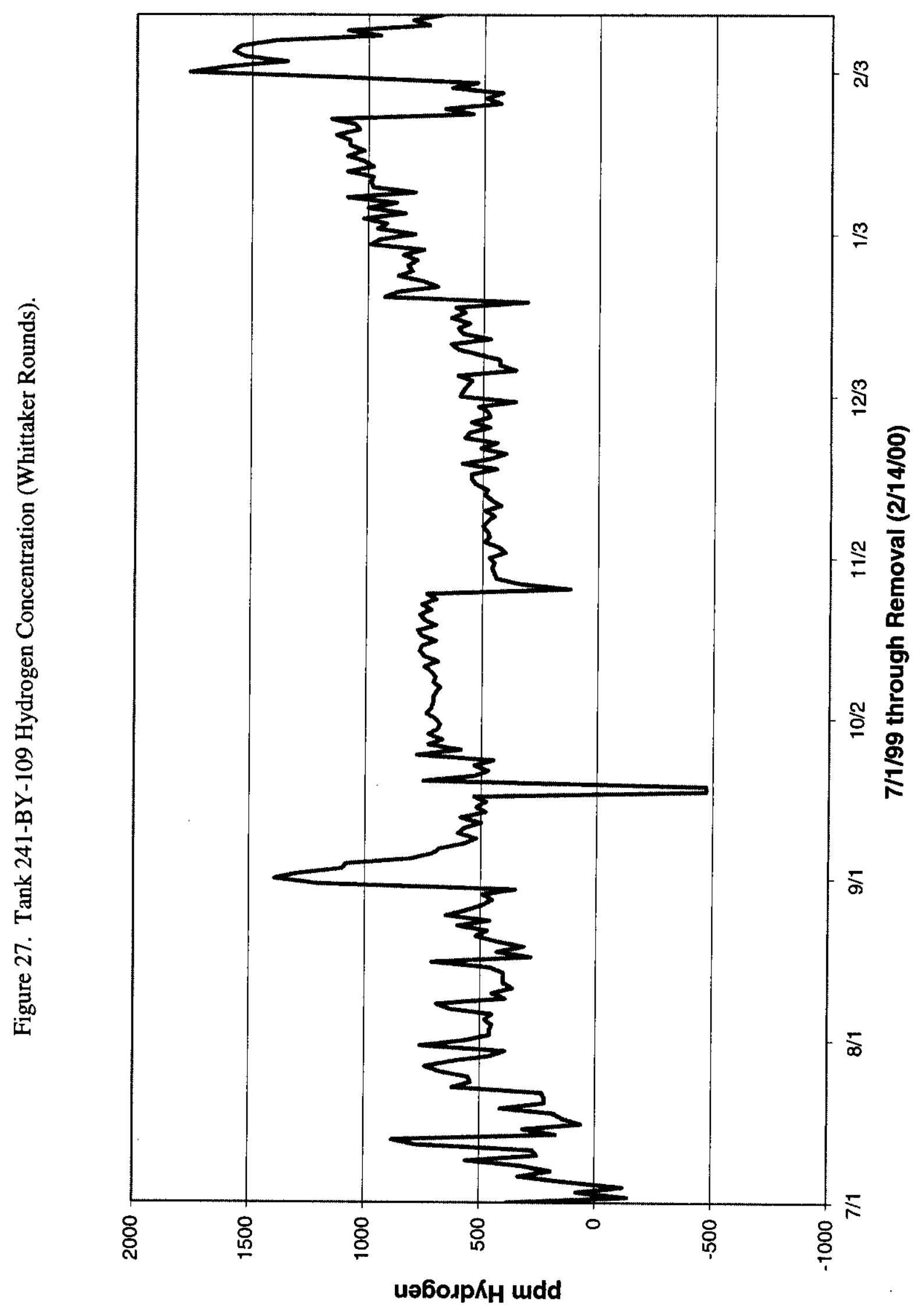


HNF-SD-WM-TI-797 REV 5

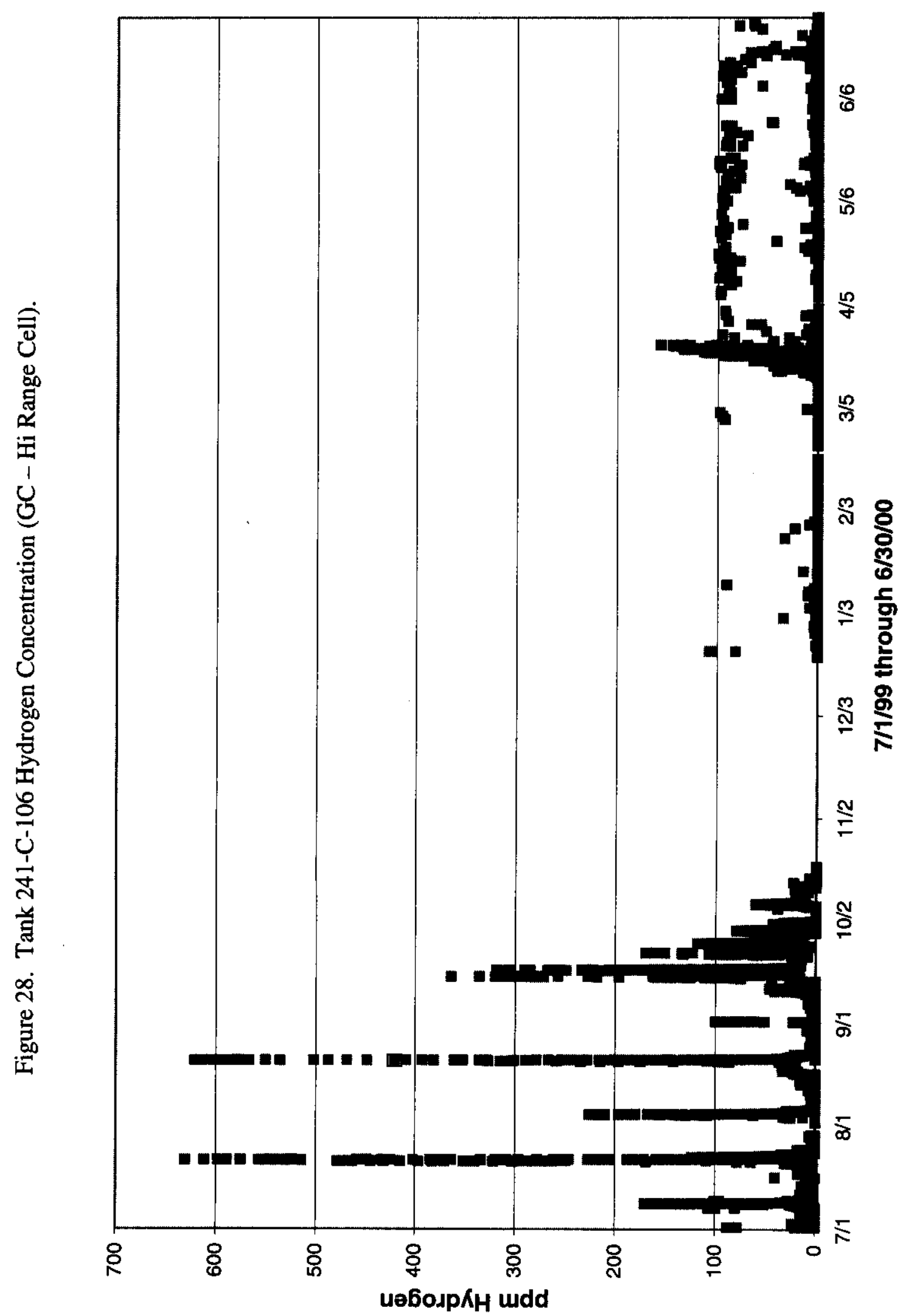


HNF-SD-WM-TI-797 REV 5

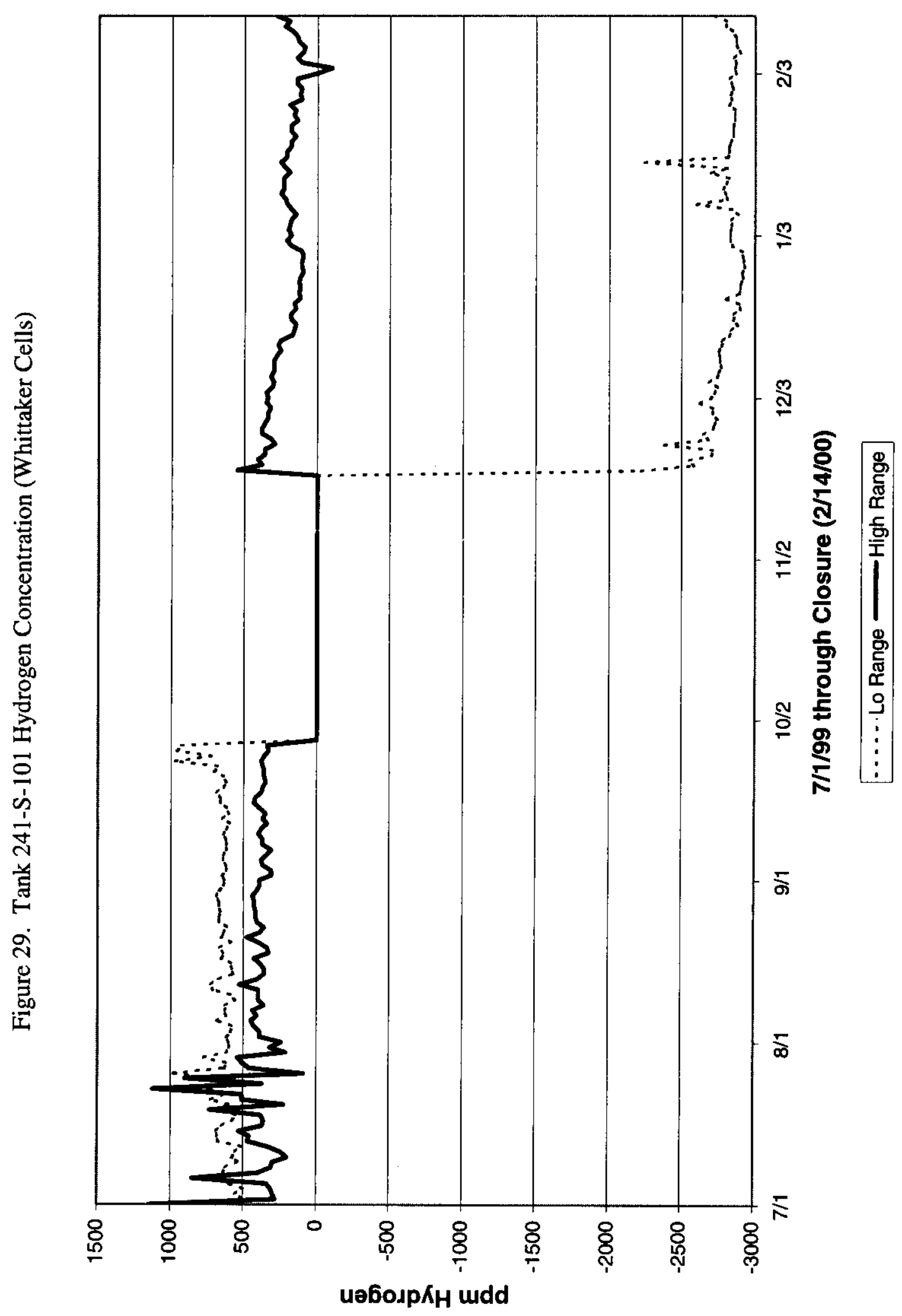




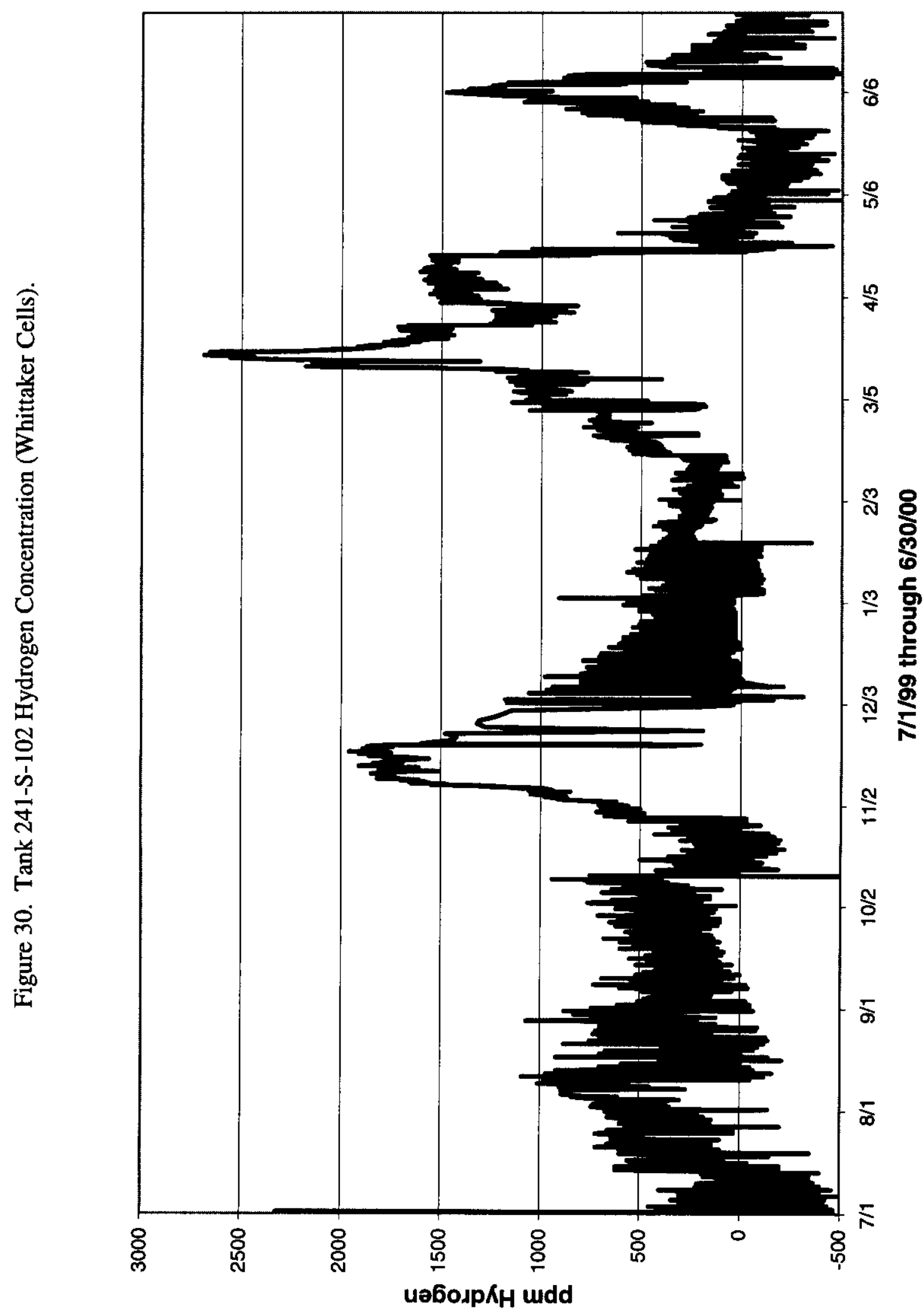


HNF-SD-WM-TI-797 REV 5

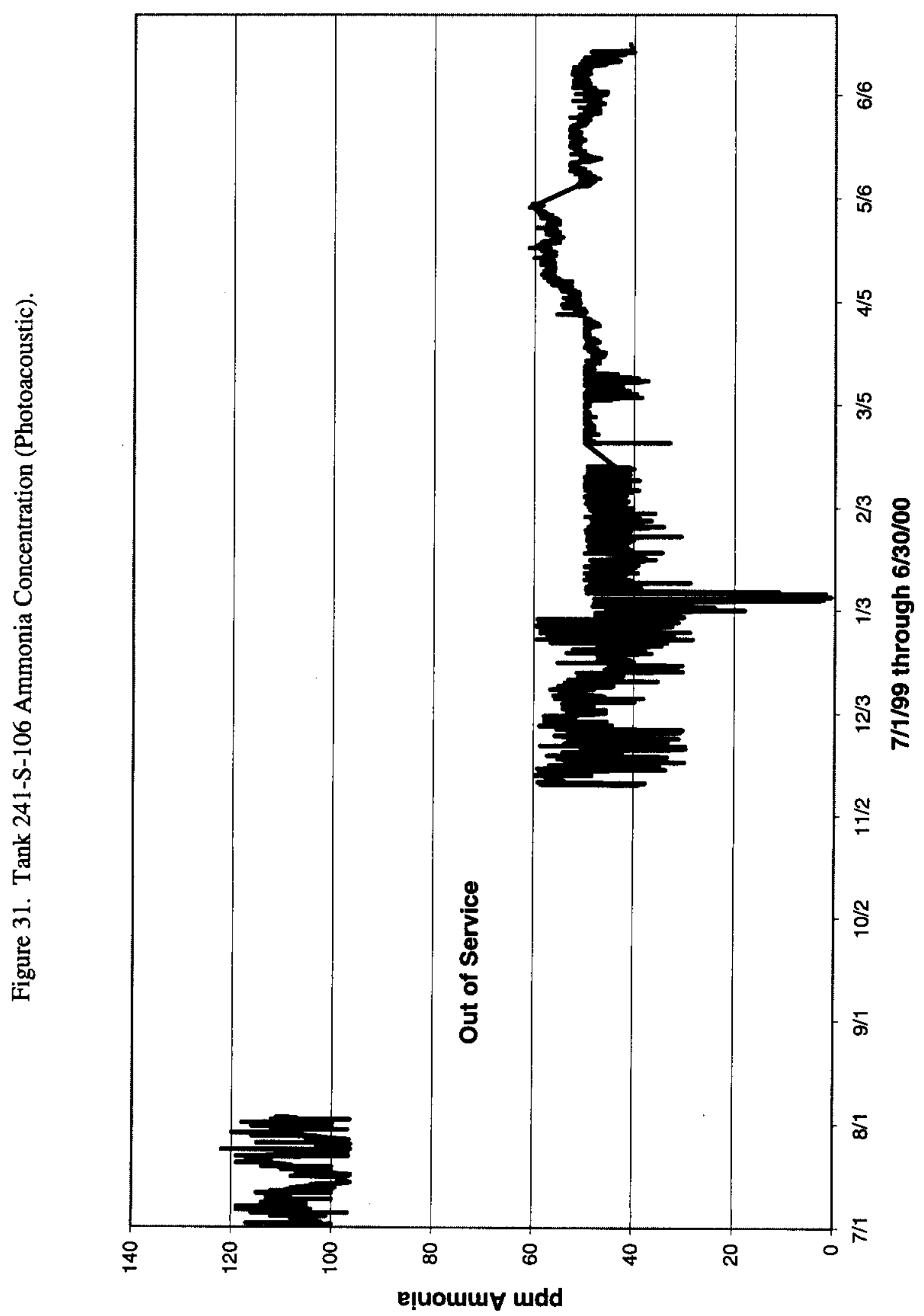




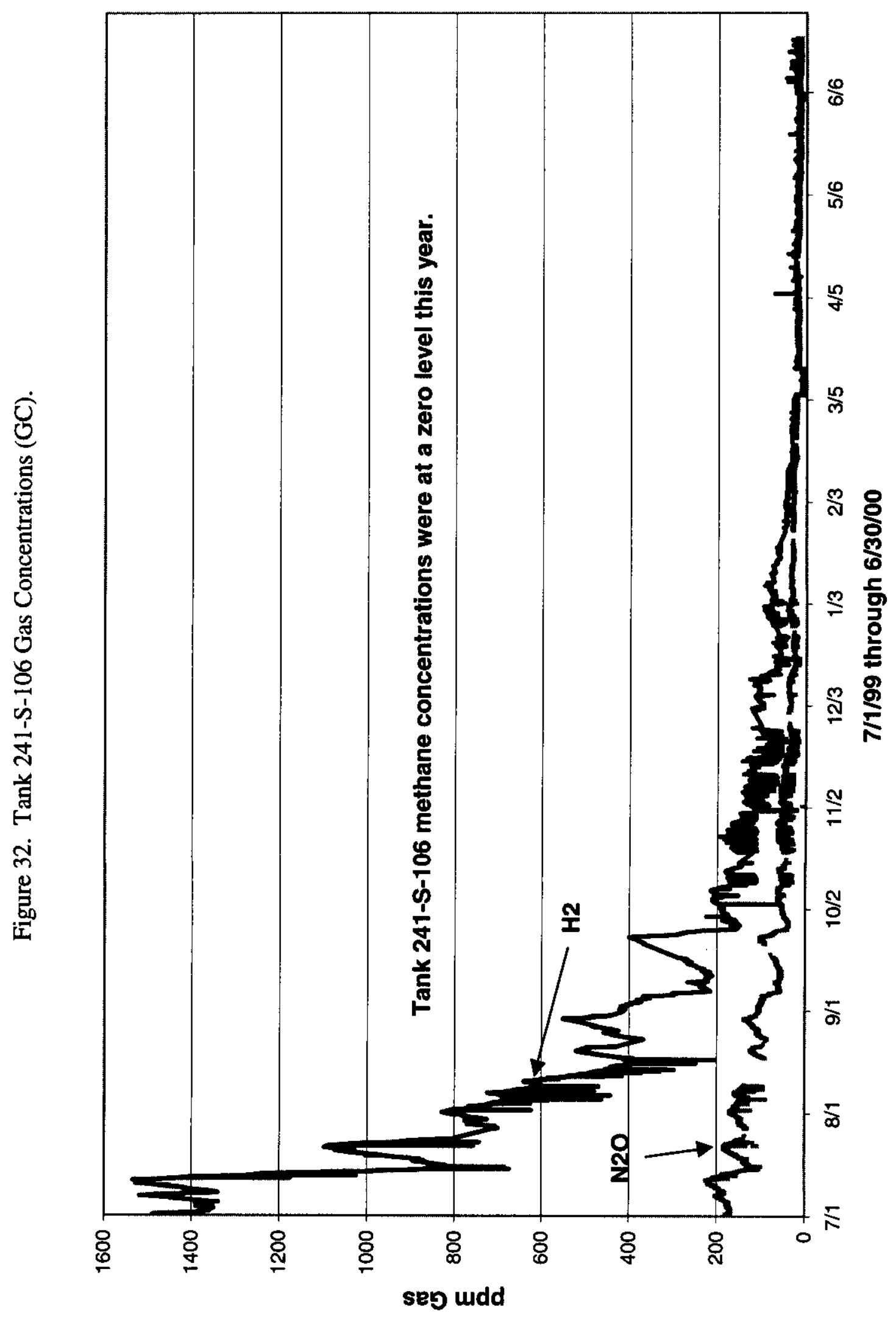


HNF-SD-WM-TI-797 REV 5

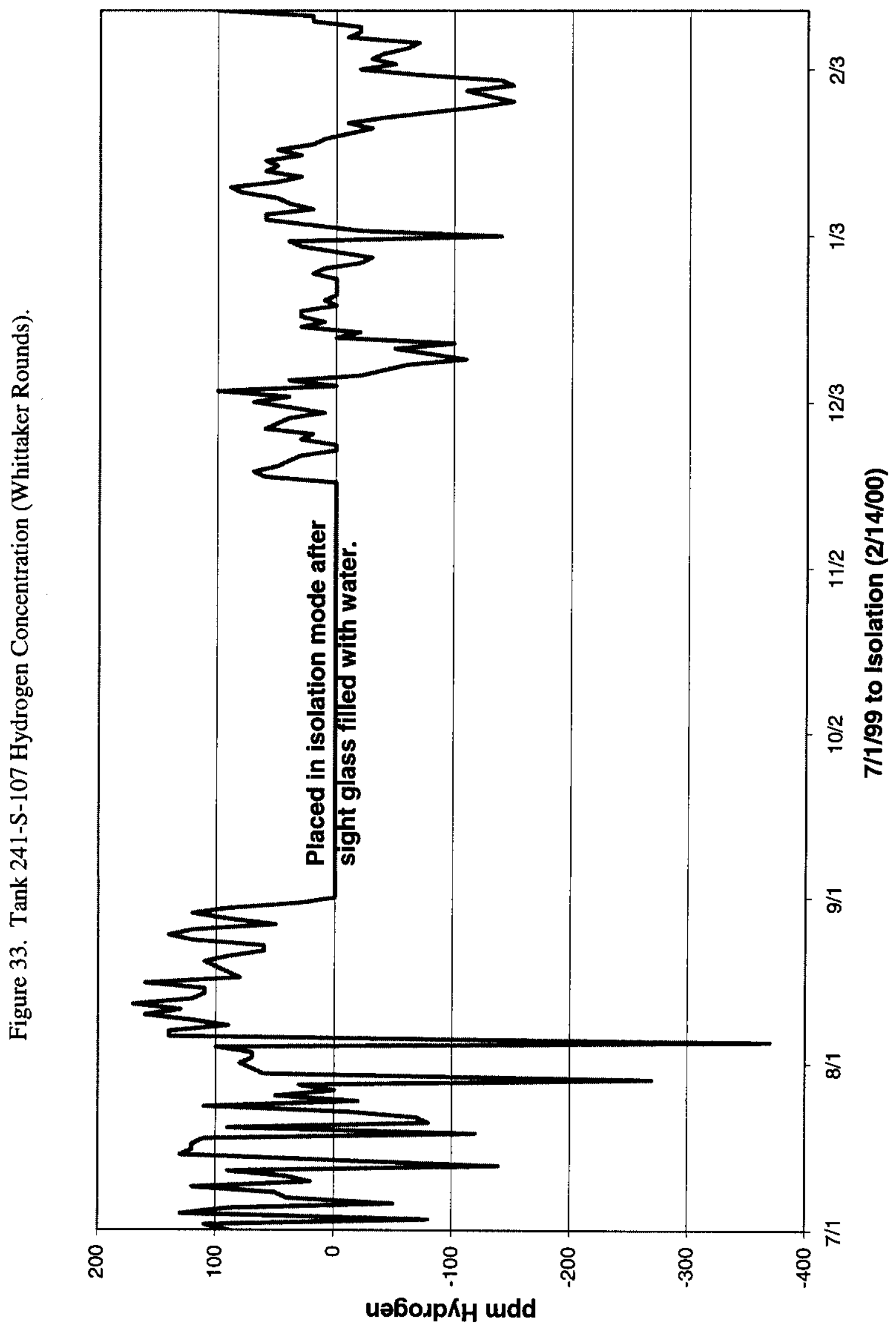


HNF-SD-WM-TI-797 REV 5

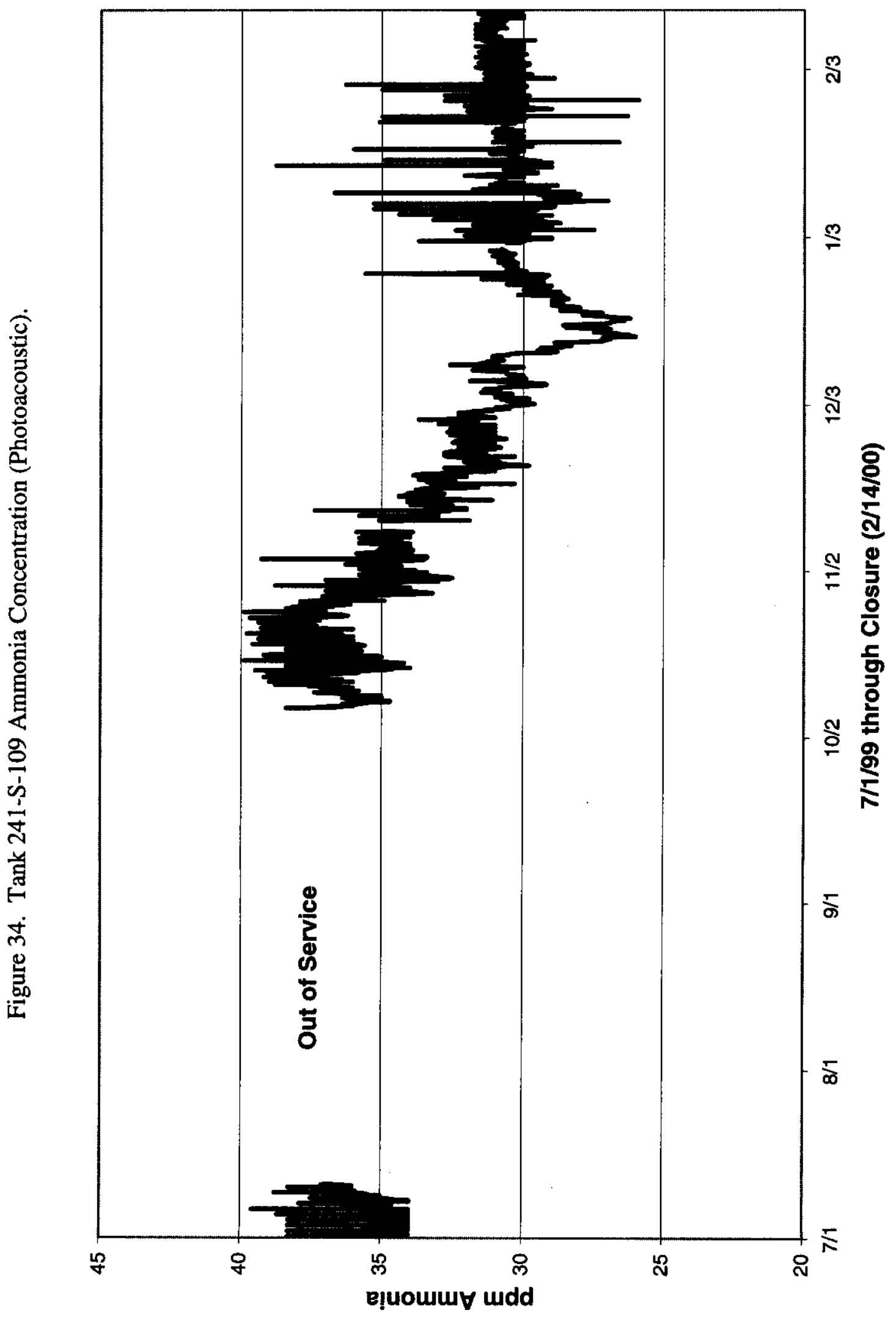




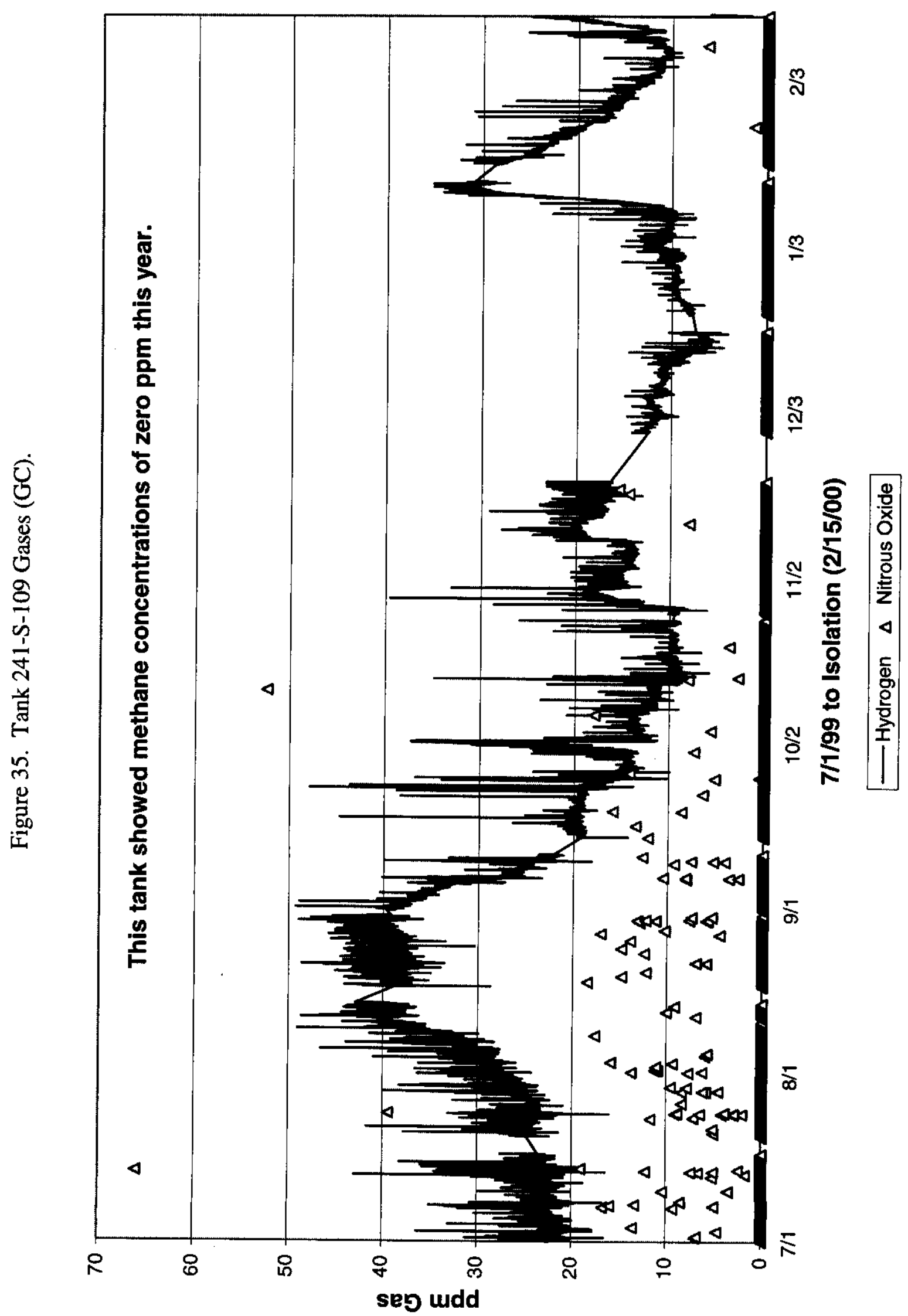




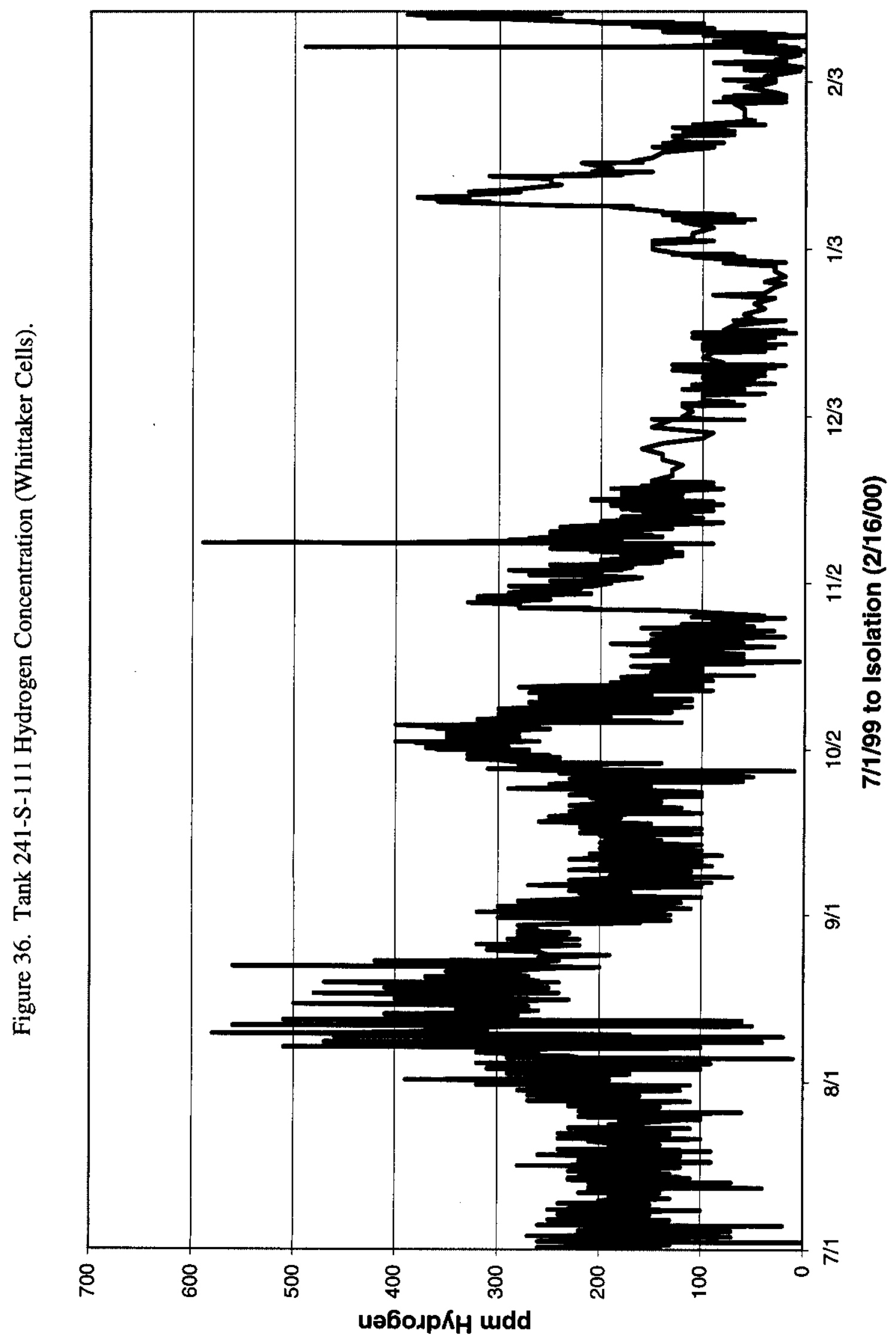


HNF-SD-WM-TI-797 REV 5

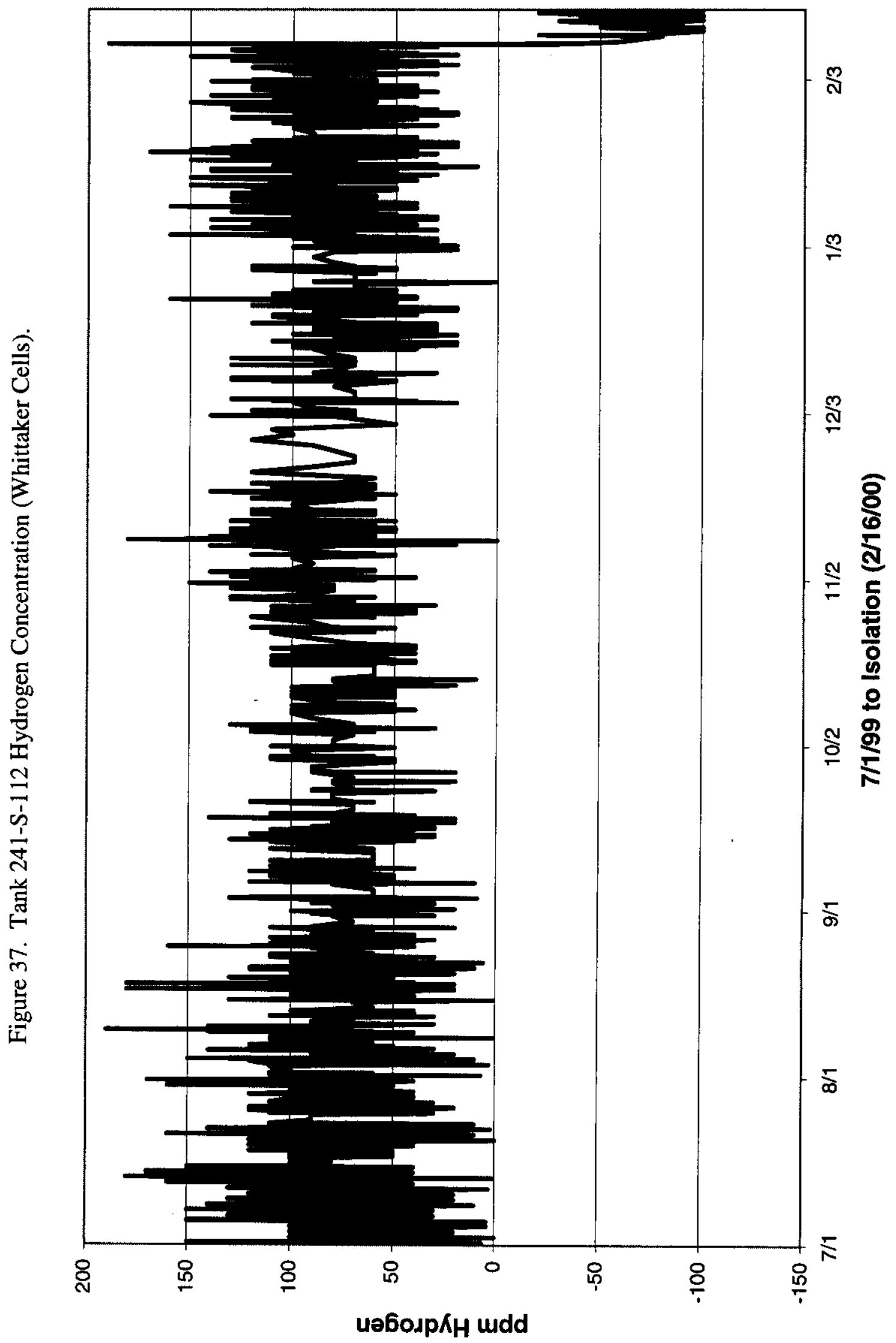




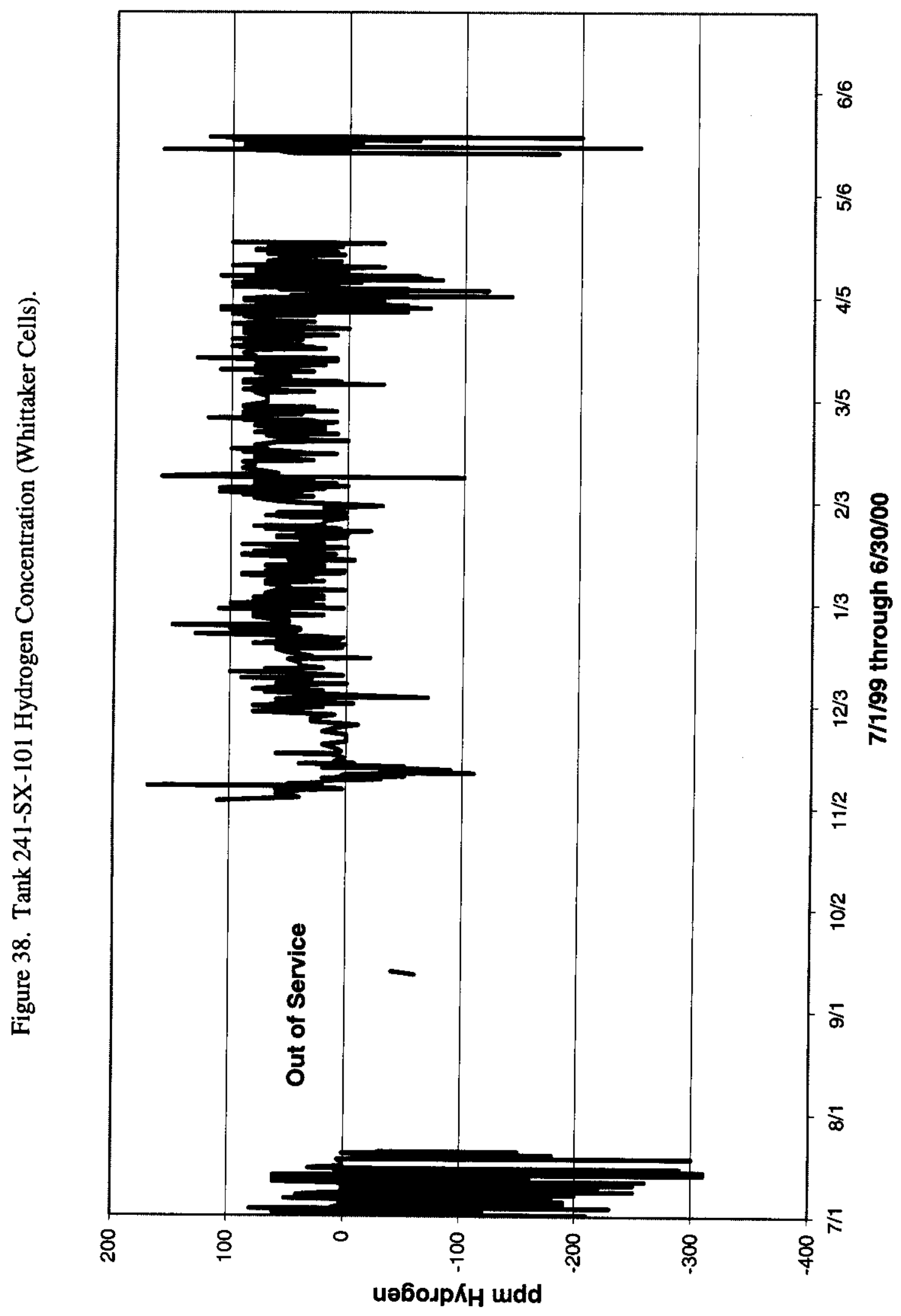


HNF-SD-WM-TI-797 REV 5

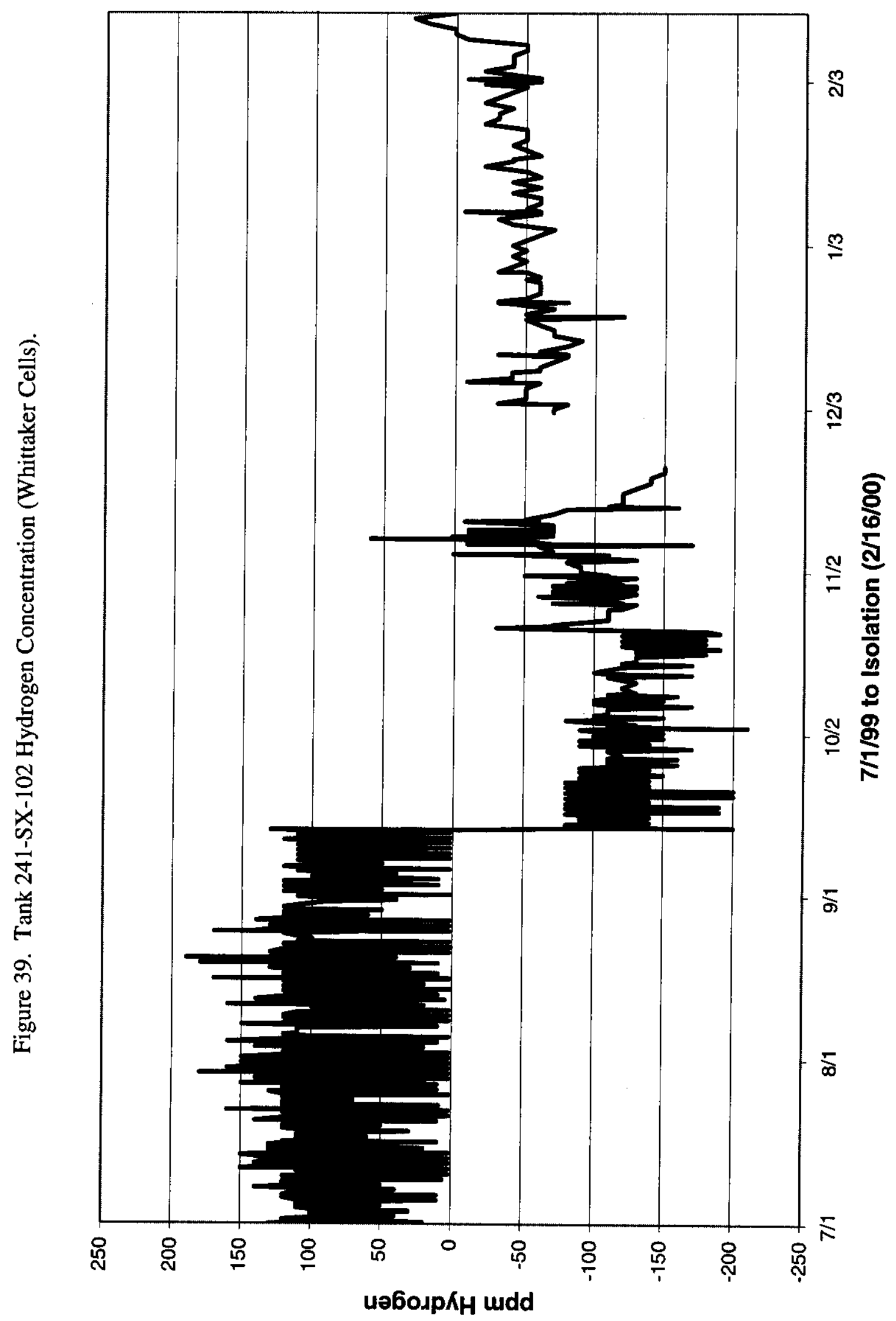




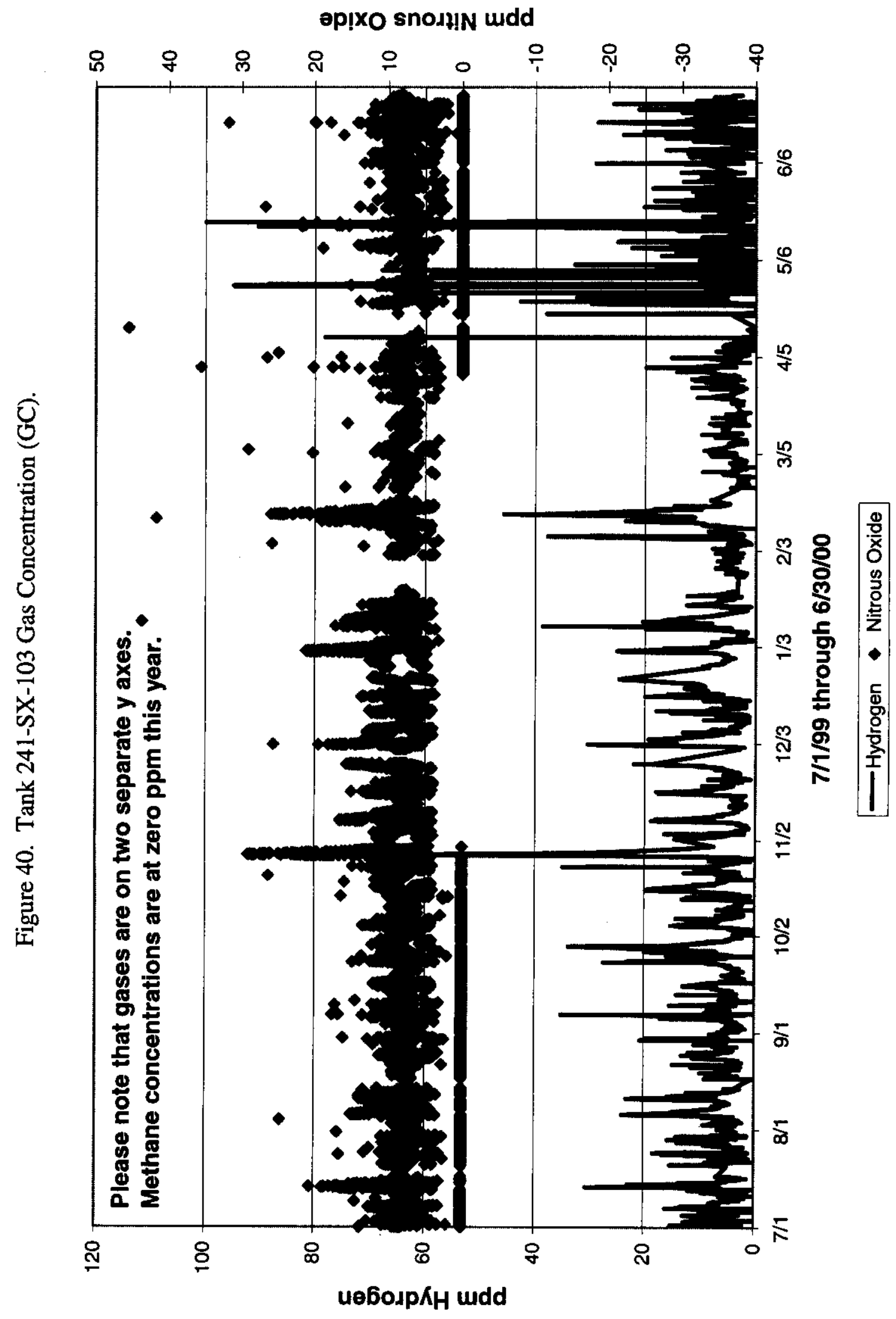




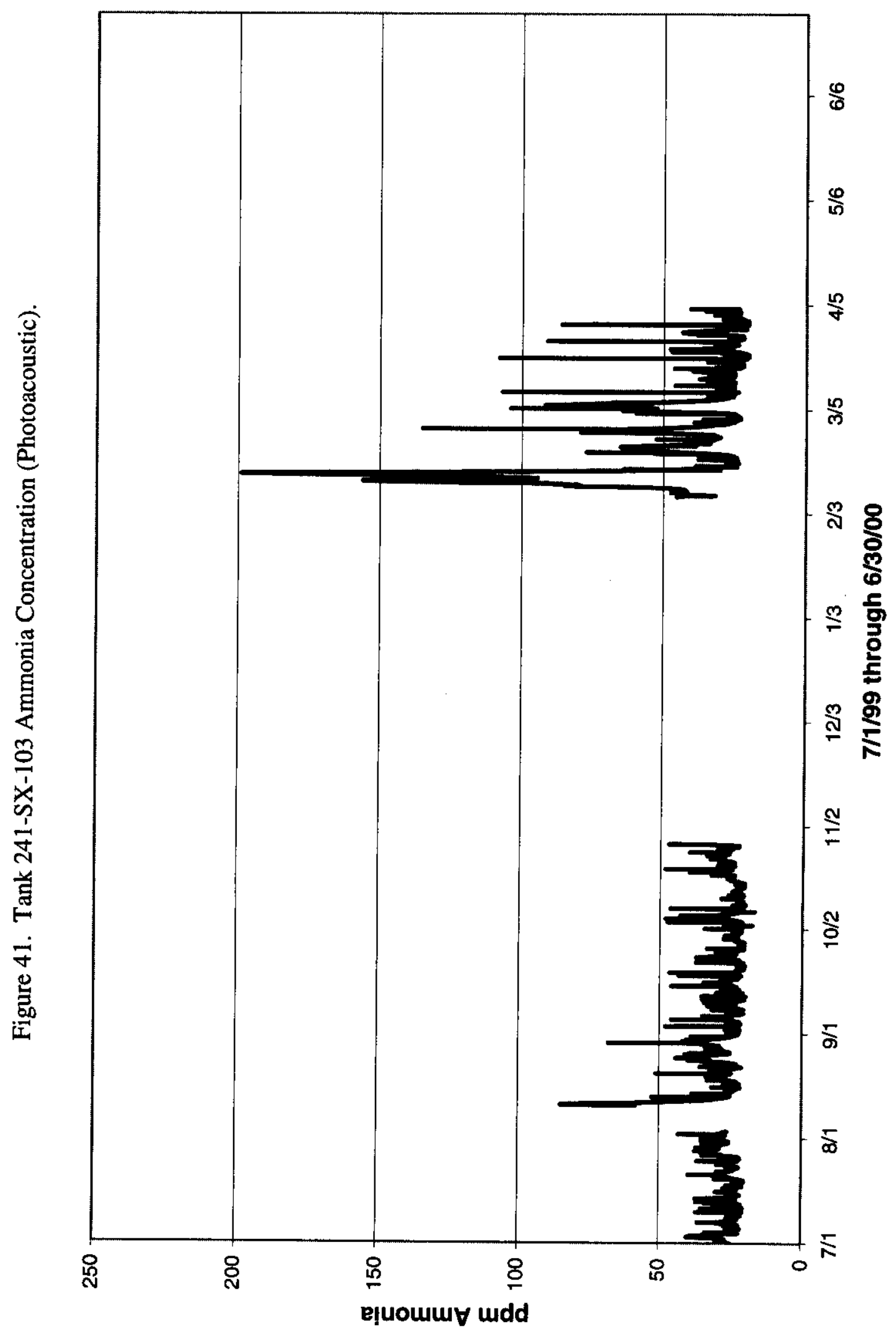


HNF-SD-WM-TI-797 REV 5

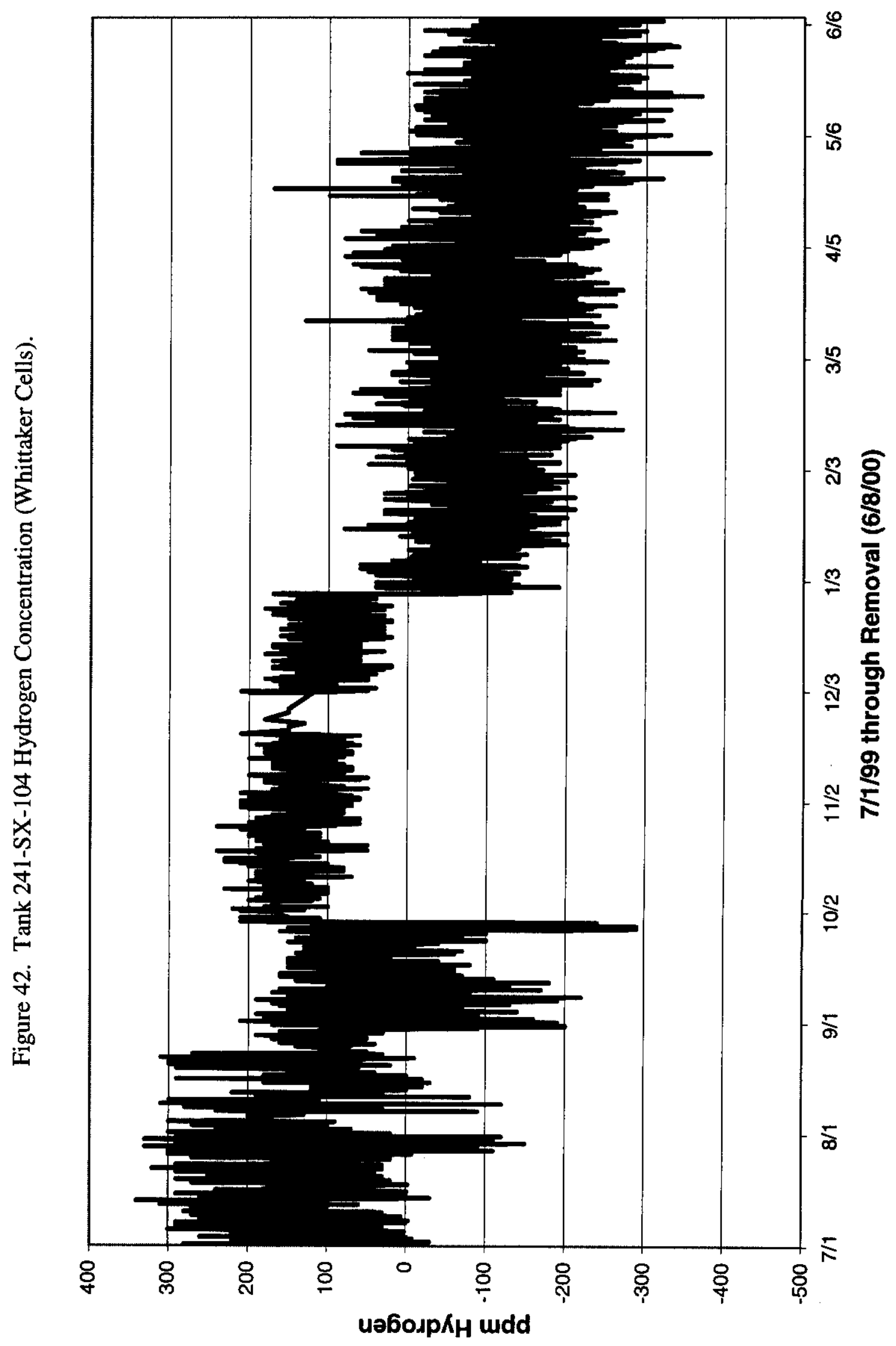




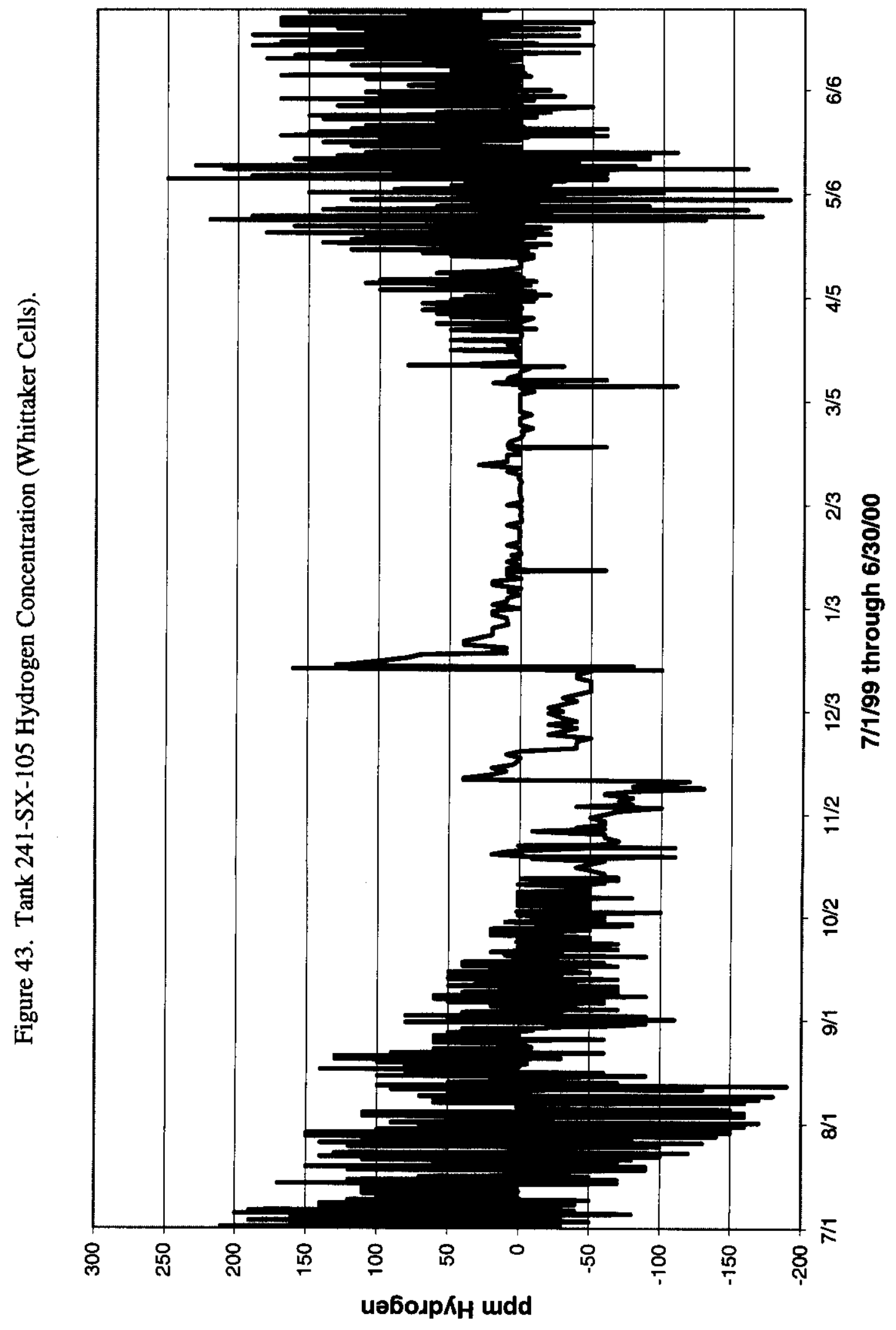


HNF-SD-WM-TI-797 REV 5

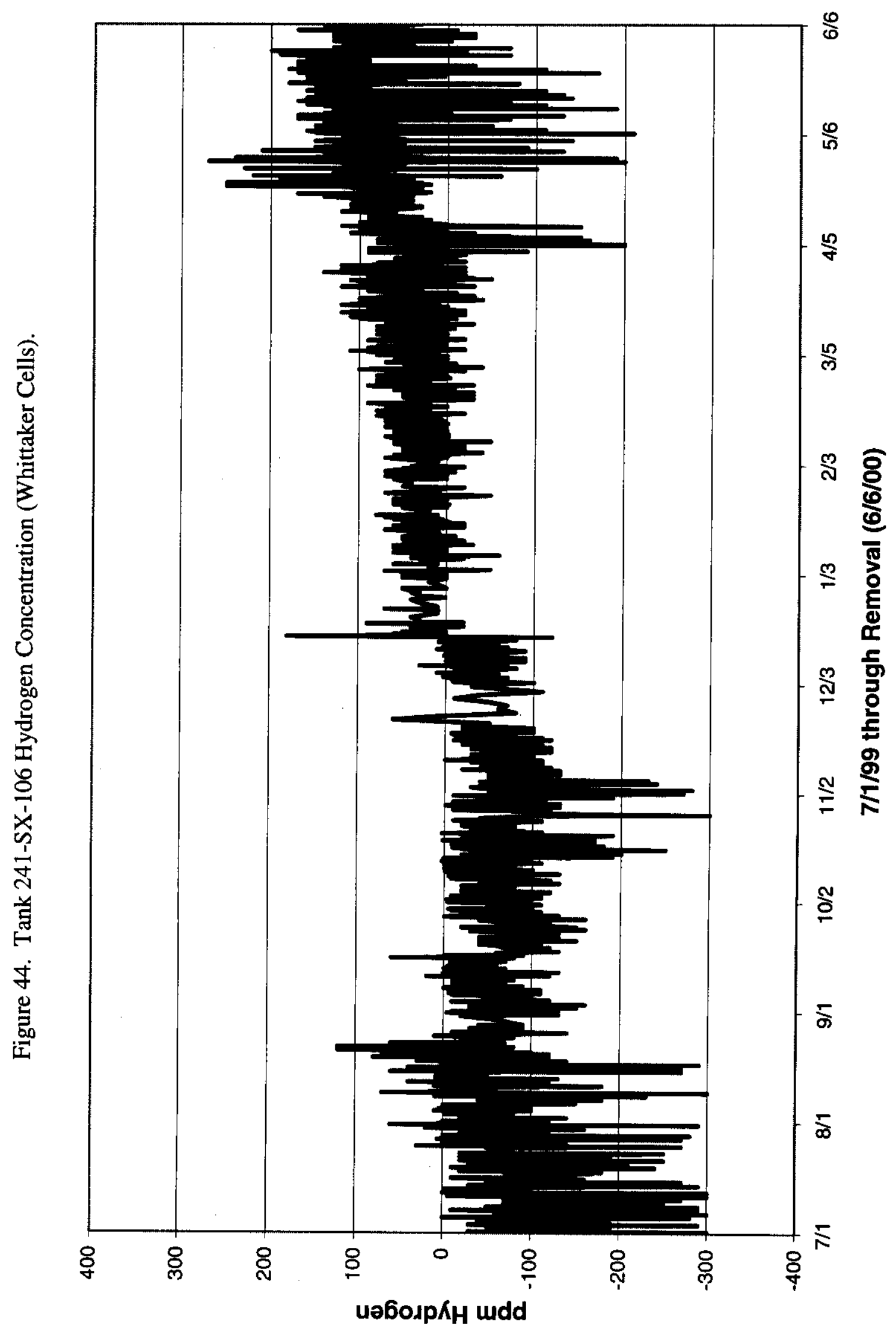


HNF-SD-WM-TI-797 REV 5

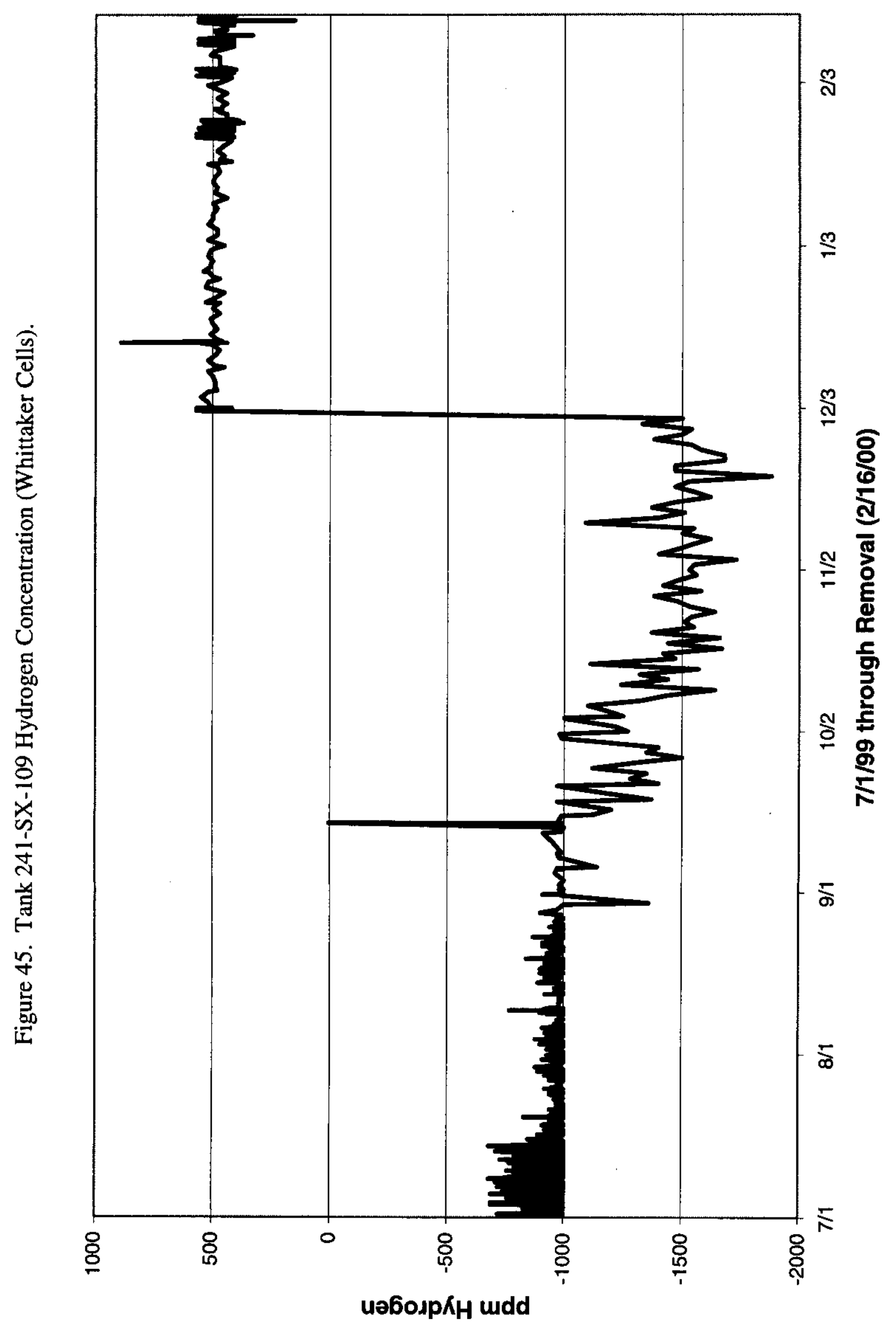




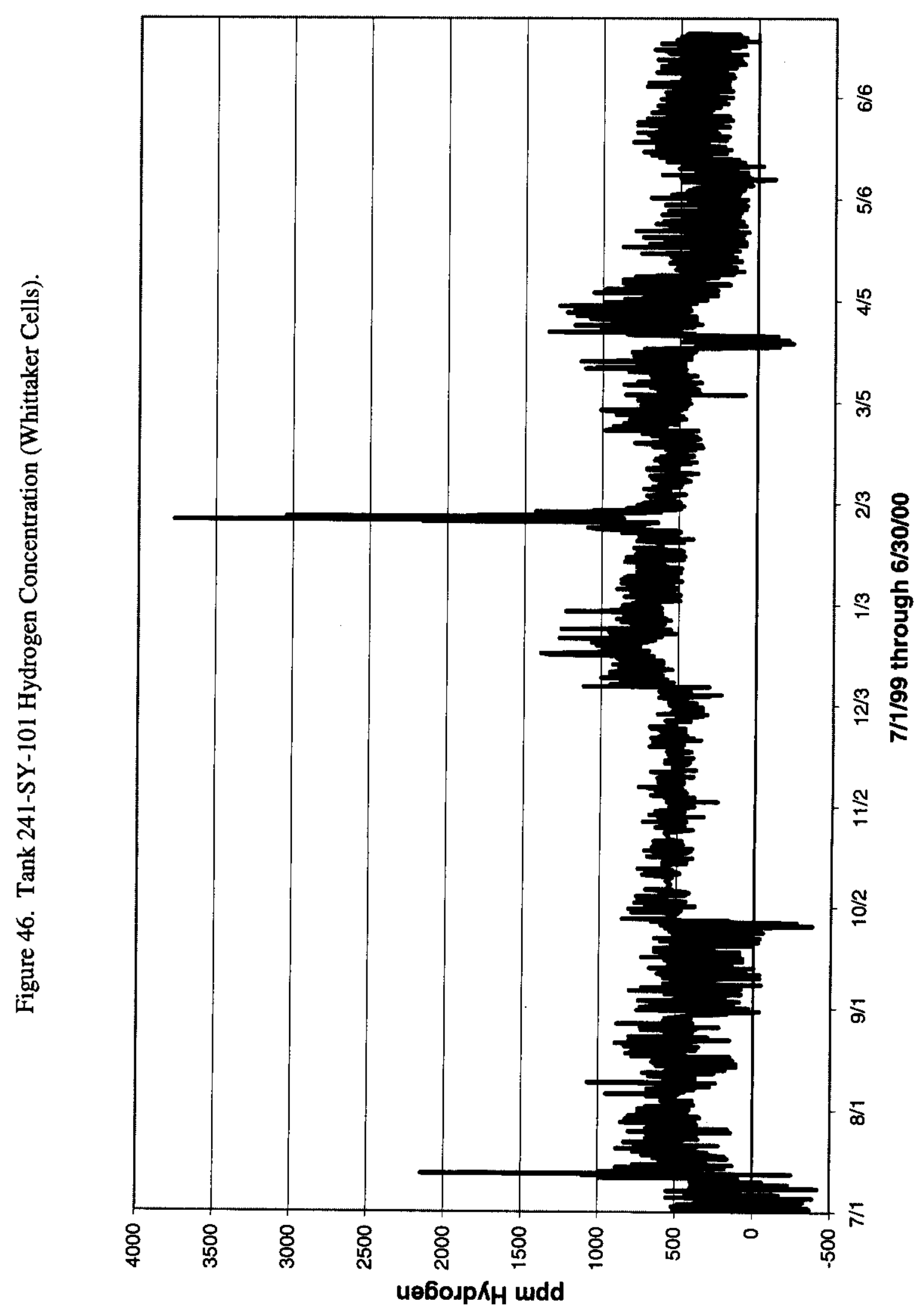


HNF-SD-WM-TI-797 REV 5

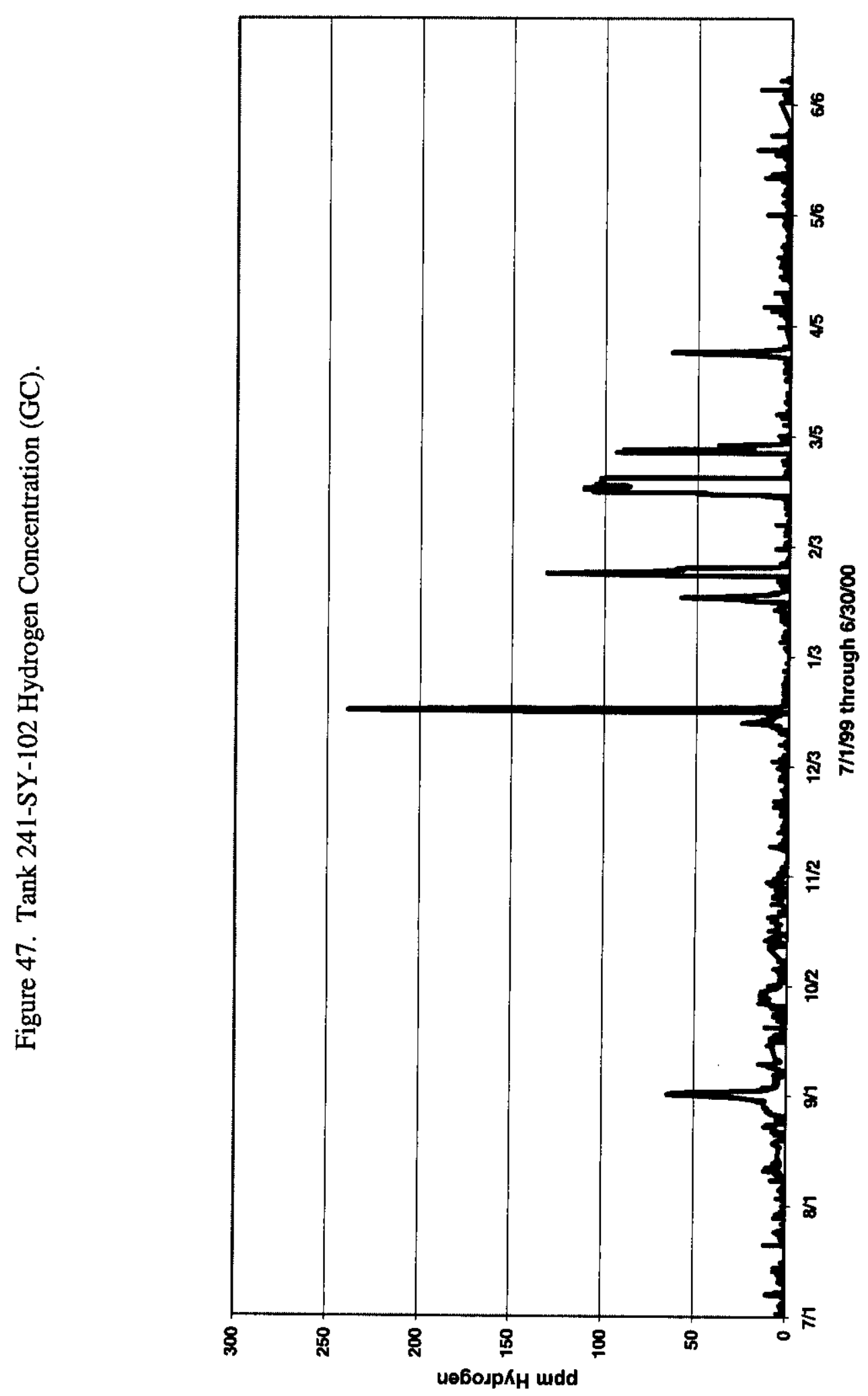


HNF-SD-WM-TI-797 REV 5

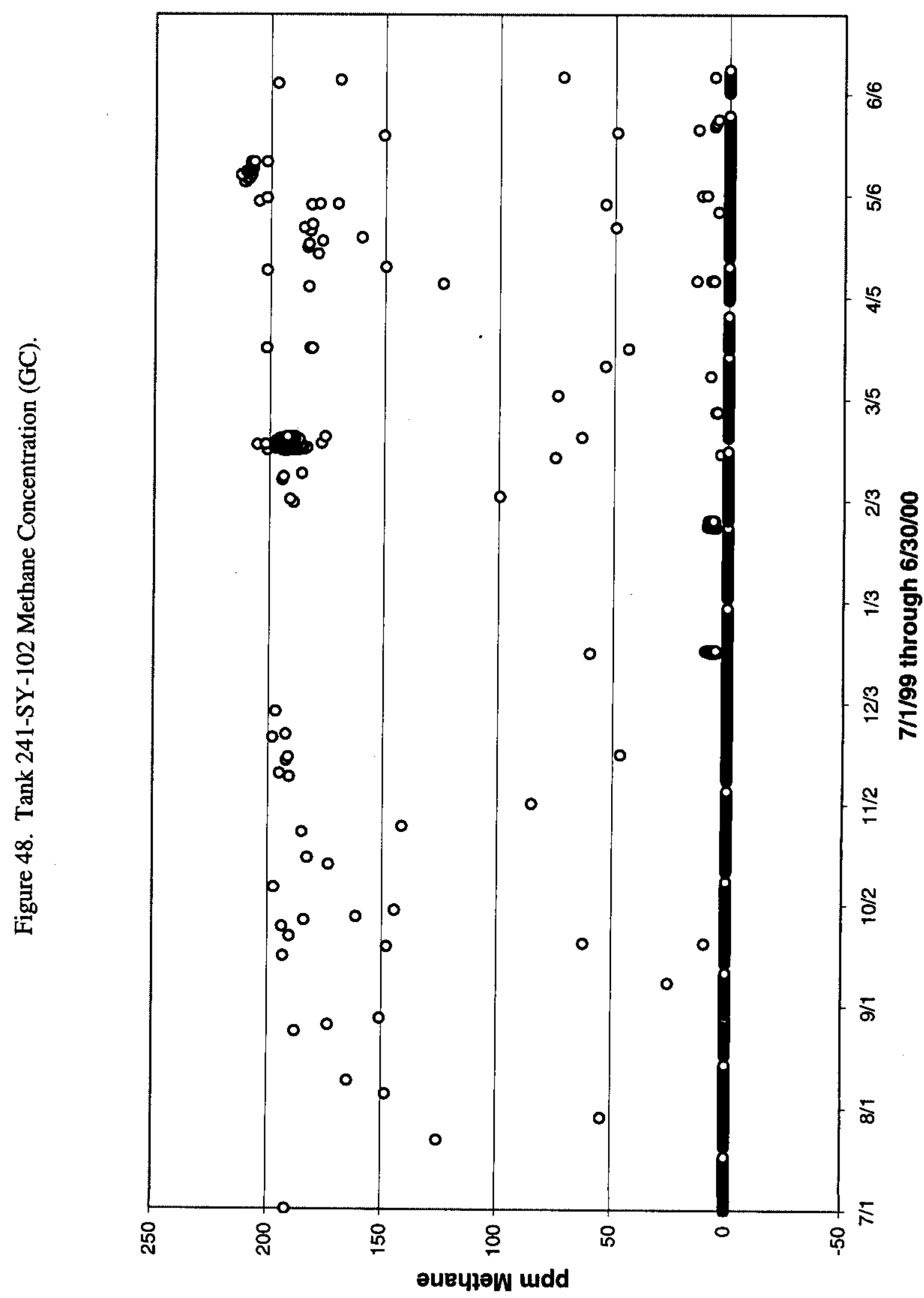


HNF-SD-WM-TI-797 REV 5

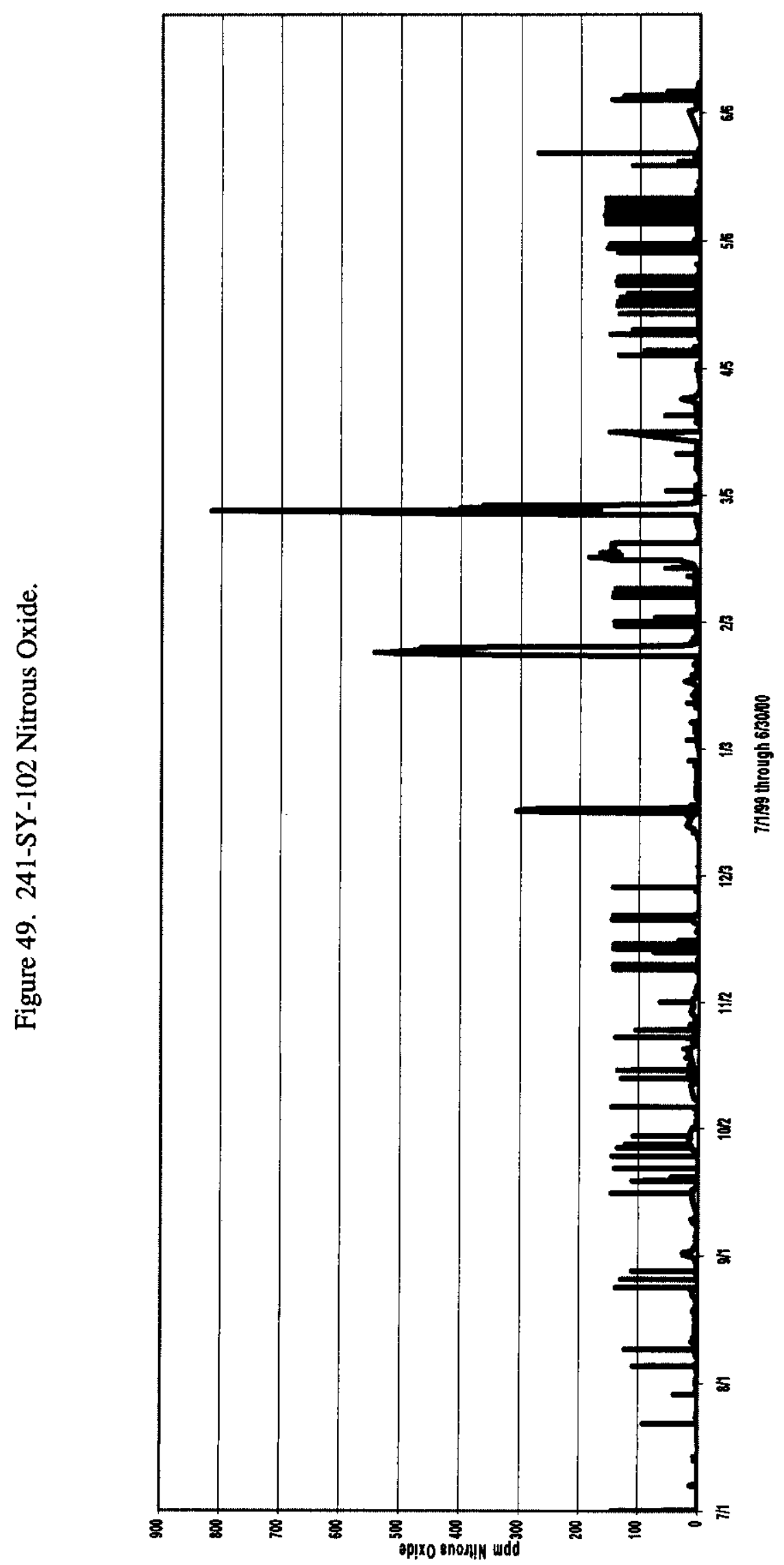




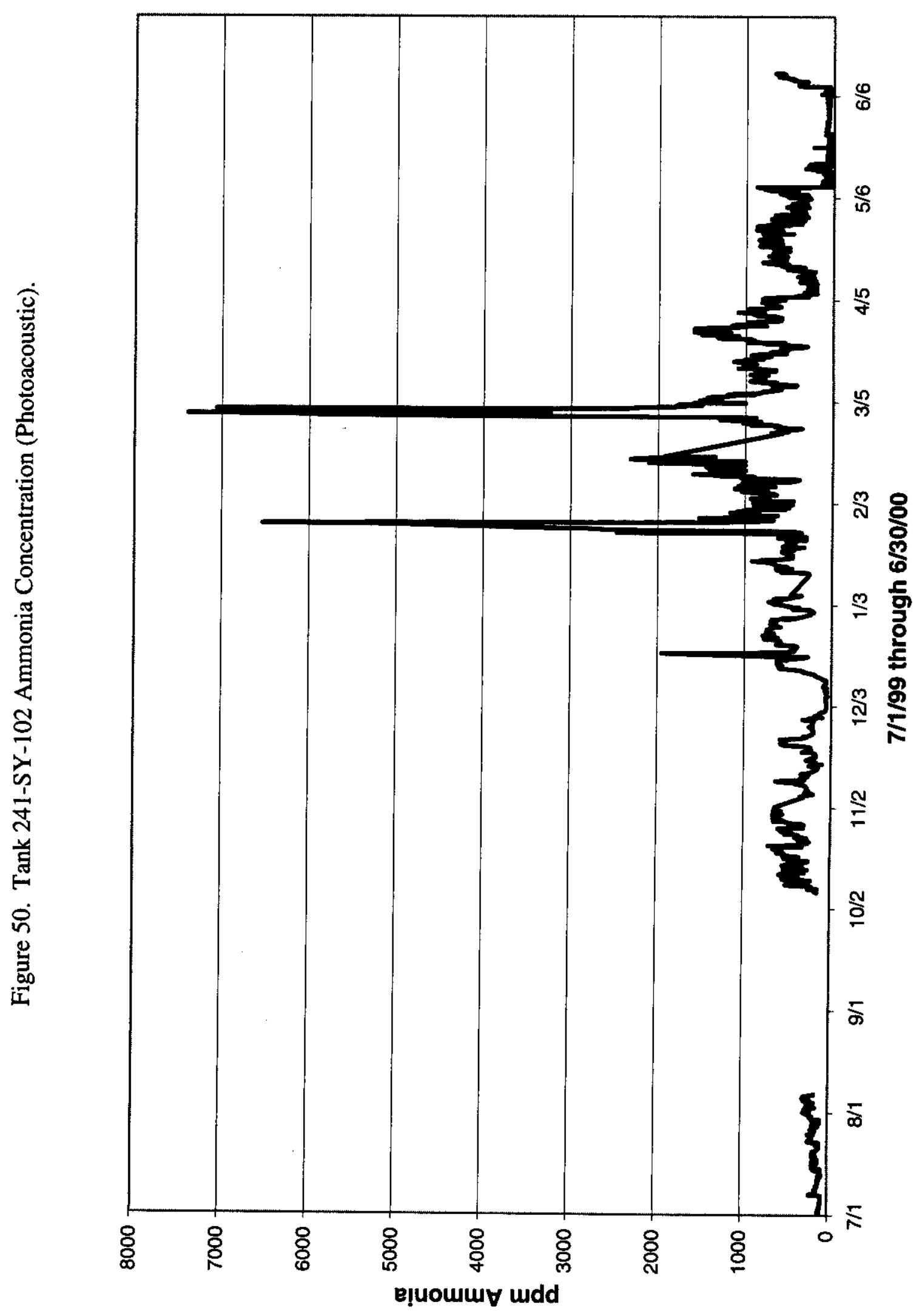




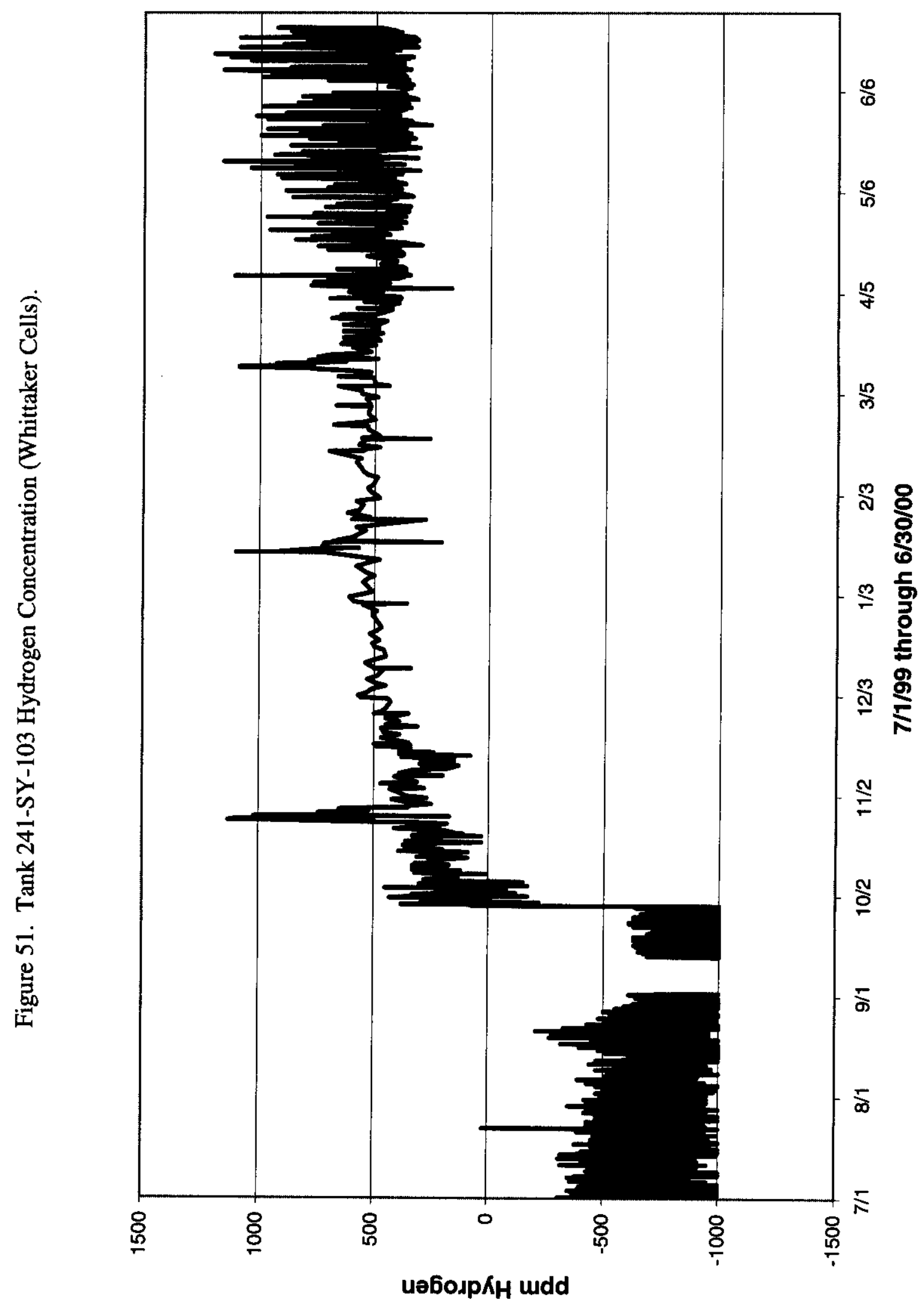


HNF-SD-WM-TI-797 REV 5

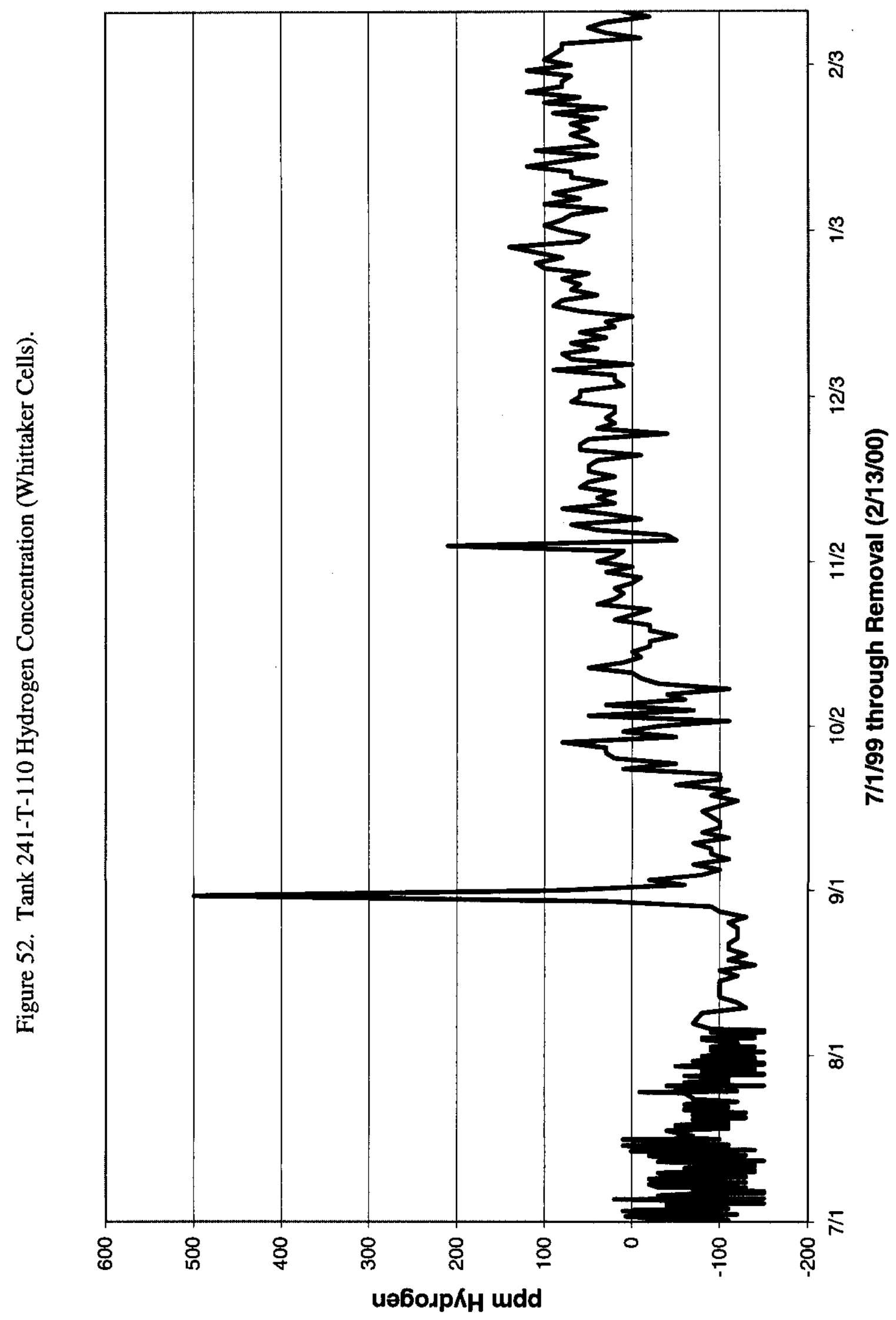




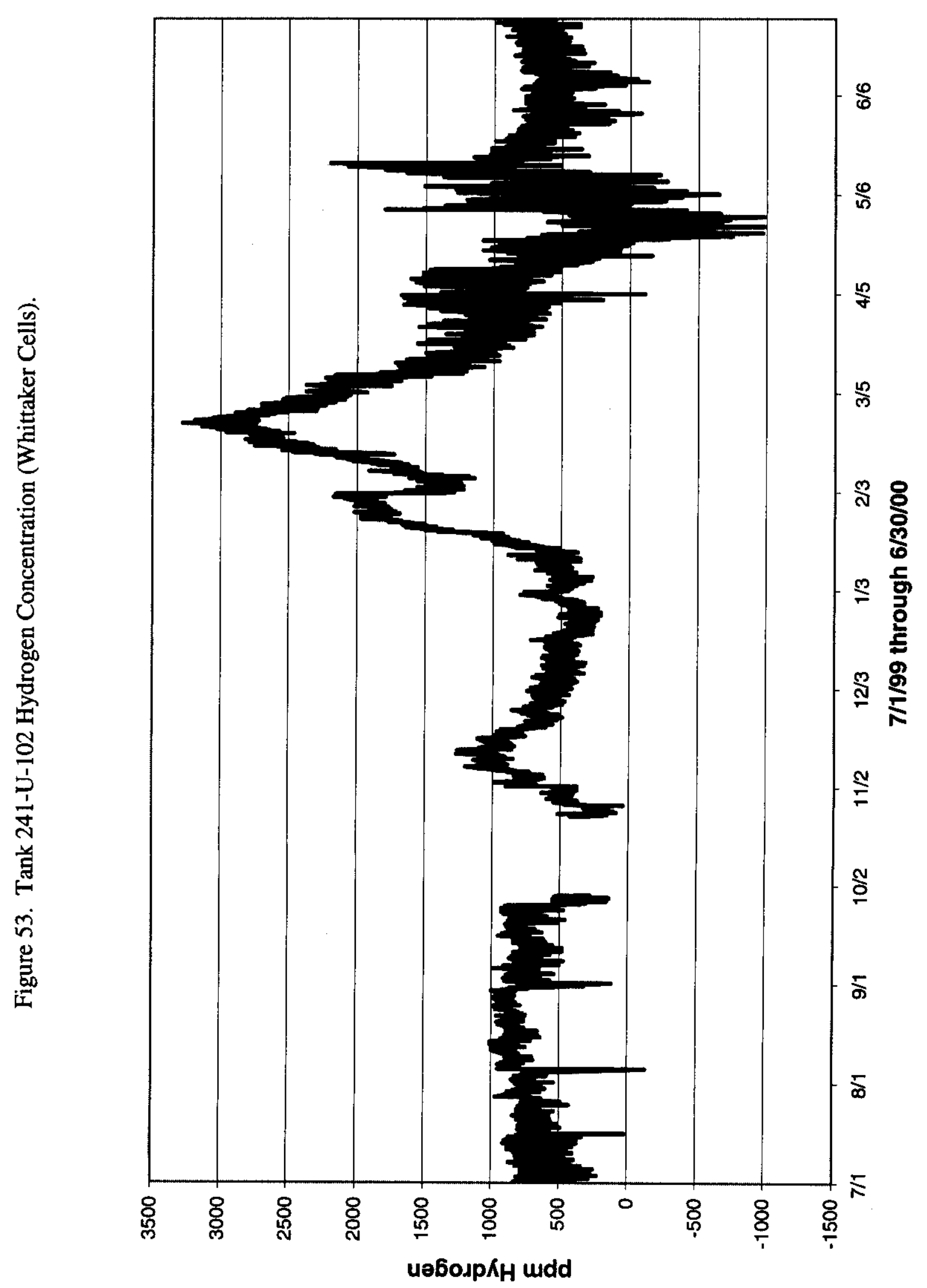




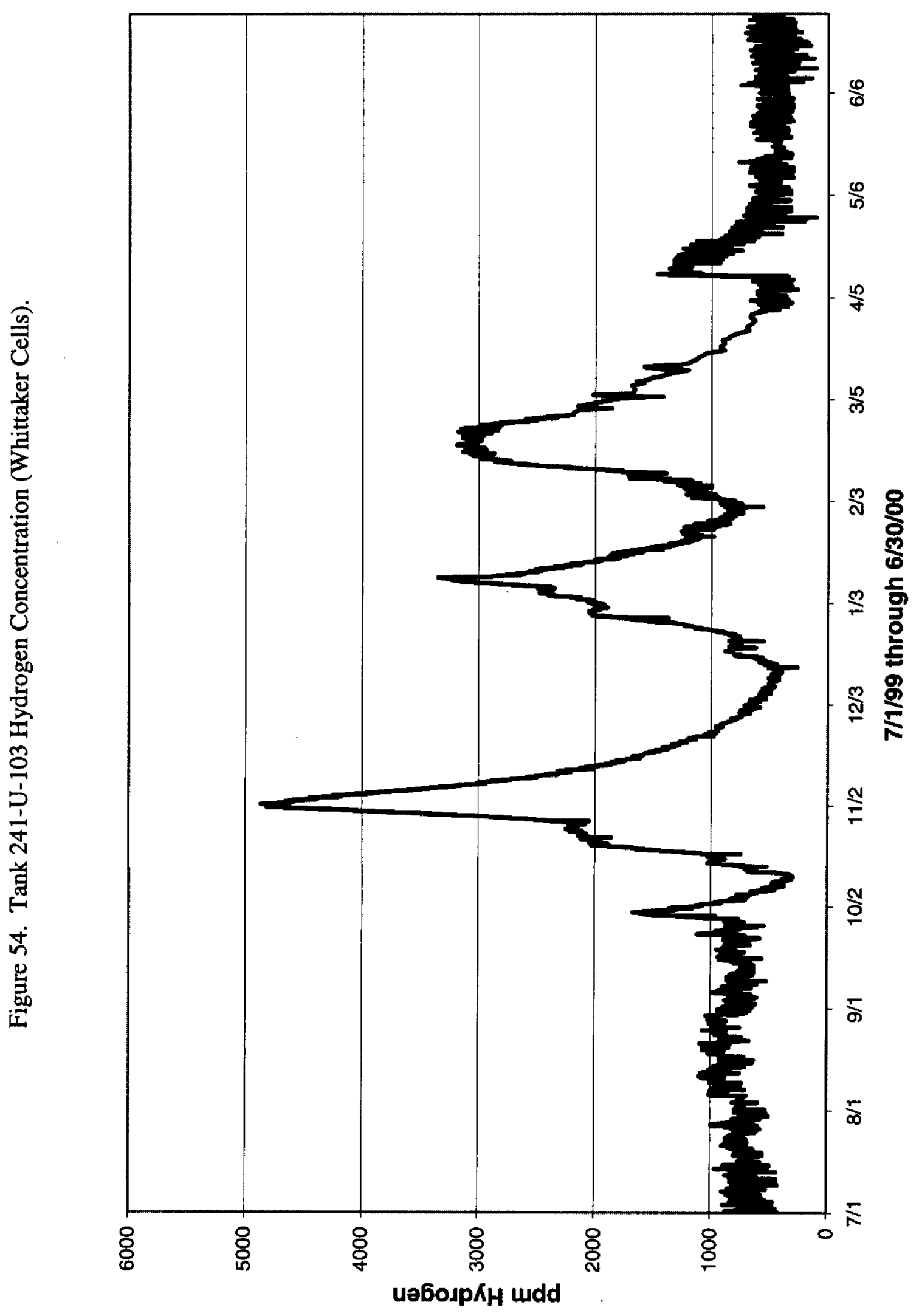




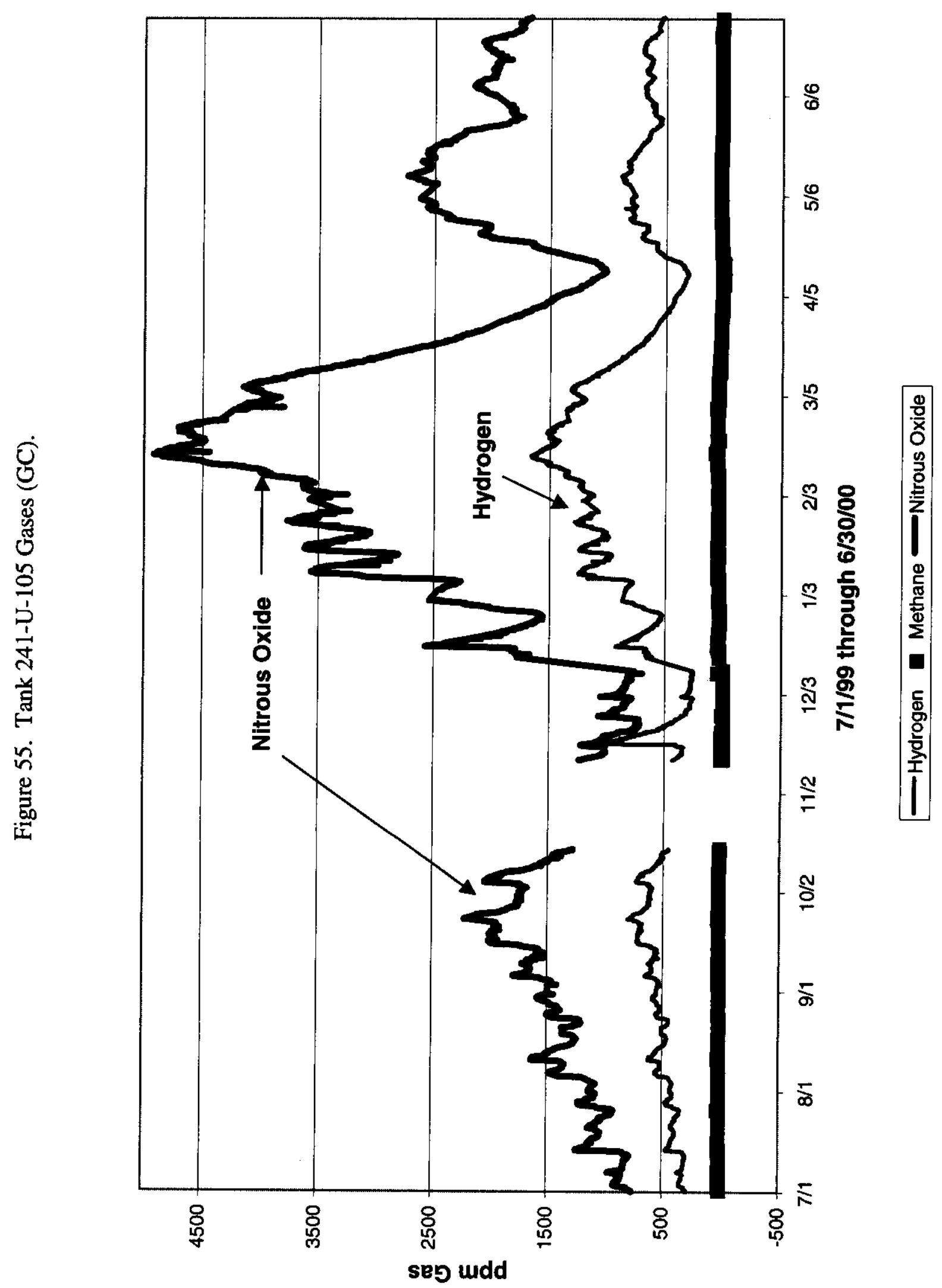




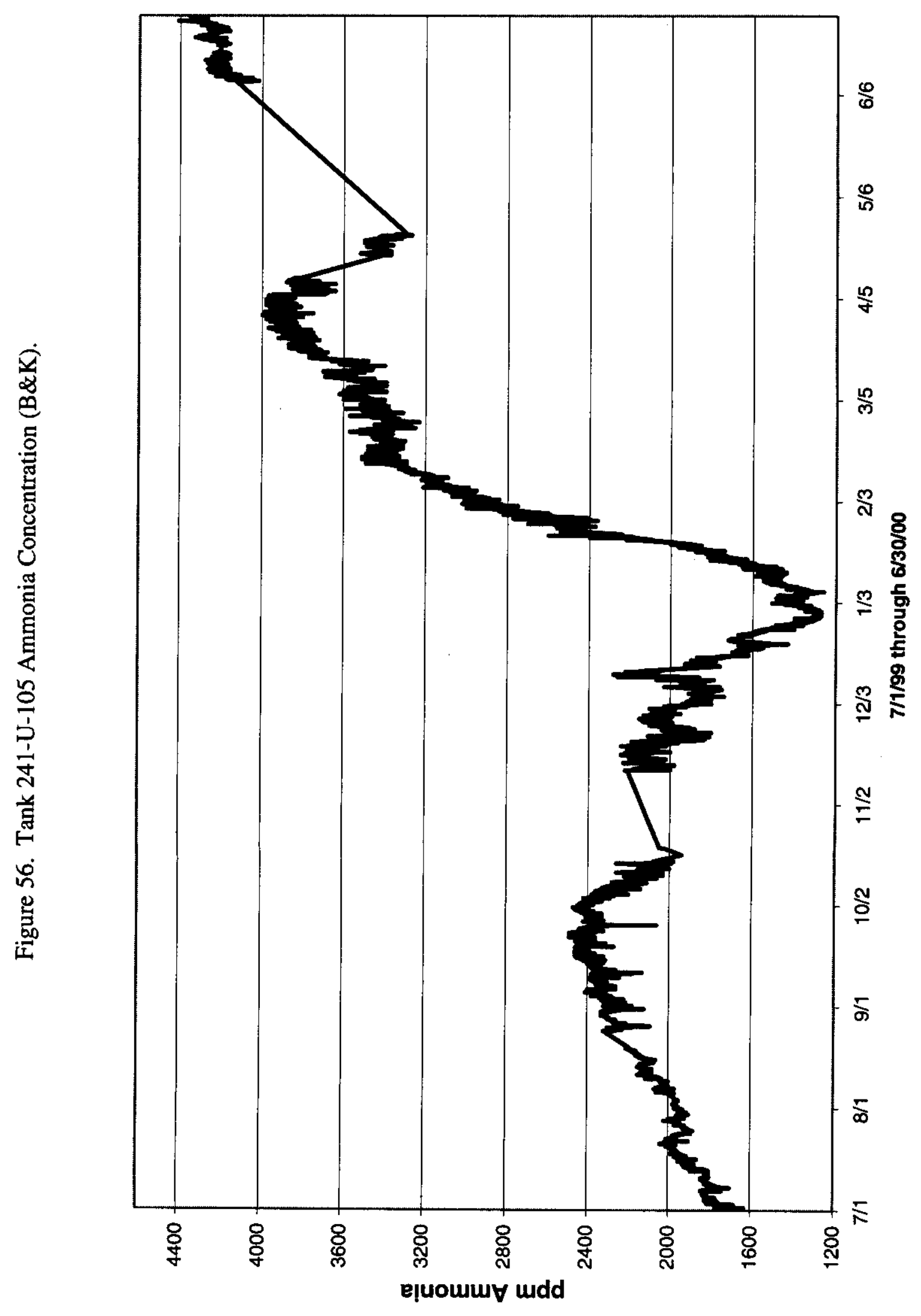




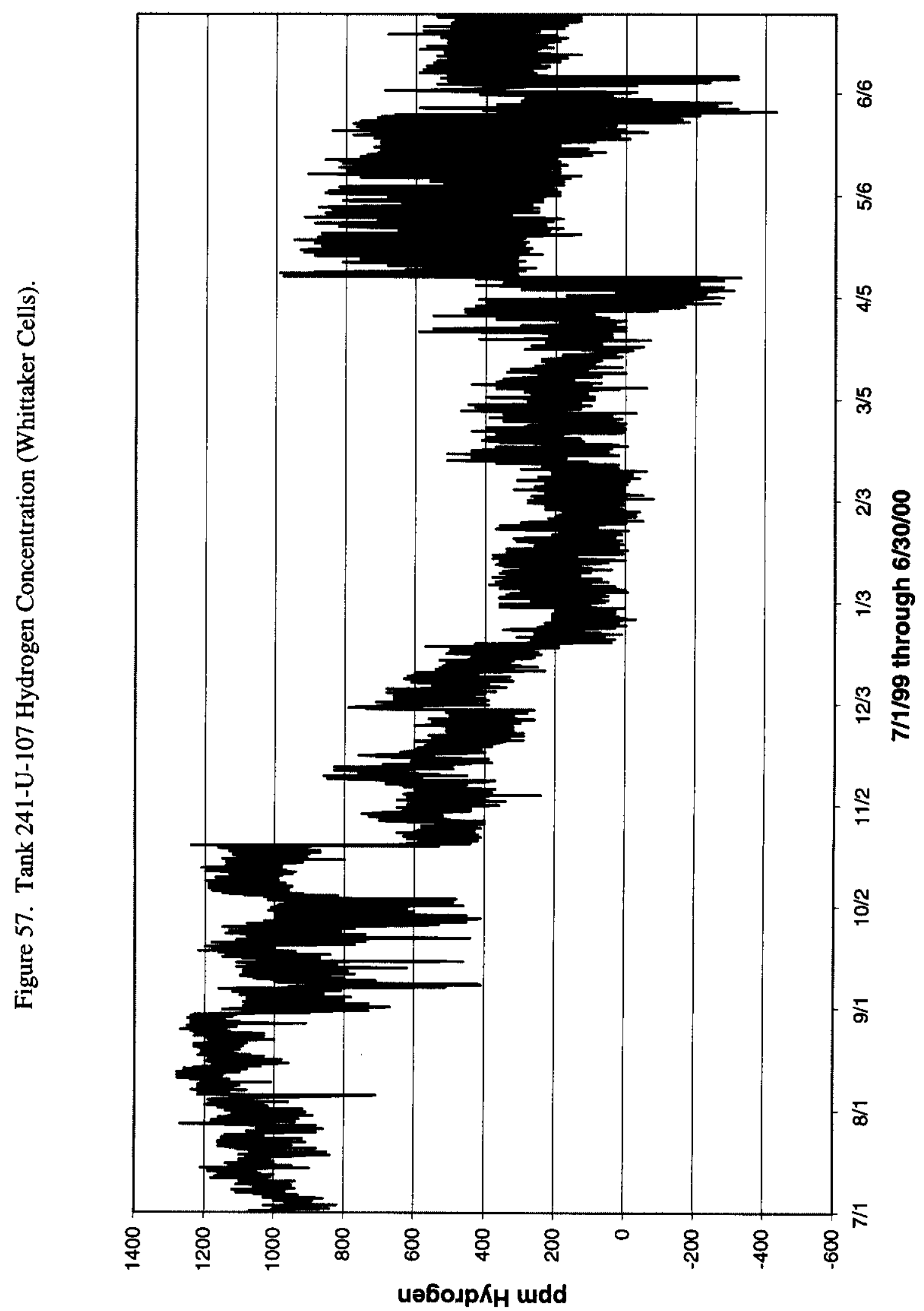


HNF-SD-WM-TI-797 REV 5

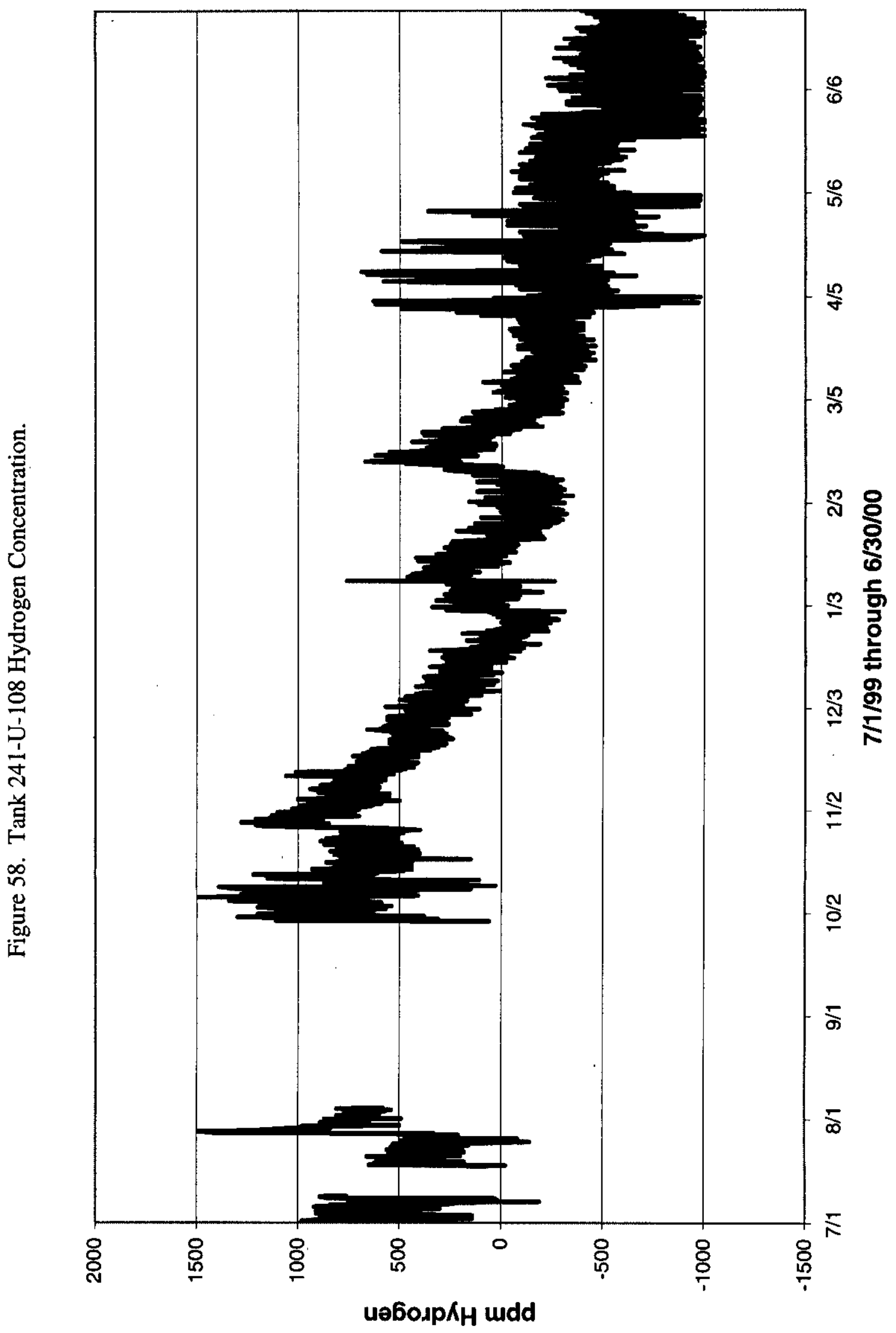


HNF-SD-WM-TI-797 REV 5

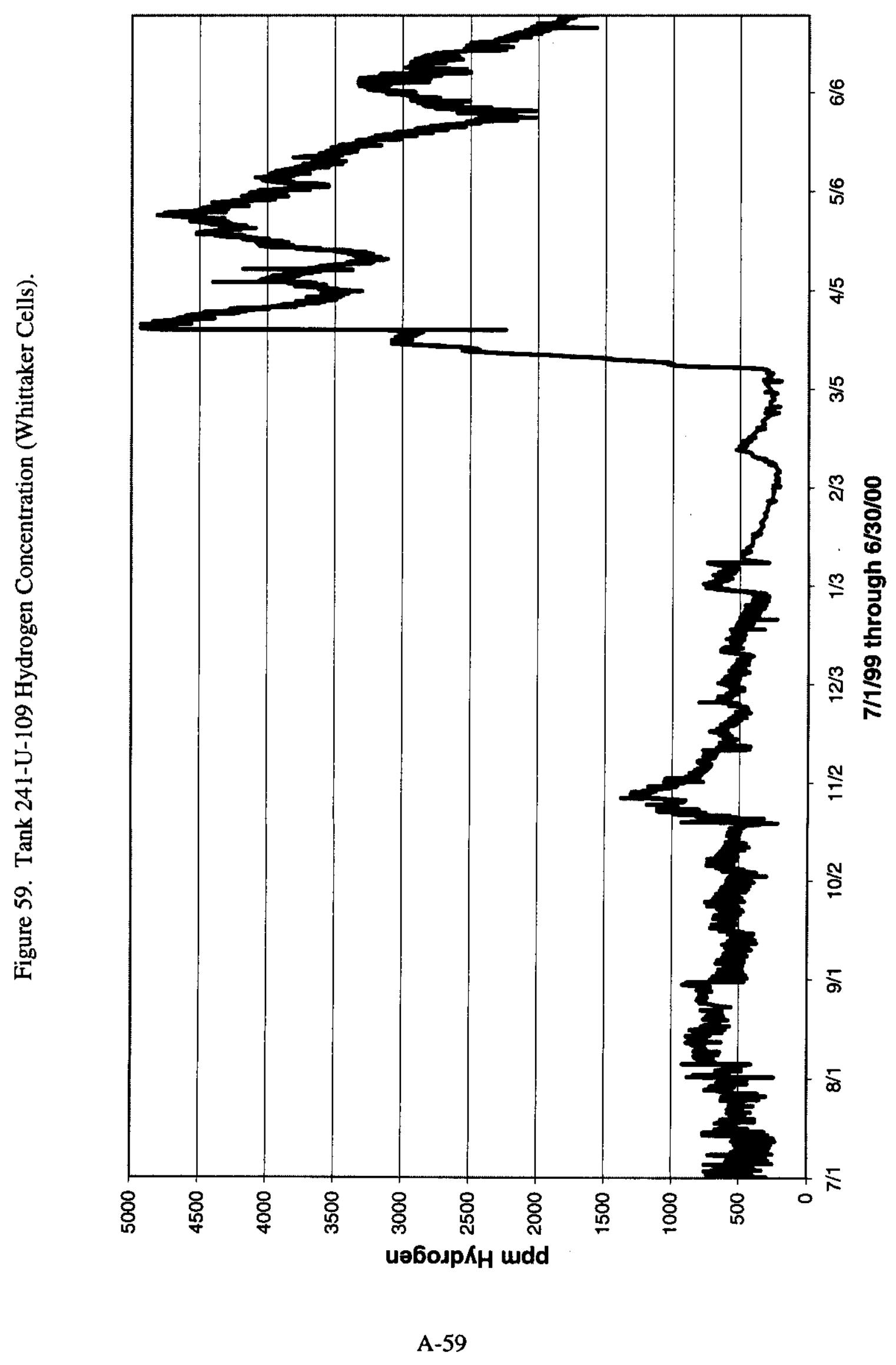




\section{HNF-SD-WM-TI-797 REV 5}

This page intentionally left blank.

A-60 
HNF-SD-WM-TI-797 REV 5

\section{APPENDIX B}

\section{VAPOR GRAB SAMPLE RESULTS (BOTH SINGLE- AND DOUBLE-SHELL TANKS)}

Note: For calculations in Appendix B, it was necessary to factor in values such as $<10 \mathrm{ppm}$. This was accomplished by establishing the nominal "less than" value as the number to be used in the calculations. Double-shell tank and stack monitor data have been placed at the end of this appendix in the format used in previous years; i.c., no averages or ratios. 
HNF-SD-WM-TI-797 REV 5

This page intentionally left blank.

B-ii 
Table B-1. Tank A-101 Vapor Grab Sample Results.

\begin{tabular}{|c|c|c|c|}
\hline Sample Date & $\begin{array}{c}\text { H2 } \\
(\mathbf{p p m})\end{array}$ & $\begin{array}{c}\text { CH4 } \\
(\mathrm{ppm})\end{array}$ & $\begin{array}{c}\mathrm{N} 20 \\
\text { (ppm) }\end{array}$ \\
\hline $5-18-95$ & 1,260 & 7 & 220 \\
\hline $6-8-95$ & 743 & $<12$ & 217 \\
\hline $6-8-95$ & 746 & $<12$ & 219 \\
\hline $6-8-95$ & 786 & $<12$ & 218 \\
\hline $7-25-95$ & 1,180 & 8 & 210 \\
\hline $7-27-95$ & 1,460 & 8 & 210 \\
\hline $8-3-95$ & 360 & 6 & 55 \\
\hline $8-4-95$ & 390 & 5 & 53 \\
\hline $8-7-95$ & 1,540 & 14 & 250 \\
\hline $8-8-95$ & 1,370 & 13 & 220 \\
\hline $8-10-95$ & 1,350 & 13 & 230 \\
\hline $8-11-95$ & 1,420 & 12 & 230 \\
\hline $8-15-95$ & 950 & 10 & 160 \\
\hline $3-19-98$ & 250 & 5 & 110 \\
\hline $5-18-98$ & 190 & 6 & 75 \\
\hline $8-21-98$ & 330 & $<10$ & 150 \\
\hline \multicolumn{4}{|c|}{$190-1,540 \mathrm{ppm}$} \\
\hline$\left[\mathbf{H}_{2}\right]_{\text {Average }}$ & \multicolumn{3}{|c|}{$895 \mathrm{ppm}$} \\
\hline$\left[\mathrm{H}_{2}\right] /\left[\mathrm{N}_{2} \mathrm{O}\right]_{\text {Range }}$ & \multicolumn{3}{|c|}{$2-7$} \\
\hline
\end{tabular}


Table B-2. Tank A-101 SUMMA ${ }^{\mathrm{TM}}$ Canister Samples.

\begin{tabular}{|l|c|c|c|c|}
\hline $\begin{array}{c}\text { Sample } \\
\text { Identification }\end{array}$ & $\begin{array}{c}\text { Hydrogen } \\
(\mathbf{p p m})\end{array}$ & $\begin{array}{c}\text { Methane } \\
(\mathbf{p p m})\end{array}$ & $\begin{array}{c}\text { Nitrous Oxide } \\
(\mathbf{p p m})\end{array}$ & $\begin{array}{c}\text { Helium } \\
(\mathbf{p p m})\end{array}$ \\
\hline V0001-A01.011 & 170 & 3 & 69 & 4 \\
\hline V0001-A02.057 & 170 & 3 & 66 & 4 \\
\hline V0001-B01.149 & 190 & 3 & 64 & 580 \\
\hline V0001-B02.223 & 190 & 3 & 74 & 580 \\
\hline V0001-C01.069 & 160 & 2 & 74 & 72 \\
\hline V0001-C02.071 & 180 & $<2$ & 73 & 79 \\
\hline
\end{tabular}

These six samples were taken on July 29,1997 , during ventilation rate measurements using helium as a tracer gas. The valves on canisters 011 and 069 were found to be leaking slightly. 
Table B-3. Tank AX-101 Vapor Grab Sample Results.

\begin{tabular}{|c|c|c|c|}
\hline Sample Date & $\begin{array}{c}\mathbf{H}_{2} \\
(\mathbf{p p m})\end{array}$ & $\begin{array}{c}\mathrm{CH}_{4} \\
(\mathrm{ppm})\end{array}$ & $\begin{array}{c}\mathrm{N}_{2} \mathrm{O} \\
\text { (ppm) }\end{array}$ \\
\hline $6-15-95$ & 103 & $<12$ & $<13$ \\
\hline $6-15-95$ & 102 & $<12$ & $<13$ \\
\hline $7-25-95$ & 59 & 2 & 6 \\
\hline $7-27-95$ & 67 & 2 & 8 \\
\hline $7-28-95$ & 50 & 1 & 5 \\
\hline $7-31-95$ & 43 & 2 & 5 \\
\hline $8-3-95$ & 57 & 2 & 6 \\
\hline $8-7-95$ & 17 & 2 & 13 \\
\hline $8-8-95$ & 56 & 2 & 5 \\
\hline $8-9-95$ & 44 & 2 & 5 \\
\hline $8-10-95$ & 100 & 3 & 9 \\
\hline $8-11-95$ & 62 & 3 & 8 \\
\hline $8-15-95$ & 78 & 2 & 7 \\
\hline $10-3-96$ & 65 & $<10$ & $<10$ \\
\hline $10-3-96$ & 63 & $<10$ & $<10$ \\
\hline $12-19-96$ & 28 & $<10$ & $<10$ \\
\hline $12-19-96$ & 40 & $<10$ & $<10$ \\
\hline 1-29-97 & 18 & $<10$ & $<10$ \\
\hline $3-12-97$ & 26 & $<10$ & $<10$ \\
\hline $3-12-97$ & 18 & $<10$ & $<10$ \\
\hline $2-12-99$ & 18 & $<10$ & $<10$ \\
\hline \multicolumn{4}{|c|}{$17-103$ ppm } \\
\hline$\left[\mathrm{H}_{2}\right]_{\text {Average }}$ & \multicolumn{3}{|c|}{$53 \mathrm{ppm}$} \\
\hline$\left[\mathrm{H}_{2}\right] /\left[\mathrm{N}_{2} \mathrm{O}\right]_{\text {Range }}$ & \multicolumn{3}{|c|}{$1-11$} \\
\hline
\end{tabular}


Table B-4. Tank AX-103 Vapor Grab Sample Results.

\begin{tabular}{|c|c|c|c|}
\hline Sample Date & $\begin{array}{r}\mathbf{H}_{2} \\
(\mathbf{p p m})\end{array}$ & $\begin{array}{c}\mathrm{CH}_{4} \\
(\mathrm{ppm})\end{array}$ & $\begin{array}{l}\mathrm{N}_{2} \mathrm{O} \\
(\mathrm{ppm})\end{array}$ \\
\hline $6-21-95$ & $<98$ & $<12$ & 24 \\
\hline $6-21-95$ & $<98$ & $<12$ & 24 \\
\hline $6-21-95$ & $<98$ & $<12$ & 23 \\
\hline $7-25-95$ & 27 & 2 & 21 \\
\hline $7-27-95$ & 33 & 2 & 24 \\
\hline $7-28-95$ & 28 & 1 & 24 \\
\hline $7-31-95$ & 27 & 2 & 22 \\
\hline $8-3-95$ & 24 & 2 & 24 \\
\hline $8-4-95$ & 26 & 3 & 25 \\
\hline $8-7-95$ & 17 & 2 & 13 \\
\hline $10-3-96$ & 36 & $<10$ & 40 \\
\hline $10-3-96$ & 20 & $<10$ & 20 \\
\hline \multicolumn{4}{|c|}{$17-<98$ ppm } \\
\hline$\left[\mathrm{H}_{2}\right]_{\text {Average }}$ & \multicolumn{3}{|c|}{$26 \mathrm{ppm}$} \\
\hline$\left[\mathrm{H}_{2}\right] /\left[\mathrm{N}_{2} \mathrm{O}\right]_{\text {Range }}$ & \multicolumn{3}{|c|}{$0.9-1.4$} \\
\hline
\end{tabular}


HNF-SD-WM-TI-797 REV 5

Table B-5. Tank BY-103 Vapor Sample Results.

\begin{tabular}{|c|c|c|c|}
\hline Sample Date & $\begin{array}{c}\mathbf{H}_{2} \\
(\mathbf{p p m})\end{array}$ & $\begin{array}{c}\mathrm{CH}_{4} \\
(\mathrm{ppm})\end{array}$ & $\begin{array}{c}\mathrm{N}_{2} \mathrm{O} \\
(\mathrm{ppm})\end{array}$ \\
\hline $5-5-94$ & 21 & $\mathrm{n} / \mathrm{r}$ & 49 \\
\hline $5-5-94$ & 22 & $\mathrm{n} / \mathrm{r}$ & 49 \\
\hline $5-5-94$ & 21 & $\mathrm{n} / \mathrm{r}$ & 49 \\
\hline $9-22-95$ & 230 & 4 & 70 \\
\hline $10-2-95$ & 130 & 3 & 22 \\
\hline $10-9-95$ & 200 & 3 & 25 \\
\hline $10-13-95$ & 150 & 2 & 19 \\
\hline $3-27-96$ & 66 & $<10$ & 20 \\
\hline $3-27-96$ & 69 & $<10$ & 20 \\
\hline $8-22-97$ & 10 & 1 & 9 \\
\hline $11-19-97$ & $<10$ & 1 & $<10$ \\
\hline $2-18-98$ & $<10$ & 2 & $<10$ \\
\hline $4-24-98$ & $<10$ & 2 & 13 \\
\hline $7-15-98$ & $<10$ & $<10$ & $<10$ \\
\hline $3-23-99$ & 12 & $<50$ & 14 \\
\hline$\left[\mathrm{H}_{2}\right]_{\text {Range }}$ & \multicolumn{3}{|l|}{$<10-230$ ppm } \\
\hline$\left[\mathrm{H}_{2}\right]_{\text {Average }}$ & \multicolumn{3}{|l|}{$65 \mathrm{ppm}$} \\
\hline$\left[\mathrm{H}_{2}\right] /\left[\mathrm{N}_{2} \mathrm{O}\right]_{\text {Range }}$ & \multicolumn{3}{|l|}{$0.43-8$} \\
\hline
\end{tabular}

Note:

$$
n / r=\text { not reported }
$$


Table B-6. Tank BY-105 Vapor Sample Results.

\begin{tabular}{|l|c|c|c|}
\hline Sample Date & $\begin{array}{c}\mathbf{H}_{2} \\
(\mathbf{p p m})\end{array}$ & $\begin{array}{c}\mathbf{C H}_{\mathbf{4}} \\
(\mathbf{p p m})\end{array}$ & $\begin{array}{c}\mathbf{N}_{\mathbf{2}} \mathbf{O} \\
(\mathbf{p p m})\end{array}$ \\
\hline $6-11-98$ & 55 & $<10$ & 65 \\
\hline $9-14-98$ & 20 & $<10$ & 20 \\
\hline$\left[\mathbf{H}_{2}\right]_{\text {Range }}$ & $\mathbf{5 5}-\mathbf{2 0} \mathbf{~ p p m}$ & \\
\hline$\left[\mathbf{H}_{2}\right]_{\text {Average }}$ & $\mathbf{3 8} \mathbf{~ p p m}$ & & \\
\hline$\left[\mathbf{H}_{2}\right] /\left[\mathbf{N}_{2} \mathbf{O}\right]_{\text {Range }}$ & $\mathbf{8 5}-\mathbf{1 . 0 0}$ & \\
\hline
\end{tabular}


Table B-7. Tank BY-106 Vapor Sample Results.

\begin{tabular}{|c|c|c|c|}
\hline Sample Date & $\begin{array}{c}\mathbf{H}_{2} \\
(\mathbf{p p m})\end{array}$ & $\begin{array}{c}\mathrm{CH}_{4} \\
(\mathbf{p p m})\end{array}$ & $\begin{array}{c}\mathrm{N}_{2} \mathrm{O} \\
\text { (ppm) }\end{array}$ \\
\hline $5-4-94$ & 48 & $<61$ & 92 \\
\hline $5-4-94$ & 43 & $<61$ & 91 \\
\hline $5-4-94$ & 46 & $<61$ & 96 \\
\hline $7-8-94$ & 104 & 3.6 & 70 \\
\hline 7-8-94 & 47 & 4 & 71 \\
\hline $7-8-94$ & 40 & 4 & 71 \\
\hline $9-22-95$ & 1,110 & 20 & 1,140 \\
\hline $10-2-95$ & 520 & 12 & 410 \\
\hline 10-9-95 & 210 & 5 & 17 \\
\hline $10-13-95$ & 140 & 2 & 45 \\
\hline $3-27-96$ & 51 & $<10$ & 41 \\
\hline $3-27-96$ & 50 & $<10$ & 34 \\
\hline $8-22-97$ & 43 & 2 & 32 \\
\hline $11-19-97$ & 50 & 1 & 36 \\
\hline $2-18-98$ & 40 & 5 & 160 \\
\hline 4-24-98 & 50 & 2 & 70 \\
\hline $7-15-98$ & 40 & $<10$ & 40 \\
\hline $3-23-99$ & 58 & $<50$ & 70 \\
\hline$\left[\mathrm{H}_{2}\right]_{\text {Range }}$ & \multicolumn{3}{|c|}{40 - 1,110 ppm } \\
\hline$\left[\mathbf{H}_{2}\right]_{\text {Average }}$ & \multicolumn{3}{|c|}{149 ppm } \\
\hline$\left[\mathrm{H}_{2}\right] /\left[\mathrm{N}_{2} \mathrm{O}\right]_{\text {Range }}$ & \multicolumn{3}{|c|}{$0.25-12$} \\
\hline
\end{tabular}


Table B-8. Tank BY-109 Vapor Sample Results.

\begin{tabular}{|c|c|c|c|}
\hline Sample Date & $\begin{array}{c}\mathbf{H}_{2} \\
(\mathbf{p p m})\end{array}$ & $\begin{array}{c}\mathrm{CH}_{4} \\
(\mathrm{ppm})\end{array}$ & $\begin{array}{c}\mathrm{N}_{2} \mathrm{O} \\
\text { (ppm) }\end{array}$ \\
\hline $9-22-95$ & 154 & 2 & 40 \\
\hline $10-2-95$ & 90 & 4 & 9 \\
\hline $10-9-95$ & 100 & 4 & 7 \\
\hline $10-13-95$ & 80 & 2 & 6 \\
\hline $3-27-96$ & 10 & $<10$ & $<5$ \\
\hline $3-27-96$ & 15 & $<10$ & $<5$ \\
\hline 8-22-97 & 39 & 3 & $<10$ \\
\hline 11-19-97 & 10 & $<5$ & $<10$ \\
\hline $2-18-98$ & 11 & 1 & $<10$ \\
\hline 4-24-98 & 12 & 1 & $<10$ \\
\hline $7-15-98$ & 22 & $<10$ & $<10$ \\
\hline $10-26-98$ & $<10$ & $<10$ & $<10$ \\
\hline$\left[\mathbf{H}_{2}\right]_{\text {Range }}$ & \multicolumn{3}{|l|}{$<10-154 \mathrm{ppm}$} \\
\hline$\left[\mathbf{H}_{2}\right]_{\text {Average }}$ & \multicolumn{3}{|l|}{$46 \mathrm{ppm}$} \\
\hline$\left[\mathrm{H}_{2}\right] /\left[\mathrm{N}_{2} \mathrm{O}\right]_{\text {Range }}$ & \multicolumn{3}{|c|}{$2-14$ (division by $<10$ is undefined) } \\
\hline
\end{tabular}


Table B-9. Tank C-106 Vapor Sample Results.

\begin{tabular}{|c|c|c|c|}
\hline Sample Date & $\begin{array}{c}\mathbf{H}_{2} \\
(\mathbf{p p m})\end{array}$ & $\begin{array}{c}\mathrm{CH}_{4} \\
(\mathbf{p p m})\end{array}$ & $\begin{array}{c}\mathrm{N}_{2} \mathrm{O} \\
(\mathbf{p p m})\end{array}$ \\
\hline $3-17-97$ & 4 & 4 & $<10$ \\
\hline 3-17-97 & 4.4 & 5 & $<10$ \\
\hline $3-18-97$ & 5 & 4 & $<10$ \\
\hline $3-18-97$ & 4.2 & 4 & $<10$ \\
\hline $3-19-97$ & 5 & 5 & $<10$ \\
\hline $3-19-97$ & 4.4 & 5 & $<10$ \\
\hline $3-20-97$ & 6.5 & 4 & $<10$ \\
\hline $3-20-97$ & 1.8 & 5 & $<10$ \\
\hline $3-21-97$ & 8.7 & 5 & $<10$ \\
\hline 3-21-97 & 6.6 & 4 & $<10$ \\
\hline 3-27-97 & 5.8 & 3 & $<10$ \\
\hline $3-27-97$ & 4.5 & 4 & $<10$ \\
\hline 6-4-97(1445) & 4.2 & 2 & $<10$ \\
\hline $6-4-97(1445)$ & 4.3 & 2 & $<10$ \\
\hline $6-4-97(2146)$ & 22 & 1 & 11 \\
\hline $6-4-97(2146)$ & 20 & 1 & 11 \\
\hline $6-5-97(0509)$ & 38 & 1 & 18 \\
\hline $6-5-97(0509)$ & 38 & 2 & 20 \\
\hline $6-5-97(1440)$ & 69 & 2 & 32 \\
\hline $6-5-97(1440)$ & 67 & 2 & 31 \\
\hline $6-5-97(2152)$ & 68 & 2 & 32 \\
\hline $6-5-97(2152)$ & 14 & 2 & 8 \\
\hline 6-6-97 (0530) & 100 & 2 & 55 \\
\hline $6-6-97(0530)$ & 49 & 2 & 25 \\
\hline $6-9-98(1140)$ & $<10$ & $<10$ & $<10$ \\
\hline \multicolumn{4}{|c|}{$1.8-100 \mathrm{ppm}$} \\
\hline$\left[\mathrm{H}_{2}\right]_{\text {Average }}$ & \multicolumn{3}{|c|}{$23 \mathrm{ppm}$} \\
\hline$\left[\mathrm{H}_{2}\right] /\left[\mathrm{N}_{2} \mathrm{O}\right]_{\text {Range }}$ & \multicolumn{3}{|c|}{$1.8-2.2$} \\
\hline
\end{tabular}


Table B-10. Tank S-101 Vapor Sample Results.

\begin{tabular}{|c|c|c|c|}
\hline Sample Date & $\begin{array}{c}\mathbf{H}_{2} \\
(\mathbf{p p m})\end{array}$ & $\begin{array}{l}\mathbf{C H}_{4} \\
(\mathbf{p p m})\end{array}$ & $\begin{array}{c}\mathrm{N}_{2} \mathrm{O} \\
\text { (ppm) }\end{array}$ \\
\hline $6-5-98$ & 425 & $<10$ & 275 \\
\hline $9-14-98$ & 280 & $<10$ & 75 \\
\hline $12-7-98$ & 425 & $<10$ & 240 \\
\hline$\left[\mathrm{H}_{2}\right]_{\text {Range }}$ & \multicolumn{3}{|l|}{$280-425$ ppm } \\
\hline$\left[\mathbf{H}_{2}\right]_{\text {Average }}$ & \multicolumn{3}{|l|}{377 ppm } \\
\hline$\left[\mathrm{H}_{2}\right] /\left[\mathrm{N}_{2} \mathrm{O}\right]_{\text {Range }}$ & \multicolumn{3}{|l|}{$1.5-1.8$} \\
\hline
\end{tabular}

Table B-11. Tank S-102 Vapor Sample Results.

\begin{tabular}{|c|c|c|c|}
\hline Sample Date & $\begin{array}{c}\text { H2 } \\
(\mathbf{p p m})\end{array}$ & $\begin{array}{c}\text { CH4 } \\
(\mathbf{p p m})\end{array}$ & $\begin{array}{c}\text { N2O } \\
\mathbf{p p m})\end{array}$ \\
\hline $3-14-95$ & 669 & $<12$ & 491 \\
\hline $3-14-95$ & 670 & $<12$ & 550 \\
\hline $3-14-95$ & 668 & $<12$ & 487 \\
\hline $5-5-95$ & 300 & 4 & 210 \\
\hline $8-4-95$ & 600 & 4 & 410 \\
\hline $8-7-95$ & 280 & 4 & 210 \\
\hline $8-7-95$ & 410 & 5 & 280 \\
\hline $8-8-95$ & 750 & 7 & 560 \\
\hline $8-8-95$ & 720 & 8 & 510 \\
\hline $8-9-95$ & 700 & 9 & 490 \\
\hline $8-10-95$ & 750 & 10 & 530 \\
\hline $8-10-95$ & 760 & 9 & 540 \\
\hline $8-11-95$ & 750 & 10 & 530 \\
\hline $1-21-99$ & 400 & 17 & 440 \\
\hline$\left[\mathbf{H}_{\mathbf{2}}\right]_{\mathbf{2}}$ & $\left.\mathbf{2} \mathbf{N}_{\mathbf{2}} \mathbf{O}\right]_{\text {Range }}$ & $\mathbf{0 . 9 1 - 1 . 5}$ & \\
\hline
\end{tabular}


Table B-12. Tank S-106 Vapor Sample Results.

\begin{tabular}{|c|c|c|c|}
\hline Sample Date & $\begin{array}{c}\mathbf{H}_{\mathbf{2}} \\
\mathbf{( p p m )}\end{array}$ & $\begin{array}{c}\mathbf{C H}_{\mathbf{4}} \\
(\mathbf{p p m})\end{array}$ & $\begin{array}{c}\mathbf{N}_{\mathbf{2}} \mathbf{O} \\
(\mathbf{p p m})\end{array}$ \\
\hline $6-5-98$ & 20 & $<10$ & $<10$ \\
\hline $9-14-98$ & 30 & $<10$ & $<10$ \\
\hline $11-12-98$ & 14 & $<10$ & $<10$ \\
\hline$\left[\mathbf{H}_{\mathbf{2}}\right]_{\text {Range }}$ & $\mathbf{1 4 - 3 0} \mathbf{~ p p m}$ & \\
\hline$\left[\mathbf{H}_{\mathbf{2}}\right]_{\text {Average }}$ & $\mathbf{2 1 ~ p p m}$ & & \\
\hline$\left[\mathbf{H}_{\mathbf{2}}\right] /\left[\mathbf{N}_{\mathbf{2}} \mathbf{O}\right]_{\text {Range }}$ & Undetermined & \\
\hline
\end{tabular}

Table B-13. Tank S-107 Vapor Sample Results.

\begin{tabular}{|c|c|c|c|}
\hline Sample Date & $\begin{array}{c}\mathbf{H}_{\mathbf{2}} \\
(\mathbf{p p m})\end{array}$ & $\begin{array}{c}\mathbf{C H} \\
(\mathbf{p p m})\end{array}$ & $\begin{array}{c}\mathbf{N}_{\mathbf{2}} \mathbf{O} \\
(\mathbf{p p m})\end{array}$ \\
\hline $6-5-98$ & 180 & $<10$ & 90 \\
\hline $9-14-98$ & 165 & $<10$ & 80 \\
\hline $12-7-98$ & 150 & $<10$ & 65 \\
\hline$\left[\mathbf{H}_{2}\right]_{\text {Range }}$ & $\mathbf{1 5 0 - \mathbf { 1 8 0 }} \mathbf{~ p p m}$ & & \\
\hline$\left[\mathbf{H}_{\mathbf{2}}\right]_{\text {Average }}$ & $\mathbf{1 6 5} \mathbf{~ p p m}$ & & \\
\hline$\left[\mathbf{H}_{\mathbf{2}}\right] /\left[\mathbf{N}_{\mathbf{2}} \mathbf{O}\right]_{\text {Range }}$ & $\mathbf{2 . 0} \mathbf{2 . 3}$ & \\
\hline
\end{tabular}

Table B-14. Tank S-109 Vapor Sample Results.

\begin{tabular}{|c|c|c|c|}
\hline \multicolumn{1}{|c|}{ Sample Date } & $\begin{array}{c}\mathbf{H}_{2} \\
(\mathbf{p p m})\end{array}$ & $\begin{array}{c}\mathbf{C H}_{\mathbf{4}} \\
(\mathbf{p p m})\end{array}$ & $\begin{array}{c}\mathbf{N}_{\mathbf{2}} \mathbf{O} \\
(\mathbf{p p m})\end{array}$ \\
\hline $6-5-98$ & 27 & $<10$ & $<10$ \\
\hline $9-14-98$ & 62 & $<10$ & $<10$ \\
\hline$\left[\mathbf{H}_{2}\right]_{\text {Range }}$ & $\mathbf{2 7 - 6 2} \mathbf{~ p p m}$ & & \\
\hline$\left[\mathbf{H}_{\mathbf{2}}\right]_{\text {Average }}$ & $\mathbf{4 5} \mathbf{~ p p m}$ & & \\
\hline$\left.\left[\mathbf{H}_{\mathbf{2}}\right]_{[} \mathbf{N}_{\mathbf{2}} \mathbf{O}\right]_{\text {Range }}$ & Undetermined & \\
\hline
\end{tabular}


Table B-15. Tank S-111 Vapor Sample Results.

\begin{tabular}{|c|c|c|c|}
\hline Sample Date & $\begin{array}{c}\mathbf{H}_{2} \\
(\mathbf{p p m})\end{array}$ & $\begin{array}{c}\mathrm{CH}_{4} \\
\text { (ppm) }\end{array}$ & $\begin{array}{l}\mathrm{N}_{2} \mathrm{O} \\
(\mathrm{ppm})\end{array}$ \\
\hline $7-11-95$ & 53 & $<5$ & $<10$ \\
\hline $7-14-95$ & 16 & $<5$ & $<10$ \\
\hline $7-17-95$ & $<5$ & $<5$ & $<10$ \\
\hline $8-3-95$ & 77 & 2 & 17 \\
\hline $8-4-95$ & 5 & 2 & $<5$ \\
\hline $8-7-95$ & 210 & 3 & 38 \\
\hline $8-29-97$ & 280 & 2 & 26 \\
\hline $10-22-97$ & 280 & 5 & 22 \\
\hline $1-23-98$ & 91 & 3 & 19 \\
\hline 4-17-98 & 80 & 2 & 18 \\
\hline $8-19-98$ & 60 & $<10$ & 20 \\
\hline $12-7-98$ & 25 & $<10$ & $<50$ \\
\hline$\left[\mathrm{H}_{2}\right]_{\text {Range }}$ & \multicolumn{3}{|l|}{$<5-210 \mathrm{ppm}$} \\
\hline$\left[\mathrm{H}_{2}\right]_{\text {Average }}$ & \multicolumn{3}{|l|}{99 ppm } \\
\hline$\left[\mathrm{H}_{2}\right] /\left[\mathrm{N}_{2} \mathrm{O}\right]_{\text {Range }}$ & \multicolumn{3}{|l|}{$0.5-13$} \\
\hline
\end{tabular}


Table B-16. Tank S-112 Vapor Sample Results.

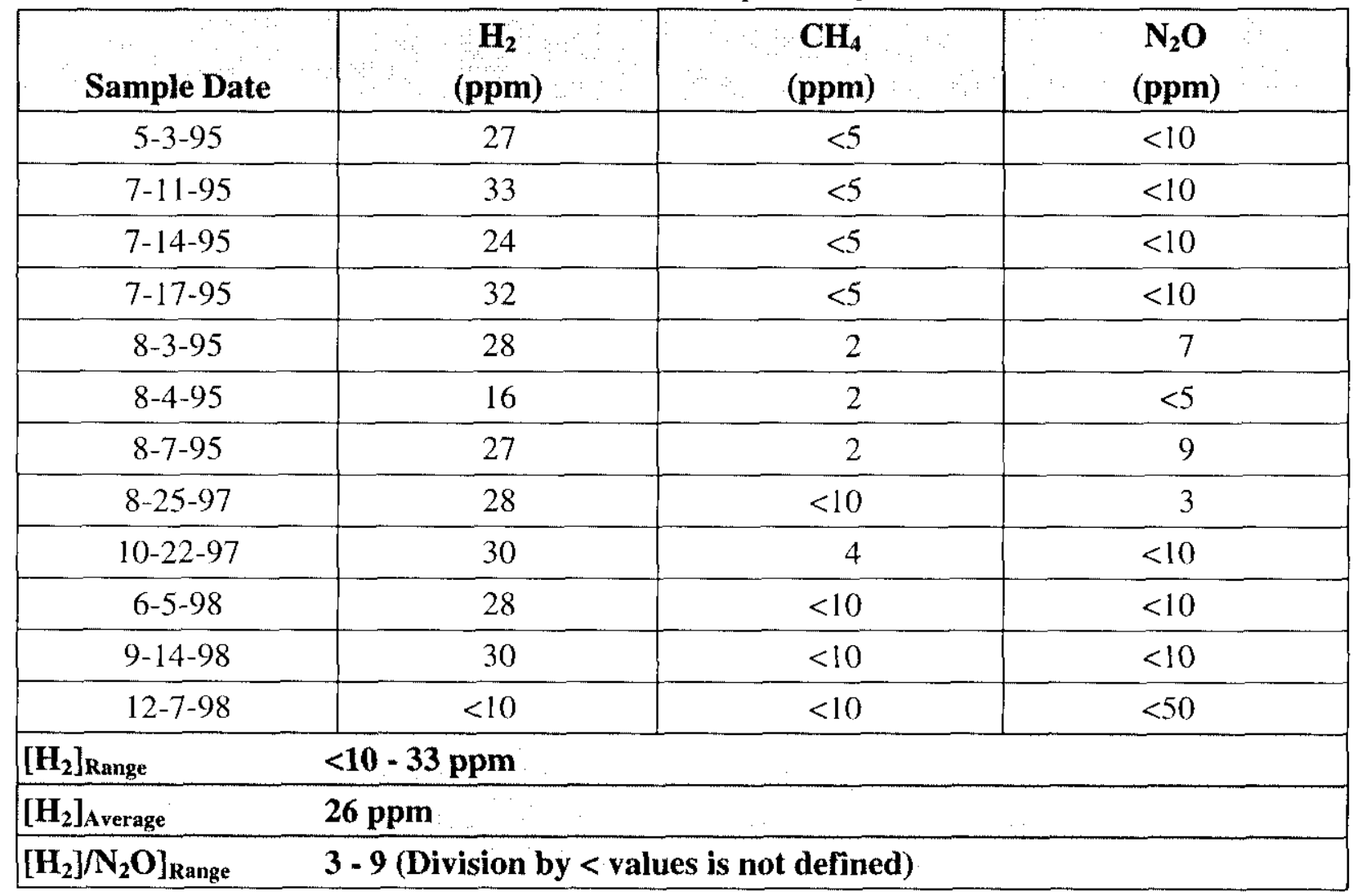


HNF-SD-WM-TI-797 REV 5

Table B-17. Tank SX-101 Vapor Sample Results.

\begin{tabular}{|c|c|c|c|}
\hline Sample Date & $\begin{array}{c}\mathbf{H}_{2} \\
(\mathbf{p p m})\end{array}$ & $\begin{array}{c}\mathrm{CH}_{4} \\
(\mathrm{ppm})\end{array}$ & $\begin{array}{c}\mathrm{N}_{2} \mathrm{O} \\
(\mathrm{ppm})\end{array}$ \\
\hline $6-2-95$ & 8 & 2 & $<5$ \\
\hline $6-6-95$ & 5 & $<5$ & $<5$ \\
\hline $6-9-95$ & $<5$ & 2 & $<5$ \\
\hline $6-22-95$ & 7 & $<5$ & $<5$ \\
\hline $6-27-95$ & $<5$ & $<5$ & $<5$ \\
\hline $6-30-95$ & $<5$ & $<10$ & $<5$ \\
\hline $7-7-95$ & $<5$ & $<10$ & $<5$ \\
\hline $9-11-95$ & $<5$ & 2 & $<5$ \\
\hline $9-15-95$ & $\mathrm{n} / \mathrm{r}$ & $\mathrm{n} / \mathrm{r}$ & $\mathrm{n} / \mathrm{r}$ \\
\hline $9-19-95$ & $\mathrm{n} / \mathrm{r}$ & 2 & $\mathrm{n} / \mathrm{r}$ \\
\hline $9-25-95$ & 10 & 2 & $\mathrm{n} / \mathrm{r}$ \\
\hline $10-4-95$ & $\mathrm{n} / \mathrm{r}$ & 4 & $\mathrm{n} / \mathrm{r}$ \\
\hline $3-20-96$ & $n / r$ & $\mathrm{n} / \mathrm{r}$ & $\mathrm{n} / \mathrm{r}$ \\
\hline $3-20-96$ & $\mathrm{n} / \mathrm{r}$ & $\mathrm{n} / \mathrm{r}$ & $\mathrm{n} / \mathrm{r}$ \\
\hline $8-25-97$ & 32 & 2 & 9 \\
\hline $11-13-97$ & $<10$ & 1 & $<10$ \\
\hline $01-27-98$ & 9 & 2 & $<10$ \\
\hline $5-26-98$ & $<10$ & 2 & $<10$ \\
\hline $6-18-99$ & $<10$ & $<10$ & $<10$ \\
\hline \multicolumn{4}{|c|}{$<5$ - 32 ppm } \\
\hline$\left[\mathrm{H}_{2}\right]_{\text {Average }}$ & & & \\
\hline
\end{tabular}

Note:

$\mathrm{n} / \mathrm{r}=$ not reported 
Table B-18. Tank SX-102 Vapor Sample Results.

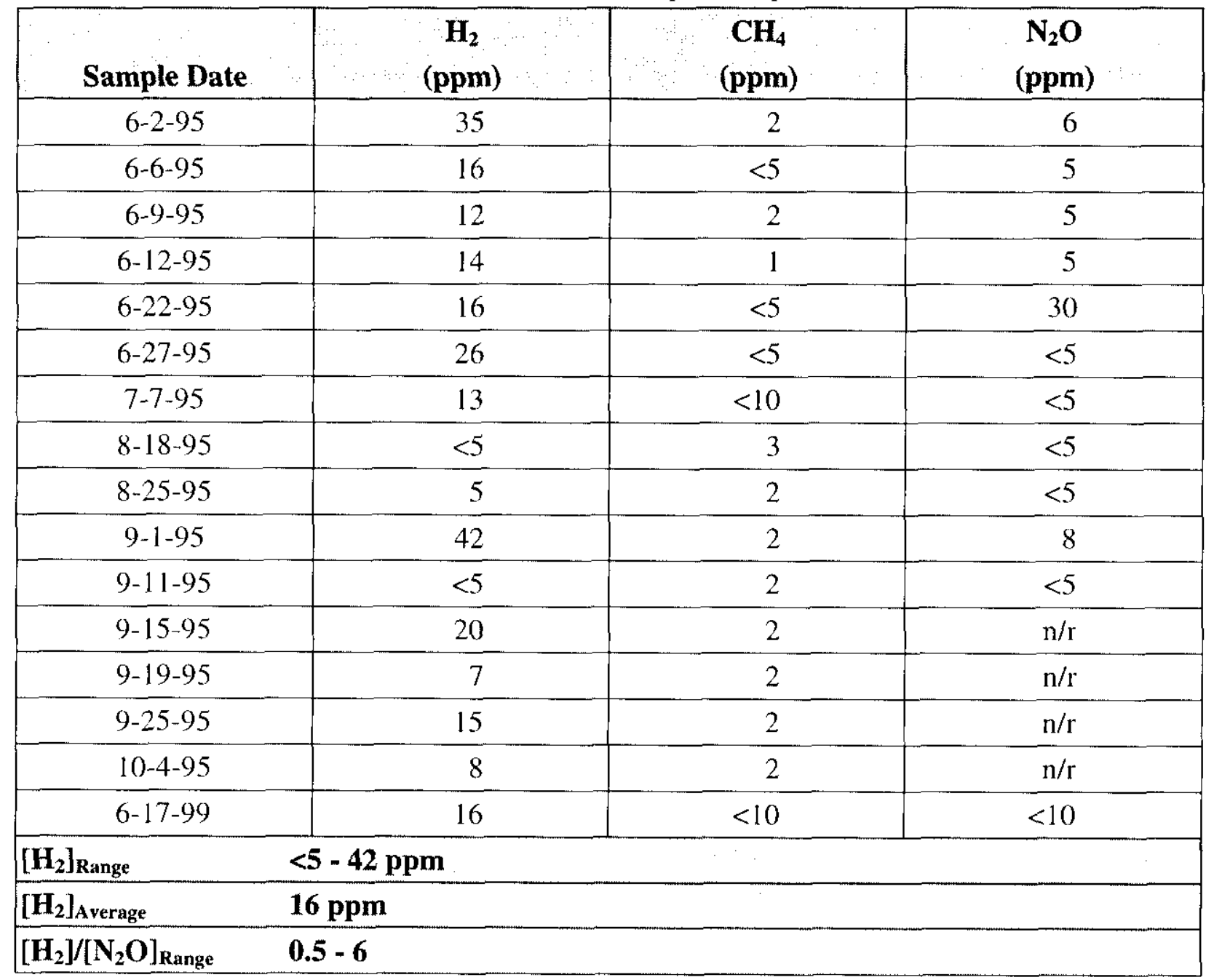

Note:

$\mathrm{n} / \mathrm{r}=$ not reported 
Table B-19. Tank SX-103 Vapor Sample Results.

\begin{tabular}{|c|c|c|c|}
\hline Sample Date & $\begin{array}{c}\mathbf{H}_{\mathbf{2}} \\
(\mathbf{p p m})\end{array}$ & $\begin{array}{c}\mathrm{CH}_{4} \\
(\mathrm{ppm})\end{array}$ & $\begin{array}{c}\mathrm{N}_{2} \mathrm{O} \\
(\mathrm{ppm})\end{array}$ \\
\hline $6-2-95$ & 66 & 2 & 15 \\
\hline 6-6-95 & 32 & 2 & 8 \\
\hline 6-9-95 & 24 & 2 & 8 \\
\hline 6-12-95 & 28 & 2 & 9 \\
\hline 6-22-95 & 31 & $<5$ & 7 \\
\hline $6-27-95$ & 47 & $<5$ & 8 \\
\hline $6-30-95$ & 40 & 10 & 8 \\
\hline $7-7-95$ & 19 & $<10$ & $<5$ \\
\hline 8-18-95 & 19 & 2 & $<5$ \\
\hline $8-25-95$ & 16 & 3 & 5 \\
\hline $9-1-95$ & 63 & $<3$ & 13 \\
\hline $9-11-95$ & 15 & 2 & $<5$ \\
\hline 9-15-95 & 45 & 2 & 8 \\
\hline 9-19-95 & 16 & 2 & $\mathrm{n} / \mathrm{r}$ \\
\hline 9-25-95 & 37 & 2 & $\mathrm{n} / \mathrm{r}$ \\
\hline $10-4-95$ & 23 & 3 & $\mathrm{n} / \mathrm{r}$ \\
\hline 3-20-96 & 6 & $\mathrm{n} / \mathrm{r}$ & $\mathrm{n} / \mathrm{r}$ \\
\hline $3-20-96$ & 10 & $\mathrm{n} / \mathrm{r}$ & $<5$ \\
\hline $5-20-98$ & $<10$ & 2 & $<10$ \\
\hline $8-19-98$ & $<10$ & $<10$ & $<10$ \\
\hline \multicolumn{4}{|c|}{$<10-66 \mathrm{ppm}$} \\
\hline$\left[\mathbf{H}_{2}\right]_{\text {Average }}$ & \multicolumn{3}{|c|}{$28 \mathrm{ppm}$} \\
\hline$\left[\mathrm{H}_{2}\right] /\left[\mathrm{N}_{2} \mathrm{O}\right]_{\text {Range }}$ & \multicolumn{3}{|c|}{$2-6$} \\
\hline
\end{tabular}

Note:

$n / r=$ not reported 
Table B-20. Tank SX-104 Vapor Sample Results.

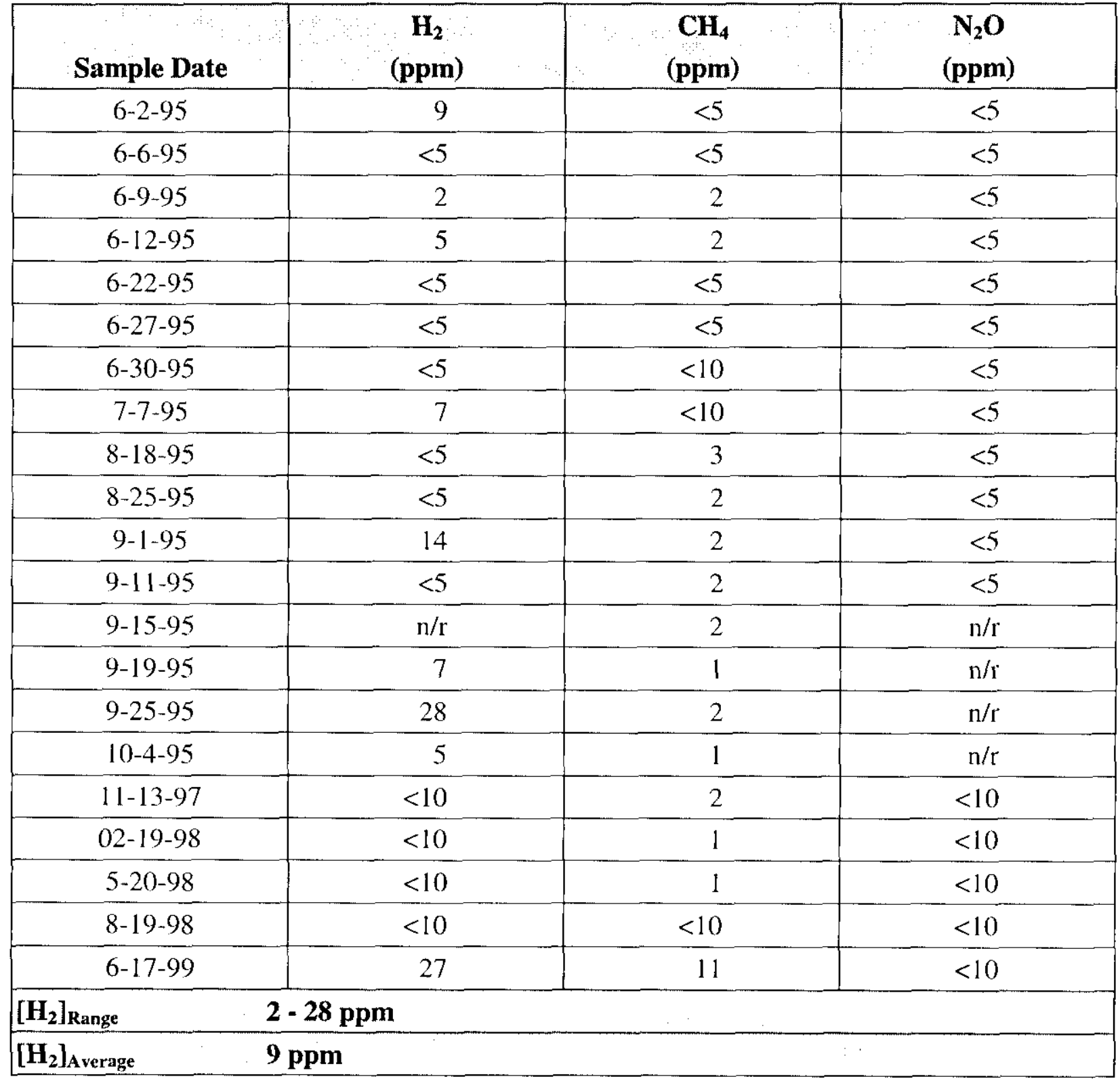

Note:

$\mathrm{n} / \mathrm{r}=$ not reported 
Table B-21. Tank SX-105 Vapor Sample Results.

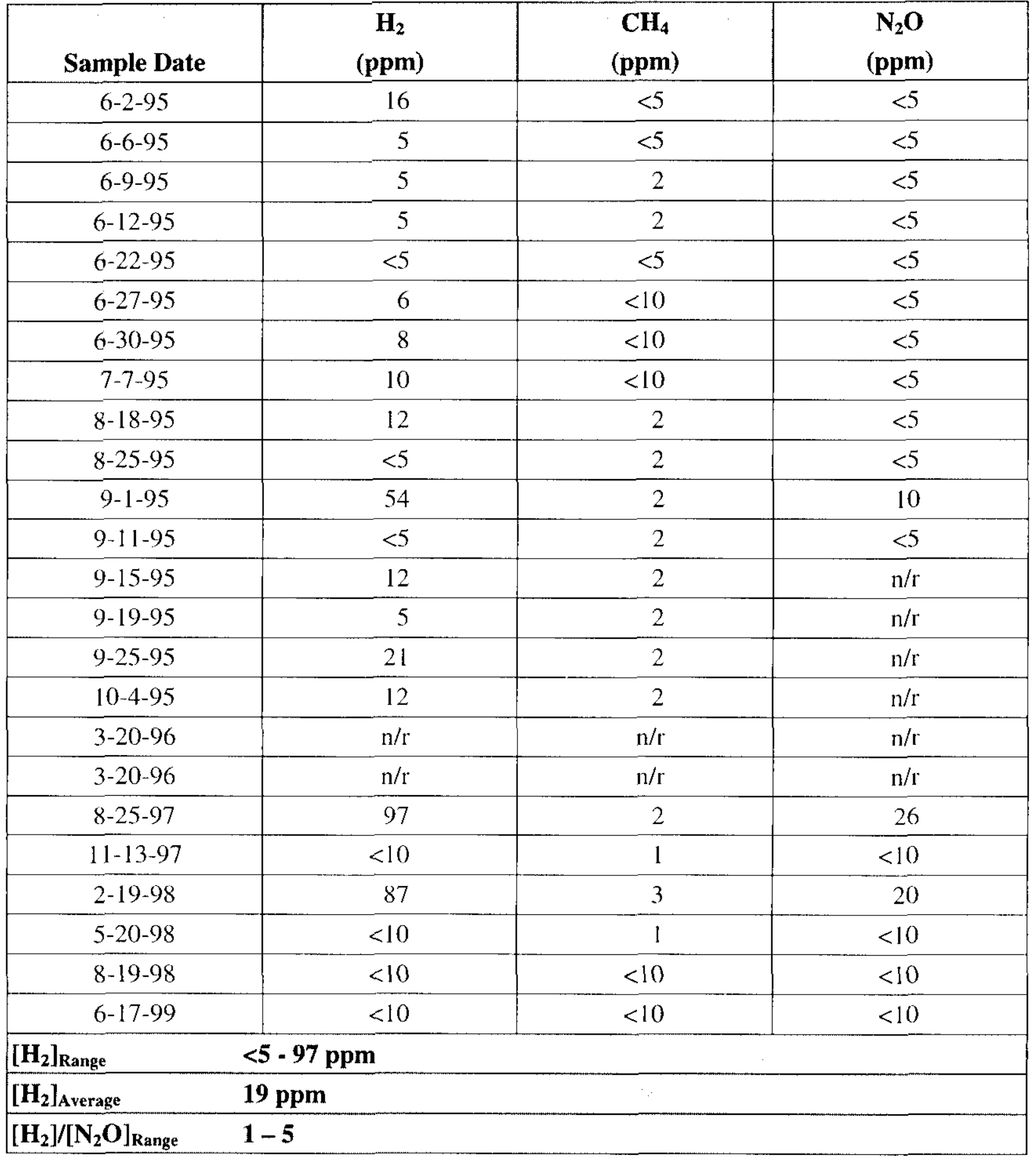

Note:

$\mathrm{n} / \mathrm{r}=$ not reported 
HNF-SD-WM-TI-797 REV 5

Table B-22. Tank SX-106 Vapor Sample Results.

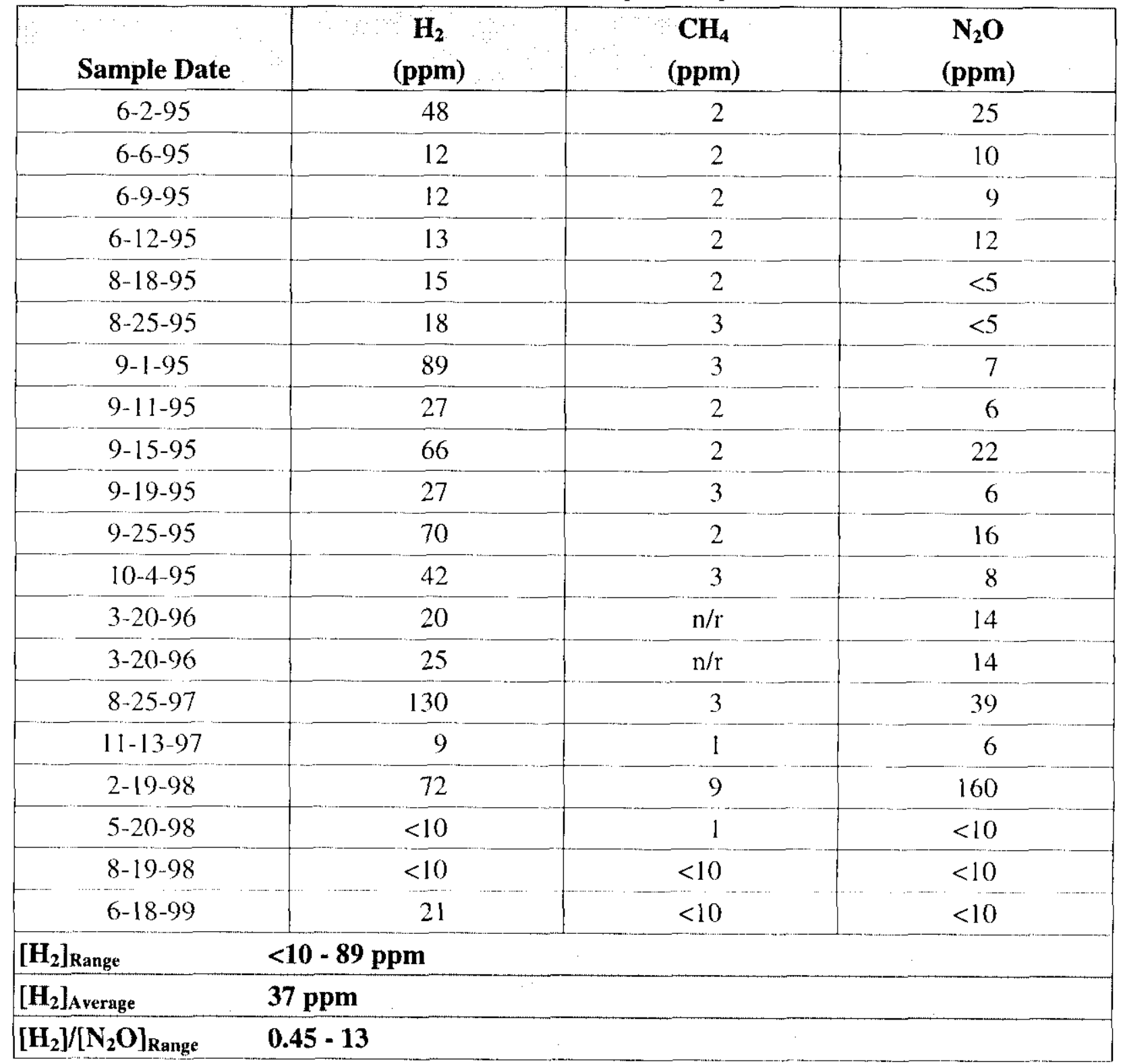

Note:

$n / r=$ not reported 
Table B-23. Tank SX-109 Vapor Sample Results.

\begin{tabular}{|c|c|c|c|}
\hline Sample Date & $\begin{array}{c}\mathbf{H}_{2} \\
(\mathbf{p p m})\end{array}$ & $\begin{array}{c}\mathbf{C H}_{4} \\
(\mathbf{p p m})\end{array}$ & $\begin{array}{c}\mathrm{N}_{2} \mathrm{O} \\
(\mathrm{ppm})\end{array}$ \\
\hline $6-2-95$ & 15 & 2 & 5 \\
\hline $6-6-95$ & 7 & 2 & $<5$ \\
\hline $6-9-95$ & 6 & 2 & $<5$ \\
\hline $6-12-95$ & 8 & $<5$ & 3 \\
\hline $8-25-95$ & $<5$ & 1 & $<5$ \\
\hline $9-1-95$ & 17 & $<5$ & $<5$ \\
\hline $3-20-96$ & 5 & $\mathrm{n} / \mathrm{r}$ & $\mathrm{n} / \mathrm{r}$ \\
\hline $3-20-96$ & 6 & $\mathrm{n} / \mathrm{r}$ & $\mathrm{n} / \mathrm{r}$ \\
\hline $8-25-97$ & 40 & 2 & 9 \\
\hline $11-13-97$ & $<10$ & 1 & $<10$ \\
\hline $2-19-98$ & 67 & 2 & 14 \\
\hline $5-20-98$ & $<10$ & 1 & $<10$ \\
\hline $8-19-98$ & $<10$ & $<10$ & $<10$ \\
\hline $6-18-99$ & $<10$ & $<10$ & $<10$ \\
\hline$\left[\mathbf{H}_{2}\right]_{\text {Range }}$ & \multicolumn{3}{|c|}{$<5-67 \mathrm{ppm}$} \\
\hline$\left[\mathbf{H}_{2}\right]_{\text {Average }}$ & \multicolumn{3}{|c|}{$15 \mathrm{ppm}$} \\
\hline$\left[\mathrm{H}_{2}\right] /\left[\mathrm{N}_{2} \mathrm{O}\right]_{\text {Range }}$ & \multicolumn{3}{|c|}{$1-5$} \\
\hline
\end{tabular}

Nole:

$n / r=$ not reported 
Table B-24. Tank T-110 Vapor Sample Results.

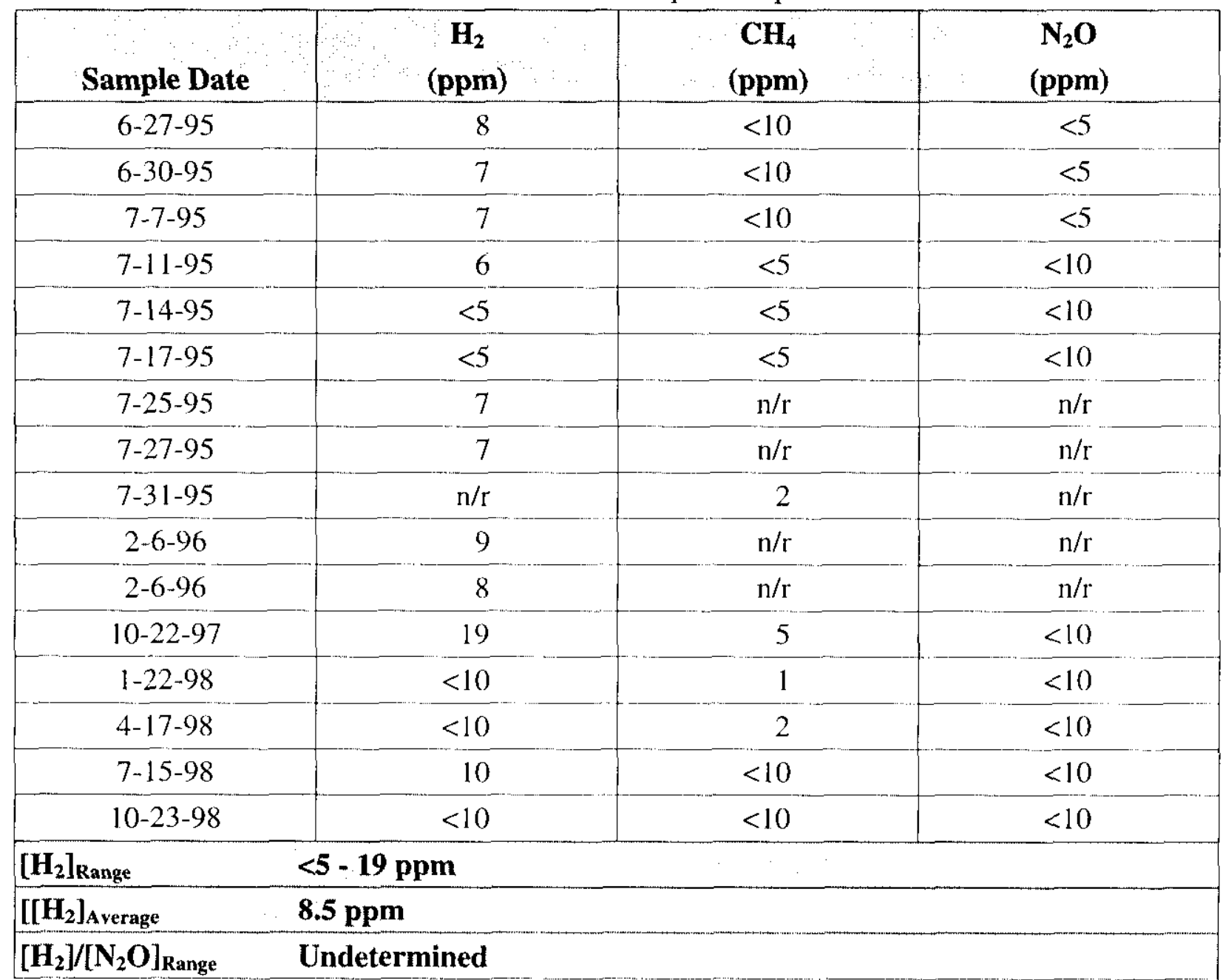

Note:

$\mathrm{n} / \mathrm{r}=$ not reported 
Table B-25. Tank U-102 Vapor Sample Results.

\begin{tabular}{|l|c|c|c|}
\hline Sample Date & $\begin{array}{c}\mathbf{H}_{\mathbf{2}} \\
(\mathbf{p p m})\end{array}$ & $\begin{array}{c}\mathbf{C H}_{\mathbf{4}} \\
(\mathbf{p p m})\end{array}$ & $\begin{array}{c}\mathbf{N}_{\mathbf{2}} \mathbf{O} \\
(\mathbf{p p m})\end{array}$ \\
\hline $7-15-98$ & 395 & $<10$ & 785 \\
\hline $10-23-98$ & 540 & 17 & 1100 \\
\hline$\left[\mathbf{H}_{\mathbf{2}}\right]_{\text {Range }}$ & $\mathbf{3 9 5 - 5 4 0}$ & & \\
\hline$\left[\left[\mathbf{H}_{\mathbf{2}}\right]_{\text {Average }}\right.$ & $\mathbf{4 6 8} \mathbf{~ p p m}$ & & \\
\hline$\left[\mathbf{H}_{\mathbf{2}}\right] /\left[\mathbf{N}_{\mathbf{2}} \mathbf{O}\right]_{\text {Range }}$ & $\mathbf{0 . 4 9 - 0 . 5 0}$ & & \\
\hline
\end{tabular}


Table B-26. Tank U-103 Vapor Sample Results.

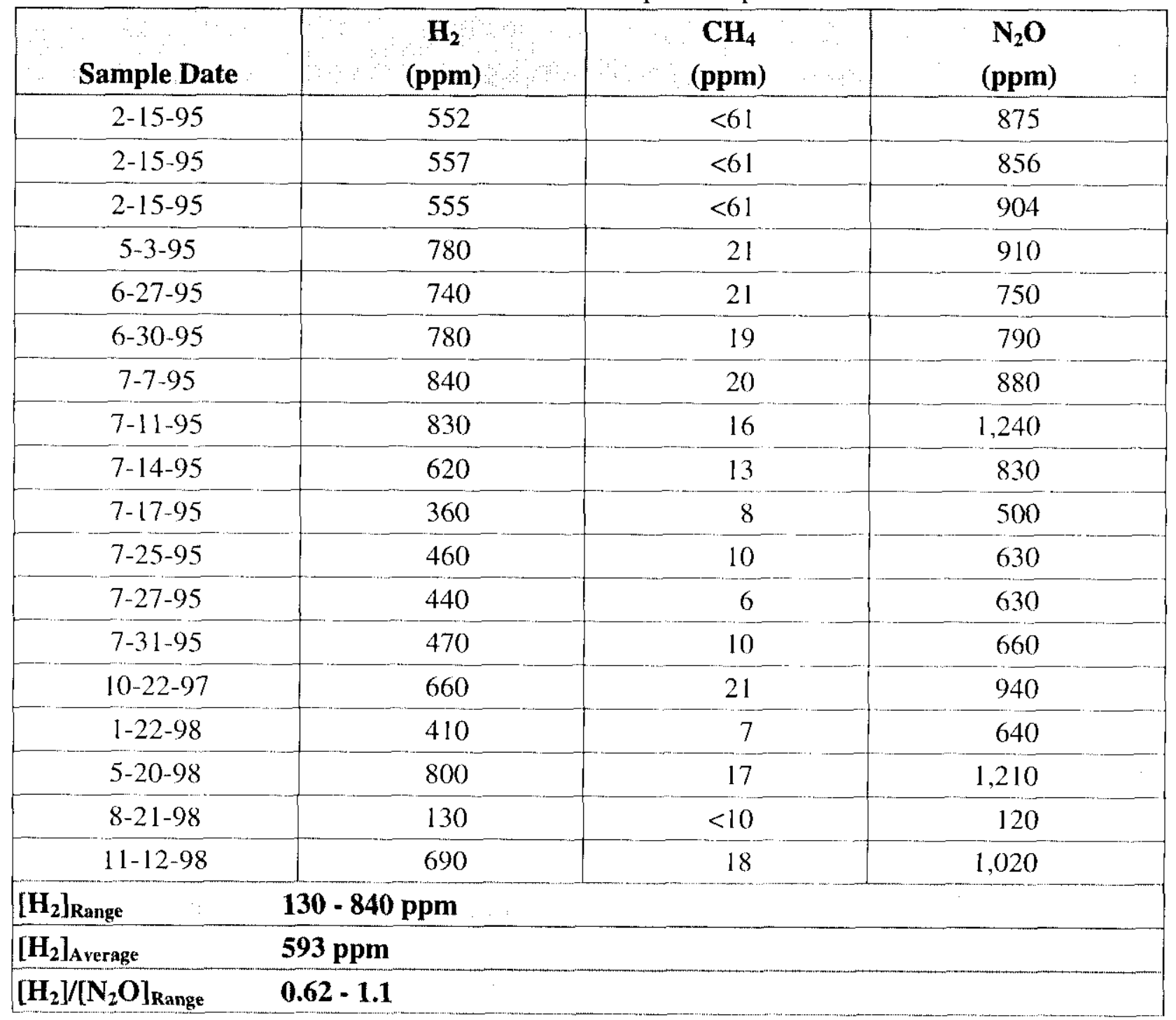


Table B-27. Tank U-105 Vapor Sample Results.

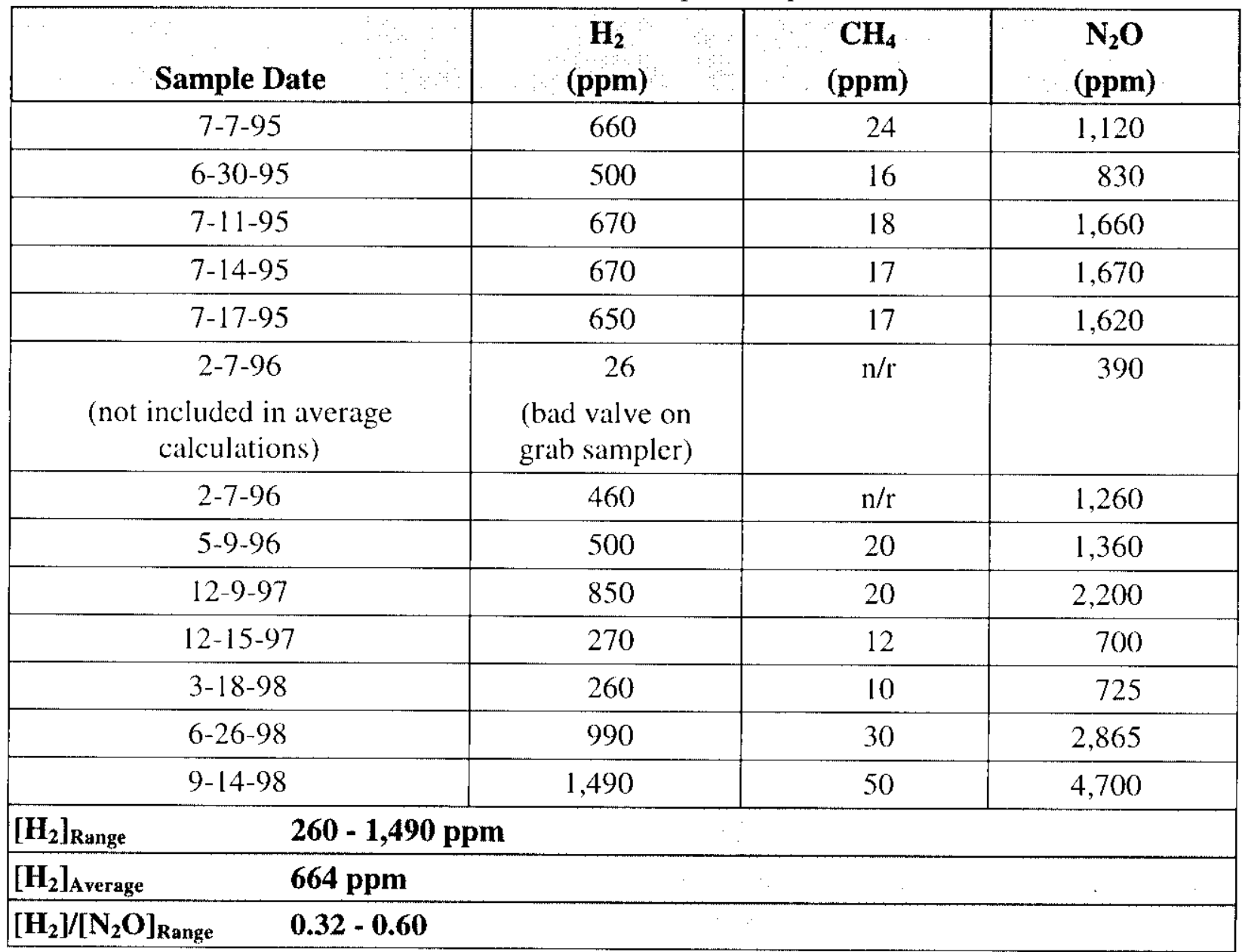

Note:

$$
n / r=\text { not reported }
$$


Table B-28. Tank U-107 Vapor Sample Results.

\begin{tabular}{|c|c|c|c|}
\hline Sample Date & $\begin{array}{c}\mathbf{H}_{2} \\
\text { (ppm) }\end{array}$ & $\begin{array}{r}\mathrm{CH}_{4} \\
(\mathbf{p p m}) \\
\end{array}$ & $\begin{array}{c}\mathrm{N}_{2} \mathrm{O} \\
(\mathrm{ppm})\end{array}$ \\
\hline $2-17-95$ & 496 & $<12$ & 701 \\
\hline $2-17-95$ & 505 & $<12$ & 698 \\
\hline $2-17-95$ & 499 & $<12$ & 703 \\
\hline $6-20-95$ & 280 & $<10$ & 280 \\
\hline $6-30-95$ & 330 & 10 & 350 \\
\hline $7-10-95$ & 340 & 10 & 340 \\
\hline $7-10-95$ & 340 & 10 & 340 \\
\hline $7-11-95$ & 330 & 7 & 510 \\
\hline 7-14-95 & 330 & $<5$ & 490 \\
\hline $7-17-95$ & 310 & 6 & 410 \\
\hline $7-25-95$ & 380 & $n / r$ & 580 \\
\hline $7-27-95$ & 430 & $\mathrm{n} / \mathrm{r}$ & 640 \\
\hline $7-31-95$ & 380 & $\mathrm{n} / \mathrm{r}$ & 520 \\
\hline $2-7-96$ & 260 & $\mathrm{n} / \mathrm{r}$ & 490 \\
\hline $2-7-96$ & 256 & $\mathrm{n} / \mathrm{r}$ & 490 \\
\hline $5-9-96$ & 260 & $<10$ & 430 \\
\hline $5-9-96$ & 260 & $<10$ & 430 \\
\hline $12-15-97$ & 685 & 17 & 1,130 \\
\hline $3-18-98$ & 242 & 7 & 460 \\
\hline $5-20-98$ & 530 & 11 & 1,040 \\
\hline $8-21-98$ & 285 & $<10$ & 520 \\
\hline $11-12-98$ & 690 & 14 & 1,075 \\
\hline \multicolumn{4}{|c|}{$242-690 \mathrm{ppm}$} \\
\hline$\left[\mathrm{H}_{2}\right]_{\text {Average }}$ & \multicolumn{3}{|c|}{$383 \mathrm{ppm}$} \\
\hline$\left[\mathrm{H}_{2}\right] /\left[\mathrm{N}_{2} \mathrm{O}\right]_{\text {Range }}$ & \multicolumn{3}{|c|}{$0.5-1$} \\
\hline
\end{tabular}

Note:

$\mathrm{n} / \mathrm{r}=$ not reported 
Table B-29. Tank U-108 Vapor Sample Results.

\begin{tabular}{|c|c|c|c|}
\hline Sample Date & $\begin{array}{c}\mathbf{H}_{2} \\
\text { (ppm) }\end{array}$ & $\begin{array}{c}\mathrm{CH}_{4} \\
(\mathbf{p p m})\end{array}$ & $\begin{array}{l}\mathrm{N}_{2} \mathbf{O} \\
(\mathrm{ppm})\end{array}$ \\
\hline $6-27-95$ & 430 & 11 & 330 \\
\hline $6-30-95$ & 410 & 8 & 310 \\
\hline $7-7-95$ & 500 & 10 & 360 \\
\hline $7-11-95$ & 470 & 10 & 530 \\
\hline $7-14-95$ & 450 & 8 & 510 \\
\hline $7-17-95$ & 430 & 18 & 450 \\
\hline $9-11-95$ & 490 & 7 & 530 \\
\hline $9-11-95$ & 480 & 8 & 550 \\
\hline $9-18-95$ & $n / r$ & 2 & $\mathrm{n} / \mathrm{r}$ \\
\hline $9-18-95$ & 8 & 1 & $\mathrm{n} / \mathrm{r}$ \\
\hline $2-7-96$ & 296 & $\mathrm{n} / \mathrm{r}$ & 370 \\
\hline $2-7-96$ & 145 & $n / r$ & 120 \\
\hline $5-9-96$ & 520 & 10 & 600 \\
\hline $5-9-96$ & 530 & 20 & 600 \\
\hline $12-15-97$ & 605 & 17 & 745 \\
\hline $3-18-98$ & 435 & 10 & 640 \\
\hline $7-15-98$ & 28 & $<10$ & 20 \\
\hline $10-23-98$ & 470 & 12 & 680 \\
\hline \multicolumn{4}{|c|}{$8-605 \mathrm{ppm}$} \\
\hline$\left[\mathbf{H}_{2}\right]_{\text {Average }}$ & \multicolumn{3}{|c|}{394 ppm } \\
\hline$\left[\mathrm{H}_{2}\right] /\left[\mathrm{N}_{2} \mathrm{O}\right]_{\text {Range }}$ & \multicolumn{3}{|c|}{$0.7-1.4$} \\
\hline
\end{tabular}

Note:

$\mathrm{n} / \mathrm{r}=$ not reported

The samples taken on $9 / 18 / 95$ were not included in the average calculation or range because the values are unusually low. A problem with the sample cylinder is suspected. 
Table B-30. Tank U-109 Vapor Sample Results.

\begin{tabular}{|c|c|c|c|}
\hline Sample Date & $\begin{array}{c}\mathbf{H}_{2} \\
(\mathbf{p p m})\end{array}$ & $\begin{array}{c}\mathbf{C H}_{4} \\
(\mathbf{p p m})\end{array}$ & $\begin{array}{c}\mathrm{N}_{2} \mathrm{O} \\
(\mathrm{ppm})\end{array}$ \\
\hline $7-7-95$ & 460 & 11 & 390 \\
\hline $7-11-95$ & 410 & 8 & 460 \\
\hline $7-14-95$ & 420 & 7 & 520 \\
\hline $7-17-95$ & 390 & 7 & 470 \\
\hline $2-7-96$ & 212 & $\mathrm{n} / \mathrm{r}$ & 273 \\
\hline $2-7-96$ & 215 & $\mathrm{n} / \mathrm{r}$ & 272 \\
\hline $5-9-96$ & 240 & 10 & 29 \\
\hline $5-9-96$ & 240 & 10 & 30 \\
\hline $12-15-97$ & 430 & 14 & 590 \\
\hline $3-18-98$ & 350 & 9 & 610 \\
\hline $5-20-98$ & 530 & 12 & 820 \\
\hline $8-21-98$ & 260 & $<10$ & 255 \\
\hline $11-12-98$ & 625 & 13 & 625 \\
\hline $12-17-98$ & 370 & $<10$ & 605 \\
\hline \multicolumn{4}{|c|}{$212-625 \mathrm{ppm}$} \\
\hline$\left[\mathrm{H}_{2}\right]_{\text {Average }}$ & \multicolumn{3}{|c|}{$368 \mathrm{ppm}$} \\
\hline$\left[\mathrm{H}_{2}\right] /\left[\mathrm{N}_{2} \mathrm{O}\right]_{\text {Range }}$ & \multicolumn{3}{|c|}{$.57-1.2$} \\
\hline
\end{tabular}

Note: $\mathrm{n} / \mathrm{r}=$ not reported

Table B-31. AN Stack Monitor Grab Sample.

\begin{tabular}{|l|c|c|c|c|}
\hline & Date & $\begin{array}{c}\text { H2 } \\
(\mathbf{p p m})\end{array}$ & $\begin{array}{c}\text { N2O } \\
(\mathbf{p p m})\end{array}$ & $\begin{array}{c}\text { CH4 } \\
(\mathbf{p p m})\end{array}$ \\
\hline Steady-state & $1 / 21 / 99$ & 11 & 22 & $<10$ \\
\hline Steady-state & $7 / 19 / 99$ & 19 & 22 & 4 \\
\hline
\end{tabular}


Table B-32. Tank 241-AN-101 Grab Samples.

\begin{tabular}{|l|c|c|c|c|}
\hline & Date & $\begin{array}{c}\text { H2 } \\
(\mathbf{p p m})\end{array}$ & $\begin{array}{c}\text { N2O } \\
(\mathbf{p p m})\end{array}$ & $\begin{array}{c}\text { CH4 } \\
(\mathbf{p p m})\end{array}$ \\
\hline Steady-state & $3 / 19 / 98$ & $<10$ & $<10$ & 1 \\
\hline Steady-state & $4 / 16 / 98$ & $<10$ & $<10$ & 1 \\
\hline Steady-state & $5 / 11 / 98$ & 10 & $<10$ & 2 \\
\hline Steady-state & $6 / 9 / 98$ & $<10$ & $<10$ & $<10$ \\
\hline Steady-state & $7 / 16 / 98$ & $<10$ & $<10$ & $<10$ \\
\hline Steady-state & $8 / 21 / 98$ & $<10$ & $<10$ & $<10$ \\
\hline Steady-state & $9 / 14 / 98$ & $<10$ & $<10$ & $<10$ \\
\hline Stcady-state & $10 / 9 / 98$ & $<10$ & $<10$ & $<10$ \\
\hline
\end{tabular}

Table B-33. Tank 241-AN-103 Grab Samples. (2 sheets)

\begin{tabular}{|l|c|c|c|c|}
\hline & Date & $\begin{array}{c}\text { H2 } \\
(\mathbf{p p m})\end{array}$ & $\begin{array}{c}\text { N2O } \\
(\mathbf{p p m})\end{array}$ & $\begin{array}{c}\text { CH4 } \\
(\mathbf{p p m})\end{array}$ \\
\hline Steady-state & $11 / 2 / 94$ & 77 & $<10$ & $<10$ \\
\hline Steady-state & $11 / 10 / 94$ & 34 & $<10$ & $<10$ \\
\hline Steady-state & $11 / 16 / 94$ & 81 & 6 & $<10$ \\
\hline Steady-state & $11 / 22 / 94$ & 22 & $<5$ & $<10$ \\
\hline Steady-state & $11 / 30 / 94$ & 230 & 14 & $<10$ \\
\hline Steady-state & $12 / 7 / 94$ & 10 & $<5$ & $<10$ \\
\hline Stcady-state & $12 / 14 / 94$ & 25 & $<5$ & $<10$ \\
\hline Steady-state & $12 / 21 / 94$ & 120 & $<10$ & $<10$ \\
\hline Steady-state & $1 / 4 / 95$ & 24 & $<10$ & $<10$ \\
\hline Steady-state & $2 / 29 / 96$ & 15 & $<5$ & $<10$ \\
\hline Steady-state & $2 / 29 / 96$ & 13 & $<5$ & $<10$ \\
\hline Steady-state & $3 / 27 / 96$ & 22 & $<5$ & $<10$ \\
\hline Steady-state & $3 / 27 / 96$ & 23 & $<5$ & $<10$ \\
\hline Steady-state & $5 / 30 / 96$ & $<5$ & $<5$ & $<10$ \\
\hline Steady-state & $5 / 30 / 96$ & $<5$ & $<5$ & $<10$ \\
\hline Steady-state & $9 / 10 / 96$ & 22 & $<10$ & $<10$ \\
\hline Steady-state & $9 / 10 / 96$ & 23 & $<10$ & $<10$ \\
\hline Steady-state & $10 / 23 / 96$ & 37 & $<10$ & $<10$ \\
\hline
\end{tabular}




\section{HNF-SD-WM-TI-797 REV 5}

Table B-33. Tank 241-AN-103 Grab Samples. (2 sheets)

\begin{tabular}{|l|c|c|c|c|}
\hline & Date & $\begin{array}{c}\text { H2 } \\
\text { (ppm) }\end{array}$ & $\begin{array}{c}\text { N2O } \\
\text { (ppm) }\end{array}$ & $\begin{array}{c}\text { CH4 } \\
\text { (ppm) }\end{array}$ \\
\hline Steady-state & $10 / 23 / 96$ & 32 & $<10$ & $<10$ \\
\hline Steady-state & $11 / 7 / 96$ & 21 & $<10$ & $<10$ \\
\hline Steady-state & $11 / 7 / 96$ & 19 & $<10$ & $<10$ \\
\hline Steady-state & $12 / 19 / 96$ & 18 & $<10$ & $<10$ \\
\hline Steady-state & $12 / 19 / 96$ & 19 & $<10$ & $<10$ \\
\hline Steady-state & $1 / 29 / 97$ & 197 & 19 & $<10$ \\
\hline Steady-state & $1 / 29 / 97$ & 197 & 19 & $<10$ \\
\hline Steady-state & $3 / 12 / 97$ & 20 & $<10$ & $<10$ \\
\hline Steady-state & $3 / 12 / 97$ & 13 & $<10$ & $<10$ \\
\hline GRE & $8 / 23 / 95$ & 800 & 39 & $<10$ \\
\hline Steady-state & $8 / 6 / 97$ & 41 & 6 & 3 \\
\hline Steady-state & $8 / 21 / 97$ & 22 & 4 & 1 \\
\hline Steady-state & $10 / 21 / 97$ & 16 & $<10$ & 3 \\
\hline Steady-state & $11 / 7 / 97$ & 16 & $<10$ & 2 \\
\hline Steady-state & $12 / 16 / 97$ & 11 & $<10$ & 1 \\
\hline Steady-state & $1 / 23 / 98$ & 18 & $<10$ & 2 \\
\hline Steady-state & $2 / 17 / 98$ & 26 & $<10$ & 2 \\
\hline Steady-state & $3 / 19 / 98$ & $<10$ & $<10$ & 2 \\
\hline Steady-state & $4 / 16 / 98$ & $<10$ & $<10$ & 2 \\
\hline Steady-state & $5 / 11 / 98$ & 15 & $<10$ & 2 \\
\hline Steady-state & $6 / 9 / 98$ & $<10$ & $<10$ & $<10$ \\
\hline Steady-state & $7 / 16 / 98$ & 17 & $<10$ & $<10$ \\
\hline Steady-state & $8 / 21 / 98$ & 20 & $<10$ & $<10$ \\
\hline Steady-state & $9 / 14 / 98$ & $<10$ & $<10$ & $<10$ \\
\hline Steady-state & $10 / 9 / 98$ & 16 & $<10$ & $<10$ \\
\hline Steady-state & $1 / 15 / 99$ & 24 & $<10$ & $<10$ \\
\hline Steady-state & $4 / 15 / 99$ & 40 & $<10$ & $<10$ \\
\hline Steady-state & $7 / 19 / 99$ & 12 & $<10$ & 5 \\
\hline & & & & 2 \\
\hline
\end{tabular}




\section{HNF-SD-WM-TI-797 REV 5}

Table B-34. Tank 241-AN-104 Grab Samples. (2 sheets)

\begin{tabular}{|l|c|c|c|c|}
\hline & Date & $\begin{array}{c}\text { H2 } \\
\text { (ppm) }\end{array}$ & $\begin{array}{c}\text { N2O } \\
\text { (ppm) }\end{array}$ & $\begin{array}{c}\text { CH4 } \\
\text { (ppm) }\end{array}$ \\
\hline Steady-state & $11 / 2 / 94$ & 47 & $<10$ & $<10$ \\
\hline Steady-state & $11 / 16 / 94$ & 59 & 7 & $<10$ \\
\hline Steady-state & $11 / 22 / 94$ & 32 & 5 & $<10$ \\
\hline Steady-state & $11 / 30 / 94$ & 67 & 8 & $<10$ \\
\hline Stcady-state & $12 / 7 / 94$ & 52 & 8 & $<10$ \\
\hline Steady-state & $12 / 14 / 94$ & 58 & 10 & $<10$ \\
\hline Steady-state & $12 / 21 / 94$ & 66 & $<10$ & $<10$ \\
\hline Steady-state & $1 / 4 / 95$ & 62 & $<10$ & $<10$ \\
\hline Steady-state & $2 / 29 / 96$ & 27 & $<5$ & $<10$ \\
\hline Steady-state & $2 / 29 / 96$ & 25 & $<5$ & $<10$ \\
\hline Steady-state & $3 / 27 / 96$ & 49 & 8 & $<10$ \\
\hline Steady-state & $3 / 27 / 96$ & 51 & 8 & $<10$ \\
\hline Steady-state & $5 / 30 / 96$ & 20 & $<5$ & $<10$ \\
\hline Steady-state & $5 / 30 / 96$ & 21 & $<5$ & $<10$ \\
\hline Steady-state & $9 / 10 / 96$ & 39 & $<10$ & $<10$ \\
\hline Steady-state & $9 / 10 / 96$ & 35 & $<10$ & $<10$ \\
\hline Steady-state & $10 / 23 / 96$ & 31 & $<10$ & $<10$ \\
\hline Steady-state & $10 / 23 / 96$ & 26 & $<10$ & $<10$ \\
\hline Steady-state & $11 / 7 / 96$ & 13 & $<10$ & $<10$ \\
\hline Steady-state & $11 / 7 / 96$ & 14 & $<10$ & $<10$ \\
\hline GRE & $11 / 9 / 94$ & 154 & 19 & $<10$ \\
\hline Steady-state & $12 / 19 / 96$ & 17 & $<10$ & $<10$ \\
\hline Steady-state & $12 / 19 / 96$ & 19 & $<10$ & $<10$ \\
\hline Steady-state & $1 / 29 / 97$ & 26 & $<10$ & $<10$ \\
\hline Steady-state & $1 / 29 / 97$ & 23 & $<10$ & $<10$ \\
\hline Steady-state & $3 / 12 / 97$ & 14 & $<10$ & $<10$ \\
\hline Steady-state & $3 / 12 / 97$ & 13 & $<10$ & $<10$ \\
\hline Steady-state & $8 / 6 / 97$ & 35 & 7 & 3 \\
\hline Steady-state & $8 / 21 / 97$ & 20 & 5 & 2 \\
\hline
\end{tabular}


HNF-SD-WM-TI-797 REV 5

Table B-34. Tank 241-AN-104 Grab Samples. (2 sheets)

\begin{tabular}{|l|c|c|c|c|}
\hline & Date & $\begin{array}{c}\text { H2 } \\
(\mathbf{p p m})\end{array}$ & $\begin{array}{c}\text { N2O } \\
(\mathbf{p p m})\end{array}$ & $\begin{array}{c}\text { CH4 } \\
\text { (ppm) }\end{array}$ \\
\hline Steady-state & $10 / 21 / 97$ & 15 & $<10$ & 4 \\
\hline Steady-state & $11 / 7 / 97$ & 17 & $<10$ & 2 \\
\hline Stcady-state & $12 / 16 / 97$ & 17 & $<10$ & 1 \\
\hline Steady-state & $1 / 23 / 98$ & 15 & $<10$ & 2 \\
\hline Steady-state & $2 / 17 / 98$ & 11 & $<10$ & 1 \\
\hline Steady-state & $3 / 19 / 98$ & $<10$ & $<10$ & 2 \\
\hline Stcady-state & $4 / 16 / 98$ & 12 & $<10$ & 2 \\
\hline Steady-state & $5 / 11 / 98$ & 13 & $<10$ & 2 \\
\hline Steady-state & $6 / 9 / 98$ & 14 & $<10$ & $<10$ \\
\hline Steady-state & $7 / 16 / 98$ & 13 & $<10$ & $<10$ \\
\hline Stcady-state & $8 / 21 / 98$ & 14 & $<10$ & $<10$ \\
\hline Stcady-state & $9 / 14 / 98$ & $<10$ & $<10$ & $<10$ \\
\hline Steady-state & $10 / 9 / 98$ & 16 & $<10$ & $<10$ \\
\hline
\end{tabular}


Table B-35. Tank 241-AN-105 Grab Samples. (2 sheets)

\begin{tabular}{|c|c|c|c|c|}
\hline . & Date & $\begin{array}{c}\text { H2 } \\
\text { (ppm) }\end{array}$ & $\begin{array}{c}\text { N2O } \\
\text { (ppm) }\end{array}$ & $\begin{array}{r}\text { CH4 } \\
\text { (ppm) }\end{array}$ \\
\hline Steady-state & $11 / 2 / 94$ & 101 & 19 & $<10$ \\
\hline Steady-state & $11 / 9 / 94$ & 220 & 31 & $<10$ \\
\hline Steady-state & $11 / 16 / 94$ & 96 & 20 & $<10$ \\
\hline Steady-state & $11 / 22 / 94$ & 98 & 20 & $<10$ \\
\hline Steady-state & $11 / 30 / 94$ & 114 & 20 & $<10$ \\
\hline Steady-state & $12 / 7 / 94$ & 69 & 14 & $<10$ \\
\hline Steady-state & $12 / 14 / 94$ & 173 & 26 & $<10$ \\
\hline GRE & 8/23/95 (leaky canister) & $<5$ & $<5$ & $<10$ \\
\hline GRE & 8/23/95 (leaky canister) & $<5$ & $<5$ & $<10$ \\
\hline Steady-state & $2 / 29 / 96$ & 40 & 8 & $<10$ \\
\hline Steady-state & $2 / 29 / 96$ & 66 & 11 & $<10$ \\
\hline Steady-state & $3 / 27 / 96$ & 40 & 8 & $<10$ \\
\hline Steady-state & $3 / 27 / 96$ & 59 & 8 & $<10$ \\
\hline Steady-state & $5 / 30 / 96$ & 49 & 10 & $<10$ \\
\hline Steady-state & $5 / 30 / 96$ & 134 & 27 & $<10$ \\
\hline GRE & $5 / 30 / 96$ & 4,200 & 860 & 60 \\
\hline GRE & $5 / 30 / 96$ & 10,700 & 2,000 & 110 \\
\hline Steady-state & $9 / 10 / 96$ & $<5$ & $<10$ & $<10$ \\
\hline Steady-state & $9 / 10 / 96$ & 20 & $<10$ & $<10$ \\
\hline Steady-state & $10 / 23 / 96$ & 23 & $<10$ & $<10$ \\
\hline Steady-state & $10 / 23 / 96$ & 15 & $<10$ & $<10$ \\
\hline Stcady-state & $11 / 7 / 96$ & $<10$ & $<10$ & $<10$ \\
\hline Steady-state & $11 / 7 / 96$ & $<10$ & $<10$ & $<10$ \\
\hline Steady-state & $12 / 19 / 96$ & 15 & $<10$ & $<10$ \\
\hline Steady-statc & $12 / 19 / 96$ & 16 & $<10$ & $<10$ \\
\hline Steady-state & $1 / 30 / 97$ & 37 & $<10$ & $<10$ \\
\hline Steady-state & $1 / 30 / 97$ & 37 & $<10$ & $<10$ \\
\hline GRE & 4/6/97 (leaky canister) & 180 & 240 & 7 \\
\hline Stcady-state & $8 / 6 / 97$ & 89 & 18 & 3 \\
\hline
\end{tabular}


Table B-35. Tank 241-AN-105 Grab Samples. (2 sheets)

\begin{tabular}{|l|c|c|c|c|}
\hline & Date & H2 & N2O & CH4 \\
$(\mathbf{p p m})$ & $(\mathbf{p p m})$ & 7 & 2 \\
\hline Steady-state & $8 / 21 / 97$ & 20 & $<10$ & 3 \\
\hline Steady-state & $10 / 21 / 97$ & 8 & $<10$ & 2 \\
\hline Steady-state & $11 / 7 / 97$ & 29 & $<10$ & 2 \\
\hline Steady-state & $12 / 16 / 97$ & 13 & 365 & 19 \\
\hline GRE & $8 / 2 / 99$ & 770 & 705 & \\
\hline
\end{tabular}

Table B-36. Tank 241-AN-107 Grab Samples.)

\begin{tabular}{|l|c|c|c|c|}
\hline & Date & $\begin{array}{c}\text { H2 } \\
(\mathbf{p p m})\end{array}$ & $\begin{array}{c}\text { N2O } \\
(\mathbf{p p m})\end{array}$ & $\begin{array}{c}\text { CH4 } \\
\text { (ppm) }\end{array}$ \\
\hline Steady-state & $3 / 19 / 98$ & 35 & 95 & 3 \\
\hline Steady-state & $4 / 16 / 98$ & 32 & 115 & 3 \\
\hline Steady-state & $5 / 18 / 98$ & 20 & 45 & 2 \\
\hline Steady-state & $6 / 9 / 98$ & 17 & 30 & $<10$ \\
\hline Steady-state & $7 / 16 / 98$ & $<10$ & $<10$ & $<10$ \\
\hline Steady-state & $8 / 21 / 98$ & 14 & 70 & $<10$ \\
\hline Steady-state & $9 / 22 / 98$ & 35 & 90 & $<10$ \\
\hline Steady-state & $10 / 9 / 98$ & $<10$ & $<10$ & $<10$ \\
\hline Steady-state & $1 / 21 / 99$ & 35 & 100 & 12 \\
\hline Steady-state & $4 / 15 / 99$ & 26 & 70 & $<10$ \\
\hline
\end{tabular}

Table B-37. AW Stack Monitor Grab Sample.

\begin{tabular}{|l|c|c|c|c|}
\hline & Date & $\begin{array}{c}\text { H2 } \\
(\mathbf{p p m})\end{array}$ & $\begin{array}{c}\text { N2O } \\
(\mathbf{p p m})\end{array}$ & $\begin{array}{c}\text { CH4 } \\
\text { (ppm) }\end{array}$ \\
\hline Steady-state & $2 / 12 / 99$ & $<10$ & $<10$ & $<10$ \\
\hline Steady-state & $8 / 27 / 99$ & 16 & $<10$ & $<10$ \\
\hline
\end{tabular}


Table B-38. Tank 241-AW-101 Grab Samples. (2 sheets)

\begin{tabular}{|c|c|c|c|c|}
\hline & Date & $\begin{array}{c}\mathrm{H} 2 \\
(\mathrm{ppm})\end{array}$ & $\begin{array}{c}\text { N2O } \\
\text { (ppm) }\end{array}$ & $\begin{array}{c}\text { CH4 } \\
(\mathrm{ppm})\end{array}$ \\
\hline Steady-state & $9 / 28 / 94$ & 467 & 8 & $<10$ \\
\hline Steady-state & $9 / 28 / 94$ & 465 & 9 & $<10$ \\
\hline Steady-state & $10 / 27 / 94$ & 240 & $<10$ & $<10$ \\
\hline Steady-state & $11 / 2 / 94$ & 173 & $<10$ & $<10$ \\
\hline Steady-state & $11 / 10 / 94$ & 400 & $<10$ & $<10$ \\
\hline Steady-state & $11 / 16 / 94$ & 380 & 10 & $<10$ \\
\hline Steady-state & $11 / 22 / 94$ & 170 & 5 & $<10$ \\
\hline Steady-state & $12 / 7 / 94$ & 120 & 5 & $<10$ \\
\hline Steady-state & $12 / 14 / 94$ & 260 & 6 & $<10$ \\
\hline Steady-state & $12 / 21 / 94$ & 400 & 8 & $<10$ \\
\hline Steady-state & $12 / 8 / 95$ & 220 & $<10$ & $<10$ \\
\hline Steady-state & $12 / 8 / 95$ & 230 & $<10$ & $<10$ \\
\hline Steady-state & $9 / 4 / 96$ & 62 & $<5$ & $<10$ \\
\hline Steady-state & $9 / 4 / 96$ & 47 & $<5$ & $<10$ \\
\hline Steady-state & $10 / 21 / 96$ & 30 & $<10$ & $<10$ \\
\hline Steady-state & $10 / 21 / 96$ & 22 & $<10$ & $<10$ \\
\hline Steady-statc & $12 / 12 / 96$ & 39 & $<10$ & $<10$ \\
\hline Steady-state & $12 / 12 / 96$ & 38 & $<10$ & $<10$ \\
\hline Steady-state & $1 / 29 / 97$ & 34 & $<10$ & $<10$ \\
\hline Steady-state & $1 / 29 / 97$ & 35 & $<10$ & $<10$ \\
\hline Steady-state & $3 / 12 / 97$ & 20 & $<10$ & $<10$ \\
\hline Steady-state & $3 / 12 / 97$ & 23 & $<10$ & $<10$ \\
\hline Steady-state & $7 / 13 / 97$ & 20 & $<10$ & $<10$ \\
\hline Steady-state & $7 / 13 / 97$ & $<10$ & $<10$ & $<10$ \\
\hline GRE & 10/6/94 (leaky canister) & 12 & 5 & $<10$ \\
\hline GRE & 10/6/94 (leaky canister) & 13 & 5 & $<10$ \\
\hline GRE & $10 / 21 / 94$ & 2,960 & 94 & 31 \\
\hline GRE & $10 / 21 / 94$ & 2,980 & 93 & 30 \\
\hline GRE & $11 / 30 / 94$ & 910 & 31 & $<10$ \\
\hline
\end{tabular}


Table B-38. Tank 241-AW-101 Grab Samples. (2 sheets)

\begin{tabular}{|l|c|c|c|c|}
\hline & Date & $\begin{array}{c}\text { H2 } \\
(\mathbf{p p m})\end{array}$ & $\begin{array}{c}\text { N2O } \\
(\mathbf{p p m})\end{array}$ & $\begin{array}{c}\text { CH4 } \\
(\mathbf{p p m})\end{array}$ \\
\hline GRE & $8 / 2 / 95$ & 2,850 & 46 & 25 \\
\hline GRE & $8 / 2 / 95$ & 2,850 & 47 & 23 \\
\hline Steady-state & $8 / 21 / 97$ & 14 & $<10$ & 1 \\
\hline Steady-state & $10 / 21 / 97$ & 12 & $<10$ & 2 \\
\hline Steady-state & $11 / 7 / 97$ & 19 & $<10$ & 1 \\
\hline Steady-state & $12 / 16 / 97$ & 41 & $<10$ & 2 \\
\hline
\end{tabular}

Table B-39. Tank 241-AY-102 Grab Samples.

\begin{tabular}{|l|c|c|c|c|}
\hline & Date & $\begin{array}{c}\text { H2 } \\
(\mathbf{p p m})\end{array}$ & $\begin{array}{c}\text { N2O } \\
(\mathbf{p p m})\end{array}$ & $\begin{array}{c}\text { CH4 } \\
(\mathbf{p p m})\end{array}$ \\
\hline Steady-state & $8 / 6 / 97$ & 18 & $<10$ & 2 \\
\hline Steady-state & $8 / 6 / 97$ & 18 & $<10$ & 2 \\
\hline Steady-state & $8 / 13 / 97$ & 15 & $<10$ & $<10$ \\
\hline Steady-state & $8 / 21 / 97$ & 15 & $<10$ & 1 \\
\hline Steady-state & $11 / 11 / 97$ & 21 & $<10$ & 2 \\
\hline Steady-state & $12 / 16 / 97$ & 20 & $<10$ & 2 \\
\hline Steady-state & $1 / 23 / 98$ & 14 & $<10$ & 1 \\
\hline Steady-state & $2 / 18 / 98$ & $<10$ & $<10$ & 2 \\
\hline Steady-state & $3 / 19 / 98$ & 14 & $<10$ & 2 \\
\hline Steady-state & $4 / 16 / 98$ & 59 & $<10$ & 2 \\
\hline Steady-state & $5 / 21 / 98$ & 57 & $<10$ & $<10$ \\
\hline Steady-state & $6 / 9 / 98$ & 64 & $<10$ & $<10$ \\
\hline Steady-state & $7 / 16 / 98$ & 8 & $<10$ & $<10$ \\
\hline Steady-state & $8 / 21 / 98$ & 73 & $<10$ & $<10$ \\
\hline Steady-state & $10 / 26 / 98$ & 52 & $<10$ & $<10$ \\
\hline Steady-state & $4 / 13 / 99$ & 30 & $<10$ & \\
\hline
\end{tabular}


Table B-40. Tank 241-AZ-101 Grab Samples.

\begin{tabular}{|l|c|c|c|c|}
\hline & Date & $\begin{array}{c}\text { H2 } \\
(\mathbf{p p m})\end{array}$ & $\begin{array}{c}\mathbf{N 2 O} \\
\mathbf{( p p m})\end{array}$ & $\begin{array}{c}\text { CH4 } \\
\mathbf{( p p m})\end{array}$ \\
\hline Steady-state & $8 / 21 / 98$ & 65 & $<10$ & $<10$ \\
\hline Steady-state & $10 / 26 / 98$ & 51 & $<10$ & $<10$ \\
\hline Steady-state & $1 / 21 / 99$ & 37 & $<10$ & $<10$ \\
\hline Steady-state & $5 / 21 / 99$ & 40 & $<10$ & $<10$ \\
\hline Steady-state & $9 / 10 / 99$ & 61 & $<10$ & $<10$ \\
\hline
\end{tabular}

Table B-41. Tank 241-AZ-102 Grab Samples.

\begin{tabular}{|l|c|c|c|c|}
\hline & Date & $\begin{array}{c}\text { H2 } \\
(\mathbf{p p m})\end{array}$ & $\begin{array}{c}\text { N2O } \\
(\mathbf{p p m})\end{array}$ & $\begin{array}{c}\text { CH4 } \\
(\mathbf{p p m})\end{array}$ \\
\hline Steady-state & $11 / 20 / 98$ & 185 & $<10$ & $<10$ \\
\hline Steady-state & $1 / 21 / 99$ & $<10$ & $<10$ & $<10$ \\
\hline Steady-state & $5 / 21 / 99$ & 50 & $<10$ & $<10$ \\
\hline Steady-state & $9 / 10 / 99$ & 95 & $<10$ & $<10$ \\
\hline
\end{tabular}

Table B-42. Tank 241-SY-102 Grab Samples.

\begin{tabular}{|l|c|c|c|c|}
\hline & Date & $\begin{array}{c}\text { H2 } \\
(\mathbf{p p m})\end{array}$ & $\begin{array}{c}\text { N2O } \\
(\mathbf{p p m})\end{array}$ & $\begin{array}{c}\text { CH4 } \\
(\mathbf{p p m})\end{array}$ \\
\hline Steady-state & $3 / 18 / 98$ & $<10$ & $<10$ & 2 \\
\hline Steady-state & $4 / 17 / 98$ & $<10$ & $<10$ & 2 \\
\hline Steady-state & $5 / 21 / 98$ & $<10$ & $<10$ & 2 \\
\hline Steady-state & $6 / 11 / 98$ & $<10$ & $<10$ & $<10$ \\
\hline Steady-state & $7 / 15 / 98$ & $<10$ & $<10$ & $<10$ \\
\hline Steady-state & $8 / 19 / 98$ & $<10$ & $<10$ & $<10$ \\
\hline Steady-state & $9 / 14 / 98$ & $<10$ & $<10$ & $<10$ \\
\hline Steady-state & $10 / 23 / 98$ & $<10$ & $<10$ & $<10$ \\
\hline
\end{tabular}


Table B-43. Tank 241-SY-103 Grab Samples. (2 sheets)

\begin{tabular}{|c|c|c|c|c|}
\hline & Date & $\begin{array}{c}\mathrm{H} 2 \\
\text { (ppm) }\end{array}$ & $\begin{array}{c}\text { N2O } \\
(\mathbf{p p m})\end{array}$ & $\begin{array}{r}\text { CH4 } \\
\text { (ppm) }\end{array}$ \\
\hline Steady-state & $8 / 18 / 94$ & 19 & $<10$ & $<10$ \\
\hline Steady-state & $8 / 18 / 94$ & 19 & $<10$ & $<10$ \\
\hline Steady-state & $8 / 25 / 94$ & 16 & $<10$ & $<10$ \\
\hline Steady-state & $8 / 25 / 94$ & 38 & 18 & $<10$ \\
\hline Steady-state & $9 / 1 / 94$ & 63 & 39 & 11 \\
\hline Steady-state & $9 / 1 / 94$ & 3 & $<10$ & $<10$ \\
\hline Steady-state & $9 / 7 / 94$ & $<40$ & $<10$ & $<10$ \\
\hline Steady-state & $9 / 7 / 94$ & 38 & 32 & $<10$ \\
\hline Steady-state & $9 / 15 / 94$ & 27 & 23 & $<10$ \\
\hline Steady-state & $9 / 15 / 94$ & 15 & $<10$ & $<10$ \\
\hline Steady-state & $9 / 23 / 94$ & 28 & 12 & $<10$ \\
\hline Steady-state & $9 / 23 / 94$ & 48 & 23 & $<10$ \\
\hline Steady-state & $10 / 6 / 94$ & 16 & $<5$ & $<10$ \\
\hline Steady-state & $10 / 6 / 94$ & 22 & 5 & $<10$ \\
\hline Steady-state & $10 / 19 / 94$ & 22 & 4 & $<10$ \\
\hline Steady-state & $10 / 19 / 94$ & 28 & 6 & $<10$ \\
\hline GRE & $3 / 2 / 95$ & 1,070 & 630 & 20 \\
\hline GRE & $3 / 2 / 95$ & 1,440 & 900 & 20 \\
\hline GRE & $8 / 24 / 95$ & 750 & 450 & 12 \\
\hline GRE & $8 / 24 / 95$ & 890 & 540 & 15 \\
\hline GRE & $6 / 7 / 96$ & 1,130 & 860 & 23 \\
\hline GRE & $6 / 7 / 96$ & 1,160 & 860 & 22 \\
\hline GRE & $6 / 7 / 96$ & 1,070 & 800 & 20 \\
\hline GRE & $6 / 7 / 96$ & 360 & 150 & $<10$ \\
\hline GRE & $7 / 15 / 96$ & 1,810 & 1,330 & 40 \\
\hline GRE & $7 / 15 / 96$ & 1,810 & 1,300 & 40 \\
\hline Steady-state & $8 / 25 / 97$ & 25 & 12 & $<10$ \\
\hline Steady-state & $10 / 22 / 97$ & 45 & 22 & 6 \\
\hline Steady-state & $11 / 20 / 97$ & 10 & $<10$ & 1 \\
\hline Steady-state & $12 / 16 / 97$ & 18 & 10 & 2 \\
\hline
\end{tabular}


HNF-SD-WM-TI-797 REV 5

Table B-43. Tank 241-SY-103 Grab Samples. (2 sheets)

\begin{tabular}{|l|c|c|c|c|}
\hline & Date & $\begin{array}{c}\text { H2 } \\
\text { (ppm) }\end{array}$ & $\begin{array}{c}\text { N20 } \\
(\mathbf{p p m})\end{array}$ & $\begin{array}{c}\text { CH4 } \\
\text { (ppm) }\end{array}$ \\
\hline Steady-state & $1 / 22 / 98$ & $<10$ & $<10$ & 2 \\
\hline Steady-state & $2 / 18 / 98$ & $<10$ & $<10$ & 2 \\
\hline Stcady-state & $3 / 18 / 98$ & $<10$ & $<10$ & 2 \\
\hline Steady-state & $4 / 17 / 98$ & $<10$ & $<10$ & 2 \\
\hline Steady-state & $5 / 21 / 98$ & $<10$ & $<10$ & $<10$ \\
\hline Steady-state & $6 / 11 / 98$ & 7 & $<10$ & $<10$ \\
\hline Stcady-state & $7 / 15 / 98$ & 17 & $<10$ & $<10$ \\
\hline Steady-state & $8 / 19 / 98$ & $<10$ & $<10$ & $<10$ \\
\hline Steady-state & $9 / 14 / 98$ & 13 & 200 & $<10$ \\
\hline GRE & $10 / 23 / 98$ & 480 & 10 & $<10$ \\
\hline Steady-state & $4 / 14 / 99$ & 10 & 11 & $<10$ \\
\hline Steady-state & $5 / 14 / 99$ & 25 & 21 & $<$ \\
\hline Steady-state & $8 / 27 / 99$ & 37 & & $<10$ \\
\hline
\end{tabular}


HNF-SD-WM-TI-797 REV 5

\title{
APPENDIX C
}

\section{FLAMMABLE GAS SCREENING FOR THE LOWER FLAMMABILITY LIMIT}

\begin{abstract}
Attachment to Funderburke, W. M., 1996, Transmittal of Defense Nuclear Facilities (DNFSB) Recommendation 93-5, Revision 1, Milestone 5.4.3.5.G [Letter Reporting Completion of Flammable Gas Safety Screening of Remaining Passively Ventilated Single Shell Tanks (SSTs) to Determine if Steady-State Vapors Are Less Than 25 Percent of the Lower Flammability Limit $(L F L)$ I, (letter to S. Marchetti, Fluor Daniel Hanford, Inc., October 24), Duke Engineering \& Services, Inc., Richland, Washington.
\end{abstract}


HNF-SD-WM-TI-797 REV 5

This page intentionally left blank.

C-ii 


\section{RESULTS OF VAPOR PHASE SAMPLING OF THE HANFORD PASSIVELY VENTILATED SINGLE-SHELL TANKS}

All 134 passively ventilated single-shell tanks have had their vapor phase sampled for flammable gas either by use of the vapor sampling system (VSS) truck (Bratzel et al. 1995) or by direct measurement on a stream extracted from the tank's dome space using a combustible gas meter (CGM) (Grigsby and Leach 1996). The results of this sampling for each tank are presented in the attached table. The table lists each tank, the date the tank was sampled, the type of sampling preformed and the resulting percentage of the lower flammability limit obtained.

The tank that showed the highest percentage of the lower flammability limit (LFL) is tank 241-C-103. The result reported for this tank is only $13 \%$ of the LFL, well below the action limit of $25 \%$ of the LFL. This tank has a floating organic layer on its surface and is expected to have relatively higher concentrations of both flammable organic vapors and hydrogen. The next highest tank was tank $241-\mathrm{S}-101$ at $7 \%$ of the LFL. Of the 134 tanks sampled only 27 showed flammable gas concentrations above $1 \%$ of the LFL.

The purpose of this sampling is to understand the steady state concentration of flammable gas in these tanks under normal operating conditions. There was no attempt made to sample during periods of restricted passive ventilation or gas release events. While these conditions may occur and would result in elevated flammable gas conditions in the tank, it is important to understand that the normal condition for the dome space is nonflammable even in tanks that only experience passive ventilation.

\section{References:}

Bratzel, D. R., H. Babad, and J. L. Huckaby, 1995, Headspace Gas and Vapor Characterization Summary for 43 Vapor Program Suspect Tanks, Section 3.2.1 pages 8-9,

WHC-SD-WM-ER-514, Rev. 0, Westinghouse Hanford Company, Richland, Washington.

Grigsby, J. M., and C. E. Leach, 1996, Flammable Gas/Slurry Growth Unreviewed Safety Question: Justification for Continued Operation for the Tank Farms at the Hanford Site, Appendix A Section A4.1, pages A12-A13, WHC-SD-WM-JCO-007, Rev. 0, Westinghouse Hanford Company, Richland, Washington. 
HNF-SD-WM-TI-797 REV 5

\begin{tabular}{|l|l|l|l||}
\hline \multicolumn{1}{||}{ Tank \# } & \multicolumn{1}{|c|}{ Sample Date } & \multicolumn{1}{|c||}{ Sample Type } & $\begin{array}{c}\text { Total LFL } \\
(\%)\end{array}$ \\
\hline SST Palssive & \multicolumn{2}{|l||}{} \\
\hline A-101 & $04 / 09 / 95$ & VSS & 2.5 \\
\hline A-102 & $11 / 10 / 95$ & VSS & 0.93 \\
\hline A-103 & $11 / 09 / 95$ & VSS & 1.38 \\
\hline A-104 & $01 / 1 . / 96$ & CGM & 0 \\
\hline A-105 & $01 / 19 / 96$ & CGM & 0 \\
\hline A-106 & $08 / 12 / 96$ & CGM & 2 \\
\hline AX-101 & $04 / 15 / 95$ & VSS & 0.32 \\
\hline AX-102 & $06 / 28 / 95$ & VSS & 0 \\
\hline AX-103 & $04 / 21 / 95$ & VSS & $<0.31$ \\
\hline AX-104 & $01 / 14 / 96$ & CGM & 0 \\
\hline B-101 & $03 / 26 / 96$ & CGM & 0 \\
\hline B-102 & $04 / 18 / 96$ & VSS & 0 \\
\hline B-103 & $02 / 08 / 95$ & VSS & 0 \\
\hline B-104 & $03 / 26 / 96$ & CGM & 0 \\
\hline B-105 & $06 / 06 / 96$ & CGM & 0 \\
\hline B-106 & $04 / 26 / 96$ & CGM & 0 \\
\hline B-107 & $06 / 06 / 96$ & CGM & 2 \\
\hline B-108 & $04 / 26 / 96$ & CGM & 0 \\
\hline B-109 & $06 / 12 / 96$ & CGM & 0 \\
\hline B-110 & $04 / 26 / 96$ & CGM & 0 \\
\hline B-111 & $03 / 19 / 96$ & CGM & 0 \\
\hline B-112 & $08 / 30 / 95$ & CGM & 0 \\
\hline B-201 & $06 / 04 / 96$ & CGM & 0 \\
\hline B-202 & $06 / 04 / 96$ & CGM & 0 \\
\hline B-203 & $11 / 20 / 95$ & CGM & 0 \\
\hline B-204 & $04 / 26 / 96$ & CGM & 0 \\
\hline & & & \\
\hline
\end{tabular}


HNF-SD-WM-TI-797 REV 5

\begin{tabular}{||l|l|l|l||}
\hline \multicolumn{1}{|c|}{ Tank \# } & \multicolumn{1}{|c|}{ Sample Date } & \multicolumn{1}{|c||}{ Sample Type } & \multicolumn{1}{|c||}{$\begin{array}{c}\text { Total LFL } \\
(\%)\end{array}$} \\
\hline BX-101 & $04 / 24 / 96$ & CGM & 0 \\
\hline BX-102 & $06 / 24 / 96$ & CGM & 0 \\
\hline BX-103 & $03 / 26 / 96$ & CGM & 0 \\
\hline BX-104 & $12 / 30 / 94$ & VSS & 0.4 \\
\hline BX-105 & $04 / 24 / 96$ & VSS & 0 \\
\hline BX-106 & $12 / 19 / 95$ & CGM & 0 \\
\hline BX-107 & $11 / 17 / 95$ & VSS & 0.1 \\
\hline BX-108 & $08 / 29 / 95$ & CGM & 0 \\
\hline BX-109 & $04 / 24 / 96$ & CGM & 0 \\
\hline BX-110 & $10 / 02 / 95$ & CGM & 0 \\
\hline BX-111 & $04 / 24 / 96$ & CGM & 03 \\
\hline BX-112 & $04 / 16 / 95$ & CGM & 0 \\
\hline BY-101 & $08 / 08 / 96$ & CGM & 0 \\
\hline BY-102 & $11 / 21 / 95$ & VSS & 0.26 \\
\hline BY-103 & $11 / 01 / 94$ & VSS & 0.1 \\
\hline BY-104 & $06 / 24 / 94$ & VSS & 1 \\
\hline BY-105 & $07 / 07 / 94$ & VSS & 0.3 \\
\hline BY-106 & $07 / 08 / 94$ & VSS & 0.2 \\
\hline BY-107 & $10 / 26 / 94$ & VSS & 2.3 \\
\hline BY-108 & $10 / 27 / 94$ & VSS & 3.4 \\
\hline BY-109 & $08 / 08 / 96$ & CGM & 0 \\
\hline BY-110 & $11 / 11 / 94$ & VSS & 0.4 \\
\hline BY-111 & $11 / 16 / 94$ & VSS & 0.2 \\
\hline BY-112 & $11 / 18 / 94$ & VSS & 0.1 \\
\hline C-101 & $09 / 01 / 94$ & VSS & 1.8 \\
\hline C-102 & $08 / 23 / 94$ & VSS & 1.2 \\
\hline C-103 & $05 / 24 / 94$ & VSS & 13 \\
\hline
\end{tabular}


HNF-SD-WM-TI-797 REV 5

\begin{tabular}{||l|l|l|l||}
\hline \multicolumn{1}{|c|}{ Tank \# } & \multicolumn{1}{|c|}{ Sample Date } & Sample Type & $\begin{array}{c}\text { Total LFL } \\
(\%)\end{array}$ \\
\hline C-104 & $03 / 03 / 94$ & VSS & 0.3 \\
\hline C-107 & $09 / 29 / 94$ & VSS & 0.6 \\
\hline C-108 & $08 / 05 / 94$ & VSS & 0 \\
\hline C-109 & $08 / 09 / 94$ & VSS & 0.3 \\
\hline C-110 & $08 / 24 / 94$ & VSS & 0.2 \\
\hline C-111 & $09 / 13 / 94$ & VSS & 0.03 \\
\hline C-112 & $08 / 11 / 94$ & VSS & 0.5 \\
\hline C-201 & $08 / 31 / 95$ & CGM & 0 \\
\hline C-202 & $08 / 31 / 95$ & CGM & 0 \\
\hline C-203 & $08 / 29 / 95$ & CGM & 0 \\
\hline C-204 & $06 / 03 / 96$ & CGM & 0 \\
\hline S-101 & $04 / 03 / 96$ & CGM & 7 \\
\hline S-102 & $03 / 14 / 95$ & CGM & 2 \\
\hline S-103 & $05 / 17 / 96$ & CGM & 0 \\
\hline S-104 & $03 / 19 / 96$ & CGM & 0 \\
\hline S-105 & $12 / 07 / 95$ & VSS & 0.09 \\
\hline S-106 & $05 / 17 / 96$ & CGM & 0 \\
\hline S-107 & $09 / 30 / 95$ & CGM & 4 \\
\hline S-108 & $12 / 06 / 95$ & VSS & 0.09 \\
\hline S-109 & $05 / 17 / 96$ & CGM & 0 \\
\hline S-110 & $12 / 05 / 95$ & VSS & 0.45 \\
\hline S-111 & $03 / 21 / 95$ & VSS & 1.1 \\
\hline S-112 & $07 / 11 / 95$ & VSS & 0.1 \\
\hline SX-113 & $08 / 18 / 95$ & CGM & 0 \\
\hline SX-115 & $03 / 08 / 96$ & CGM & 0 \\
\hline T-101 & $07 / 30 / 96$ & CGM & 0 \\
\hline T-102 & $05 / 09 / 96$ & CGM & 0 \\
\hline & & & \\
\hline & & \\
\hline
\end{tabular}


HNF-SD-WM-TI-797 REV 5

\begin{tabular}{||l|l|l|l||}
\hline \multicolumn{1}{|c|}{ Tank } & \multicolumn{1}{|c|}{ Sample Date } & \multicolumn{1}{|c||}{ Sample Type } & \multicolumn{1}{|c||}{$\begin{array}{c}\text { Total LFL } \\
(\%)\end{array}$} \\
\hline T-103 & $02 / 15 / 96$ & CGM & 0 \\
\hline T-104 & $02 / 07 / 96$ & VSS & 0 \\
\hline T-105 & $05 / 09 / 96$ & CGM & 0 \\
\hline T-106 & $05 / 09 / 96$ & CGM & 0 \\
\hline T-107 & $12 / 18 / 95$ & VSS & 0.1 \\
\hline T-108 & $05 / 09 / 96$ & CGM & 0 \\
\hline T-109 & $05 / 09 / 96$ & CGM & 0 \\
\hline T-110 & $08 / 31 / 95$ & VSS & 0.1 \\
\hline T-111 & $12 / 20 / 95$ & VSS & 0.2 \\
\hline T-112 & $05 / 09 / 96$ & CGM & 0 \\
\hline T-201 & $07 / 31 / 96$ & CGM & 0 \\
\hline T-202 & $08 / 09 / 96$ & CGM & 2 \\
\hline T-203 & $03 / 19 / 96$ & CGM & 0 \\
\hline T-204 & $07 / 31 / 96$ & CGM & 0 \\
\hline TX-101 & $06 / 14 / 96$ & CGM & 0 \\
\hline TX-102 & $06 / 20 / 96$ & CGM & 0 \\
\hline TX-103 & $06 / 17 / 96$ & CGM & 0 \\
\hline TX-104 & $07 / 23 / 96$ & CGM & 0 \\
\hline TX-105 & $12 / 21 / 94$ & VSS & 0 \\
\hline TX-106 & $07 / 23 / 96$ & CGM & 0 \\
\hline TX-107 & $01 / 17 / 96$ & CGM & 0 \\
\hline TX-108 & $07 / 17 / 96$ & CGM & 0 \\
\hline TX-109 & $07 / 17 / 96$ & CGM & 1 \\
\hline TX-110 & $07 / 17 / 96$ & CGM & 0 \\
\hline TX-111 & $10 / 12 / 95$ & VSS & 0.78 \\
\hline TX-112 & $07 / 24 / 96$ & CGM & 0 \\
\hline TX-113 & $06 / 18 / 96$ & CGM & 0 \\
\hline & & & \\
\hline
\end{tabular}


HNF-SD-WM-TI-797 REV 5

\begin{tabular}{||l|l|l|l||}
\hline \multicolumn{1}{|c|}{ Tank } & \multicolumn{1}{|c|}{ Sample Date } & \multicolumn{1}{|c|}{ Sample Type } & \multicolumn{1}{|c|}{$\begin{array}{c}\text { Total LFL } \\
(\%)\end{array}$} \\
\hline TX-114 & $06 / 18 / 96$ & CGM & 0 \\
\hline TX-115 & $08 / 01 / 96$ & CGM & 0 \\
\hline TX-116 & $03 / 19 / 96$ & CGM & 0 \\
\hline TX-117 & $03 / 19 / 96$ & CGM & 0 \\
\hline TX-118 & $12 / 16 / 94$ & VSS & 0.3 \\
\hline TY-101 & $04 / 06 / 95$ & VSS & 0 \\
\hline TY-102 & $04 / 05 / 96$ & CGM & 0 \\
\hline TY-103 & $04 / 11 / 95$ & VSS & 0.2 \\
\hline TY-104 & $04 / 27 / 95$ & V55 & 0 \\
\hline TY-105 & $08 / 06 / 96$ & CGM & 2 \\
\hline TY-106 & $08 / 18 / 95$ & CGM & 0 \\
\hline U-101 & $02 / 14 / 96$ & CGM & 1 \\
\hline U-102 & $04 / 30 / 96$ & CGM & 3 \\
\hline U-103 & $02 / 15 / 95$ & V55 & 1.9 \\
\hline U-104 & $05 / 10 / 96$ & CGM & 0 \\
\hline U-105 & $02 / 21 / 95$ & VSS & 0.2 \\
\hline U-106 & $03 / 08 / 95$ & VSS & 1.2 \\
\hline U-107 & $02 / 17 / 95$ & VSS & 1.6 \\
\hline U-108 & $08 / 29 / 95$ & VSS & 1.85 \\
\hline U-109 & $08 / 16 / 95$ & VSS & 2.33 \\
\hline U-110 & $03 / 19 / 96$ & CGM & 2. \\
\hline U-111 & $02 / 28 / 95$ & VSS & 1.1 \\
\hline U-112 & $07 / 03 / 96$ & CGM & 2 \\
\hline U-201 & $08 / 18 / 95$ & CGM & 0 \\
\hline U-202 & $08 / 18 / 95$ & CGM & 0 \\
\hline U-203 & $08 / 09 / 95$ & VSS & 0 \\
\hline U-204 & $08 / 08 / 95$ & VSS & 0 \\
\hline
\end{tabular}

